\title{
Laura Neimane
}

\section{AUGŠŽOKL্A ALVEOLĀRĀ KAULA MORFORADIOLOĢISKAIS IZVĒRTËJUMS PACIENTIEM AR ZOBU IMPLANTĀTIEM}

Promocijas darbs medicīnas doktora zinātniskā grāda iegūšanai Specialitāte - zobārstniecība 


\section{AUGŠŽOKL,A ALVEOLĀRĀ \\ KAULA MORFORADIOLOĢISKAIS \\ IZVĒRTĒJUMS PACIENTIEM \\ AR ZOBU IMPLANTĀTIEM}

Promocijas darbs

medicīnas doktora zinātniskā grāda iegūšanai

Specialitāte - zobārstniecība

Darba zinātniskais vadītājs:

Dr. habil. med. profesors Andrejs Skaǵers

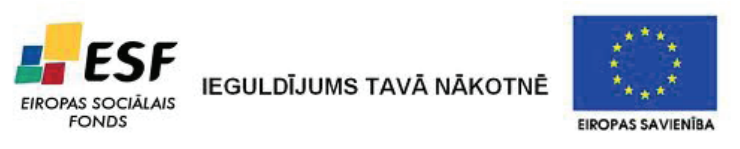

Promocijas darbs veikts ar Eiropas sociālā fonda projekta

"Atbalsts doktorantiem studiju programmas apguvei un zinātniskā grāda ieguvei Rīgas Stradiņa universitātē" finansiālu atbalstu

Rīga, 2014 


\begin{abstract}
ANOTĀCIJA
Augšžokḷa dobuma pamatnes paaugstināšanas operācija pielietojot dažādus kaulu aizvietojošus biomateriālus, lai pastiprinātu un nodrošinātu zobu implantātu stabilitāti, pasaulē tiek plaši lietota. Tomēr iztrūkst plašāks ilgtermiņa pētījums, kurā tiktu analizēts augšžokḷa reziduālā kaula un dobuma stāvoklis pirms un pēc operācijas

Pētījumā tika iekḷauti 59 pacienti, kuriem tika veikta augšžokḷa dobuma paaugstināšanas operācija ar biomateriālu pielietošanu vienā vai abās augšžokḷa pusēs Rīgas Stradiņa Universitātes Stomatologijas Institūta Mutes, sejas un žokḷu ķirurğijas klīnikā. Kopā tika apsekoti 78 augšžokḷa dobumi. Tika izvērtētas pirms operācijas koniskā stara datora tomogrāfijas atrades, veikti augšžokḷa reziduālā alveolārā kaula lineārie un radiologiskā nomelnējuma līmeņa mērījumi, kāa arī augšžokļa dobuma tilpuma mērījumi un radiologiski nosakāmu izmaiņu reǵistrācija. Pēc operācijas izmeklējumos tika veikti gan lineāri, gan radiologiskā nomelnējuma līmeņa mērījumi dažādās vietās augmentētā zonā, gan arī izvērtēti dobuma izmaiņas un noteikts tā tilpums. Atkārtots koniska stara datora tomogrāfijas izmeklējums tika veikts vismaz gadu pēc augmentācijas operācijas. Pēc operācijas tika izvērtēti augmentētās zonas lineārie un nomelnējuma līmen̦a mērījumi, kā arī izmain̦as augšžokḷa dobumā un concha bullosa. Tika apkopoti un analizēti ari pacientu demogrāfiskie dati un to saistības ar iegūtiem mērījumiem.

Pētījumā tika atklāts, ka kaulu aizvietojošie biomateriāli palielina reziduālā alveolārā kaula mineralizāciju ilgtermiņā, bet paša biomateriāla/ audu hibrīda radiolog̣iskais nomelnējuma līmenis ilgtermiṇā samazinās. Š̀̄ saistība tika noteikta radioloǵiski un apstiprina literatūrā aprakstītās histologiiskās atrades. Radiologiiskā nomelnējuma līmeņa vērtības noteikšana implantātu tuvumā ar koniskā stara datora tomogrāfijas metodi var tikt pielietota ņemot vērā metāla artefaktu radītās izmaiņas. Radiologiska augšžokḷa dobuma izvērtēšana gan pirms, gan pēc augšžokḷa dobuma pamatnes paaugstināšanas operācijas ir informatīva un nepieciešama, lai samazinātu pēcoperācijas komplikācijas, kā arī laicīgi novērstu sarežǵījumus.

Promocijas darbam ir 144 lpp, izmantotās literatūras sarakstā iekḷautas 204 publikācijas. Pielikumā pievienotas divu dokumentu kopijas.
\end{abstract}




\section{SUMMARY}

The maxillary sinus floor augmentation using biomaterials of different types for enhancement and enforcement of dental implant stability has been widely used all over the world for a long while. However, literature still does not reveal long term researches where investigation on residual alveolar maxillary bone and maxillary sinus before and after augmentation procedure was done.

Fifty nine patients were selected for the study. Bilateral or unilateral maxillary sinus floor augmentation procedures using different types of biomaterials were performed in these patients. Surgery was done in the Clinic of Maxillofacial Surgery, Riga Stradins University Institute of Stomatology. In total, seventy eight maxillary sinus augmentation procedures were performed; before and after surgery all operation sites and sinuses were investigated radiologically applying cone beam computed tomography. Preoperatively there were detected linear and radiological grey levels of residual alveolar bone and a volume of maxillary sinus was identified. Repeated cone beam computed tomography scanning was done at least one year after surgery. In the second scan the following measurements were taken: linear measurements of augmented area, radiological grey level in several sites, and volume of the sinus. Radiologically detectable changes of sinus mucosa, opening and concha bullosa were detected both in pre and postoperative scans. There also was collected and analysed a demographic data, then a connection between demographic data and radiological results was analysed.

The results revealed that bone substitute materials increase mineralization level of residual alveolar maxillary bone, but the radiological grey level of augmented area decrease over the time. These results were acquired radiologically, and in addition they are supported histologically by the literature data. Correct radiological grey level of augmented area and supporting bone around the dental implants can be detected using cone beam computed tomography method if metal artefact influence is considered. Radiological investigation of maxillary sinus before and after augmentation procedure has informative character. Such information prevents post-operative complications and helps to avoid unexpected situations during the surgical procedure.

The study consists of 144 pages; it includes 204 references. Copies of two documents are added. 


\section{SATURS}

Darbā lietotie saīsinājumi

Ievads

1. Darba mērķis un uzdevumi ................................................................. $\quad 10$

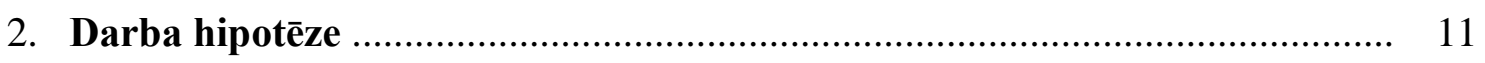

3. Darba zinātniskā novitāte .................................................................... 12

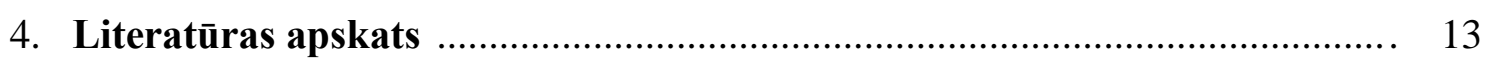

4.1. Augšžokḷa attīstība un anatomija ........................................................... 13

4.2. Augšžokḷa dobums ........................................................................... 14

4.3. Augšžokḷa alveolārais izaugums ............................................................. 17

4.4. Augšžokḷa radioloǵisko izmeklējumu metodes ........................................ 19

4.4.1. Laterālā cefalogrāfija ................................................................ 19

4.4.2. Okcipitomentālā jeb deguna blakusdobuma projekcija .................. 20

4.4.3. PA galvaskausa projekcija ...................................................... 20

4.4.4. Dentālās panorāmas tomogrāfija .................................................. 21

4.4.5. Intraorālās radiogrammas ....................................................... 22

4.5. Koniskā stara datora tomogrāfijas (KSDT) attīstības vēsture ................... 23

4.6. KSDT uzbūve un attēla veidošanas princips ............................................ 23

4.7. KSDT indikācijas un pielietojums mutes, sejas un žokḷ apvidū ............... 26

4.8. KSDT informativitāte augšžokḷa dobuma izmeklēšanā ............................ 27

4.9. Augšžokḷa dobuma pamatnes paaugstināšanas operācija un KSDT nozīme tās plānošanā ........................................................................... 33

4.10. KSDT informativitāte augšžokḷa dobuma pamatnes pēcoperācijas izvēertēšanā ...................................................................................... 35

4.11. Augšžokḷa dobuma pamatnes paaugstināšanas operācijas komplikācijas.. 37 4.11.1. Šneidera membrānas perforācija ................................................ 37

4.11.2. Asiṇošana ........................................................................... 38

4.11.3. Pēcoperācijas augšžokḷa dobuma iekaisums .............................. 38

4.11.4. Augmentētās zonas infekcija .................................................... 39

4.11.5. Oroantrāla fistula .................................................................... 39

4.11.6. Augmentētās zonas un zobu implantātu zaudējums .................... 39

4.12. Augšžokḷa dobuma paaugstināšanas operācijas kontrindikācijas ............ 40

4.13. Kaulu aizvietojošu biomateriālu pielietojums augšžokḷa dobuma pamatnes paaugstināšanai ................................................................... 41 
4.13.1. Autogēnie materiāli .................................................................... 42

4.13.2. Allogēnie materiāli ....................................................................... 43

4.13.3. Ksenogēnie materiāli ................................................................... 43

4.13.4. Sintētiskie materiāli ....................................................................... 44

4.14. Literatūras apskata kopsavilkums ........................................................... 47

5. Materiāli un metodes ............................................................................... 48

5.1. Radiologiskāā izmeklējumu apraksts ........................................................ 49

5.2. Klīnisko un demogrāfisko datu ieguves metode ...................................... 59

5.3. Datu apstrādes statistiskās metodes ............................................................ $\quad 59$

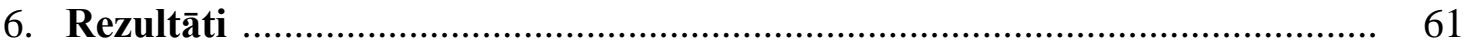

6.1. Demogrāfiskie un klīniskie rezultāti ............................................................ 61

6.2. Preoperatīvo radiologisko izmeklējumu rezultāti ...................................... 65

6.2.1. Augšžokḷa dobuma radiologiskās atrades ..................................... 65

6.2.2. Alveolārā izauguma kaula mērījumu rezultāti ................................ 68

6.3. Postoperatīvo radiologisko izmeklējumu rezultāti ...................................... 71

6.3.1. Augšžokḷa dobuma radiologiskās atrades ...................................... 71

6.3.2. Alveolārā kaula un augmentētās zonas mērījumi .......................... 76

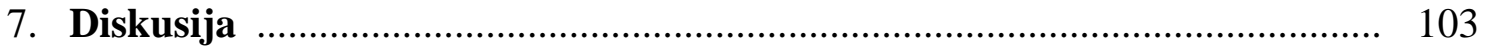

7.1. Augšžokḷa dobuma radioloǵiskās atrades ............................................... 104

7.2. Alveolārā kaula un augšžokḷa dobuma pamatnes augmentētās zonas mērījumi

7.3. Kaula un augmentētās zonas radiologiskā attēla nomelnējuma līmeņa vērtības mērījumi

9. Praktiskās rekomendācijas ....................................................................... 120

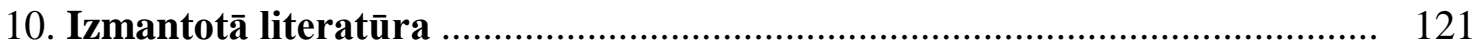

11. Publikācijas un ziņojumi par pētījuma tēmu ................................................ 139

11.1. Publikācijas par pētījuma tēmu................................................................ 139

11.2. Konferenču tēzes par pētījuma tēmu ......................................................... 139

11.3. Ziņojumi kongresos un konferencēs ..................................................... 141

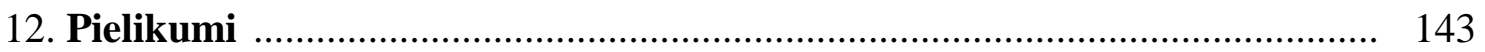

12.1. Uzaicinājuma vēstule pacientiem atkārtotam KSDT izmeklējumam ....... 143

12.2. RSU Ëtikas komitejas lēmums ............................................................ 144 


\section{DARBĀ LIETOTIE SAĪSINĀJUMI}

Saīsinājums

ADPP

ANOVA

AP

ASV

AZ

BAZ

BK

BKK

BKM

DPT

DSDT

DT

Hap

$\mathrm{HU}$

I

$\mathrm{I}_{0}$

K

KSDT

$\log$

$\mathrm{mm}$

$\mathrm{mm}^{3}$

NO

OPG

$\mathrm{p}$

PA

PAZ

PK

\section{Skaidrojums}

augšžokḷa dobuma pamatnes paaugstināšana

dispersijas analīze (analysis of variance, angḷu

val)

apikāli

Amerikas Savienotās Valstis

augmentētā zona

bukāli augmentētā zona

bukāli kauls

bukāli kauls kraniāli

bukāli kaula mala

dentālā panorāmas tomogrāfija

daudzslāņu datora tomogrāfija

datora tomogrāfija

hidroksiapatîts

Haunsfielda vienība

rentgena fotonu plūsmas intensitāte

rentgena fotonu plūsmas intensitāte bez objekta

kauls

koniska stara datora tomogrāfija

logaritms

milimetrs

kubikmilimetri

slāpekḷa monoksīds

ortopantomogramma

būtiskuma (nozīmības) līmenis - varbūtība, ka ir spēkā statistiskajā testā izvirzìtā nulles hipotēze mugurējs - priekšējs

palatināli augmentētā zona

palatināli kauls 
PKK

PKM

RSU

SD

voxel

VV

$\mathrm{X}$

$\mu$

palatināli kauls kraniāli

palatināli kaula mala

Rīgas Stradiṇa Universitāte

standarta deviācija

trīs dimensiju attēla tilpuma vien̄iba

vokseḷa nomelnējuma līmeņa vērtība

rentgena fotonu cel̦a garums caur objektu

lineārais fotonu energiijas vājināšanas koeficients 


\section{IEVADS}

Zobu zudums dažādu etiologisko faktoru ietekmē ir zināms jau kopš pirmo cilvēku laikiem. Kopš seniem laikiem ir pastāvējuši centieni šo problēmu dažādi risināt, jo zobu zaudējums rada estētiskas, funkcionālas, kā arī psiholog̣iskas problēmas. Bezzobu žokḷu gadījumā izmainās cilvēka sejas vaibsti, samazinās sejas augstums un mīksto audu balsts. Funkcionāli cilvēkam ir grūtāk sagremot barību, var rasties traucējumi apakšžokḷa locītavā un mastikatorās muskulatūras pārslodzi.

Alveolārā kaula atrofija pēc zobu zaudējuma norit strauji un neatgriezeniski. Atrofisks alveolārs kauls nenodrošina stabilu balstu arī izņemamām protēzēm, tādēḷ, kad pagājušā gadsimta vidū tika atklāta oseointegrācija, aizsākās arī zobu implantologijas ēra (Block, 1997). Dažkārt alveolārā kaula augšžokḷa mugurējās daḷās atrofija ir ļoti izteikta, un tikai ap $1 \mathrm{~mm}$, plāns kauls šķir mutes dobumu no augšžokl̦a dobuma. Šāds kauls nespēj nodrošināt zobu implantāta primāro stabilitāti. Pagājušā gadsimta septiņdesmitajos gados tika veikta pirmā augšžokḷa dobuma pamatnes paaugstināšanas operācija (Summers, 1998). Augšžokļa dobuma pamatnes augmentācijas zona aizvieto trūkstošo augšžokḷa alveolārā kaula masu. Kopš pirmās augšžokḷa pamatnes paaugstināšanas operācijas ir pagājis ievērojams laiks, tomēr vienprātības par labāko augmentācijai lietojamo biomateriālu, joprojām nav. Par ,zelta standartu” joprojām uzskata autogēnā kaula transplantātu, tomēr arī tā nav ideāla izvēle. Biežāk tomēr tiek lietoti sintētiskie, ksenogēnie vai allogēnie kaulu aizvietojošie biomateriāli viena vai divu etapu ķirurğiskā operācijā ar zoba implantāta ievietošanu.

Pēdējos gados par rekomendētu izmeklējuma metodi pirms augšžokļa dobuma pamatnes paaugstināšanas operācijas ar kaulu aizvietojošiem biomateriāliem tiek uzskatīta trīs dimensiju attēla diagnostika. Samazinātā starojuma dēl vadošā trīs dimensiju radiologiskā izmeklējuma metode ir koniska stara datora tomogrāfija (European Commission, 2012). Pēc operācijas koniska stara datora tomogrāfija rezultātu izvērtēšanā sniedz plašāku pārskatu par operācijas lauku, iespēju izvērtēt augmentētās zonas dimensijas un izmaiņas laika gaitā, kā arī savstarpējo mijiedarbību ar augšžokḷa dobumu.

Pētījumā ir izvērtēti pacientu radiologiskie izmeklējumi pirms un pēc augšžokḷa dobuma pamatnes paaugstināšanas operācijas ar dažādu biomateriālu pielietojumu. Pēc 
operācijas izmeklējums ir veikts vismaz vienu gadu pēc operācijas, nosakot augmentētās zonas dimensijas un radioloǵiskā nomelnējuma līmeņa vērtība. Pētījumā ir izvērtēts operācijas puses augšžokḷa dobuma stāvoklis gan pirms, gan pēc operācijas. Ir radiologiski redzamās patologijas un tilpums. 


\section{DARBA MĒRKGIS UN UZDEVUMI}

\section{Darba mērḳis:}

Radiologiski izvērtēt augšžokḷa struktūras pirms un pēc augšžokḷa dobuma pamatnes paaugstināšanas operācijas ar kaulu aizvietojošiem biomateriāliem ilgtermiṇā.

\section{Darba uzdevumi:}

1. Sagatavot literatūras pārskatu par augšžokḷa dobuma pamatnes operāciju ar kaulu aizvietojošo biomateriālus pielietojumu plānošanu, dažādu materiālu pielietojumu, pēcoperācijas, kā arī radiologisku augšžokḷa dobuma izmaiņu izvērtēšanu.

2. Izvērtēt pacientu preoperatīvos augšžokḷa reziduālā alveolārā kaula lineāros un radiologiiskā nomelnējuma līmeņa vērtības parametrus, kā arī izvērtēt augšžokḷa dobuma stāvokli pirms operācijas radiologiskajos izmeklējumos.

3. Pēc operācijas veikt augmentētās zonas lineāro un radioloǵiskā nomelnējuma vērtības mērījumus, izvērtēt augšžokḷa dobuma stāvokli pēc augšžokḷa dobuma pamatnes paaugstināšanas operācijas veikšanas.

4. Salīdzināt un korelēt pirms un pēc operācijas radioloǵiskajos izmeklējumos iegūtos rezultātus.

5. Salīdzināt dažādo materiālu lietojumu rezultātus.

6. Noteikt biomateriālu ietekmi uz reziduālo kaulu, kā arī biomateriālu/ kaula hibrīda izmaiņas laika gaitā.

7. Noteikt metāla artefaktu ietekmi uz attēlu kroplojumu.

8. Apkopot iegūtos rezultātus un izstrādāt ieteikumus augšžokḷa dobuma pamatnes paaugstināšanas operācijas plānošanā, kā arī pēc operācijas rezultātu radiologiiskajā izvērtēšanā. 


\section{DARBA HIPOTĒZE}

1. Augšžokḷa dobuma pamatnes paaugstināšanas operācija ar kaulu aizvietojošu biomateriālu pielietojumu ilgtermiņā patoloǵiski neietekmē augšžokļa dobuma stāvokli.

2. Kalcija fosfâtu saturošie biomateriāli ilgtermiṇā ietekmē reziduālā alveolārā kaula mineralizāciju.

3. Augmentētā biomateriāla/ audu hibrīda radioloǵiskais nomelnējuma līmenis ilgtermiṇā samazinās.

4. Metāla zobu implantātu klātbūtne rada artefaktus, kas ietekmē koniskā stara datora tomogrāfijas radioloǵisko izmeklējumu attēlu. 


\section{DARBA ZINĀTNISKĀ NOVITĀTE}

1. Pirmo reizi Latvijā tika veikts augšžokḷa dobuma pamatnes paaugstināšanas un zobu implantācijas pacientu ilgtermiņa radiomorfologísks pētījums.

2. Pētījumā kompleksi radiologisiski izvērtēts augšžokḷa reziduālais alveolārais kauls un dobums kā pirms, tā arī pēc augšžokḷa dobuma pamatnes paaugstināšanas operācijas.

3. Radioloǵiski izvērtēta biomateriālu integrācija un savstarpējā mijiedarbība ar pacienta audiem.

4. Radiologiski izvērtētas biomateriāla/ audu hibrīda izmaiņas laika gaitā.

5. Izvērtēta augšžokḷa dobuma pamatnes paaugstināšanas opēracijas ietekme uz augšžokḷa dobuma stāvokli. 


\section{LITERATŪRAS APSKATS}

\subsection{Augšžokl̦a attīstība un anatomija}

Augšžokḷa kaulam ir vairākas funkcijas. Tajā attīstās un pēc tam ar alveolārā izauguma palīdzību stiprinās zobi. Maksilārā kaula palatinālais izaugums veido mutes dobuma augšējo robežu - cietās aukslējas. Tāpat tas veido deguna dobuma grīdu un piedalās deguna dobuma laterālās un augšèjo robežu formēšanā. Maksilārais kauls veido orbītas apakšējo malu un grīdu. Augšžoklī ir ietverts maksilārais dobums, kas ir viens no četriem deguna blakus dobumu pāriem. Abiem maksilārajiem kauliem saplūstot mediāli veidojas sejas vidējā trešdaļa ( $D u$ Tolt, 2003). Augšžokḷa alveolārā kaula attīstība, formēšanās un izmaiņas aug̣̦la attīstības posmā ir tieši saistîta ar maksilārā dobuma izmain̄ām dzīve laikā.

Trešajā un ceturtajā embrioǵenēzes perioda nedệ̄ā pirmā viscerālā loka mugurējā daḷā attīstās divi maksilārā loka aizmetņi. Piektajā embrioǵenēzes nedēḷā no prozencefalona attīstās mediālais un laterālie nazālie izaugumi. Mediālais izaugums aug kaudāli un savienojas ar mediāli un uz priekšu augošiem maksilāriem izaugumiem. Kopā tie veido nepilnīgus mutes dobuma griestus - primārās aukslējas. Septītajā embrioǵenēzes nedēḷā no maksilārajiem procesiem izaug bilaterāli veidojumi, kas apmēram 5 nedēḷas vēlāk saplūst dorsāli no primārām aukslējām, veidojot sekundārās aukslējas (Thilander, 1985; Moore, 1988).

Ap 6.-7. embrioǵenēzes nedēḷ notiek epitēlija sabiezēšanās un ieaugšana primāro žokḷu rajonā. No šì sabiezētā epitēlija attīstās zobu plātnīte, kas rada piena zobu aizmetṇus. Vienlaicīgi noris mezenhimālo audu pārkaulošanās, un var sākt identificēt alveolāro izaugumu (Thilander, 1985).

Cilvēkam piedzimstot, orbītas ir praktiski izveidojušās. Starp tām atrodas deguna dobums, kura pamatne atrodas gandrīz orbītu apakšèjo malu līmenī. Alveolārais izaugums ir grūti diferencējams, un aukslējas ir lēzenas. Augšžokḷa kauls ir pilns ar zobu aizmetņiem, un maksilārie dobumi nav attīstījušies, tomēr ir redzami aptuveni 3-4 mm lieli padziḷinājumi deguna dobuma pamatnē, kas norāda uz to turpmāko attīstības vietu (Thilander, 1985; Moore, 1988; Nanci, 2008). Etmoidālie un maksilārie dobumi, cilvēkam piedzimstot, ir vienīgie deguna blakus dobumi, kas ir nedaudz klīniski diferencējami. 
Dzimšanas brīdī maksilārie dobumi ir pildīti ar šķidrumu (Lawson, 2008; Moore, 1988; Porter, 2002). Pārējie deguna blakus dobumi attīstās cilvēka dzīves laikā (Moore, 1988).

\subsection{Augšžokḷa dobums}

Augšžokḷa dobumi sāk pneimatizēties uzreiz pēc piedzimšanas. Maksilāro dobumu attīstība notiek divos posmos, kas ir tieši saistīti ar zobu šksilšanos. Pirmais augšžokḷa augšanas posms ir līdz 3 gadu vecumam, kad notiek piena zobu šķilšanās (Moore, 1988; Porter, 2002). Otrais posms ir no septiņiem līdz divpadsmit gadiem, kad šķiḷas pastāvīgie zobi. Laika posmā no trešā līdz septītajam dzīves gadam augšžokḷa augšana notiek lēnām. Arī pēc divpadsmitā dzīves gada dobumu augšana ir pakāpeniska, lēna. Augšana turpinās līdz pieauguša cilvēka vecumam (Lawson, 2008). Pateicoties zobu šķilšanās gaitai, alveolārais process kḷūst izteiktāks, un līdztekus aug arī maksilārie dobumi. Augšžokḷa augšana ir komplekss process un notiek visās dimensijās vienlaicīgi (4.1. attēls).

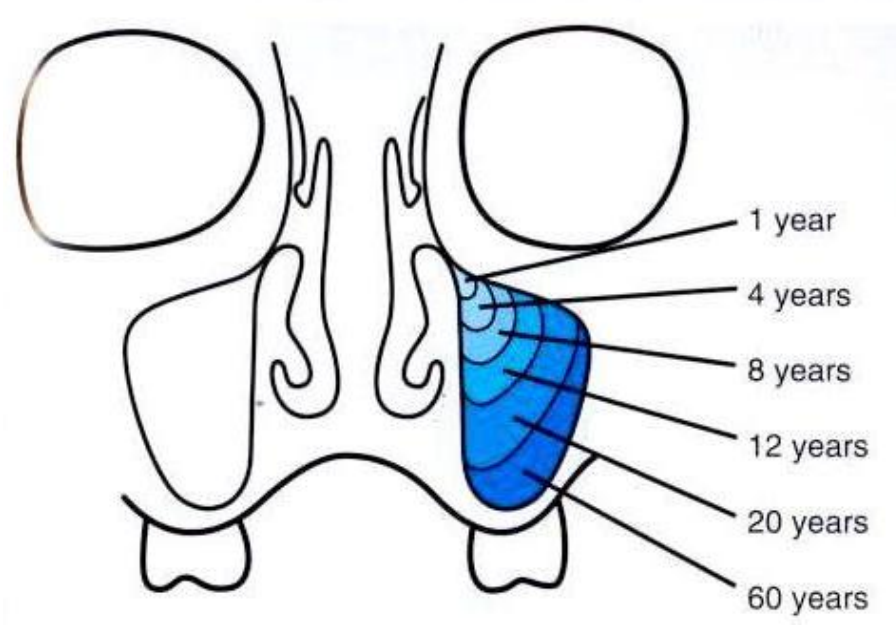

4.1. att. Augšžokḷa dobuma attīstība dzīves laikā (Bagheri, 2012)

Pieaugušam cilvēkam augšžokḷa dobumiem ir piramīdas formas, kuras tilpums ir vidēji 15 mililitri (Gosau, 2009). Augšžokḷa dobumi ir lielākie cilvēka deguna blakus dobumi. Piramīdas pamatni veido deguna dobuma laterāā siena, bet virsotne atrodas pie vaiga kaula izauguma. Dobuma augšējo sienu veido orbīta, kurā atrodas infraorbitālais kanāls. Mugurējo sienu veido plāns kauls, aiz kura atrodas pterigomaksilārā bedre. Priekšèjā siena ir plāns kauls, kur tā plānākā daḷā atrodas virs kanīna zoba. Parasti dobuma 
priekšējā robeža reti kad sniedzas tālāk par pirmo premolāru. Dobuma pamatnes līmenis dzīves laikā ir main̄̄gs, ar tendenci pieaugt. Līdz deviņu gadu vecumam dobuma pamatne atrodas augstāk par deguna dobuma pamatni. Augšžokḷa dobuma pamatne pazeminās vēlākos gados, pateicoties patstāvīgo zobu šķilšanās procesam un dobuma pneimatizācijai. Tie ir divi procesi, kas notiek vienlaicīgi (Lawson, 2008; Sinelnikov, 1996; Porter, 2002). Vidēji pieaugušam cilvēkam dobuma pamatne atrodas $1,5 \mathrm{~cm}$ zem deguna dobuma pamatnes līmeņa (Nimigean, 2008). Maksilāro dobumu pneimatizācijas izmaiņas ir iespējamas visu mūžu. Bieži vien pēc zobu ekstrakcijas maksilārais dobums izvelvējas alveolārā izaugumā - ekstrahēto zobu vietā. Dobuma pneimatizācija alveolārā izaugumā katram indivīdam ir atšksirīga. Citreiz vienam indivīdam pat abu dobumu pneimatizācija pēc zobu zaudēšanas abās augšžokḷa pusēs ir atšksirīga. Pie izteiktas dobuma pneimatizācijas un alveolārā kaula atrofijas robeža starp augšžokḷa dobumu un mutes dobumu var būt tikai $1 \mathrm{~mm}$. To veido tikai kortikālais kauls (Van den Bergh, 2000). Dobuma pneimatizācija ir izteiktāka gadījumos, kad pirms zoba ekstrakcijas dobums lokalizējas tuvu zoba saknēm. Ievērojamāka pneimatizācija ir vērojama arī augšžokḷa otro molāru ekstrakcijas gadījumā un situācijās, kad vienlaicīgi tiek ekstrahēti vairāki zobi (Sharan, 2008).

Ir atklāts, ka dobuma palielināšanās sievietēm notiek līdz 30 gadiem, bet vīriešiem līdz pat 40 gadu vecumam. Pēc tam abiem dzimumiem maksilārā dobuma tilpums samazinās, iespējams, kaula minerālu daudzuma izmaiņu un strukturālu izmaiṇu dēḷ visos kaulos, kas apņem dobumu (Jun, 2005).

Maksilāro dobumu, tāpat kā deguna dobumu, klāj skropstiṇu epitēlijs. Deguna blakusdobumu klājošais epitēlijs ir plānāks par to, kas klāj deguna dobumu. Blakusdobumu klājošās glotādas biezums ir aptuveni 0,3-1 mm, un tā ir mazāk vaskularizēta kā deguna dobuma gḷotāda (Van den Bergh, 2000). Gḷotādā ir dziedzeri, kas ražo gḷotas. Zem epitēlija slāṇa atrodas membrāna, lamina propria un periosts (Mossa - Basha, 2013; Porter, 2002). Visu šo audu kopumu, kas klāj augšžokḷa dobumu, sauc arī par Šneidera membrānu. To 1660. gadā Vitenbergā, Vācijā aprakstīja vācu zinātnieks C.V. Šneiders (Feldmann, 1998). Epitēlija skropstiņas kustas tā, ka glotas tiek virzìtas uz dobuma fiziologisko atveri. No fiziologiskās atveres dobuma saturs nonāk deguna dobuma vidējā ejā, pēc tam deguna dobumā, aizdegunē, rīklē, un pēc tam tas tiek norìts. Līidz ar to ir saprotams, ka papildus atveres, kas izveidojas citur mediālajā sienā, blakus dobumu drenāžu neuzlabo (Mossa Basha, 2013; Porter, 2002).

Hipotēzi par deguna dobuma funkciju pirmo reizi dokumentētā vēsturē ir minējis Hipokrāts 400 gadu pirms mūsu ēras. Viṇš aprakstīja deguna blakus dobumus kā 
rezervuārus, kuros drenējas gl̦otas no smadzenēm. Da Vinči bija pirmais, kurš 1489. gadā attēloja zīmējumos frontālos un maksilāros dobumus (Marquez, 2008). Deguna blakus dobumu funkcijas pilnībā nav izskaidrotas joprojām. Tomēr pastāv vairākas teorijas, kādēl tie ir nepieciešami. Diskusijas turpinās, un tiek veikti pētījumi, lai precizētu to funkcijas.

Literatūrā tiek minētas vairākas iespējamās deguna blakus dobumu funkcijas: ieelpotā gaisa mitrināšana un sasildīšana; ar gaisu pildīti kauli padara galvaskausu vieglāku; balss rezonansei; trieciena amortizācija gan traumas gadījumā, gan mastikatorās slodzes absorbēšanas nolūkāa; sejas veidošana un augšana. Atseviškss pētījums, kurā tika salīdzināti maksilārie dobumu tilpumi pērtiķiem, kas uzturā lieto atšķirīgu pārtiku, noraida hipotēzi, ka maksilārie dobumi kalpotu kā ěšanas slodzes amortizētāji (Rae, 2008). Gan cilvēkiem, gan pērtiķiem ir konstatēts, ka, dz̄̄vojot aukstākā klimatā, maksilāro dobumu tilpums ir mazāks (Rae, 2008). 1994. gadā Lundbergs un līdzautori atklāja, ka deguna un blakus dobumu gḷotādas šūnas spēj ražot slāpekḷa monoksīdu - NO. Atšķirībā no citām epitēlija šūnām, kas ražo NO iekaisumu gadījumos, deguna blakus dobumus klājošais epitēlijs to producē veseliem subjektiem. Arī jaundzimušo izelpotajā gaisā ir konstatēts liels daudzums slāpekḷa monoksīda. Savukārt - sinusīta pacientiem NO līmenis ir ļoti zems. Pētījumos ir pierādīts, ka slāpekḷa monoksīds nelielās devās $\left(100 \cdot 10^{-9}\right)$ ir toksisks baktērijām, vīrusiem un sēnītēm, kas apstiprina hipotēzi, ka viena no deguna blakus dobumu funkcijām ir imunolog̣iska organisma aizsardzība. Sinusā NO koncentrācija var sasniegt pat $30000 \cdot 10^{-9}$, tādēl pastāv teorija, ka slāpekḷa monoksīda ražošana ir sinusa pašsterilizēšanas funkcija. Turklāt NO stimulē skropstiņu kustīgumu. Ja ir skropstiņu primāra diskinēzija, tad NO līmenis ir samazināts (Lundberg, 2008; Marquez, 2008; Porter, 2002). Slāpekḷa monoksīdam piemīt vazodilattatora īpašības. Tā klātbūtne ieelpotā gaisā dilatē plaušu asinsvadus, palielinot skābekḷa cirkulāciju un samazinot plaušu asinsvadu rezistenci. Tas, iespējams, izskaidro, kādēḷ jaundzimušie ir obligāti deguna elpotāji, atšķirīīā no pieaugušajiem, kuri dzīves laikā var mainīt šo ieradumu. Ieelpojot caur muti, netiek ieelpots slāpekḷa monoksīds, kuru ražo deguna un tā blakus dobumu gḷotāda, un tādējādi netiek izmantota tā aerokrīnā īpašība. Mutes elpotāju izelpā NO daudzums ir daudz reiz mazāks kā deguna elpotāju izelpā (Lundberg, 2008). 


\subsection{Augšžokḷa alveolārais izaugums}

Augšžokḷa alveolārais izaugums jeb kauls ir daḷa no augšžokḷa. Cilvēkam piedzimstot, tas ir vāji diferencējams. Pirmajā dz̄ives gadā, kad sāk šķilties pirmie zobi, notiek arī alveolārā izauguma diferenciācija. Alveolārais izaugums pilnībā ir izveidojies pusaudžu vecumā, kad ir izšķ̄ilušies visi pastāvīgie zobi, izņemot trešos molārus. Tā augšana var turpināties arī pēc 16 gadu vecuma. Šajā vecumā turpinās arī sejas attīstība un augšana, kas ap 18 gadiem tuvojas nobeigumam. Alveolārais izaugums palielina augšžokḷa vertikālo dimensiju, tādejādi palielinot sejas vidējās trešdaļas augstumu. Alveolāram izaugumam raksturīga apozicionāla augšana (Thilander, 1985; Moore, 1988). Alveolārais izaugums izveidojas, pateicoties zobu šķilšanās procesam, savukārt nobriest, kad zobi tiek pakḷauti okluzālai slodzei ēšanas laikā. Kad zobi tiek zaudēti, rezorbējas arī alveolārais kauls. Tas liecina, ka zobiem ir svarīga loma alveolārā izauguma attīstībā un saglabāšanā (Avery, 2002).

Alveolāro kaulu veido divas kortikālā kaula plāksnītes, kurām pa vidu ir porainais kauls. Kortikālā kaula biezums dažādos žokḷa apvidos ir atšķirīgs. Alveolārā kaula arhitektūra atšksiras arī starp indivīdiem. Jauniem cilvēkiem kaulā ir atrodami vairāk fibroblastu, osteoblastu un cementoblastu nekā pieaugušajiem. Tas liecina par lielāku aktivitāti un spēju radīt jaunu kaulu (Thilander, 1985).

Dzīves laikā sejas kauli mainās, un tiem līdzi mainās arī mīkstie audi (Shaw, 2007). Mainās arī žokḷu kaulu dimensijas. Žokḷu alveolārais loks iegūst apaḷākas kontūras, un samazinās arī alveolārā kaula augstums (Dager, 2008; Richard, 2009; Kloss, 2006). Pēc zobu zaudējuma alveolārais kauls izmainās. Alveolārais kauls tā rezorbcijas rezultātā pārveidojas par reziduālo alveolāro kaulu. Reziduālā kaula atrofiju var ietekmēt dažādi faktori, piemēram, pacienta vecums, dzimums, hormonālās izmaiņas, minerālu deficīts, nepilnvērtīgs uzturs (Fanghanel, 2006; Kloss, 2006). Reziduālā alveolārā kaula augstums samazinās, un tas veido valni, kam var izšksirt palatinālo, okluzālo un vestibulāro virsmu. Reziduālajam alveolārā izauguma valnim var būt dažādas formas, arī līdz $2 \mathrm{~mm}$ plāna, asmeņa forma, kāda vērojama līdz pat $38 \%$ bezzobu pacientu. Šāda alveolārā izauguma forma nav noderīga protezēšanai, jo pacientam protēžu nēsāšana var būt sāpīga, arī zobu implantātu ievietošanai un dobuma pamatnes paaugstināšanas operācijai. Tāds reziduālais alveolārais kauls ir jāpalielina, lai radītu platāku virsmu. Dažreiz alveolārā izauguma rezorbcija pēc kaula zuduma ir tik izteikta, ka tā palatinālā virsma praktiski nav diferencējama. Alveolārais izaugums saplūst ar cietajām aukslējām bez izteiktas robežas. 
Augšžokḷa alveolārais izaugums atrofējas uz augšu un centra virzienā, tādejādi samazinot sākotnējo alveolārā loka perimetru (Lang, 1995; Pietrokovski, 2007; Kloss, 2006). Augšžokḷa alveolārā kaula atrofija straujāk norit pēc zobu zuduma. Tā ir izteiktāka indivīdiem pēc 40 gadu vecuma, jo vecākiem pacientiem ne vienmēr alveolārais kauls pēc zoba ekstrakcijas sadzīst slēdzot zoba alveolu ar kortikālo kaulu. Attiecīgi slodzei tiek pakḷauts daudz mīkstākais porainais kauls, kura rezorbcija ir vienkāršāka un ātrāka kā kortikālā kaula rezorbcija (Reich, 2011). Augšžokḷa alveolāra izauguma atrofija pēc zobu zaudējuma apgrūtina protezēšanu. Arī implantātu ievietošana bez papildus kaula aizvietojošu biomateriālu ievietošanas, lai paaugstinātu maksilārā dobuma pamatni, bieži vien nav iespējama.

Pētījumos ir pierādīts, ka cilvēka augšžokḷa palatinālā izauguma dimensijas dzīves laikā nemainās, ja nav kādu ārējo faktoru, piemēram, trauma vai audzējs, kas varētu veicināt tā izmaiṇas. Savukārt alveolārā izauguma izmaiṇas dz̄ives laikā ir ievērojamas, un pēc zobu zaudējuma tam ir noteikts, paredzams modelis. Mainās gan tā transversālās, gan vertikālās dimensijas (Cawood, 1988). Lai atvieglotu savstarpējo komunikāciju un ārstēšanas plānošanu, ir izveidota augšžokḷa mugurējās daḷas alveolārā kaula atrofijas klasifikators (4.2. attēls), kur I. klase atbilst normai; II. klase - alveolārais izaugums uzreiz pēc zoba ekstrakcijas; III. klase - noapaļots alveolārais izaugums ar pietiekamu kaula augstumu un platumu; IV. klase - asmens tipa alveolārais kauls; V. klase - nolīdzināts alveolārā izauguma kauls ar nepietiekamu augstumu un platumu; VI. klase - totāli rezorbēts alveolārā izauguma kauls.

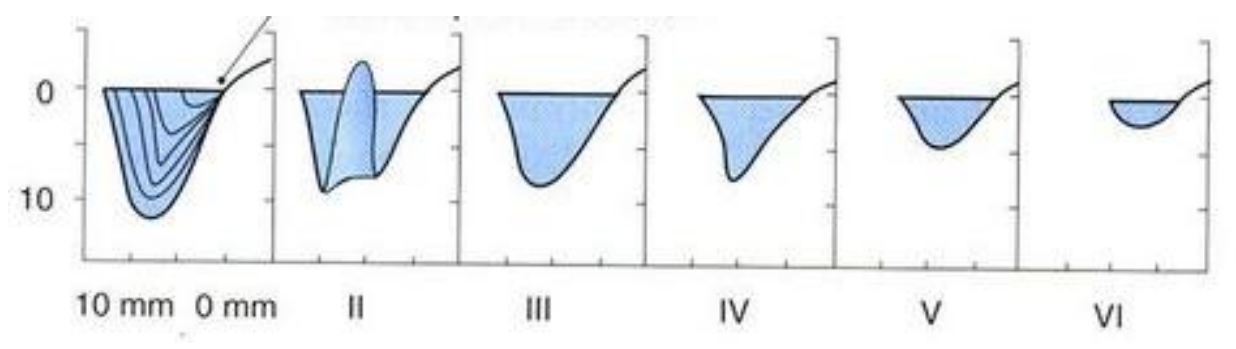

4.2. att. Augšžokḷa mugurējā alveolārā kaula atrofijas klasifikācija (Cawood, 1988) 


\subsection{Augšžokḷa radiologiisko izmeklējumu metodes}

Vēsturiski sejas kauli tika izmeklēti ar konvencionālām ekstraorālām radioloğiskām metodēm. Augšžokḷa dažādas daļas ir iespējams vizualizēt dažādās projekcijās: laterālā cefalometrijāâ, okcipitomentālā jeb deguna blakusdobumu projekcijā, PA (posterior anterior, angḷu val) galvaskausa projekcijā, dentālās panorāmas tomogrāfijā (DPT). Fragmentāri augšžokḷa daḷas redz arī intraorālos dentālos un okluzālos attēlos (White, 2009; Whaites, 2002).

\subsubsection{Laterālā cefalogrāfija}

Laterālā cefalgrāfija galvenokārt tiek lietota ortodontijas vajadzībām, lai diagnosticētu sakodiena un žokḷu skeletālas anomālijas. Laterālās cefalogramās augšžoklim sānskatā redz: cietās aukslējas, zobus, alveolāro izaugumu, dobumus, to mugurējās sienas, augšējo sienu, kas veido orbītas pamatni un daudz citu struktūru. Tomēr jāatceras, ka šajā attēlā abas puses viena otrai uzslāņojas (4.3. attēls).

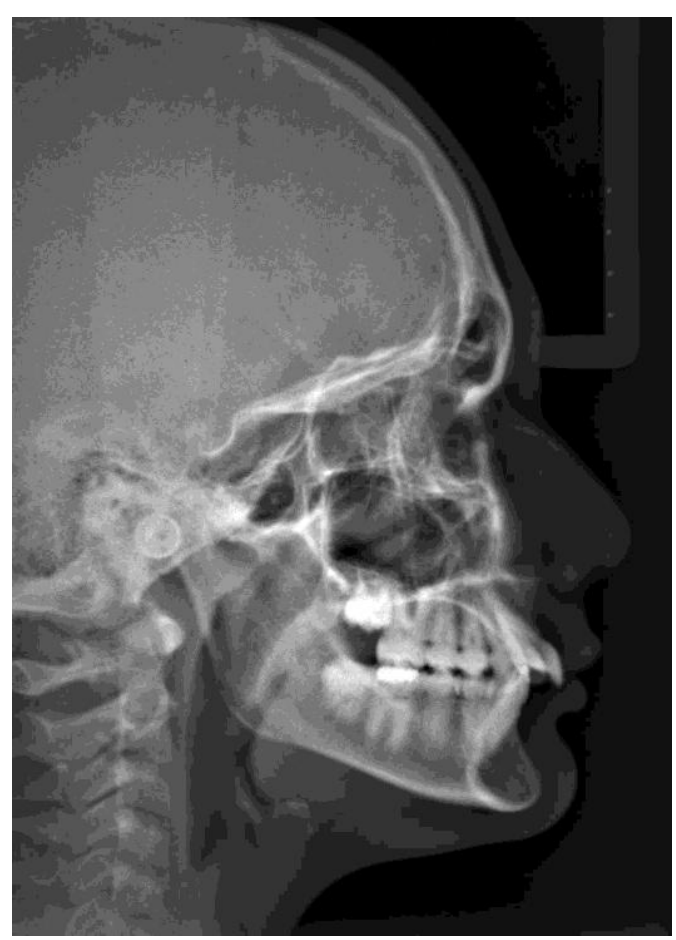

4.3. att. Laterālā cefalogramma 


\subsubsection{Okcipitomentālā jeb deguna blakus dobumu projekcija}

Okcipitomentālā jeb deguna blakus dobumu projekcija parasti tiek lietota, lai diagnosticētu maksilārā dobuma iekaisumu, kā arī traumu gadījumos, kad ir aizdomas par lūzumiem augšžokḷa dobuma apvidū. Attēlos var redzēt esošu šķidruma līmeni, kas atkarībā no anamnēzes datiem, liecina par traumatisku bojājumu vai akūtu strutainu iekaisumu. Šajos attēlos var redzēt visus četrus deguna blakus dobumu pārus, un abas puses ir ērti salīdzināmas. Tomēr precīzu informāciju par deguna blakus dobumu stāvokli ar šo metodi iegūt nevar. Tāpat grūti izvērtējami ir alveolārā kaula izmēri (4.4. attēls).

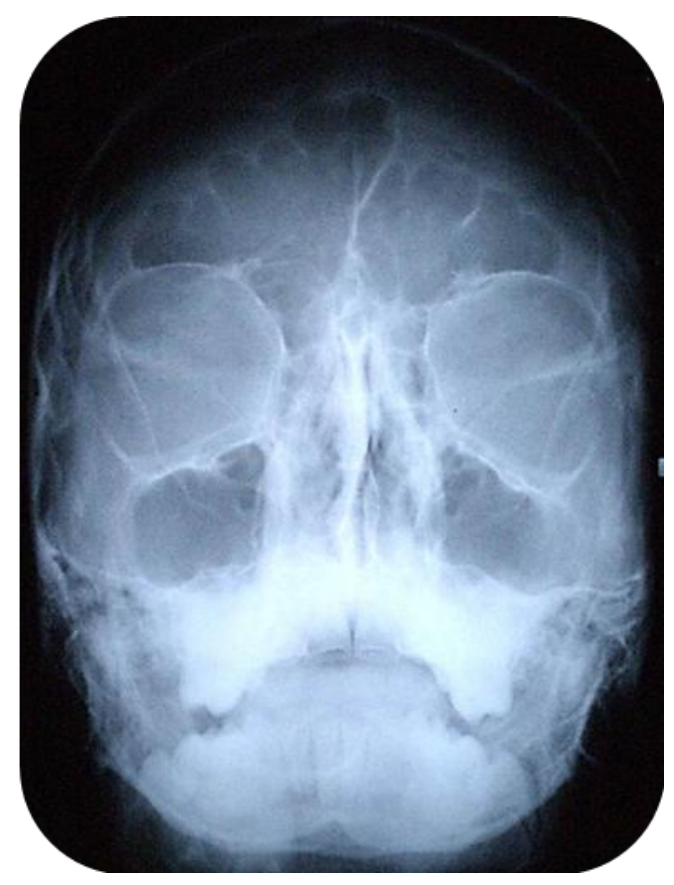

4.4. att. Oksipitomentālā jeb deguna blakusdobumu projekcijas radiogramma

\subsubsection{PA galvaskausa projekcija}

PA (no: posterior - anterior, angḷu val) galvaskausa projekcijā augšžoklis ir vizualizējams, tomēr diagnostiskā informativitāte ir neliela (4.5. attēls). 


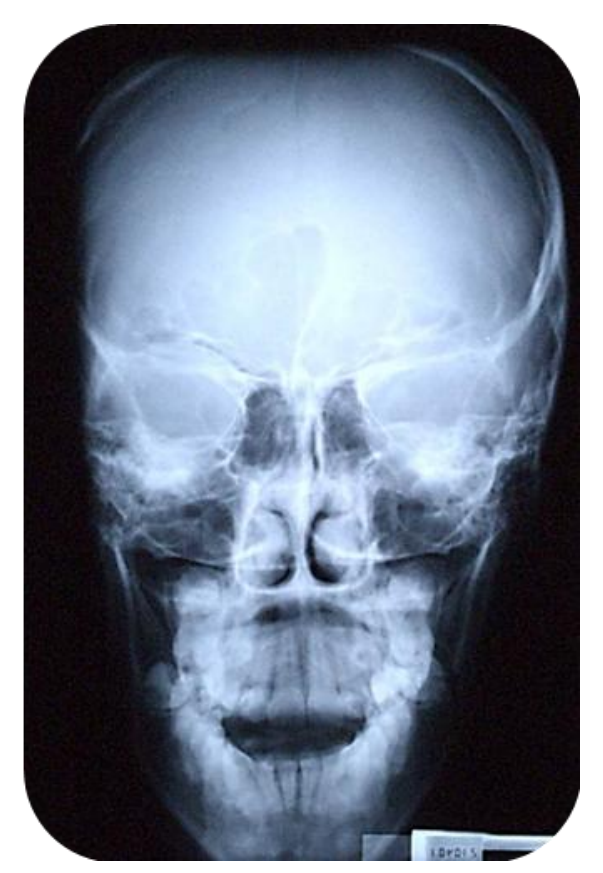

\section{5. att. Galvaskausa radiogramma PA projekcijā}

\subsubsection{Dentālās panorāmas tomogrāfija}

Dentālās panorāmas tomogrāfija, kas vēsturiski tiek sauktu arī par ortopantomogrammu (OPG) (4.6. attēls), ir vizualizējama augšžokḷa dobuma laterālā

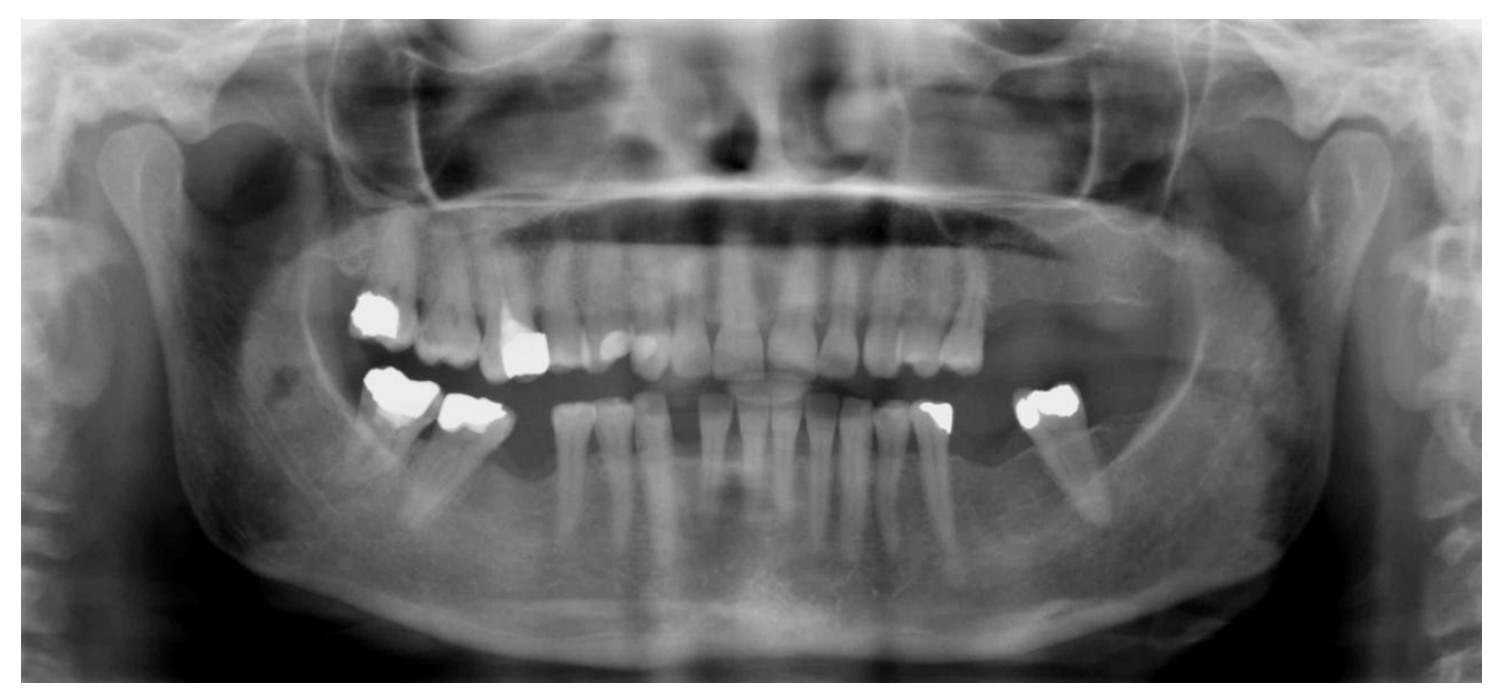

4.6. att. Dentālās panorāmas tomogramma 
un priekšèjā daļas, kas atrodas virs alveolārā izauguma. Arī augšžokḷa alveolārā kaula mugurējās daḷas ir labi vizualizējamas. Precīzu diagnostiku var traucēt pacienta neprecīza pozicionēšana, kā arī citu anatomisku ēnu summas, kas viena otrai uzslāņojas attēla veidošanas procesā. Parasti DPT attēls tiek veidojas tā, ka rodas palielinājums salīdzinājumā ar faktisko izmēru. Katrai iekārtai palielinājums var atšķirties, tomēr vidēji tas ir 1:1,3. Mūsdienās, kad ir pieejami digitālie DPT, iekārtu ir iespējams kalibrēt tā, lai palielinājuma nebūtu. Dentālās panorāmas attēli vēl nesen tika plaši lietoti implantācijas un augšžokḷa dobumu pamatnes paaugstināšanas operāciju plānošanā. Tomēr vairāki autori norāda, ka, plānojot šīs operācijas ar trīs dimensiju attēlu izmeklējumu palīdzību, komplikāciju biežums samazinās (Baciut, 2012; Temmerman, 2011). Divdimensiju panorāmas attēla informativitāte atpaliek no trīsdimensiju attēlu diagnostikas (Sharan, 2006).

\subsubsection{Intraorālās radiogrammas}

Intraorālās okluzālās augšžokḷa projekcijās labi vizualizējas cietās aukslējas, tomēr alveolārais izaugums un dobumu vizualizācija ir vispārēja, pārskata veida, un precīzu informāciju par izmēriem nesniedz. Intraorālos periapikālos (4.7. attēls) uzṇēmumos

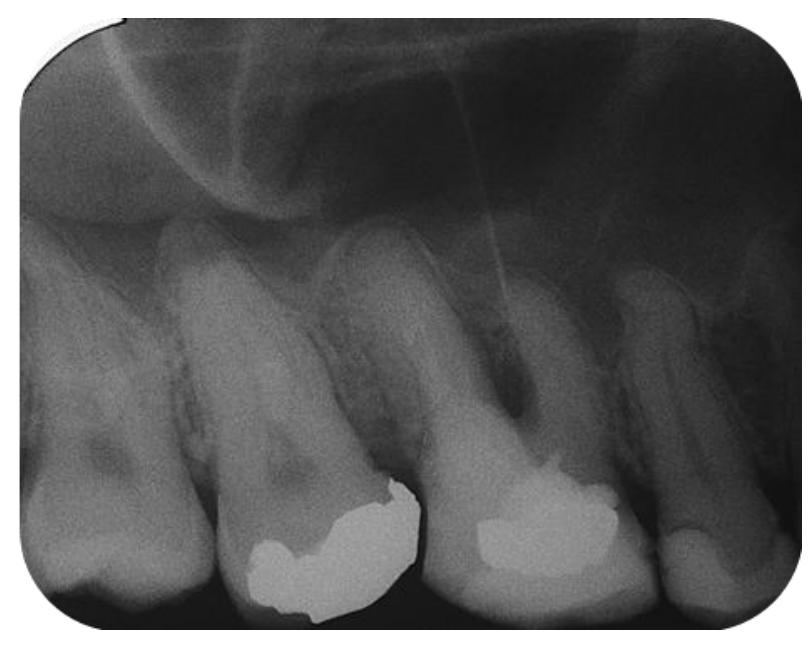

\section{7. att. Intraorāla periapikāla radiogramma}

alveolārā izauguma augstumu var noteikt salīdzinoši precīzi. Tāpat var redzēt izmaiņas, ja tādas ir, izmeklējumā ietvertā maksilārajā dobumā. Tomēr jāatzīmē, ka periapikāliem 
izmeklējumiem, tāpat kā citām konvencionālām metodēm, ir būtisks trūkums. Tajās pacients - telpisks objekts - ir attēlots plaknē. Ir neiespējami izvērtēt pacienta alveolārā kaula platumu, kas ir nepieciešams veiksmīgai zobu implantātu ievietošanai. Svarīgi ir augšžokḷa dobuma stāvokḷa izvērtēšana pirms implantācijas un augšžokḷa pamatnes paaugstināšanas operācijas veiksmīgu rezultātu sasniegšanai (Ozyuvaci, 2005). Tādēḷ 2012. gadā Eiropas Komisija (European Commision, 2012) apstiprināja koniskā stara datora tomogrāfijas (KSDT) lietošanas vadlīnijas, kur noteica, ka vairāku implantātu un maksilārā dobuma pamatnes paaugstināšanas operācijas plānošanas gadījumos tiek rekomendēta trīs dimensiju attēla diagnostika ar mazāko starojuma devu pacientam - KSDT.

\subsection{Koniskā stara datora tomogrāfijas attīstības vēsture}

Koniskā stara datora tomogrāfija arī ir radiolog̣iska izmeklējuma metode. Sākotnēji KSDT tika izveidota angiogrāfijas - kontrastvielas vizualizācijai asinsvados un audos, kā arī radioterapijas vajadzībām. Pirmais KSDT prototips tika radīts 1982. gadā Maijo, ASV (Robb, 1982; Miracle, 2009). Pēc tam KSDT metode ir attīstījusies vairākos virzienos - gan angiogrāfijas, gan staru terapijas, gan mammogrāfijas, gan sejas un žokḷu diagnostiskās radiologijas virzienā. Kaut arī KSDT sistēma pirmo reizi literatūrā tika minēta jau 1982.gadā, sejas un žokḷu diagnostikas vajadzībām to Eiropā sāka lietot 1998. gadā, bet ASV - 2001. gadā (wikipedia.org, 2013). Zinātniskajā literatūrā iekārta pirmo reizi minēta pagājušā gadsimta deviņdesmito gadu beigās. Gandrīz vienlaicīgi literatūrā parādījās divas publikācijas, kurās aprakstītas KSDT iekārtas (Arai, 1999; Mozzo, 1998). Mūsdienās KSDT pielietojums sejas un žokḷu apvidū ir plašs (De Vos, 2009) un bieži vien pārmērīgs, radot bažas par nepamatotu pacientu izmeklēšanu un apstarošanu (European Commission, 2012).

\subsection{KSDT uzbūve un attēla veidošanas princips}

KSDT, tāpat kā visus datora tomogrāfus, veido starojuma avots un starojuma uztvērējs - sensors. Gan starojuma avots, gan sensors atrodas viens otram pretim, un, veicot izmeklējumu, tie rotē ap objektu - pacientu. Sensors uztver rentgena fotonu plūsmu, kas izgājusi caur pacientu. Dažu fotonu enerğija nav mainīta, citiem tā ir mainījusies, citi ir 
novirzīti - izkliedēti, citi absorbēti organismā. Tādas izmaiņas notiek, kad fotoni saskaras ar organisma audiem. Matemātiski tas ir izsakāms šādi:

$$
\mathrm{I}=\mathrm{I}_{0} \exp \left(-\int \mu(\mathrm{x}) \cdot \mathrm{dx}\right)
$$

kur I - rentgena fotonu plūsmas intensitāte, ko uztver sensors

$\mathrm{I}_{0}$ - rentgena fotonu plūsmas intensitāte bez objekta

$\mathrm{x}$ - rentgena fotonu cel̦a garums caur objektu

$\mu$ - lineārais fotonu enerğijas vājināšanas koeficients

Rentgena fotonu plūsmas logaritms izskatās šāds:

$$
-\log \left(\mathrm{I} / \mathrm{I}_{0}\right)
$$

no kura iegūst integrāli, ar ko aprēķina lineāro fotonu enerğijas vājināšanas koeficientu. Šie integrāļi veido izejas datni, kuru ievada attēla rekonstrukcijas programmā, kas veido šķērsgriezuma attēlus. Šķērsgriezuma attēlu veido piksel̦i, kuru vērtība atbilst lineārajam fotonu enerğijas vājināšanas koeficientam. Parasti lineārā fotonu enerǵijas vājināšanas koeficienta vērtība tiek izteikta attiecībā pret ūdens vērtību. Tā starptautiskā mērvienības ir Haunsfîlda vienības - HU (Hounsfield units, ang̣̦u val) (Miracle, 2009; Sukovic, 2004). Precīzs attēla rekonstrukcijas algoritms koniska stara datora tomogrāfijai tika izstrādāts 1984. gadā (Feldkamp, 1984) un tiek lietots joprojām.

KSDT attēla kvalitāte ir atkarīga no sensora, kas uztver informāciju izmeklējuma laikā. KSDT tiek izmantoti plaknes divdimensiju sensori, visbiežāk cietvielu amorfā silīcija digitālais sensors. KSDT pamatprincips ir tāds, ka $360^{\circ}$ apgriezienā ap pacientu ar koniskas formas staru tiek apstarots viss interesējošais lauks. Stars nav nepārtraukta fotonu plūsma. Rentgena fotoni tiek ražoti ar pārtraukumiem, pulsējoši, lai samazinātu pacienta starojuma devu. Turklāt attēla veidošanā nepārtraukts starojums nemaz nav nepieciešams. Rentgena fotonu staram ir staram raksturīga izkliede. Rentgena fotonu izkliede un atstarošana no objektiem rada tā saukto izkliedes starojumu, kas pazemina iegūtā attēla kvalitāti. Lai izkliedes starojums mazāk ietekmētu attēla kvalitāti, iekārtās tiek ievietots režğis, kas aiztur rentgena fotonus ar nepareizu virziena leņķi. Arī rentgena stara filtrācija samazina mazāk intensīvu fotonu nokļū̌šanu attēlu veidojošajā starā. Tādēl jebkurai radioloǵiskai starojuma iekārtai ir stara filtrācija. Svarīgs izkliedes starojuma rašanās avots ir pacients pats. Fotons, virzoties cauri objektam, savā ceļā sastopas ar daudziem dažāda blīvuma audiem, kuru ietekmē fotons zaudē daļu enerğijas, kā arī var tikt novirzịts, atstarots citā, ne centrālā stara, virzienā. Samazinot pacienta izmeklējuma lauku, tiek samazināts stara izmērs, kā arī samazinās stara ceḷā esošo objektu daudzums. Līdz ar to mazinās arī izkliedes starojums un 
tiek iegūts kvalitatīvāks attēls. Kvalitatīva attēla iegūšanas nolūkā tiek rekomendēta pēc iespējas mazāka izmeklējuma lauka izvēle, lai samazinātu izkliedes starojumu un attiecīgi arī pacienta starojuma devu (Miracle, 2009; White, 2009; European Commission, 2012).

KSDT attīstība ir ieguvums gan pacientiem, gan speciālistiem, jo salīdzinājumā ar spirāles datora tomogrāfijas iekārtām, kas ir pirmsākums arī KSDT, š̄i ir lētāka, tai nepieciešama mazāka telpa, tā dod mazāku apstarojuma pacientam un ir vieglāk pieejama. Diagnostiskajā radiologijāa bieži - lai precīzi noteiktu diagnozi - tiek mērīts audu radiologiskais blīvums Haunsfîlda vienībās. Ir izveidota skala, kurā ir attēlots dažādu audu normālais radioloǵiskais blīvums Haunsfîlda vienībās, kas noteikts ar daudzslāņu datora tomogrāfijas iekārtām (DSDT) (4.1. tabula). Ja atšķiras audu normālais blīvums, tad var domāt par patologiju. Tā, piemēram, virsnieru audzēja gadījumā, lai diferencētu starp ļaundabīgu un labdabīgu veidojumu, tiek noteikts audu blīvums Haunsfîlda vienībās datora tomogrāfijas attēlos. Ja blīvums ir mazāks par $10 \mathrm{HU}$, tas nozīmē, ka veidojums satur daudz taukaudus, kas savukārt liecina par labdabīgu procesu virsnieru dziedzerī (Horwich, 2011).

Dažādu audu radioloğiskais blīvums noteikts ar DSDT

\begin{tabular}{|l|c|}
\hline Audi, viela & Haunsfielda vienības (HU) \\
\hline Gaiss & -1000 \\
\hline Plaušas & -500 \\
\hline Tauki & -84 \\
\hline Ũdens & 0 \\
\hline Likvors & 15 \\
\hline Asins & 30 līdz 45 \\
\hline Mīkstie audi & 100 \\
\hline Porainais kauls & 700 \\
\hline Kortikālais kauls & 3000 \\
\hline
\end{tabular}


KSDT attēla veidošanas pamatprincips atškşiras no daudzslāṇu datora tomogrāfijas metodes, tādēl KSDT gadījumos nevar izmantot DSDT noteiktos audu blīvumu. KSDT metode vienādiem audiem var uzrādīt atšksirīgas $\mathrm{HU}$. Līdz ar to diagnostika nav precīza (De Vos, 2009). Audu blīvumu noteikšana ar KSDT nav precīza un salīdzināma ar daudzslāņu datora tomogrāfijas rezultātiem, tomēr iegūtie rezultāti ir ticami un atbilstoši audu histomorfoloǵiskajai analīzei (Soardi, 2012; Cassetta, 2013), un tos var pielietot kaula blīvuma noteikšanā pirms zobu implantācijas (Aranyarachkul, 2005; Lee, 2007). Joprojām tiek izstrādāti algoritmi, lai KSDT blīvuma mērìjumu rezultātus varētu salīdzināt ar DSDT rezultātiem (Vannier, 2003; Swennen, 2006). Kamēr šāds algoritms nav izstrādāts, blīvuma mērījumus, kādus iegūst ar KSDT metodi, ieteicams saukt par radioloğiskā attēla nomelnējuma blīvuma vērtību ar mērvienību VV. Arī radioloǵiskā nomelnējuma līmeņa vērtība, tāpat kā Haunsfîlda vienības, uzrāda izmaiņas attēlā, kas veidojas atkarībā no audu blīvuma, kuriem cauri iet rentgena fotoni. Blīvāki audi aiztur un izmaina rentgena fotonus vairāk, un tas tiek reǵistrēts attēlā.

\subsection{KSDT indikācijas un pielietojums mutes, sejas un žokḷu apvidū}

Koniskā stara datora tomogrāfijas metode ir plaši pielietojama. To lieto strīdīgos, neskaidros endodontiju gadījumos, impaktētu zobu lokalizācijas noteikšanā, temporomandibulārās locītavas kaula struktūru izvērtēšanā, veidojumu diagnostikā, anatomisko struktūru lokalizācijas noteikšanā, ja tās atrodas tuvu operācijas laukam, traumatisku bojājumu gadījumos. Veicot izmeklējumus ar lielo lauka izmēru $(17 \mathrm{~cm})$, attēlā var redzēt visus deguna blakusdobumus, arī mastoīdās šūnas un auss visas struktūras. Lielā lauka izmeklējumi plaši tiek lietoti ortodontisko pacientu izmeklēšanā, ortognātisko operāciju plānošanā, arī operatīvās ārstēšanas plānošanā miega apnojas pacientiem. KSDT attēls ir neizmainīts, līdz ar to var precīzi noteikt kaula biezumu un augstumu implantācijas gadījumos. Implantāciju gadījumos, kad implantātu paredzēts ievietot tuvu mandibulārajam kanālam vai maksilārajam dobumam, attālumu var noteikt precīzi un izvairīties no nevēlamām komplikācijām (White, 2009; Quereshy, 2008). KSDT izmeklējumi tiek lietoti arī asaru kanālu stenozes diagnostikā un iekšējās auss patologiju izmeklējumos. 


\subsection{KSDT informativitāte augšžokḷa dobuma izmeklēšanā}

Plānojot augšžokḷa dobuma pamatnes paaugstināšanas operāciju, ir jāizvērtē arī augšžokḷa dobuma stāvoklis. Daudzas radiologiski nosakāmas izmaiņas augšžokḷa dobumā liecina par hroniskām vai akūtām saslimšanām, iedzimtām īpatnībām, veidojumiem, kurus ir būtiski izārstēt vai atpazīt pirms operatīvās iejaukšanās, lai novērstu pēcoperācijas komplikācijas (Hodez, 2011). Ar KSDT var noteikt iekaisuma stāvokḷus, gḷotādas retences cistas, mukocēles, antrolītus un izvērtēt traumatiskus bojājumus apvidū. Var arī izteikt varbūtîbu par aspergilozes infekciju dobumā, jo šis mikroorganisms sabiezētās gḷotādas vidusdaḷā bieži vien veido kalcinātus (Hodez, 2011; Mossa-Basha, 2013; Rege, 2012).

Augšžokḷa dobumos visbiežāk radioloǵiski nosakāmā patologiija ir sabiezēta gḷotāda. Dažādās zinātniskajās publikācijās minēts, ka sabiezēta gḷotāda ir radioloǵiski atrasta pat līdz 66\% asimptomātisku pacientu (4.8. attēls).

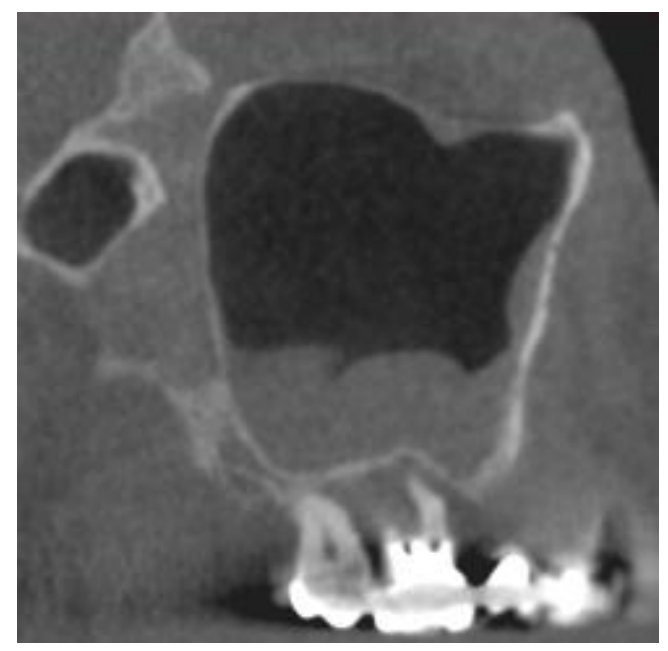

\section{8. att. KSDT izmeklējuma sagitāls griezums. Sabiezēta gḷotāda maksilārā dobuma pamatnē}

Literatūrā pagaidām nav atrodama vienprātîba par to, cik liels gḷotādas sabiezējums ir uzskatāms par patoloǵisku. Visbiežāk minētais gḷotādas biezums, ko varētu uzskatīt par normālu, svārstās no 3 līdz 5 mm (Rege, 2012; Carmeli, 2011; Ashraf, 2001; Lund, 1997; Lund, 1993; Vallo, 2010). Gḷotāda augšžokḷa dobumā parasti sabiezē kāda konkrēta kairinātāja ietekmē. Visbiežāk tas ir odontogēna rakstura kairinātājs, alergēns, bakteriāls, virāls vai sēn̄̄šu izraisīts kairinājums (Brooks, 2006 (1); Brooks, 2006 (2); Nishimura, 2002; Hauman, 2002; Yoshiura, 1993; Mehra, 2004). 
Gḷotādas sabiezējums var būt lokāls vai arī lokalizēties visa dobuma bazālajā dạ̦ā. Bieža radiologiiska atrade maksilārajos dobumos ir lokāli, cistiski sabiezēta glotāda, saukta arī par gḷotādas retences cistu (Donizeth - Rodrigues, 2013) (4.9. attēls).

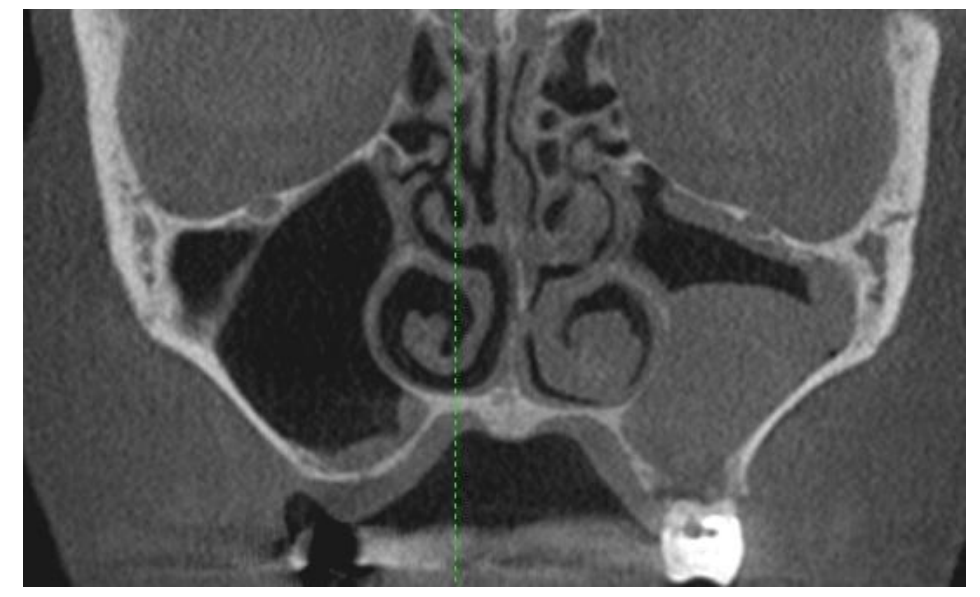

4.9. att. KSDT izmeklējums, koronāls griezums.

Gḷotādas retences cista kreisā maksilārā dobumā

Dobumā gḷotāda var būt sabiezēta gar visām sienām - cirkulāri; tā var būt sabiezēta neregulāri (4.10. attēls),

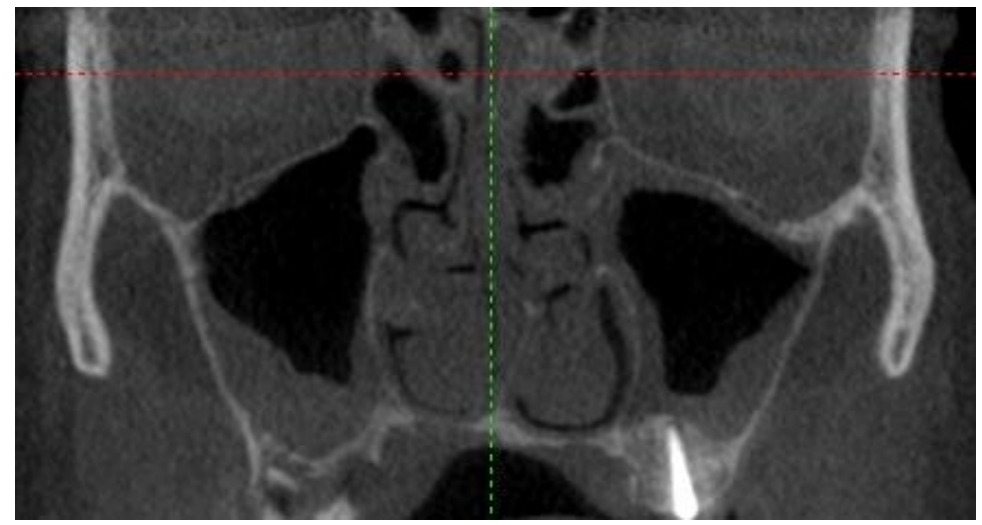

4.10. att. KSDT izmeklējums, koronārs griezums. Labās puses dobumā gḷotāda sabiezēta neregulāri, kreisās puses dobumā - cirkulāri gar visām sienām

vai aizēnot deguna dobumu pilnībā (Carmeli, 2011; Yoshiura, 1993) (4.11. attēls). 


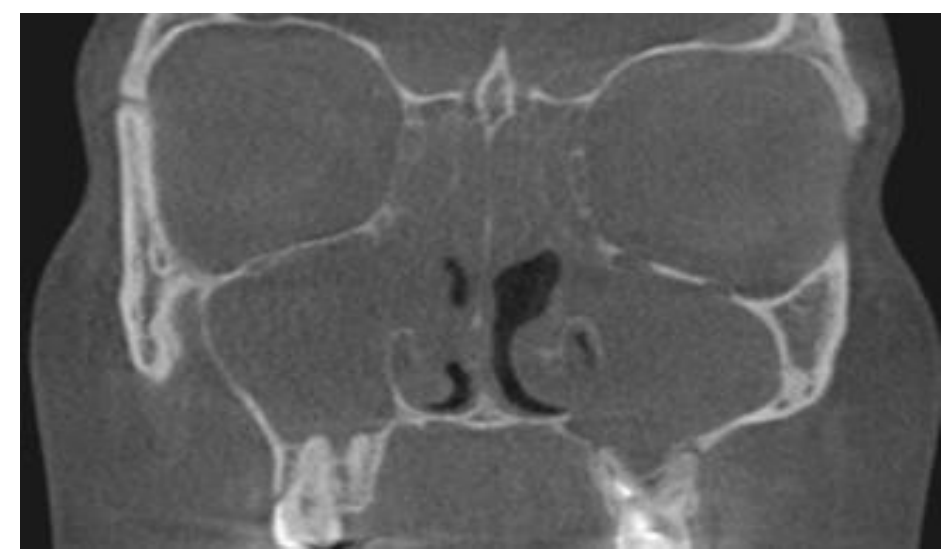

4.11. att. KSDT izmeklējums, koronāls griezums.

Totāli aizēnoti augšžokḷa dobumi un etmoidālās šūnas

Totāli aizēnots dobums un cirkulāri sabiezēta gḷotāda tiek uzskatīta par nelabvēlīgu faktoru veiksmīgai augšžokḷa dobuma pamatnes paaugstināšanas operācijai. Preoperatīvi radioloǵiski atklājot šādas izmaiņas deguna maksilārajā blakus dobumā ir biežāk sagaidāmas postoperatīvas komplikācijas, kas saistītas ar dobuma drenāžas traucējumiem (Carmeli, 2011).

Augšžokḷa blakusdobumi savienojas ar deguna dobumu caur fiziologisko atveri (4.12. attēls), kas atrodas dobuma mediālās sienas augšējā daḷā. Tā atveras uz deguna dobuma

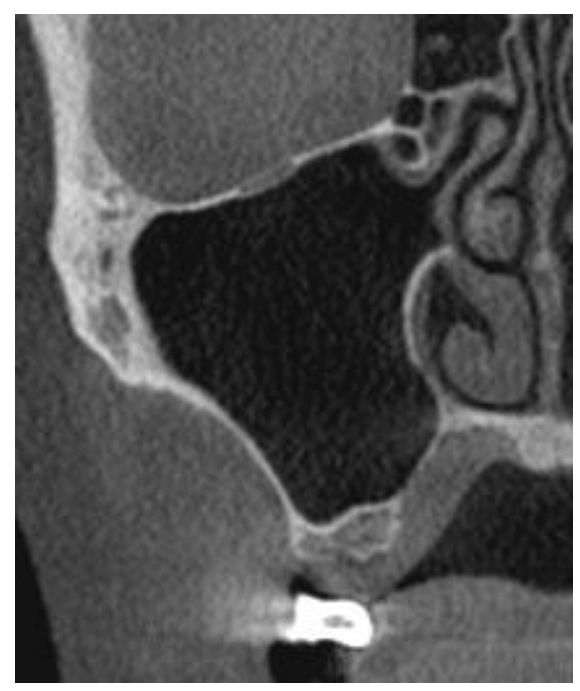

4.12. att. KSDT izmeklējums, koronāls griezums.

Labās puses maksilārā dobuma fizioloğiskā atvere 
vidējo eju. Atvere atrodas vidēji 25,6 mm uz augšu no deguna pamatnes (Gosau, 2009). Skropstiṇu epitēlija, kas izklāj augšžokḷa dobumu, skropstiṇu kustības virziens ir tāds, ka tās virza dobuma saturu fiziologíiskās atveres virzienā. Saturs nonāk deguna dobumā, tad nazofaringeālā telpā, pēc tam tiek norīts. Fizioloğiskās atveres obstrukcijas gadījumā saturs no augšžokḷa dobuma netiek izvadīts. Fiziologiskās atveres obstrukcija ir labi vizualizējama KSDT izmeklējumos. Atveres obstrukcija preoperatīvos trīs dimensiju izmeklējumos tiek uzskatīta par kontrindikāciju augšžokḷa dobuma pamatnes paaugstināšanas operācijas veikšanai (Ozyuvaci, 2005). Fizioloǵiskās atveres obstrukcija bieži kombinējas ar sabiezētas glotādas atradni radiologiskos izmeklējumos. Tas liecina par hronisku rinosinusītu (Hodez, 2011; Carmeli, 2011; Lund, 1997).

Maksilārajos dobumos dažreiz var redzēt papildus atveri uz deguna dobuma vidējo eju (4.13. attēls).

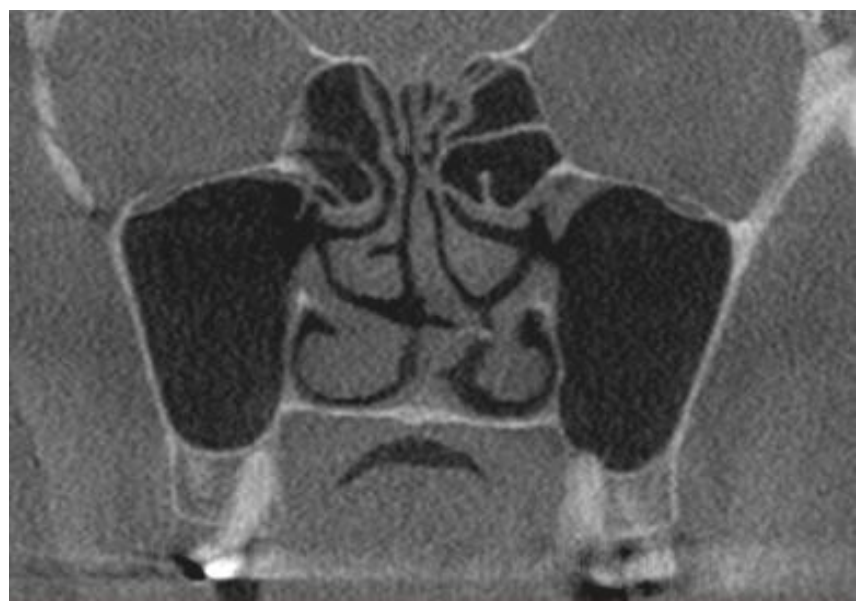

\subsection{3. att. KSDT izmeklējums, koronāls griezums. Abpusējas papildu atveres}

Tā ir izveidojusies pēc viena vai vairākiem iekaisumiem un arī tiek uzskatīta par hroniska rinosinusīta radiologisko pazīmi. Parasti šī papildu atvere lokalizējas dorsāli no fiziologiskās atveres un šādu atradni sauc par „divu atveru sindromu”. Nepareizi tiek uzskatîts, ka papildu atvere darbojas kā fiziologiiskās atverees palīgatvere. Tā kā skropstinuu epitēlijs virza gḷotas fiziologiskās atveres virzienā, tad papildu atvere tiek apieta. Savukārt, kad gḷotas nokḷūst deguna dobumā un tiek virzītas dorsāli uz rīkles pusi, tad tās caur papildu atveri atkal nokḷūst augšžokḷa dobumā. Veidojas gļotu gredzens, kas caur fiziologisko atveri tiek vadīts ārā no augšžokḷa dobuma, bet caur papildu atveri nokḷūst atpakaļ dobumā. Šāda situācija rada kairinājumu un papildus iekaisuma risku (Mladina, 
2009; Mladina, 2010; Kumar, 2001). Vairāk nekā pusei (55\%) rinosinusīta pacientu ir radiologiski redzama papildu atvere. Veseliem cilvēkiem papildus atveres ir redzamas tikai 7 \% gadījumu (Mladina, 2009; Mladina, 2010).

Anatomisko struktūru variācijas, kas var sašaurināt vidējo deguna eju augšžokḷa dobuma fiziologiskāas atveres līmenī, tiek uzskatīta par dobuma obstrukcijas un saslimšanu riska faktoru. Pie šādām anatomiskām pārmaiṇām pieder deguna starpsienas deviācija, pneimatizêta vidējā deguna gliemežnīca - concha bullosa (4.14. attēls) un etmoidālās šūnas, kas lokalizējas zem orbītu līmeņa (Caughey, 2005). Visas šīs anatomiskās struktūras

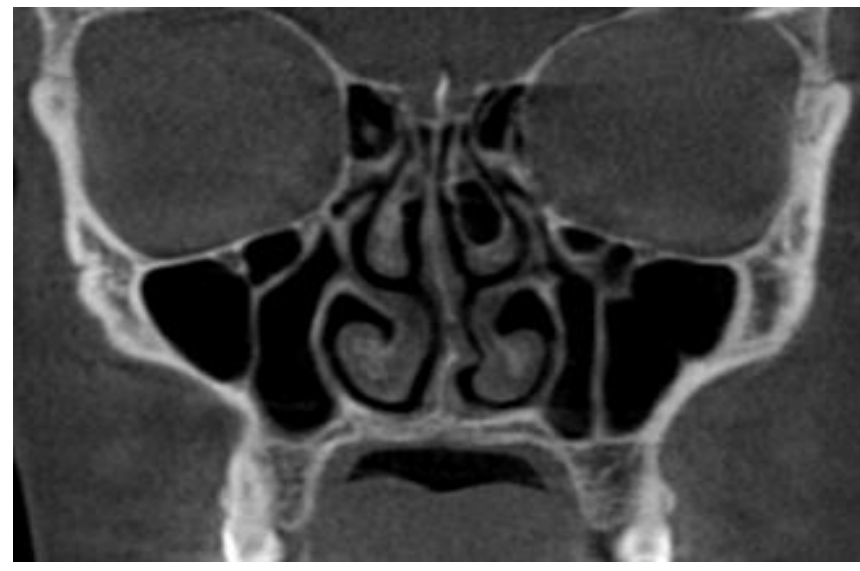

\subsection{4. att. KSDT izmeklējums, koronāls griezums. Pneimatizēta kreisās puses vidējā gliemežnīca - concha bullosa}

ir labi vizualizējamas KSDT izmeklējumos. Literatūrā ir atrodami dati, kas apstiprina šo anatomisko izmaiṇu nelabvēlīgu ietekmi uz dobuma funkciju (Caughey, 2005), kā arī dati, kas šādu saistību neatrod (Smith, 2010; Nouraei, 2009).

Radiologiski maksilārajos dobumos ir redzamas nepilnīgas starpsienas, sauktas par septām (4.15. attēls). 


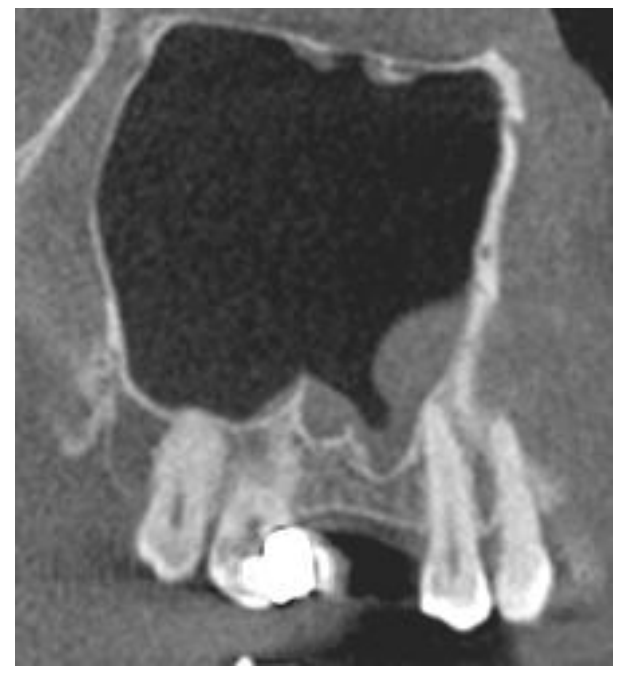

\subsection{5. att. KSDT izmeklējums, sagitāls griezums.}

Septa augšžokḷa dobuma pamatnē

To daudzums, lokalizācija un lielums katram indivīdam ir atšķirīgs (Neugebauer, 2010; Gosau, 2009; Kim, 2006). Uzskata, ka to funkcija ir mastikatorās slodzes izlīdzināšana (Van den Bergh, 2000). Septu esamības un lokalizācijas noteikšanai ir svarīga nozīme implantācijas un augšžokḷa dobuma pamatnes paaugstināšanas gadījumos. Situācijās, kad alveolārā kaula atrofija nav izteikta un implantātu ievietošanai nepieciešams tikai nedaudz vairāk balsta audu, septu var izmantot kā papildus balsta audus implantātu apikālajā daļā (Pal, 2012). Situācijās, kad nepieciešams veikt augšžokḷa dobuma pamatnes paaugstināšanas operāciju, septu lokalizācija jānosaka, lai samazinātu Šneidera membrānas perforācijas risku. Membrānu ir grūtāk atdalīt no nelīdzenas virsmas, no septas, nekā no gludas kaula virsmas. Septu esamība palielina Šneidera membrānas perforācijas risku. Populācijā dobuma septas ir atrodamas 16-70\% indivīdu (Van den Bergh, 2000; Van Zyl, 2009; Koymen, 2009; Maestre - Ferrin, 2010; Maestre - Ferrin, 2011). Precīza to lokalizāciju noteikšana samazina komplikāciju risku. Salīdzinājumā ar konvencionālo divdimensiju attēlu diagnostiku KSDT uzrāda precīzu septu lokalizāciju, skaitu un izmērus (Maestre-Ferrin, 2011). 


\subsection{Augšžokḷa dobuma pamatnes paaugstināšanas operācija un KSDT nozīme tās plānošanā}

Augšžokḷa alveolārā kaula atrofijas rezultātā tā dimensijas izmainās. Alveolārais izaugums var saglabāties augsts, bet šaurs - kā naža asmens. Divdimensiju attēlā šāds alveolārais izaugums var maldināt ārstu par implantācijas iespēju. Biežāk gan alveolārais kauls atrofējas kā augstumā, tā platumā, zaudējot iespēju veikt implantāciju bez papildus maksilārā dobuma pamatnes paaugstināšanas operācijas, ko parasti veic aizpildot vietu zem Šneidera membrānas ar biomateriāliem. Augšžokḷa alveolārā kaula atrofija klīniski var būt minimāla, tomēr augšžokḷa dobuma pneimatizācija - tik izteikta, ka tas aizņem lielāko daļu no alveolārā izauguma. Arī šādā gadījumā veiksmīga implantācija bez papildu augstuma iegūšanas ir neiespējama. Komplikāciju novēršanas nolūkš ir nepieciešama precīza preoperatīva plānošana, kuras pamatā ir operācijas lauka vizualizācija. KSDT ir izvēles metode šādu sarežǵìtu operatīvu darbību plānošanā, jo tā sniedz iespēju paredzēt operācijas lauku trīs dimensijās. Salīdzinājumā ar citām trīs dimensiju metodēm KSDT ir mazākā starojuma deva pacientam (European Commission, 2012; White, 2009).

Augšžokḷa dobuma pamatnes paaugstināšanas operāciju (ADPP), sauktu arī par sinusa liftu vai sinusa pamatnes augmentāciju, parasti lieto gadījumos, kad ir nepieciešams lielāks augšžokḷa mugurējās daḷas alveolārā izauguma augstums. Iemesli tam var būt dažādi, bet visbiežāk šo operāciju veic, lai nodrošinātu veiksmīgu zobu implantāciju. Zobu implantācijas gadījumos, kad ar atrofiskā reziduālā alveolārā kaula augstumu vien nepietiek, lai nodrošinātu implantāta stabilitāti, to papildus nodrošina augmentētā zona. Šāda operācija pirmo reizi tika veikta 1974. gadā. To veica zobārsts Oskars Hilts Tatums juniors (Summers, 1998), dzimis 1934. gada 22. aprīlī Opelikā, Alabamas štatā, Amerikas Savienotajās Valstīs (ASV). Laterālās pieejas sinusa pamatnes augmentācijas operācija kā metode ASV tika patentēta 1998. gadā. Patenta numurs US005711315A (US Patent and Trademark Office, 1998).

Augšžokl̦a dobuma pamatnes paaugstināšanu var veikt divējādi atkarībā no reziduālā alveolārā kaula augstuma. Ja alveolārā kaula augstums ir mazāks par 5-6 mm, tad veic laterālā loga pieeju pamatnes paaugstināšanai. Literatūrā laterālā loga antrotomijas metodi sauc arī par tiešo metodi. Ja reziduālā kaula augstums ir vairāk nekā $6 \mathrm{~mm}$, tad var tikt veikta slēgtā jeb osteotoma dobuma pamatnes augmentāciju. Šo tehniku sauc arī par netiešo metodi $(\mathrm{Pal}, 2012)$ 
Laterālās pieejas augšžokḷa augmentācijai paredzētajā zonā tiek veikta infiltrācijas anestēzija, pēc tam veikts grieziens un pacelts mukoperiostālais lēveris. Kauls ir atsegts. Ar mikromotora urbi tiek veikta osteotomija, izveidots logs kaulā, kurš uzmanīgi, lai neperforētu Šneidera membrānu, tiek iebīdīts augšžokḷa dobumā. Izveidotā telpa tiek piepildīta ar biomateriāliem (4.16. attēls).

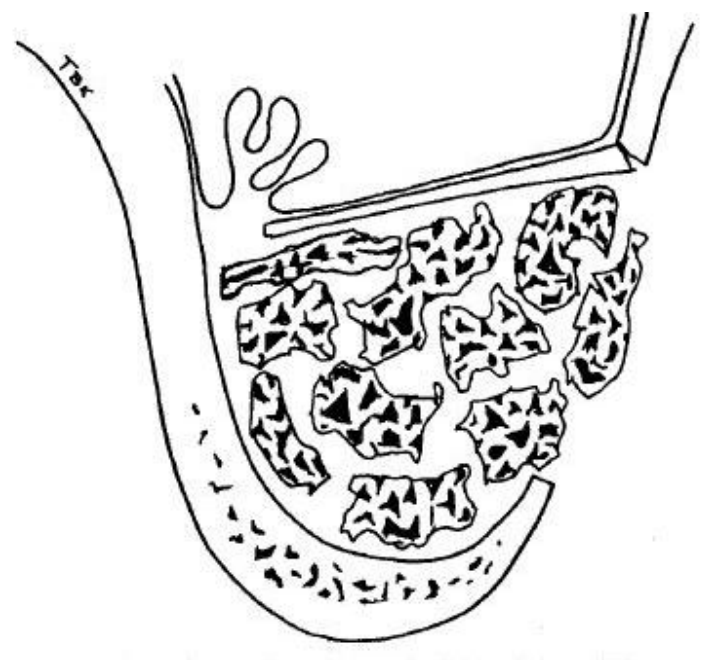

\subsection{6. att. Augšžokḷa dobuma pamatnes paaugstināšanas}

metode ar laterālo pieeju (Van den Bergh, 2000)

Veicot viena etapa augšžokḷa dobuma pamatnes paaugstināšanas operāciju vienlaicīgi tiek ievietots arī viens vai vairāki implantāti. Osteotomijas logs dažreiz tiek slēgts ar titāna membrānu vai citreiz tikai nosegts ar mukoperiostālo lēveri. Abos gadījumos mukoperiostālais lēveris tiek sašūts un brūce slēgta (Van den Bergh, 2000; US Patent and Trademark Office, 1998; Abrahams, 1998).

Netiešā augšžokḷa dobuma pamatnes paaugstināšanas operācija jeb osteotoma metode tiek pielietota, kad ir plānots paaugstināt vertikālo dimensiju vēl par 3-4 mm (Pal, 2012). Netiešās metodes gadījumā griezums tiek veikts tā, lai atsegtu alveolārā kaula malu. Tad tiek veikts urbums kaulā, un augšžokḷa dobuma grīda tiek ielauzta un pacelta kopā ar Šneidera membrānu. Zem tās tiek ievietoti biomateriāli un ieskrūvēts implantāts (4.17. attēls) (Summers, 1998). 


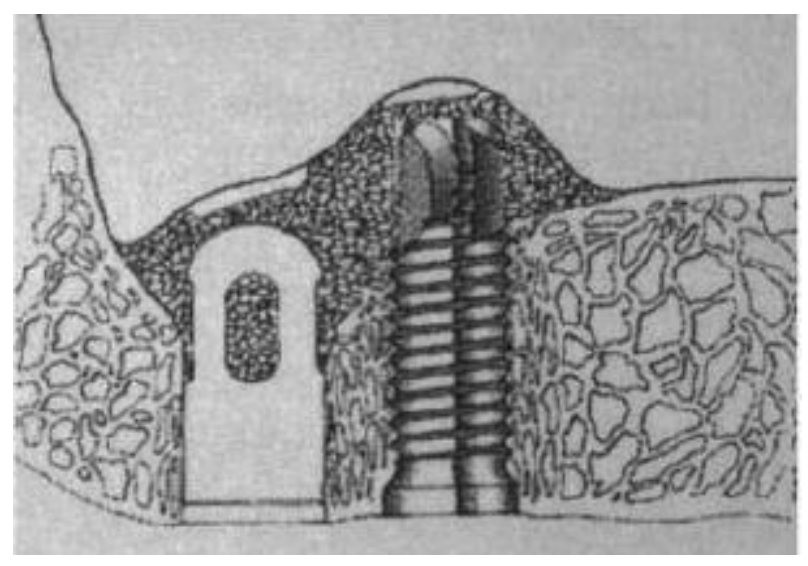

4.17. att. Augšžokḷa dobuma pamatnes paaugstināšana netiešā metode (Summers, 1998)

Augšžokḷa dobuma paaugstināšanas operāciju var veikt vienā etapā ar implantātu ievietošanu. Tas nozīmē, ka augmentācijas veikšanas laikā tiek ievietoti arī viens vai vairāki implantāti. Ja tiek veikta divu etapu augšžokḷa dobuma pamatnes paaugstināšanas operācija, tad pirmajā etapā tiek veikta augmentācija, bet otrajā, pēc apmēram 5-6 mēnešiem, augmentētajā zonā tiek ievietoti implantāti. Divu etapu augmentācijas operāciju parasti izvēlas, ja kaula augstums ir ļoti mazs un tas nevar nodrošināt implantātu primāro stabilitāti.

\subsection{KSDT informativitāte augšžokḷa dobuma pamatnes paaugstināšanas pēcoperācijas izmeklēšanā}

Izvērtējot augšžokḷa dobuma operācijas rezultātus radiologiski, līdzīgi kā pirms operācijas jāizvērtē augšžokḷa dobuma stāvoklis. Sabiezēta gḷotāda un fizioloğiskās atveres obstrukcija liecina par iekaisuma esamību dobumā, kas var būt radies operatīvas iejaukšanās rezultātā. Izvērtējot augšžokḷa dobumu uzreiz pēc operācijas, var būt redzams šķidruma līmenis, kas varētu būt operācijas rezultātā radies saasiņojums. Ja kontrole tiek veikta pēc ilgāka laika, tad saasiṇojums jau ir uzsūcies un radiologiski nav nosakāms. Radiologiski redzamais šķidruma līmenis visbiežāk ir gḷotas, strutas, kas liecina par akūtu iekaisuma procesu, un var būt redzams uzreiz pēc operatīvās iejaukšanās, vai asinis, kas var krāties dobumā uzreiz pēc traumatiska bojājuma vai Šneidera membrānas perforācijas. Akūts sinusīts pēc augšžokḷa dobuma paaugstināšanas operācijas ir sastopams tikai $1 \%$ 
gadījumu. Tas skaidrojams ar dobuma gḷotādas spēju pielāgoties izmaiņām (Zijverveld, 2008). Ilgstošākā laika periodā notiek gḷotādas sabiezēšanās, kas var kombinēties ar gḷotu klātbūtni, bet šķidruma līmeņus radioloǵiski šādos gadījumos parasti nevēro. Var būt situācijas, kad augmentācija radioloǵiski ir sekmīga, bet virs tās vērojama sabiezēta gḷotāda (Abrahams, 2000). Izteikta iekaisuma gadījumā augšžokl̦a dobums var būt totāli aizēnots un var sabiezēt kaula sienas - osteīts (Harnsberger, 2011).

Gadījumos, kad ilgtermiṇā radiologiiskā kontrolē redz sabiezētu gḷotādu vai totāli aizēnotu dobumu, ir jāizvērtē šīs atrades iemesls. Biežākā radiologiski nosakāmā komplikācija, kas var rasties augšžokḷa dobuma pamatnes paaugstināšanas operācijas laikā, ir Šneidera membrānas perforācija, kas bieži kombinējas ar biomateriālu nokḷ̂̄šanu dobumā. Tad radiologiiski redz biomateriālu granulas kā sīkus, blīvus graudinus, ieskautus sabiezētā glotōāā. Gḷotāda var būt tik sabiezēta, ka dobums ir pilnībā ar to aizpildīts. Dažreiz drīz pēc augšžokḷa pamatnes paaugstināšanas operācijas var redzēt dobuma veidošanos operācijas vietā - augmentētās zonas abscedēšanās. Visbiežāk tās cēlonis ir infekcijas aǵents operācijas zonā (Abrahams, 2000). Tomēr tā ir akūta reakcija, ko, ilgtermiṇā izvērtējot augšžokḷa dobuma stāvokli pēc pamatnes paaugstināšanas, nevēro.

Pēc veiksmīgas augšžokḷa dobuma pamatnes paaugstināšanas operācijas, izmantojot kaulu aizstājošos biomateriālus, radiolog̣iski redz ieapaļas formas, kupolveidīgu paaugstinājumu augšžokḷa dobuma pamatnē, kas piegulst augšžokḷa reziduālajam alveolāram kaulam. No augšpuses to apņem Šneidera membrāna, kas nav sabiezēta. Augšžokḷa dobums un tā fiziologiskā atvere ir pneimatizēti.

Lai izvērtētu augmentētās zonas dimensijas, var lietot dažādas radiologiskās metodes. Veicot intra vai ekstraorālos radioloǵiskos izmeklējumus, tiek iegūts augmentētās zonas attēls plaknē. Tā var izvērtēt transplantāta vertikālās dimensijas, bet horizontālās dimensijas izvērtēt nav iespējams. Visbiežāk lietotās divdimensiju attēla diagnostikas metodes augšžokḷa dobuma pamatnes augmentācijas gadījumos ir dentālās panorāmas tomogrāfija vai intraorālie izmeklējumi. Abas metodes ir atkārtojamas un laika gaitā salīdzināmas, kā arī tām ir mazāka pacienta starojuma deva. Dentālās panorāmas tomogrāfija joprojām tiek plaši lietota augšžokļa dobuma augmentācijas plānošanā un pēcoperatīvo rezultātu izvērtēšanā (Heinemann, 2009; Chipasco, 2008; Lindgren, 2012; Hallman, 2005; Schmitt, 2012; Riachi, 2012), tomēe trīsdimensiju attēla diagnostika rada iespēju izvērtēt augmentēto zonu arī horizontālā plaknē. Šī priekšrocība, kā arī precīzākas anatomisko struktūru un mīksto audu izvērtēšanas iespējas nodrošina, ka trīs dimensiju attēla diagnostika - daudzslāṇu datora tomogrāfija 
un konusa stara datora tomogrāfija - bieži vien ir izvēles metode pēcoperatīvā stāvokḷa izvērtēšanai. Pirms KSDT plašās pieejamības daudz tika lietoti DSDT izmeklējumi (Johansson, 2001; Peleg, 1999; Kirmeier, 2008; Sbordone, 2012; Sbordone, 2009), tomēr to starojuma deva ir ievērojami lielāka. Literatūrā ir pieejami pētījumi, kur pēc operācijas izvērtējumu augšžokḷa dobuma paaugstināšanas gadījumos veic ar KSDT izmeklējumu (Shanbhag, 2013; Pramstraller, 2011; Klijn, 2012; Umanjec - Korac, 2013). Tomēr šāda veida literatūras dati pagaidām ir ierobežotā daudzumā, kas skaidrojams ar to, ka KSDT metode ir salīdzinoši jauna. Izmeklējot pacientu ar KSDT, tāpat kā ar DSDT, var izvērtēt augmentētās zonas dimensijas un to izmaiṇas laikā (Kau, 2009).

\subsection{Augšžokḷa dobuma pamatnes paaugstināšanas operācijas komplikācijas}

Pēc augšžokḷa dobuma paaugstināšanas operācijas ir iespējamas dažādas komplikācijas. Pēc operācijas komplikācijas ir sastopamas pat līdz $30 \%$ pacientu (Herzberg, 2006).

\subsection{1. Šneidera membrānas perforācija}

Visbiežāk sastopamā komplikācija augšžokḷa dobuma pamatnes paaugstināšanas operāciju gadījumā ir Šneidera membrānas perforācija. Tā ir sastopama no 10 līdz 60 \% gadījumu (Zijderveld, 2008; Anavi, 2008; Barone, 2006). Šneidera membrānas perforācijas gadījumos iemesls var būt gan anatomiskās variācijas, gan tehniskais izpildījums. Anatomiskās variācijas, kas palielina membrānas perforēšanas risku, ir nelīdzena dobuma pamatne, iepriekšējas operācijas dobumā (sarētojumi), septas, mutes gḷotāda un Šneidera membrānas saaugums, kā arī mazs alveolārā izauguma augstums. Tas ir skaidrojams ar to, ka šādos gadījumos atdalīt Šneidera membrānu no kaula ir grūtāk un ir nepieciešams atbrīvot lielāku kaula lauku (Ardekian, 2006; Malkinson, 2009). Šīs anatomiskās variācijas ir viegli nosakāmas radiologiski, izmeklējot ar trīs dimensiju attēla diagnostikas metodēm. Literatūrā atrodami ar̄̄ dati, kas rekomendē pamatnes paaugstināšanas operāciju veikt endoskopijas kontrolē, jo šī metode labāk demonstrē, vai ir notikusi perforācija (Garbacea, 2012). 
Parasti Šneidera membrānas perforācijas piesedz ar rezorbējošu kolagēna membrānu (Fugazzoto, 2003; Clementini, 2013). Lielu perforāciju gadījumos, kad tiek lietots biomateriāls granulās, kas viegli var nokļūt augšžokḷa dobumā, operācija ir jāpārtrauc un jāturpina pēc tam, kad Šneidera membrāna ir sadzijusi. Pretējā gadījumā biomateriālu diseminācija augšžokḷa dobumā var provocēt dažādu gḷotādu patolog̣iju veidošanos (Ardekian, 2006).

\subsubsection{Asiṇošana}

Augšžokḷa artērija (a. maxillaris) dod trīs zarus, kas apasiņo augšžokḷa dobumu: mugurējā augšējā alveolārā artērija (a. alveolaris posterior superior), infraorbitālā artērija (a. infraorbitalis) un mugurējā augšējā deguna artērija (a. nasale posterior superior) (Dauber, 2007; Ella, 2008). Tās savā starpā veido anastomozes dobuma kaula sienā. Ir konstatēts, ka dobuma laterālajā sienā asinsvadi un anastomozes atrodas apmēram 16-19 mm no alveolārā izauguma malas (Elian, 2005; Solar, 1999). Šis attālums būtu pietiekams, lai varētu veikt pamatnes paaugstināšanas operāciju, netraumējot asisnsvadus. Tomēr jāatceras, ka izteiktas alveolārā izauguma atrofijas gadījumā šī distance samazinās un asiņošana operācijas laikā ir biežāka komplikācija (Zijderveld, 2008; Van Den Bergh, 2000; Apostolakis, 2013). Arī plašu kaula logu veidošana operācijas pieejas vietā palielina asinsvadu traumatizācijas risku. Asinsvadu gultnes labi vizualizējas datora tomogrāfijas izmeklējumu attēlos (Solar, 1999; Ella, 2008).

Gadījumos, kad pacients pēc operācijas sūdzas par asiņošanu no deguna - epistaksi, ar lielāko varbūtību jādomā par operācijas laikā nepamanītu Šneidera membrānas perforāciju (Zijderveld, 2008). Pēc operācijas asiṇošanas biežums ir neliels, līdz 12,5\% pēc operācijas gadījumos (Nooh, 2013).

\subsubsection{Pēcoperācijas augšžokḷa dobuma iekaisums}

Augšžokḷa dobuma iekaisums pēc dobuma pamatnes paaugstināšanas operācijas ir reti sastopams stāvoklis. To novēro tikai 1\% pacientu, ja preoperatīvi pacientam nav bijušas hroniskas vai akūtas deguna blakusdobumu saslimšanas (Zijderveld, 2008; Ardekian, 2006; Alkan, 2008). Veicot pacientu pētījumus pēc augšžokḷa dobuma 
pamatnes paaugstināšanas operācijas, ir konstatēts, ka dobumu klājošās gḷotādas šūnas pēc operācijas pielāgojas jaunajam stāvoklim. Operatîvā iejaukšanās neizmaina gḷotādas normālo fiziologiisko funkciju (Timmenga, 2003). Desmit procentu gadījumu var novērot pēc operācijas, dobuma inficēšanos vai cistiski sabiezētu gḷotādu ap augmentācijas apvidu (Schwartz - Arad, 2004). Plānojot augšžokḷa dobuma paaugstināšanas operāciju jāizvērtē dobuma stāvoklis. Iekaisuma vai citu saslimšanu gadījumos tie ir jānovērš. Operācija veicama tikai pēc tam, kad radiologiski apstiprinās, ka augšžokḷa dobuma stāvoklis ir uzlabojies un nav patologisiskas atrades (Anavi, 2008).

\subsubsection{Augmentētās zonas infekcija}

Augmentētās zonas sadzī̌sana un remodelācija ir atkarīga no Šneidera membrānas, bukālā mukoperiostālā lēvera un kaula vaskularizācijas (Van Den Bergh, 2000). Infekcija augmentētajā zonā ir reti sastopama, un mutes dobuma, kā arī augšžokḷa dobuma normālās mikrofloras parasti nerada augmentētās zonas infekcijas draudus. Infekciju šajā zonā visbiežāk var ienest ar augmentēšanas materiālu, kas var izraisīt abscedēšanos un arī sinusītu (Ardekian, 2006). Pēc operācijas infekcijas risks augmentācijas zonā ir sastopama līdz 2\% gadījumu (Caudry, 2013). Šādu komplikāciju novēršanas nolūkā profilaktiski lieto antibakteriālos un pretiekaisuma līdzekḷus (Misch, 1992).

\subsubsection{Oroantrāla fistula}

Oroantrāla fistula var veidoties augmentētās zonas abscedēšanās gadījumā, Šneidera membrānas perforācijas gadījumā, kā arī revīzijas veikšanas gadījumos, lai novērstu komplikācijas pēc augšžokḷa dobuma paaugstināšanas operācijas (Anavi, 2008).

\subsubsection{Augmentētās zonas un zobu implantātu zaudējums}

Augšžokḷa dobuma pamatnes paaugstināšanas operāciju komplikācijas, kuru rezultātā var tikt zaudēta augmentētā zona un implantāti, ir retas. Literatūras dati norāda, ka augšžokḷa dobuma pamatnes paaugstināšanas operācijas ir veiksmīgas 88,6\% līdz 100\% 
gadījumu (Caudry, 2013). Šneidera membrānas perforācija augmentācijas laikā nav saistîta ar zobu implantātu vai augmentētās zonas zaudēšanu (Ardekin, 2006; Barone, 2006), tomēr ir atrasta negatīva korelācija starp membrānas perforācijas lielumu un zaudētiem implantātiem (Hernandez - Alfaro, 2008). Pie zobu implantātu un augmentētās zonas zaudējuma var novest ķirurga neprasme vai savu spēju pārvērtēšana (4.18. attēls). Ķirurga kompetence un pieredze, kā arī uzmanīga attieksme operācijas laikā samazina iespējamo komplikāciju skaitu (Zijderveld, 2008; Van Den Bergh, 2000; Anavi, 2008; Malkinson, 2009).

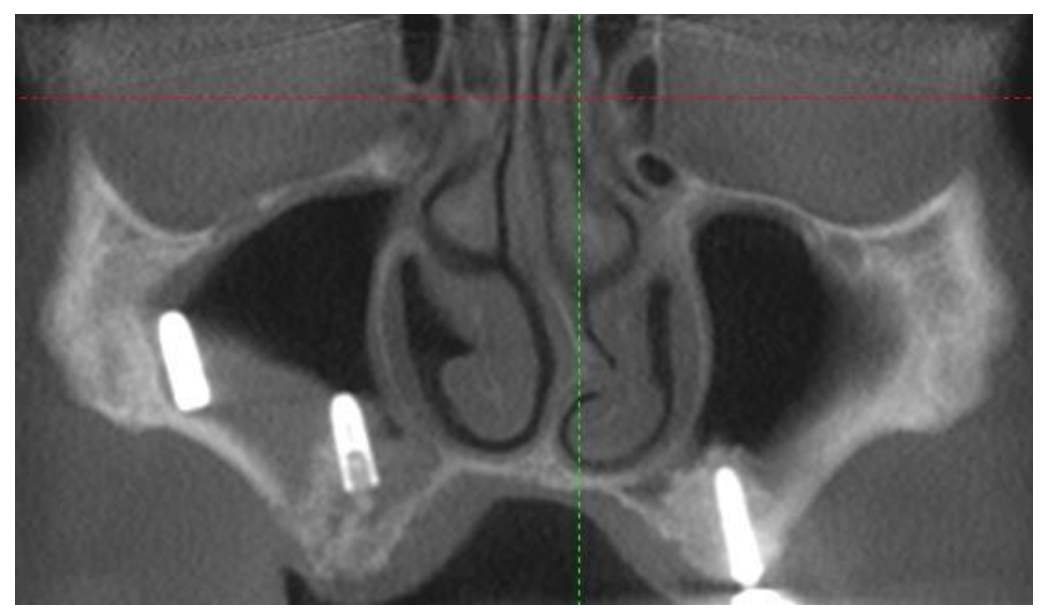

4.18. att. Implantātu un augmentētās zonas zaudējums labajā pusē.

KSDT izmeklējums

\subsection{Augšžokḷa dobuma paaugstināšanas operācijas kontrindikācijas}

Augšžokḷa dobuma paaugstināšanas operācijai nav absolūtu kontrindikāciju. Katrs gadījums ir jāvērtē atsevišķi. Tomēr ir vairāki stāvokḷi, kas jāņem vērā izvērtējot iespēju veikt dobuma pamatnes paaugstināšanu. Šneidera membrānas saaugums ar mutes dobuma gḷotādu, kas ir bieži vērojams stāvoklis, kāds veidojas pēc traumatiskas zoba ekstrakcijas, dobuma pamatnes perforācijas, apgrūtina augšžokḷa dobuma paaugstināšanas operāciju. Operācijas plānošana šādos gadījumos ir jāveic ar īpašu piesardzību (Van den Bergh, 2000).

Iepriekšējas operācijas augšžokḷa dobumos, īpaši operācijas, kas veiktas pēc Kaldvela - Luka metodikas, var radīt sarežğījumus veicot dobuma paaugstināšanas operāciju. 
Neārstēti, iekaisuma stāvokḷli augšžokḷa dobumos var radīt komplikācijas postoperatīvi. Šì ir pagaidu kontrindikācija, jo operāciju var veikt pēc augšžokḷa dobuma izārstēšanas (Van den Bergh, 2000; Anavi, 2008).

Augšžokḷa dobuma pamatnes paaugstināšanas operācija un implantācija osteoporozes pacientiem nav kontrindicēta. Osteoporoze ir visvairāk pētîtā kaulu saslimšana sejas - žokḷu apvidū. Žokḷu kaula blīvuma salīdzināšana ar vispārpieņemto kaulu minerālu blīvuma analīzi nesniedz viennozīmīgus rezultātus (Diz, 2013; Neimane, 2013). Osteoporozes pacientiem zobu implantācijas gadījumos nav sagaidāmi sliktāki rezultāti kā pacientiem bez osteoporozes (Bornstein, 2009). Augšžokḷa dobuma paaugstināšanas operācija osteoporozes pacientiem ir kontrindicēta gadījumos, ja pacients osteoporozes ārstēšanā lieto bifosfonātus. Bifosfonātu terapija ir saistīta ar iespējamu kaulu nekrozi žokḷlos. Rezultātā var tikt zaudēta gan augmentētā zona, gan implantāti (Diz, 2013).

Pacienta smēķēšana ilgākā laika posmā ir sliktāku rezultātu iemesls. Smēķētājiem novēro augmentētās zonas un implantātu zaudējumu, kā arī kaula balsta augstums zudumu ap implantātiem pat divas reizes biežāk nekā nesmēķētājiem (Herzberg, 2006; Baig, 2007). Smēķētājiem biežāk novēro augmentētās zonas inficēšanos nekā nesmēķējošiem pacientiem (Barone, 2006). Tiek uzskatîts, ka izsmēķējot līdz desmit cigaretēm dienā augmentācijas rezultāts netiek nopietni apdraudēts. Prognoze pasliktinās, pieaugot izsmēķēto cigarešu daudzumam (Kan, 1999).

\subsection{Kaulu aizvietojošo biomateriālu pielietojums augšžokl̦a pamatnes paaugstināšanā}

Materiāliem, kurus izmanto augšžokḷa dobuma pamatnes paaugstināšanas operācijās, ir jāatbilst trīm kritērijiem. Tiem ir jānodrošina osteokonduktīva matrice, kas nodrošina asinsvadu invāziju un šūnu infiltrāciju tajā. Materiāliem ir jābūt osteoinduktīviem, kas iniciē un stimulē mezenhimālo šūnu diferenciāciju par kaulu veidojošām šūnām. Materiālu iekšienē izveidotām osteogēnām šūnām jāspēj veidot jaunu kaula matrici un nodrošināt tilpuma stabilitāti (Miron, 2012; Handschel, 2009). No šiem trim kritērijiem izriet, ka augmentācijas materiālu ,zelta standarts” ir autogēns kauls (Miron, 2012; Zimmermman, 2011). 


\subsubsection{Autogēnie materiāli}

Kaula autotransplantātiem piemīt visas dabiskās kaula morfologiskās un funkcionālās īpašības: biomehāniskās īpašības, biosaderība, osteokonduktivitāte, osteoinduktivitāte (Trisi, 2009). Autogēnie materiāli kaula transplantācijai tiek ņemti no tā paša indivīda skeleta kauliem un pārstādīti augšžokḷa dobuma pamatnē. Autogēno materiālu lietošana tiek uzskatīta par augšžokḷa dobuma pamatnes paaugstināšanas „,zelta standartu” (Schlegel, 2004; Schmitt, 2013). Kaula transplantātu var ņemt no distāliem, ekstraorāliem kauliem, piemēram, tībijas, iegurṇa kaula, galvaskausa velves kauliem. Tiek ņemti arī transplantāti kauli no intraorāliem kauliem, piemēram, no zoda, no apakšžokḷa pamatnes laterāliem segmentiem, no augšžokḷa paugura (Browaeys, 2007). Kaula transplantāta iegūšana no distālām vai proksimālām skeleta daḷām pacientam ir nepatīkamas un rada ilgākas pēcoperācijas sekas. Tādēḷ tiek meklēti alternatīvi materiāli (Miron, 2012; Zimmermman, 2011; Handschek, 2009).

Pētījumos ir konstatēts, ka 6-12 mēnešu laikā pēc kaula transplantācijas vērojama autotransplantāta rezorbcija līdz pat $60 \%$ no tā daudzuma un, lietojot autotransplantātus, rezorbcija ir neizbēgama (Jensen, 1998; Raghoebar, 1999; Lambert, 2011). Veicot pētījumu ar iegurņa kaula transplantātiem, tika konstatēts, ka gada laikā tiek zaudēts līdz pat 50\% no transplantāta tilpuma (Sbordone, 2009). Radioloǵiskajā pētījumā, kur tika reǵistrēts iegurṇa kaula autotransplantāta tilpuma zudums ar datora tomogrāfijas metodi 6 gadus pēc transplantācijas operācijas, tika atklāts, ka tā rezorbcija ir pat $105 \%$. Tātad aktīvas rezorbcijas rezultātā ir rezorbējies ne tikai transplantāts, bet turpinājusies arī atlikušā alveolārā izauguma rezorbcija (Sbordone, 2012). Citā radiologiiskajā pētījumā, kurā tika izvērtētas iegurņa kaula transplantāta dimensijas desmit gadu laikā pēc operācijas, tika konstatēts, ka lielākais transplantāta vertikālais zudums ir vērojams pirmā gada laikā pēc operācijas. Pēc pirmā postoperatīiā gada tas vidēji bija līdz 20\%. Turpmākajos gados rezorbcija izlīdzinās un norit vienmērīgi nelielos apjomos un sasniedz vēl 10\% no sākotnējā transplantāta augstuma (Schmitt, 2012). Interesanti, ka lielāka rezorbcija ir vērojama, ja reziduālā kaula augstums ir lielāks. Savukārt mazāku rezorbciju novēro vecākiem pacientiem (Klijn, 2012), kas skaidrojams ar lēnāk noritošiem metaboliem un remodelācijas procesiem organismā.

Histoloǵiskajos pētījumos ir konstatēts, ka pirmajos 9 pēc operācijas mēnešos autogēnā kaula transplantātos ir visaugstākais mineralizēta kaula daudzums, kas ir tikai loǵiski (Handschek, 2009). Tomēr, lielākā laika posmā salīdzinot mineralizētā kaula 
daudzumu autotransplantāta gadījumā un ksenogēno materiālu gadījumā, kas satur deproteinizētu kaulu vai $\beta$ - trikalcija fosfâts, un to kombinācijās ar autogēno kaulu netika atrasta statistiski ticama mineralizētā kaula daudzuma atšķirība (Handschek, 2009).

\subsubsection{Allogēnie materiāli}

Allogēnie kaulu transplantātu materiāli tiek ņemti no citiem indivīdiem vienas sugas ietvaros, tātad no citiem cilvēkiem. Šie kaula transplantāti tiek iegūti no cilvēku lịķiem. Kauls tiek speciāli apstrādāts, lai tas pēc iespējas zaudētu antigēnās īpašības. Mineralizēti cilvēka kaula allogēnie transplantāti, kuru sastāvā ir 80\% kortikālā un 20\% porainā allogēnā kaula, ir biosaderīgs un derīgs augšžokḷa dobuma pamatnes paaugstināšanai. Ja ir izteikta maksilārā dobuma pneimatizācija un alveolārā izauguma atrofija, kā rezultātā nepieciešama lielāka augmentētā zona, tad ir nepieciešams ilgāks laiks, līdz izveidojas un nobriest jauns kauls (Soardi, 2011). Tomēr šos transplantātus lieto ierobežoti, jo tiem novērota ievērojamu rezorbciju un pastāv infekcijas pārnešanas risks, piemēram, cilvēka imūndeficīta vīrusa, vīrusa hepatīta infekcijas risks (Browaeys, 2007; Kolerman, 2012).

\subsubsection{Ksenogēnie materiāli}

Ksenogēnie materiāli vai ksenogēnie transplantāti ir materiāli, kas iegūti no citas sugas pārstāvjiem. Biežāk lietotie ksenogēnie materiāli augšžokḷa dobuma pamatnes paaugstināšanas operācijās ir vērša vai cūkas kaula deproteinizēti minerāli un no koraļiem iegūtais porainais hidroksiapatīts (Browaeys, 2007). Laika gaitā ksenogēno materiālu granulas tiek rezorbētas un aizstātas ar kaulu. Pie vērša deproteinizētā kaula biomateriālu grupas pieder Bio-Oss, Geistlich Biomaterials, Šveice. Bio-Oss uzrāda labus rezultātus augmentētās zonas dimensiju stabilitātes ziṇā. Salīdzinājumā ar autogēnā kaula dobuma paaugstināšanas metodi tā ir daudz labāka (Lambert, 2011). Sajaucot Bio-Oss granulas ar dabīgo autogēno kaulu, tiek nodrošināta dimensiju stabilitāte un ātrāka jauna kaula veidošanās. Stabilitāti nodrošina biomateriālu granulas, bet dabīgā kaula fragmenti nodrošina ātrāku kaula veidošanos, jo satur osteogēnas šūnas 
(Pieri, 2012). Tomēr atsevišķi histologiskie pētījumi norāda, ka granulu rezorbcija notiek lēni vai arī tā nav vērojama vispār (Tadjoedin, 2003). Lietojot biomateriālu kopā ar kaula fragmentiem, pētījumos ir pierādīta laba implantātu stabilitāte un veiksmīga augmentācija (Hallman, 2005). In vitro pētījumi rāda, ka, lietojot ksenogēnos materiālus vienus pašus tie uzrāda labu šūnu diferencēšanos, bet vāju šūnu proliferāciju (Ayobian Markazi, 2011). Ksenogēno materiālu vājā rezorbcija nodrošina augmentētās zonas stabilitāti arī pret maksilārā dobuma repneimatizāciju (Kim, 2009).

Vērša kaula minerālu materiāli ir osteokonduktīvi. Pastāv viedoklis, ka arī pēc vērša kaula apstrādes, tas tomēr var saturēt augšanas faktorus, kas varētu nozīmēt, ka šie materiāli ir arī osteoinduktīvi. Gan vērša kaula minerālus saturošie kaula aizvietotāji, gan koraļu hidroksiapatīts, ja tiek izmantots augšžokḷa dobuma pamatnes paaugstināšanas operācijā, pēc 6 mēnešiem uzrāda vienādu kaula daudzumu augmentācijas zonā. Tomēr šo abu materiālu rezorbcija ir lēna, kas teorētiski var vājināt augmentētās zonas mehāniskās īpašības ilgtermiņā. Šo iemeslu dēl tikai šo abu materiālu lietošana augmentācijāa, bez dabīgā kaula piejaukuma, ir jāapsver un jāpārvērtē (Merkx, 2003). Uzskata, ka, pateicoties Bio-Oss fizikālajām un ķīmiskajām īpaš̄ībām, tas ir pielīdzināms mineralizētai cilvēka kaula matricei. Materiāla mikroskopiskā un makroskopiskā struktūra veido savstarpēji savienotus tuneḷus, kas sekmē osteogēno šūnu migrāciju (Tapety, 2004).

Pie ksenogēniem biomateriāliem pieder arī vērša kolagēns. Tas, lietojot to atsevišķi vai kopā ar plazmas trombocītiem, uzrāda labus kaula defekta reǵenerācijas rezultātus. Vērša kolagēna biomateriāls, piemēram, ir Colloss, Ossacur Medical Products GmbH \& Co, Vācija (Schlegel, 2004).

Lietojot no liellopiem iegūtus ksenogēnos materiālus pastāv, inficēšanās risks ar liellopu sūkḷveida encefalopātiju, sauktu arī par govju trakumsērgu. Cilvēkiem tā izraisa Kreicfelda - Jākoba saslimšanu, kuras ierosinātājs ir vīrusa daļa - prions, ko var saturēt inficēta liellopu audi (Reznick, 2004; Kolerman, 2012).

\subsubsection{Sintētiskie materiāli}

Tie ir sintēzes cel̦ā iegūti neorganiski, biosaderīgi, kaulaudus aizvietojoši materiāli. Šādā veidā ir iegūts hidroksiapatīts, $\beta$ - trikalcija fosfāts, polimēri un bioaktīva stikla granulas vai to kombinācijas (Browaeys, 2007). Hidroksiapatīts ir 
osteokonduktīvs (Salma, 2009), un to var lietot kā atsevišksu materiālu dobuma pamatnes paaugstināšanā (Canullo, 2012; Heinemann, 2009). In vitro pētījumi rāda, ka, lietojot sintētiskos materiālus vienus pašus, tie uzrāda labu šūnu diferencēšanos, bet vāju šūnu proliferāciju (Ayobian - Markazi, 2011). Citā pêtījumā konstatēts, ka 6-12 mēnešus pēc kaulu aizvietojošu materiālu lietošanas, sintētiskie materiāli uzrāda tikpat labus histologískos un volumetriskos rezultātus kā ksenogēnais materiāls Bio-Oss, Geistlich Biomaterials, Šveice (Cordaro, 2008; Wagner, 2012; Lindgren, 2012). Salīdzinājumā ar ksenogēno Bio-Oss sintētiskiem materiāliem piemīt labākas tilpuma stabilitātes īpašības. Četrus gadus pēc augšžokḷa dobuma pamatnes paaugstināšanas operācijas tika novērots 34\% tilpuma samazinājums lietojot Bio-Oss un $22 \%$ tilpuma samazinājums lietojot sintētisko materiālu, kura sastāvā bija $60 \%$ hidroksiapatīta un $40 \% \beta$ - trikalcija fosfăta. Autori to skaidro arī ar atšksirīgo granulu izmēru, kas Bio-Oss ir mazāks (Riachi, 2012).

4Bone SBS, Biomatlane, Francija, ir sintētisks kaulu aizvietojošs materiāls, kura sastāvā ir 60\% hidroksiapatīta un 40\% $\beta$ - trikalcija fosfāta. Izvērtējot augšžokḷa dobuma pamatnes paaugstināšanas operāciju rezultātus, kuras veiktas, izmantojot šo materiālu, ir secināts, ka materiāls ir biosaderīgs un osteokonduktīvs. Histoloǵiski izmeklējot biopsijas, kas tika iegūtas 9 mēnešus pēc augmentācijas, tika atrasti $26 \%$ jaunveidotā kaula, 27\% biomateriālu palieku un 46\% kaulu smadzeņu audu. Sievietēm jaunveidotais kauls un kopējā mineralizācija bija ievērojami zemāka kā vīriešiem (Kolerman, 2012). Salīdzinot citu sintētisko materiālu Straumann BoneCeramic, Institute Straumann AG, Šveice ar autogēno kaulu 9 mēnešus pēc dobuma pamatnes paaugstināšanas operācijas tika atzīmētas materiāla osteokonduktīvās un biosaderīgās īpašības, kā arī atzīts, ka to var izmantot šāda veida operācijās (Tosta, 2013). Savukārt Lindgrēns un citi (Lindrgren, 2012) atklāja, ka sintētiskam materiālam, kura sastāvā ir $20 \%$ hidroksiapatīta un $80 \% \beta$ - trikalcija fosfāta, rezultāti pēc augšžokḷa dobuma paaugstināšanas ir salīdzināmi ar autogēnā kaula lietošanas rezultātiem. Pieaugot hidroksiapatīta daudzumam sintētiskajā materiālā kaula dz̄īšanas potenciāls mazinās, bet dimensionālā stabilitāte uzlabojas (Jensen, 2009).

Bioaktīvā stikla granulas ir materiāls, kas rezorbējas. Stikla granulas kalpo kā nelielas kaula reǵenerācijas kameras. Ir pierādīts, ka bioaktīvā stikla granulu materiāliem piemīt gan osteokonduktīvas, gan kaulu reǵenerējošas īpašības (Merkx, 2003). 
$\beta$ - trikalcija fosfāts ir sintētisks materiāls, kas nodrošina matrici jaunā kaula veidošanai, un ir lēni, bet pilnībā rezorbējams. Pēc 6 mēnešiem augmentētajā zonā ir vērojams līdz pat 30\% jauna kaula. Šādi rezultāti nodrošina, ka, iespējams, nav jāpievieno dabīgā kaula fragmenti (Merkx, 2003). Citi autori norāda, ka $\beta$ - trikalcija fosfātu saturošie materiāli uzrāda ātru jauna kaula veidošanos un materiāla rezorbciju, kas ne vienmēr ir vēlams veicot augšžokḷa dobuma pamatnes paaugstināšanu. Šos materiālus rekomendē lietot, kad ir jāaizpilda kaula defekts, piemēram, pēc zoba ekstrakcijām (Jensen, 2006). Pie šīs grupas materiāliem pieder Cerasorb, Curasan Pharma GmbH, Vācija.

Dažreiz kaulu aizvietojošiem materiāliem, lietojot augšžokḷa dobuma paaugstināšanas operācijā, tiek pievienota ar trombocītiem bagātināta plazma, no trombocītiem atvasināts augšanas faktors vai citi faktori. Tas tiek darīts, lai samazinātu dzīšanas laiku, kā arī lai paātrinātu kaula veidošanos transplantētajos audos (Browaeys, 2007).

Citi autori pēta un praksē izmanto dobuma pamatnes paaugstināšanu bez biomateriālu pielietojuma - zem paceltās Šneidera membrānas ļaujot veidoties asins receklim, kura vietā pēc tam fiziologiski izveidojas kaulaudi (Lundgren, 2004). Tomēr pētījumi rāda, ka šāda dobuma pamatnes paaugstināšana nav stabila un tā pakḷaujas dobuma repneimatizācijas spiedienam un rezorbcijai (Lambert, 2011).

Augšžokḷa dobuma pamatnes paaugstināšanai ir pieejami daudzi dažādi biomateriāli. Tiem ir atšķirīgs ķīmiskais sastāvs un fizikālie parametri. Literatūrā ir pieejamas daudzas publikācijas, kas salīdzina jau esošos materiālus savā starpā, kā arī pēta jaunus pieejamos materiālus. Tomēr publikācijas parasti aptver nelielas pētījumu grupas, un to pētījumu metodologija ir atšķirīga. Tādēl joprojām nav izstrādātas konkrētas vadlīnijas vai rekomendācijas, kurš biomateriāls ir labāks par citiem. Arī tas, ka joprojām ir tik daudz atšksirīgu pētījumu šajā jomā, apliecina nevienprātību dažādu materiālu pielietojuma ziṇā. Jādomā, ka ideāls materiāls vēl nav atrasts un diez vai vispār pastāv. Līdz ar to, tas, kādu materiālu lietot, ir atkarīgs no katras situācijas, ķirurga pieredzes un zināšanām un pieejamajiem materiāliem. Autogēnais pacienta kauls ir augšžokḷa dobuma pamatnes paaugstināšanas „zelta standarts”, tomēr tas, vai lietot autogēnu kaulu vai kādu no daudzajiem pieejamajiem biomateriāliem, paliek ārstējošā ārsta un pacienta savstarpējās komunikācijas ziṇā (Nkenke, 2009). 


\subsection{Literatūras apskata kopsavilkums}

Apkopojot literatūras avotu datus, var izdarīt šādus secinājumus.

1. Augšžoklis un tā struktūras dzīves laikā mainās kā eksogēnu, tā arī endogenu faktoru ietekmē.

2. Augšžokḷa dobuma pamatnes paaugstināšanas operācija ir droša un efektīva metode atrofisku reziduālu augšžokḷu mugurējās daļas paaugstināšanai, lai varētu ievietot zobu implantātus. Sekmīgam rezultātam nepieciešamas operācijas veicēja iemaņas un pieredze, kā arī radiologísks izmeklējums, kas palīdz plānot operācijas gaitu un tādējādi novērst vai mazināt iespējamo komplikāciju daudzumu un smagumu.

3. Radioloǵiskie izmeklējumi, īpaši, trīsdimensiju attēlu diagnostika, novērtēta gan kā operācijas plānošanas, gan kā pēc operācijas kontroles metode. Dažādas radiologiskas atradnes augšžokḷa dobumā pirms operācijas var būt pagaidu kontrindikācijas ADPP veikšanai. Savukārt pēcoperācijas KSDT kontrole veicama aizdomu gadījumā par operācijas komplikācijām.

4. ADPP operācijas gaitā tiek pielietoti dažādi kaulu aizvietojošie biomateriāli. Par „zelta standartu” tiek uzskatīts pacienta kaula pārstādīšana - autotransplantācija, tā kaula konduktivitātes un pieaugšanas dēḷ. Tomēr autotransplantātu n̦emšana pacientam ir nepatīkama, un autotransplantātiem ir vērojama izteikta, neprognozējama, strauja rezorbcija. Tādēḷ tiek meklēti dažādi kaulu aizvietojoši biomateriāli, kas tiek iegūti gan no cilvēku līķiem, gan pilnībā sintezēti laboratorijās, gan arī no dzīvnieku izcelsmes audiem. Šobrīd neviens no minētajiem daudzajiem pieejamajiem biomateriāliem neuzrāda labākus rezultātus kā citi. Par to liecina daudzie literatūrā pieejamie pētījumi. Līdz ar to tas, kādu biomateriālu katrā situācijā izvēlēties, ir ārsta, pacienta un materiāla pieejamības jautājums.

5. Literatūrā ir dati par dažādiem radiologiskiem pētījumiem saistībā ar ADPP, bet tie parasti ir sadalīti, neapvienojot visas radioloğiskās atradnes vienā pētījumā. Par radiologisko izvēles metodi augšžokḷa dobuma pamatnes paaugstināšanas operācijas plānošanā un ilgtermiņa izvērtēšanā tiek uzskatīta trīsdimensiju koniskā stara datora tomogrāfija. 


\section{MATERIĀLI UN METODES}

Pētījumā tika iekḷauti 59 pacienti/ 78 augšžokḷu dobumi, kuriem laika posmā no 2008. gada līdz 2012. gadam Rīgas Stradiņa universitātes (RSU) Stomatoloǵijas institūta Mutes, sejas un žokḷu diagnostiskās radioloǵijas nodạ̦ā tika veikts trīs dimensiju datora tomogrāfijas - KSDT - izmeklējums pirms augšžokḷa dobuma pamatnes paaugstināšanas (ADPP) operācijas pielietojot biomateriālus. Deviṇpadsmit pacientiem (32,2\%) tika veikta abpusēja augšžokḷu dobumu paaugstināšanas operācija, bet nevienā no gadījumiem tā netika veikta vienlaicīgi abās pusēs. Augšžokḷa dobuma paaugstināšanas operācija tika veikta RSU Stomatologijas Institūta Mutes, sejas un žokḷu ķirurǵijas klīnikā. Kopumā tika atlasīti 150 šādu pacientu, kuriem bija pagājis vismaz gads pēc ADPP operācijas. Pacientiem tika izsūtīti uzaicinājumi veikt atkārtotu kontroles KSDT izmeklējumu (1. pielikums). No 150 pacientiem uzaicinājumam atsaucās minētie $59(37,1 \%)$ pacienti, kuri tad arī tika iekḷauti pētījuma grupā. Par pētījuma subjektiem tika noteikti 78 augšžokḷa dobumi, kuros tika veikta pamatnes paaugstināšanas operācija pielietojot kaulu aizvietojošus biomateriālus

Pacientu radiolog̣iskie un klīniskie dati tika iegūti, apkopoti un izmantoti saskaņā ar RSU Ētikas komitejas atļauju (lēmums pieņemts 16.12.2010.) (2. pielikums). Pētījumā netika ñemts vērā pacienta vispārējais veselības stāvoklis izmeklējumu un operācijas laikāa kā arī zobu zaudējumu laiks pirms ADPP un smēķēšanas faktors.

No RSU Stomatolog̣ijas institūta datu bāzes kontroles grupai tika atlasīti 24 pacienti, kuriem tika veikta zobu implantātu ievietošana augšžokļa mugurējās daļas alveolārajā izaugumā bez augšžokḷa dobuma pamatnes paaugstināšanas ar kaulu aizvietojošiem biomateriāliem. Šie pacienti tika iekḷauti kontroles grupā, ja viņiem bija veikts izmeklējums pirms un pēc implantācijas operācijas. Trīspadsmit gadījumos (54,16\%) implantācija tika veikta abpusēji, līdz ar to kontroles grupas pārstāvji bija 37 augšžokļa mugurējās daļās ievietotie implantātu gadījumi. 


\subsection{Radiologiiskā izmeklējuma apraksts}

Pirms operācijas plānošanā un pēc operācijas novērtēšanā radioloǵiski tika izmantota RSU Stomatologijas institūta KSDT iekārta I-CAT Next Generation, Imaging Science, ASV (5.1. attēls).
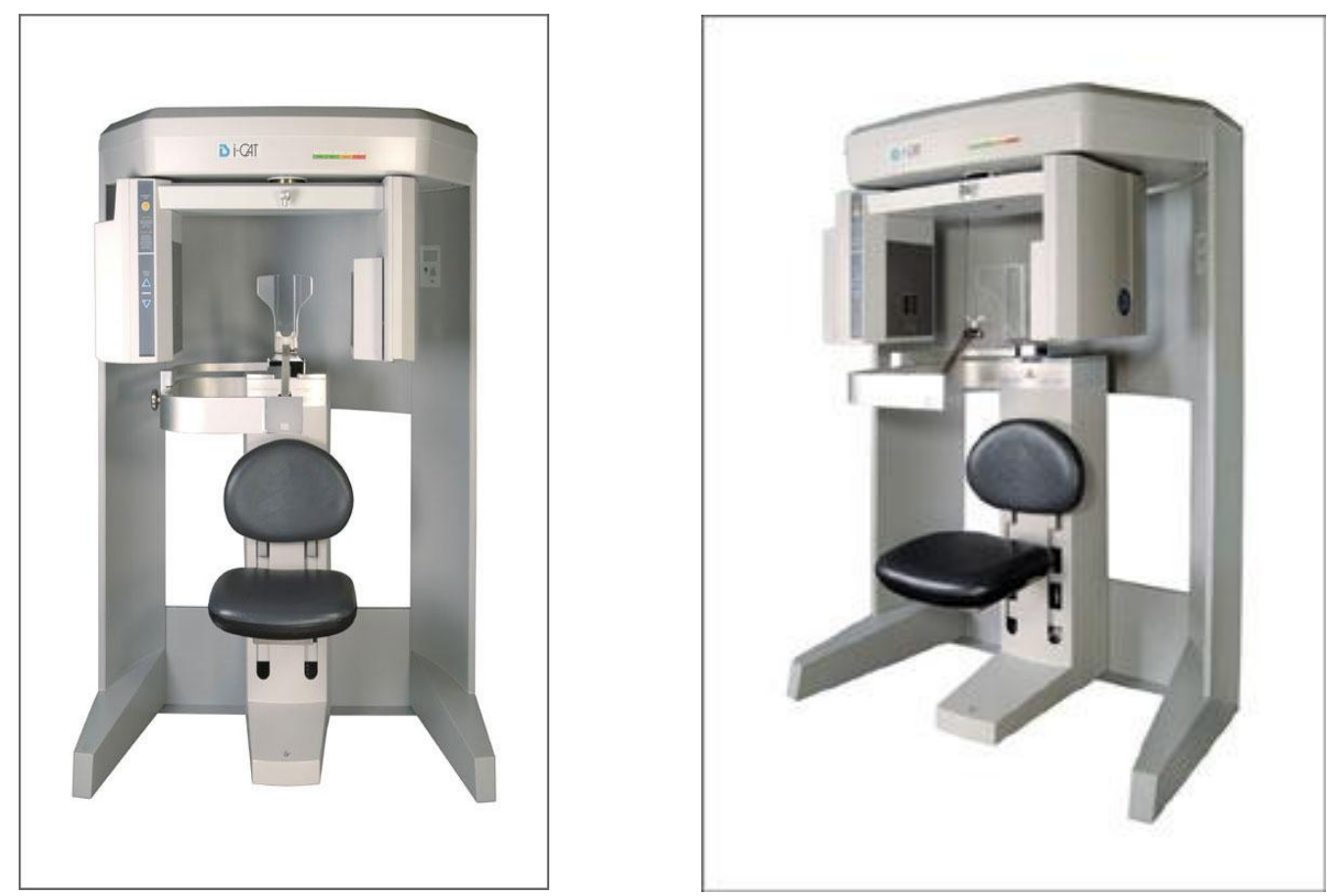

5.1. att. I-CAT Next generation, Imaging Science, ASV

Visi pacienti tika izmeklēti pēc vienota protokola. Pacientu žokḷu skenēšana tika veikta $16 \mathrm{~cm}$ diametrā un $13 \mathrm{~cm}$ augstumā 8-9 sekundes ar jaudu $120 \mathrm{~kW}, 5 \mathrm{~mA}$. Attēli tika iegūti, izmantojot 0,3 vokseḷu (trīsdimensiju attēla tilpuma mērvienība) lielumu. Attēli tika apstrādāti un rekonstruēti ar iekārtas programmatūru ExamVision 1.9, KaVo, Vācija (5.2. attēls). 


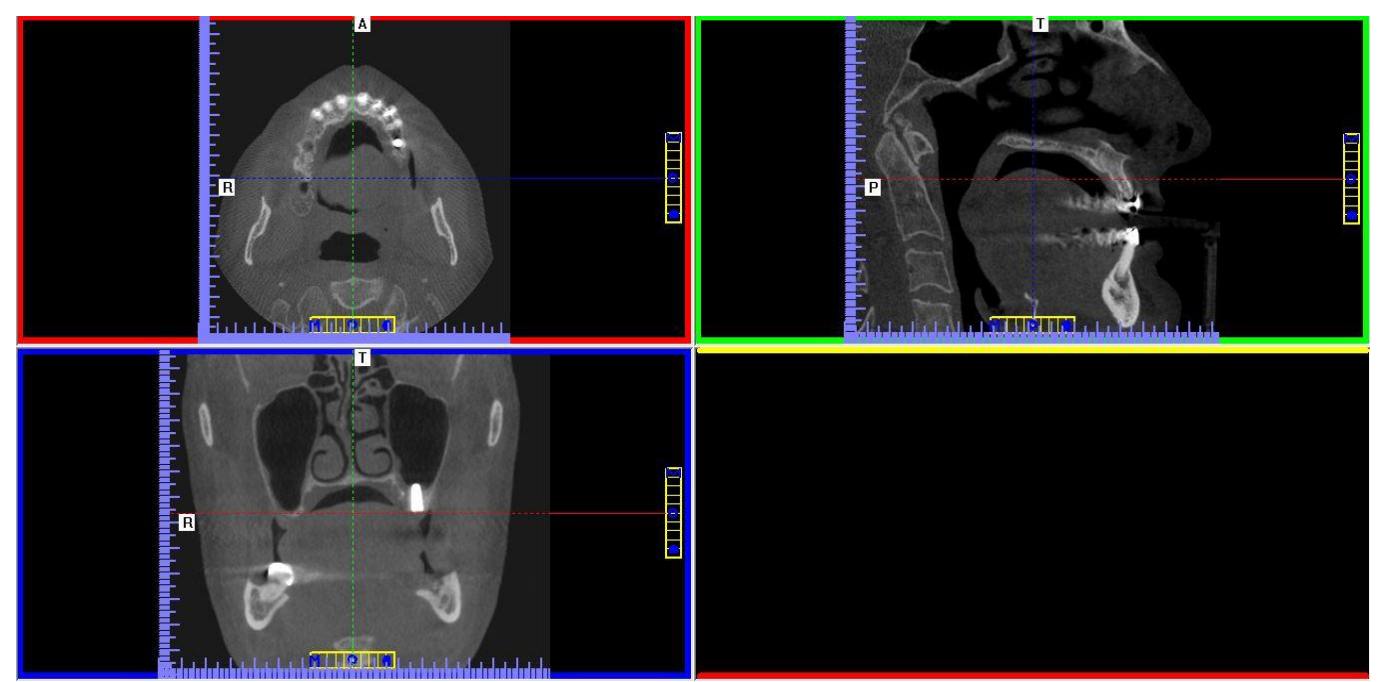

5.2. att. Exam Vision 1.9 KSDT rekostruētie trīs dimensiju attēli

Pirms mērījumu veikšanas attēls tika pozicionēts tā, lai cieto aukslēju plakne būtu paralēla grīdai, bet sagitālā plakne būtu perpendikulāra tai. Sagitālā plakne tika iezīmēta caur deguna starpsienu, augšžokḷa cieto aukslēju šuvi un augšžokḷa centrālo incizīvu kontaktpunktu. Mērījumus veica viens ārsts. Pirms operācijas izmeklējumos mērījumi tika veikti koronārā griezumā, kurā redz augšžokḷa dobuma fizioloǵisko atveri (5.3. attēls).

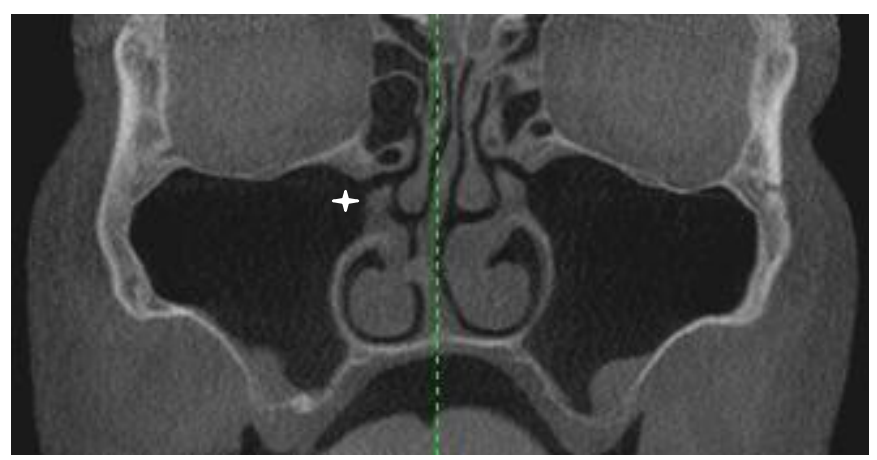

5.3.att. KSDT koronārais griezums. Ar zvaigznīti atzīmēta kreisās puses augšžokḷa dobuma fiziologisk $\bar{a}$ atvere

Tika veikti lineārie mērījumi: alveolārā kaula augstuma un platuma mērījumi pirms operācijas. Mērījumi tika reǵistrēti milimetros (mm) (5.4. attēls). 


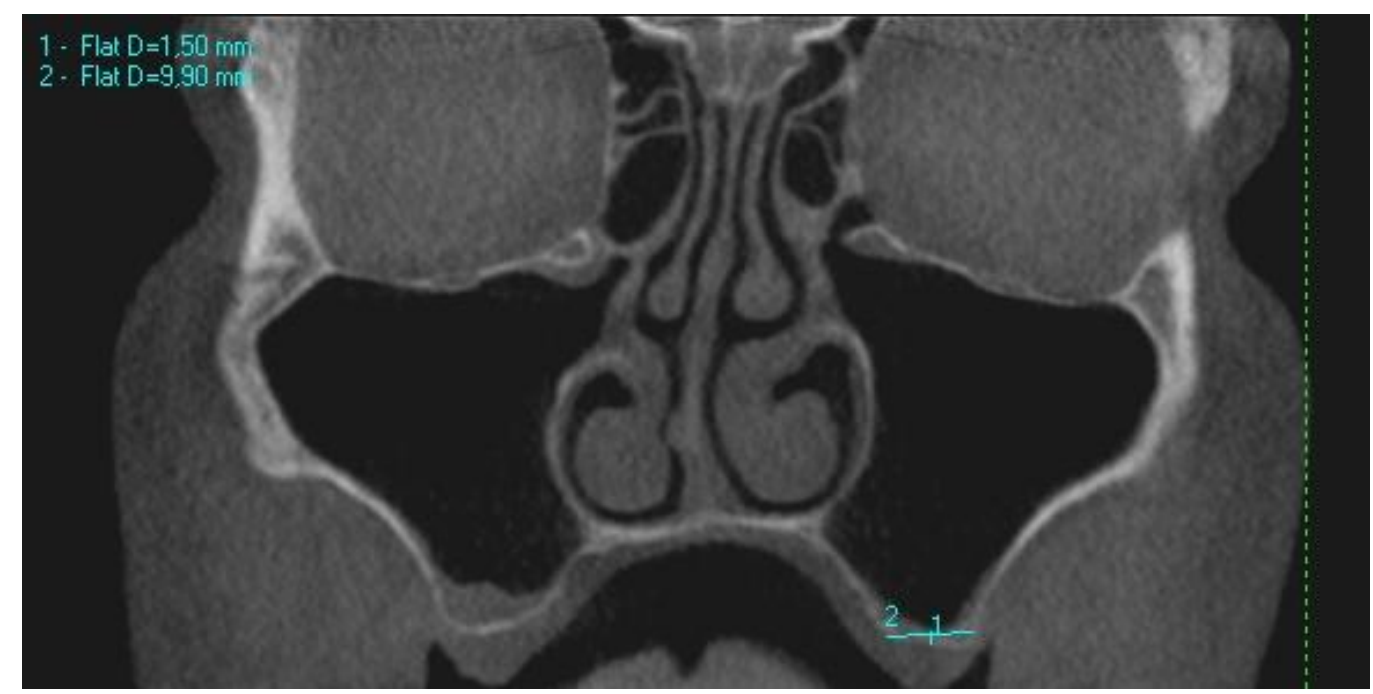

\section{4. att. Kaula augstuma (1) un platuma (2) mērījums. KSDT koronārs griezums}

Pirms operācijas radioloǵiskajos izmeklējumos tika noteikta attēla vokseļa nomelnējuma līmeņa vērtība vietā, kur kaulā paredzēts veikt ADPP. Iekārta šo mērījumu uzrāda Haunsfîlda vienībās (HU), kuras tika 1:1 pārveidotas radiologiskā nomelnējuma līmeņa vērtības vienībās - VV (5.5. attēls).

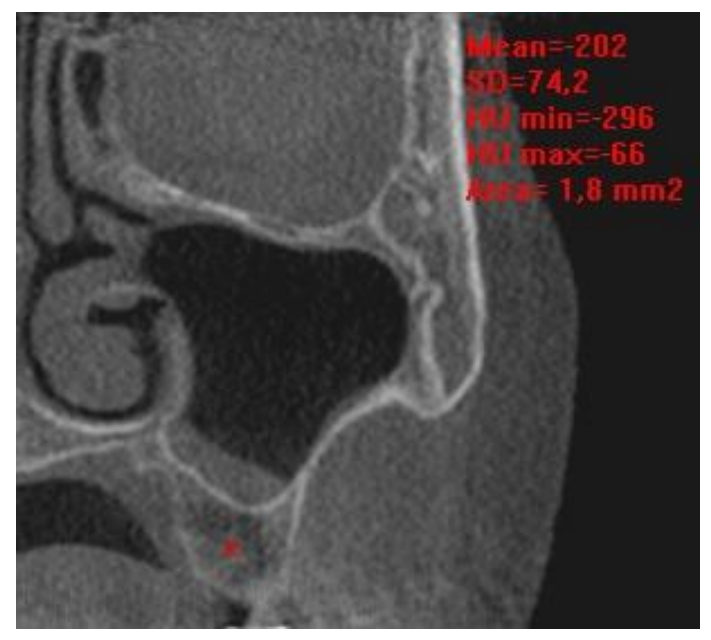

\section{5. att. Attēla nomelnējuma līmeņa noteikšana alveolārajā kaulā} pirms augmentācijas operācijas. KSDT koronārā griezuma dạ̣a

Attēla nomelnējuma līmen̦a vērtības noteikšana tika veikta $0,8-1,3 \mathrm{~mm}^{2}$ lielā laukā.

Tika radioloǵiski izmeklēts arī augšžokḷa dobuma stāvoklis - noteikts, vai radiologiiski ir konstatējamas patologijas: gḷotādas sabiezējums (mm) (5.6. attēls), 


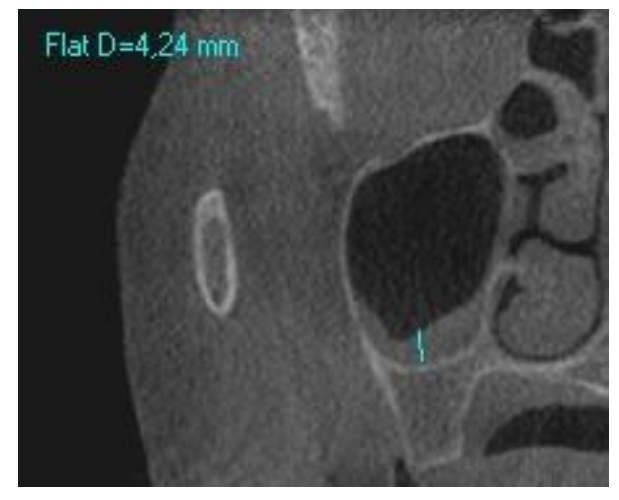

5.6. att. KSDT koronāra griezuma daḷa. Gḷotādas sabiezējuma mērījums labās puses augšžokḷa dobumā

gḷotādas sabiezējuma veids: nav sabiezēta, sabiezēta bazāli (5.7. attēls),

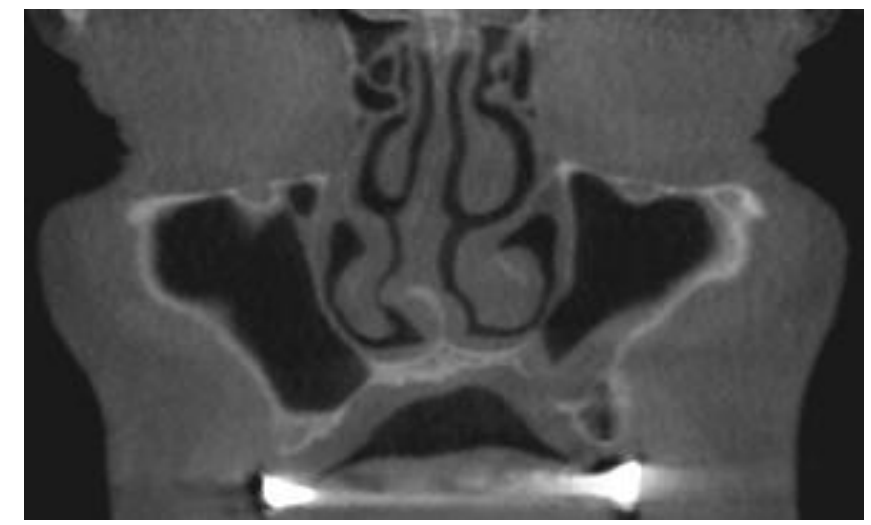

5.7. att. KSDT koronārais griezums. Labās puses augšžokḷa dobums, sabiezētu gḷotādu nekonstatē; kreisās puses augšžokḷa dobumā bazāli redz sabiezētu gḷotādu

cirkulāri (5.8. attēls) 


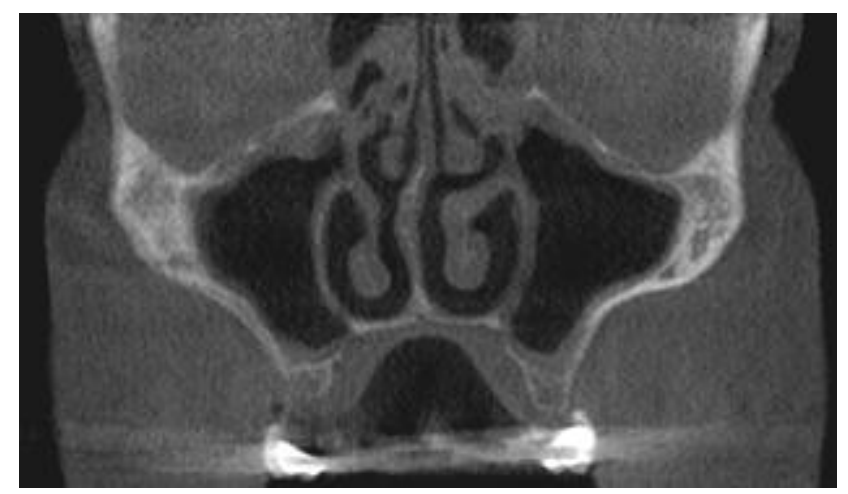

5.8. att. KSDT koronārs griezums. Abpusēji cirkulāri sabiezēta gḷotāda cistiski (5.9. attēls),

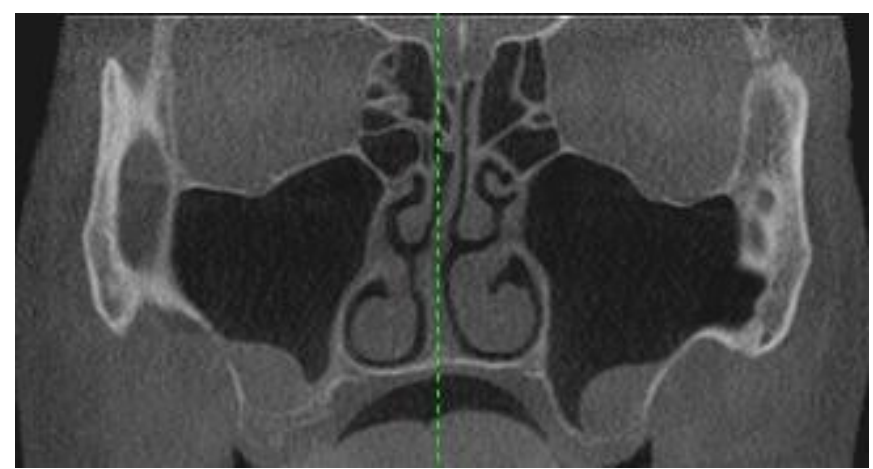

5.9.att. KSDT koronārs griezums. Abpusēji cistiski sabiezēta gḷotāda neregulāri (5.10. attēls),

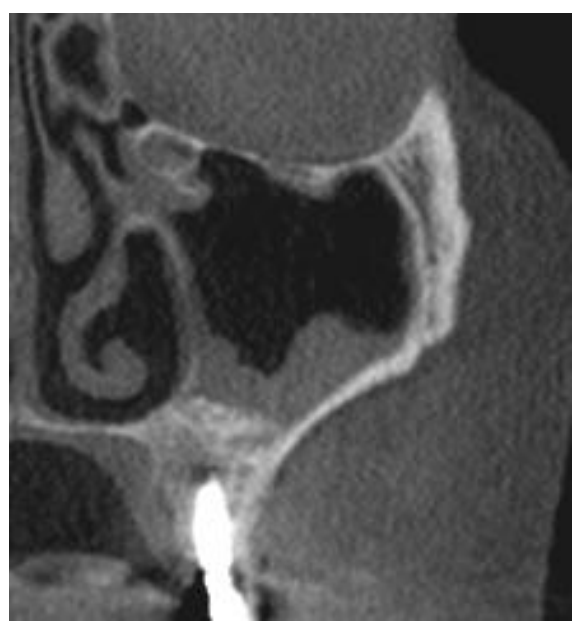

5.10. att. KSDT koronārs griezums. Neregulāri sabiezēta gḷotāda 
pilnībā aizēnots dobums(5.11. attēls),

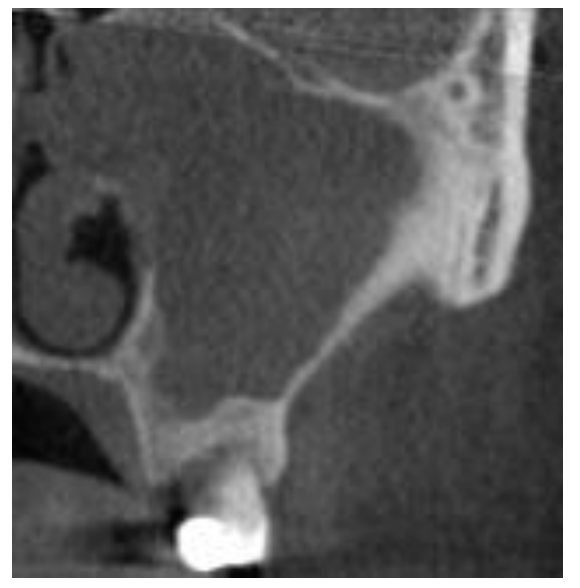

5.11. att. KSDT koronārs griezums.

Pilnībā aizēnots kreisās puses augšžokḷa dobums

fiziologiiskās atveres obstrukcija ir/nav (5.12. attēls),

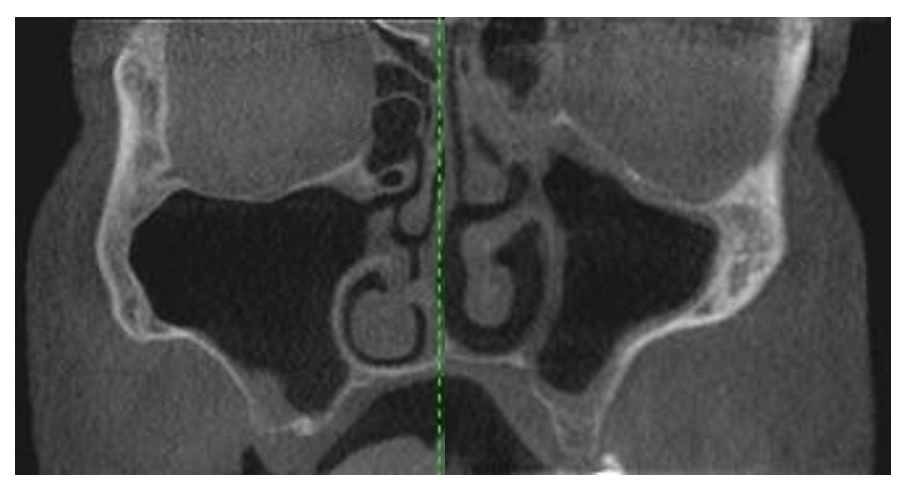

5.12. att. KSDT koronārs griezums. Labās puses augšžokḷa dobumā fizioloğiskā atvere brīva, kreisā - obturēta

papildus atvere ir/nav (5.13. attēls), 


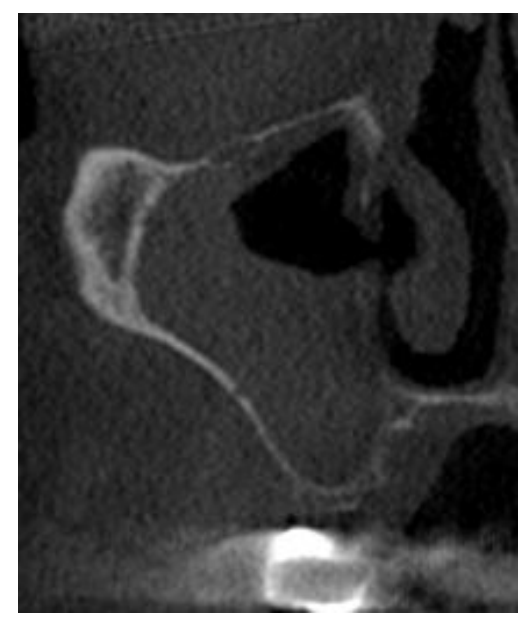

5.13. att. KSDT koronārs griezums. Labās puses augšžokḷa dobuma mediālajā sienā redz papildus atveri, kas atveras uz deguna dobuma vidējo eju

pneimatizēta deguna dobuma vidējā gliemežnīca - concha bullosa - ir/nav (5.14. attēls).

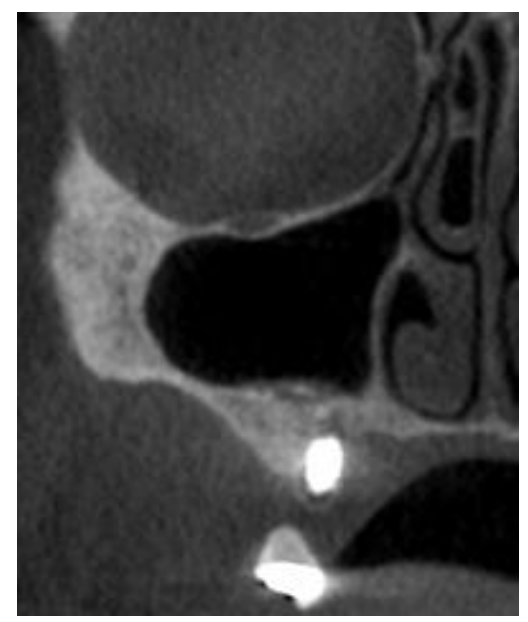

5.14. att. KSDT koronārs griezums. Labās puses deguna dobuma ejas vidējās gliemežnīcas pneimatizācija - concha bullosa

Pirms operācijas tika mērīts arī augšžokḷa dobuma tilpums $\left(\mathrm{mm}^{3}\right)$. Dobuma tilpums tika mērīts ar Dolphin Imaging 3D (Dolphin Imaging \& Management Solutions, ASV) programatūru.

Pēc operācijas radioloǵiskie izmeklējumi tika pozicionēti kā pirms operācijas. Mērījumi tika veikti koronārajā griezumā caur implantātu, kas atrodas vistuvāk 
augšžokḷa dobuma atverei. Tika veikti augšžokḷa dobuma augmentētās zonas augstuma, platuma (5.15. attēls) un garuma lineārie mērījumi milimetros (5.16. attēls).

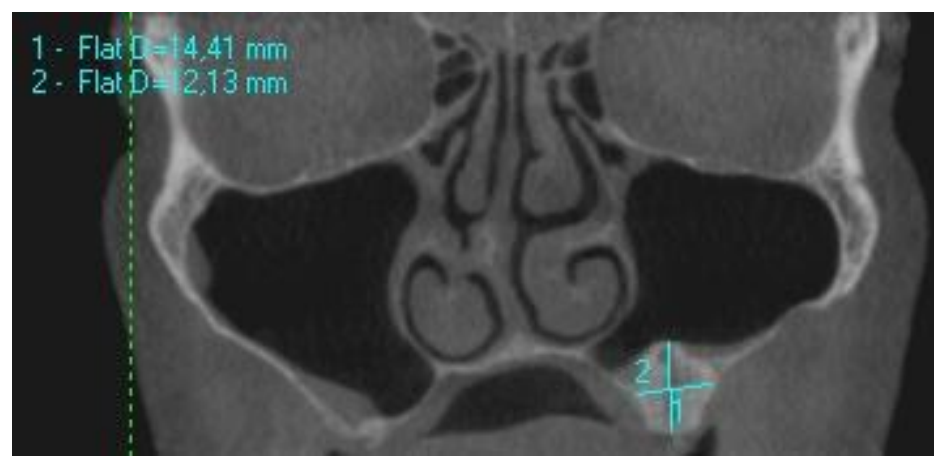

5.15. att. Augmentētās zonas augstuma un platuma mērījums KSDT koronārajā griezumā

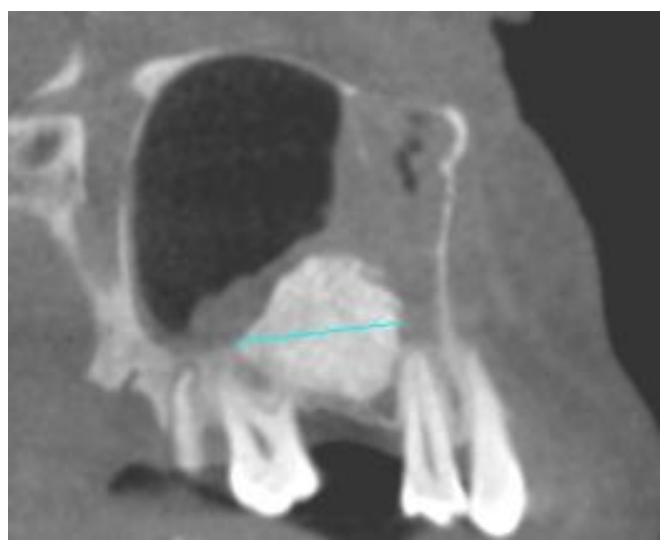

5.16. att. Augmentētās zonas garuma mērījums KSDT sagitālajā griezumā

Piecos punktos ap implantātu: bukāli kaulā (BK), bukāli augmentētajā zonā (BAZ), apikāli (AP), palatināli augmentētajā zonā (PAZ), palatināli kaulā (PK), tika reǵistrēta attēla nomelnējuma līmeņa vērtība VV (5.17. attēls). 


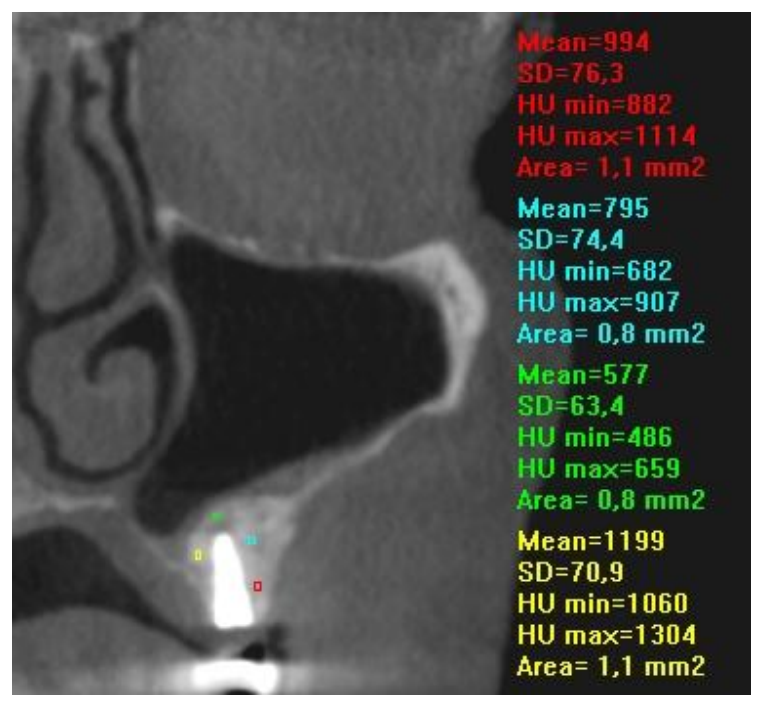

\subsection{7. att. Radiologiskā nomelnējuma līmeņa vērtības mērījumi} augšžokḷa dobuma augmentētajā zonā

Ja tika veikta divu etapu operācija, ar augšžokḷa dobuma pamatnes paaugstināšanai sekojošu zobu implantātu ievietošanu, tad mērījumi tika veikti divos punktos koronārajā griezumā, augmentētās zonas vidusdaļā (AZ) un kaulā (K) (5.18. attēls).

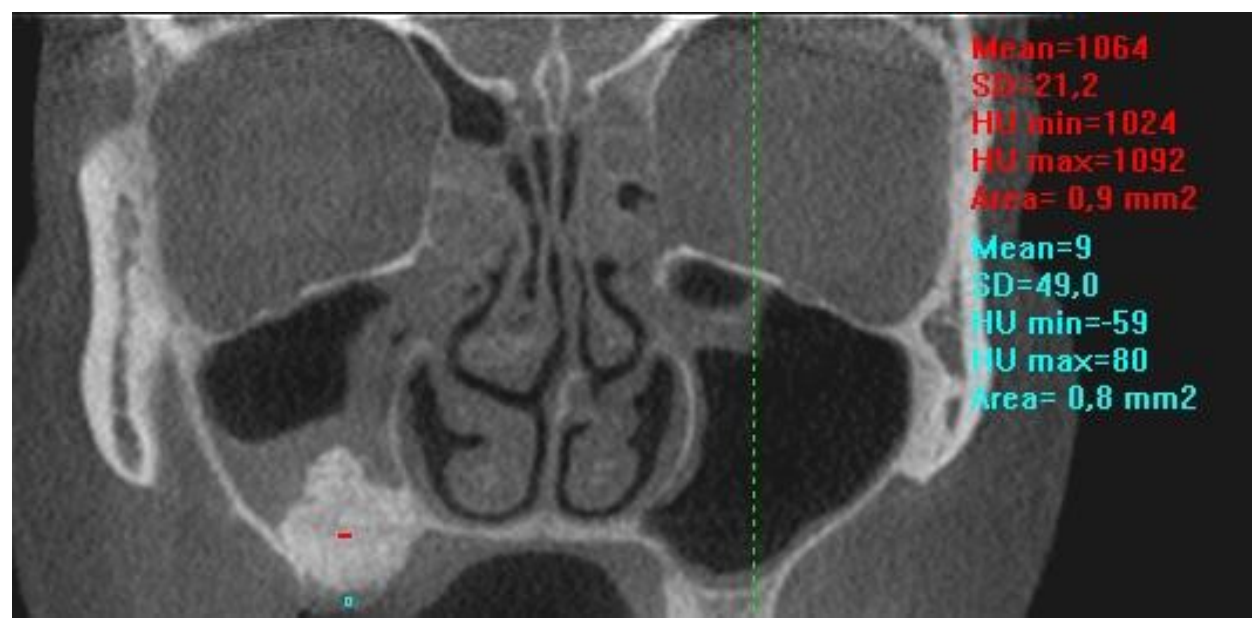

5.18. att. Radioloğiskā nomelnējuma līmeṇa vērtības mērījumi augšžokḷa dobuma augmentētajā zonā

Līdzịgi kā pirms operācijas arī pēc operācijas tika radiologiski izmeklēts augšžokḷa dobuma stāvoklis - noteikts vai ir radioloǵiski konstatējamas patoloğijas: 
gḷotādas sabiezējums (mm), g̣̦otādas sabiezējuma veids (nav sabiezēta, bazāli, cirkulāri, cistiski, piln̄̄bā aizēnots dobums), fizioloğiskās atveres obstrukcija ir/nav, papildus atvere ir/nav, pneimatizēta deguna dobuma vidējā gliemežnīca - concha bullosa ir/nav. Pēc operācijas tika mērīts arī augšžokḷa dobuma tilpums $\left(\mathrm{mm}^{3}\right)$.

Kontroles grupā tika iekḷauti pacienti, kuriem tika izdarīts radioloǵisks KSDT izmeklējums pirms un pēc implantācijas operācijas bez augšžokḷa dobuma paaugstināšanas operācijas. Laika posms pēc operācijas šai grupai netika izdalīts kā atsevišķss atlases kritērijs. Attēla nomelnējuma līmeņa vērtība tika noteikta kaulā pirms operācijas (VV) un pēc operācijas 5 punktos ap implantātu - bukāli kaula mala (BKM), bukāli kauls kraniāli (BKK), apikāli (AP), palatināli kauls kraniāli (PKK), palatināli kaula mala (PKM) (5.19. attēls)

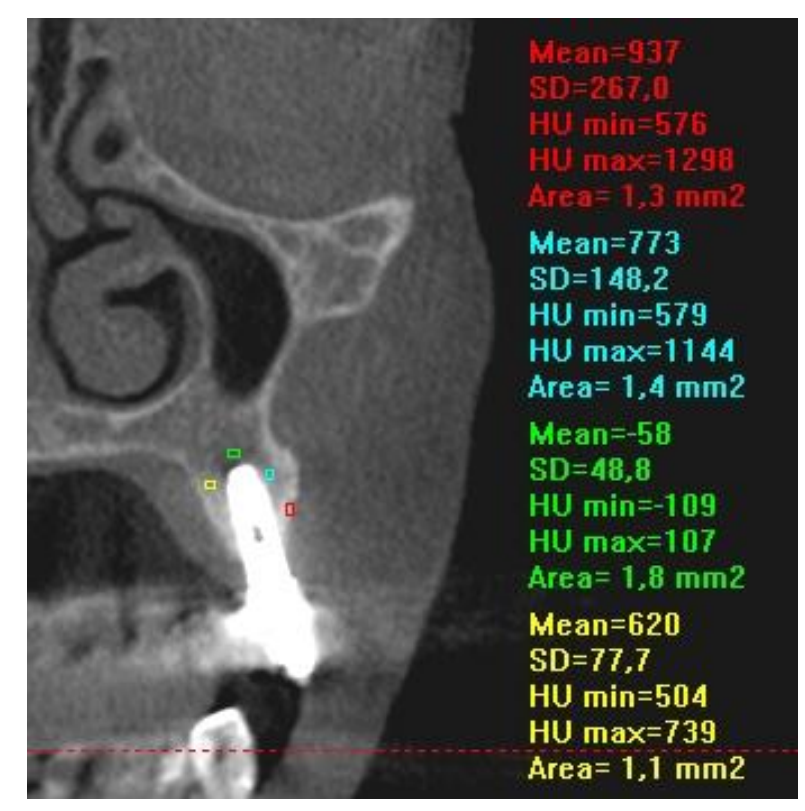

\subsection{9. att. Attēla nomelnējuma līmeņa vērtības mērījumi ap implantātu kontroles grupai}

Kontroles grupa tika izveidota, lai novērtētu implantātu veidojošo artefaktu un kaulu aizvietojošo biomateriālu ietekmi uz apkārtējo audu struktūras radiologisiski nosakāmām izmaiṇām.

Iegūtie mērījumi tika reǵistrēti un sagrupēti $M S$ Excell tabulā, pēc tam statistiski apstrādāti. 


\subsection{Klīnisko un demogrāfisko datu ieguves metode}

Atlases kritērijiem atbilda tikai tie pacienti, kuriem bija pagājis vismaz gads pēc operācijas, kad tika veikts otrs, atkārtots radioloǵisks izmeklējums. Lai precizētu operācijas veikšanas laiku, tika izmantots Mutes, sejas un žokḷu ķirurğijas klīnikas operāciju reǵistrāciju žurnāls. Pēc reǵistrācijas žurnāliem tika noteikti pacienta demogrāfiskie dati operācijas veikšanas laikā, lokalizācija, kurā pusē operācija veikta, izmantotais kaulu aizstājošais materiāls. Iegūtie dati tika apkopoti un registrēti $M S$ Excell tabulā, pēc tam statistiski apkopoti.

\subsection{Datu apstrādes statistiskās metodes}

Datu statistiskā apstrāde tika veikta, izmantojot datorprogrammas SPSS v.15.0 un Microsoft Office Excel v.11.

Pacientu parametru raksturošanā izmantotas vispārpieņemtās aprakstošās statistikas metodes - kopsavilkuma tabulas kopā ar stabiṇu, joslu grafikiem vai histogrammām. Tika izvērtēti centrālās tendences rādītāji (vidējais aritmētiskais, mediāna) un izkliedes rādītāji - standartnovirze (SD), standartkḷūda (SE), kā arī 25. un 75. percentīle.

Testu rezultātu nozīmīgums ir izvērtēts ar 5\% statistiskās kḷūdas varbūtību, tādējādi, ja testu rezultātos p-vērtība bija mazāka par 0,05, testu rezultāti tika atzīti par statistiski nozīmīgiem.

Atšķirību novērtēšanā tika izmantoti vairāki statistiskie testi - ja proporcionālie dati bija pakḷauti normālajam (Gausa) sadalījumam, kvantitatīvo atšķirību analīzē starp divām un vairākām grupām tika izmantota dispersiju analīze (ANOVA), starp divām grupām - Stjudenta $\mathrm{t}$ - tests. Ja dati nebija pakḷauti normālajam sadalījumam, papildus tika pielietots neparametriskais Manna - Vitnija U - tests divu izlašu salīdzināšanai vai Kruskola - Valisa H - tests divu un vairāk izlašu salīdzināšanai. Proporcionālo datu atbilstība normālajam sadalījumam tika noteikta, izmantojot Kolmogorova - Smirnova testu.

Pacientu grupu kvalitatīvo atšksirību izvērtēšanā tika izmantots Pīrsona hī kvadrāta $\left(\chi^{2}\right)$ tests un papildus aprēksināti precizētie atlikumi, bet $2 * 2$ tabulās - Fišera eksaktais tests (Bulman, 2000; Rowntree, 2000; Altman, 1996). 
Saistības starp main̄̄gajiem tika noteikta pielietota korelācijas analīzi. Korelācijas rēķināšanas metode bija atkarīga no mainīgo skalas. Ja mainīgie bija mērīti lineārajā skalā un atbilda normālajam sadalījumam, saistības noteikšanā tika pielietots Pīrsona korelācijas tests. Ja vienam no mainīgajiem bija ordinālā skala, tika pielietots neparametrisks Spīrmena rangu korelācijas tests. Korelācijas rezultāti tika interpretēti šādi:

0 = korelācija nepastāv;

$0-0,2$ = loti vāja korelācija;

0,2-0,5 = vāja korelācija;

$0,5-0,7=$ vidēja korelācija;

$0,7-0,9=$ augsta korelācija;

$0,9-1,0=$ l,oti augsta korelācija.

Korelācija tika atzīta par nozīmīgu, ja p $\leq 0,05$ (vai $\leq 5 \%$ ) (Rowntree, 2000; Altman, 1996).

Neatkarīgo mainīgo ietekmes stipruma un nozīmīguma noteikšanā tika izmantota lineārā regresija (Altman, 1996). 


\section{REZULTĀTI}

\subsection{Demogrāfiskie un klīniskie rezultāti}

Apkopojot demogrāfiskos datus tika konstatēts, ka no 78 pêtījuma grupā iekļautiem augšžokḷa dobumiem 51 (65,4 \%) bija sieviešu dzimuma pacientēm, bet pārējie 27 (34,6\%) bija vīriešiem (6.1. attēls).

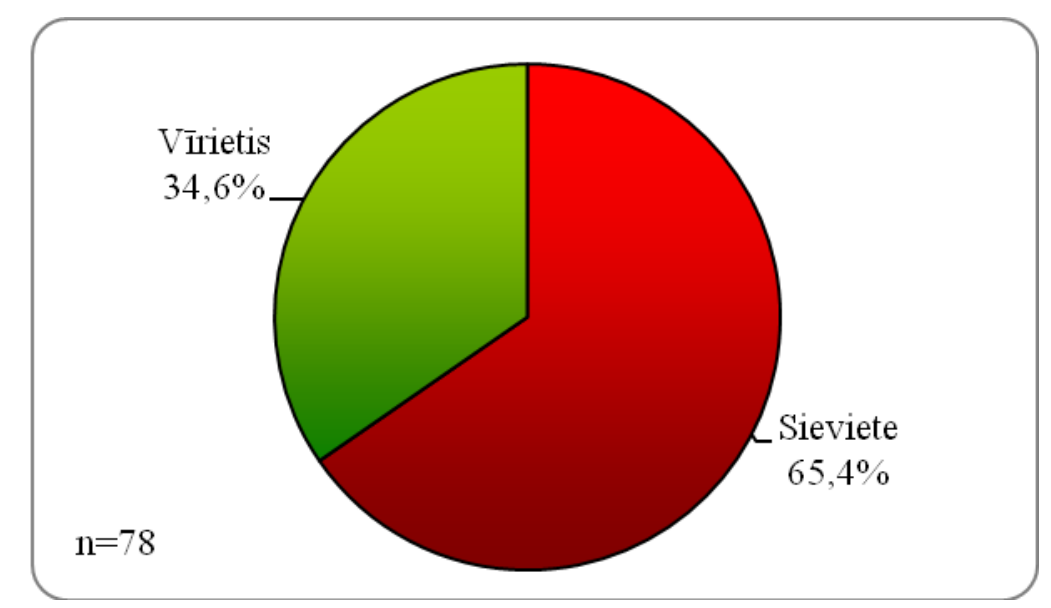

\section{1. att. Pētījuma grupas dzimumu sadalījums}

Augšžokḷa dobuma pamatnes paaugstināšanas operācijas laikā vidējais vecums bija 50,88 SD \pm 9,82. Mazākais vecums bija 28 gadi, bet vecākā pêtījumā iekḷautā pacienta vecums operācijas laikā bija 78 gadi. Pêtījumā iekḷauto sieviešu subjektu vidējais vecums bija 49,39 $\mathrm{SD} \pm 10,16$, bet vīriešu vidējais vecums bija 53,70 $\mathrm{SD} \pm 8,63$ (6.2. attēls). 


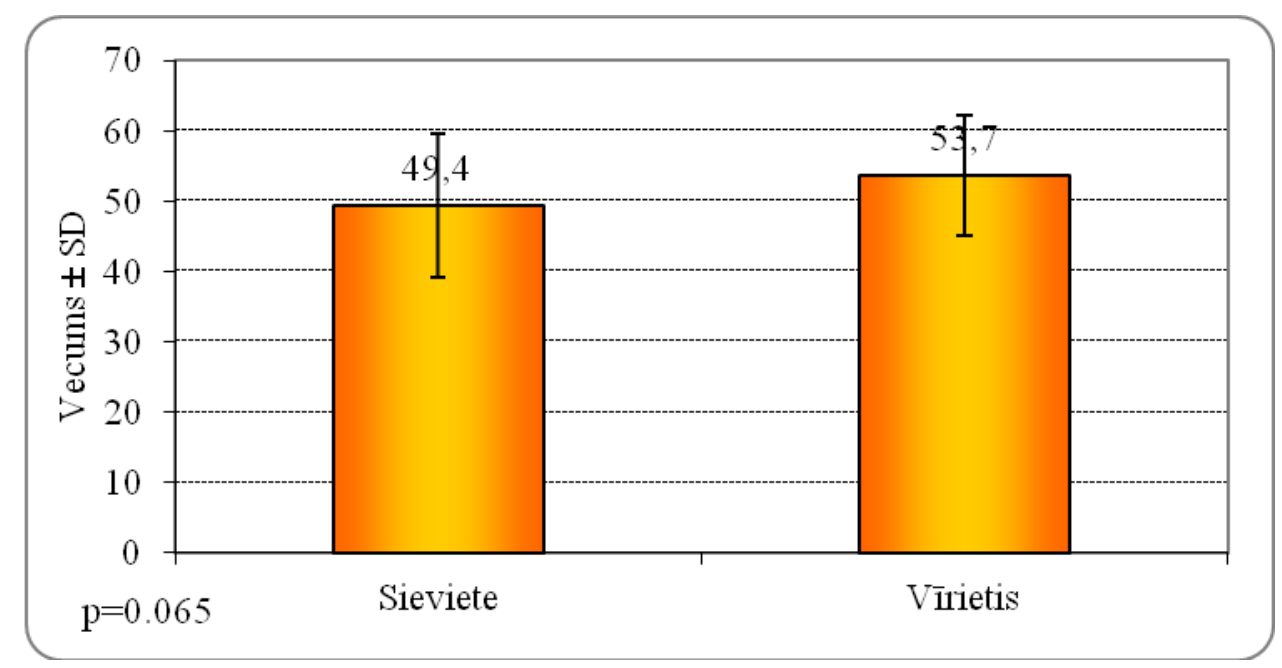

6.2. att. Pētījuma grupas vecums pēc dzimumu sadalījuma

Atlases kritērijs, lai iekḷautu pacientu pētījumā, bija atkārtots, kontroles KSDT radiologiiskais izmeklējums vismaz vienu gadu pēc ADPP operācijas ar kaulu aizvietojošu biomateriālu lietošanu. Ilgākais reǵistrētais laiks pēc operācijas līdz atkārtotam KSDT izmeklējumam bija 3,92 gadi. Vidējais laiks pēc operācijas līdz atkārtotam KSDT izmeklējumam bija 2,06 SD $\pm 0,749$ gadi. Statistiski ticamas atšķirīibas starp dzimumiem un laiku, kāds pagājis līdz kontroles KSDT izmeklējumam, netika konstatētas (ANOVA, $\mathrm{p}=0,984$ ).

Analizējot pētîjumā iekḷautos gadījumus tika konstatēts, ka augšžokḷa dobuma paaugstināšanas operācija ir veikta $38(48,7 \%)$ gadījumos labajā pusē, bet 40 (51,3\%) gadījumos kreisā pusē. Netika atrasta statistiski nozīmīga dzimumu atšķkirība $(p>0,05)$ (6.3. attēls).

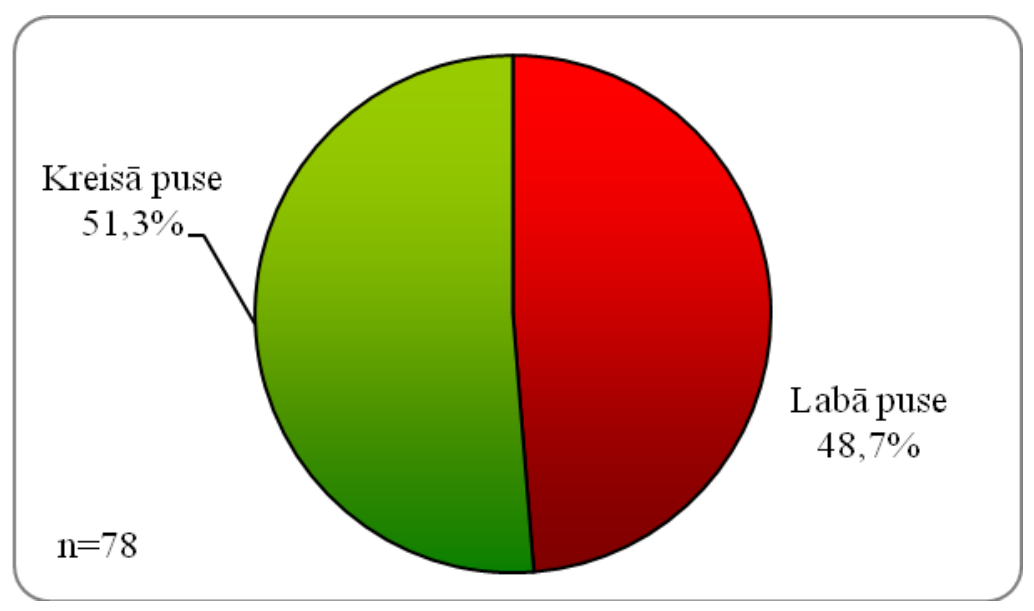

\section{3. att. Operācijas puses}


Veicot operācijas reǵistrāciju žurnālu analīzi tika reǵistrēti arī augšžokḷa dobuma pamatnes paaugstināšanas operācijas laikā pielietotie kaulu aizvietojošie biomateriāli. Deviņos gadījumos (11,5\%) tika lietots Tutogen, Tutogen Medical GmbH, Vācija. Septiņos gadījumos (9\%) tika lietots Straumann BoneCeramic, Institute Straumann $A G$, Šveice. Divos gadījumos (2,6\%) tika lietotas RTU hidroksiapatīta granulas, LR patents Nr. P-10-30, Latvija. Piecpadsmit gadījumos (19,2\%) tika lietots 4Bone SBS, Biomatlane, Francija, bet 45 (57,7\%) gadījumos operācija bija veikta lietojot Bio-Oss, Geistlich Biomaterials, Šveice (6.4. attēls).

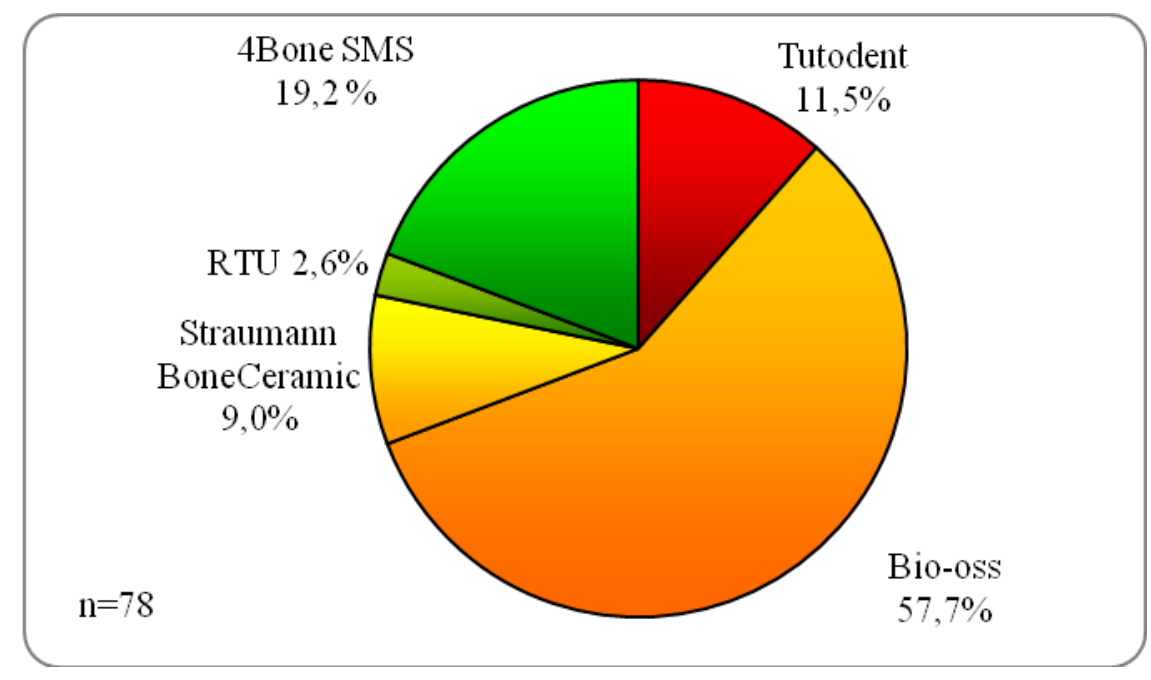

\section{4. att. Lietoto transplantātu biomateriālu sadalījums}

Lietotos kaulu aizstājošos biomateriālus, kas iekļauti šajā pētījumā, var sadalīt trīs grupās: allogēnie (Tutogen), ksenogēnie (Bio-Oss), sintētiskie materiāli (RTU hidroksiapatīts; Straumann BoneCeramic; 4Bone SBS). Grupējot gadījumos, no šāda sadalījuma izriet, ka ar allogēniem materiāliem tika veiktas $9(11,5 \%)$ augšžokļu dobumu pamatnes paaugstināšanas operācijas, ar ksenogēniem - $45(57,7 \%)$ un ar sintētiskiem materiāliem - 24 (30,8\%) operācijas (6.5. attēls). Biomateriālu lietojuma sadalījumam pēc dzimuma netika konstatētas statistiski nozīmīgas atšķirības $(p>0,05)$. 


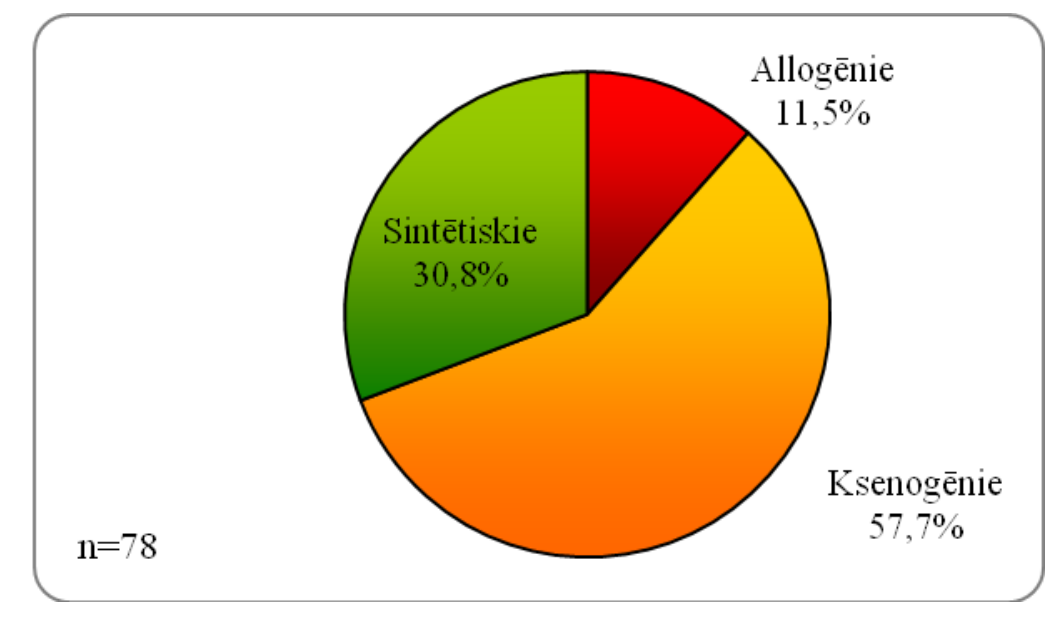

6.5. att. Biomateriālu sadalījums pa grupām

Salīdzinot savā starpā biomateriālu trīs grupas un laiku, kāds pagājis līdz atkārtotam KSDT izmeklējumam, tika konstatētas statistiski ticamas atšķirības starp ksenogēno materiālu grupu un sintētisko materiālu grupām (ANOVA, p = 0,031). Ksenogēnu grupā vidējais ilgums pēc operācijas līdz atkārtotam radiologisiskam izmeklējumam bija 1,87 SD $\pm 0,64$ gadi (mediāna 1,75), savukārt sintētiskā materiāla grupā izmeklējums vidēji tika veikts pēc 2,28 $\mathrm{SD} \pm 0,73$ gadiem (mediāna 2,13). Allogēno materiālu grupā vidēji izmeklējums tika veikts pēc 2,37 $\mathrm{SD} \pm 1,08$ gadiem (mediāna 1,67).

Kontroles grupā tika iekḷautas $20(54.1 \%)$ sievietes un $17(45,9 \%)$ vīrieši ar zobu implantātu ievietošanai paredzētiem augšžokḷa atrofiskā izauguma mugurējām daḷām (6.6. attēls).

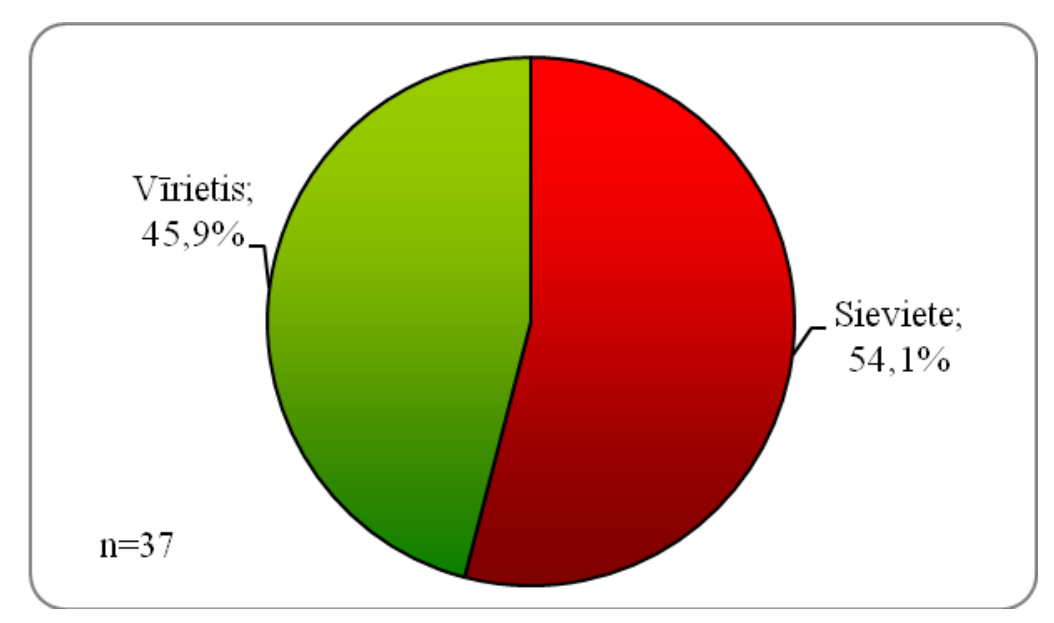

6.6. att. Kontroles grupas sadalījums pēc dzimuma 
Kontroles grupas pacientiem implantāti tika ievietoti esošā augšžokḷa reziduālajā alveolārajā kaulā. Operācijas laikā kontroles grupas vidējais vecums bija 52,81 SD \pm 9,97 gadi. Jaunākajam subjektam bija 36, bet vecākajam - 75 gadi. Sieviešu vidējais vecums operācijas laikā bija 55,40 SD $\pm 11,16$ gadi un vīriešu vidējais vecums operācijas laikā bija 49,76 SD \pm 7,58 gadi (6.7. attēls). Statistiski ticama atšķirība starp dzimumiem netika novērota (ANOVA, $\mathrm{p}=0,087$ ).

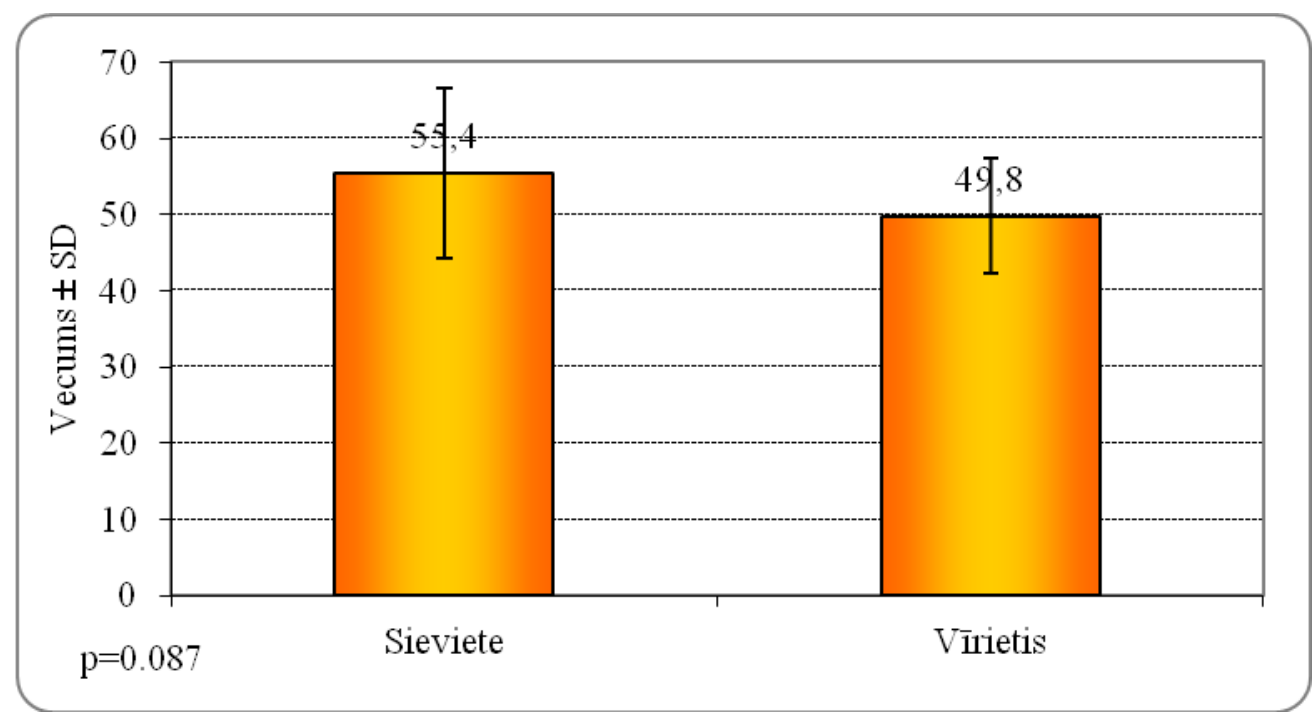

6.7. att. Kontroles grupas pacientu vecuma sadalījums pēc dzimuma

\subsection{Preoperatīvo radioloğisko izmeklējumu rezultāti}

\subsubsection{Augšžokḷa dobuma radioloǵiskās atrades}

Pirms operatīvos radioloǵiskajos izmeklējumos tika izvērtētas augšžokḷa dobuma atrades, kas varētu liecināt par esošām vai remisijā esošām iekaisuma un citām patoloǵijām. Preoperatīvajos izmeklējumos tika noteikts gḷotādas sabiezējums, sabiezētās gḷotādas tips, fiziologiskās atveres funkcionalitāte, papildu atveres esamība, vidējās deguna gliemežnīcas operācijas pusē pneimatizācija (concha bullosa).

Preoperatīvos KSDT izmeklējumos vidējais glsotādas biezums tika noteikts mm un tas neatbilda normālam sadalījumam (Kolmogorova - Smirnova tests, $\mathrm{p}=0,005$ ), un tas bija 3,95 $\mathrm{SD} \pm 4,598 \mathrm{~mm}$ (mediāna 3,00). Pirms operācijas $28(35,9 \%)$ gadījumos 
glotādas sabiezējums netika novērots vispār, $1 \mathrm{~mm}$ sabiezējums tika novērots $4(5,1 \%)$ gadījumos, 2 mm 5 (6,4\%), 3 mm 7 (9,0 \%) gadījumos un 4 mm $6(7,7 \%)$ gadījumos (6.1. tabula).

6.1. tabula

Gḷotādas sabiezējums milimetros pirms operācijas

\begin{tabular}{|c|c|c|}
\hline $\mathbf{m m}$ & Dobumu skaits & Procenti \% \\
\hline 0 & 28 & 35,9 \\
\hline 1 & 4 & 5,1 \\
\hline 2 & 5 & 6,4 \\
\hline 3 & 7 & 9,0 \\
\hline 4 & 6 & 7,7 \\
\hline 5 & 6 & 7,7 \\
\hline 6 & 5 & 6,4 \\
\hline 7 & 3 & 3,8 \\
\hline 8 & 3 & 3,8 \\
\hline 9 & 5 & 2,6 \\
\hline 12 & 1 & 6,4 \\
\hline 14 & 1 & 1,3 \\
\hline 15 & 1 & 1,3 \\
\hline 17 & 1 & 1,3 \\
\hline 20 & 1 & 1,3 \\
\hline Kopā & 78 & 100,0 \\
\hline
\end{tabular}

Gḷotādas sabiezējuma tips tika noteikts visiem augšžokḷa dobumiem (6.2. tabula). 
Gḷotādas sabiezējuma tips pirms operācijas

\begin{tabular}{|l|c|c|}
\hline Gḷotādas tips & Biežums & Procenti \\
\hline Nav sabiezēts & 28 & 35,9 \\
\hline Bazāli & 36 & 46,2 \\
\hline Cistiski & 7 & 9,0 \\
\hline Neregulāri & 3 & 3,8 \\
\hline Cirkulāri & 4 & 5,1 \\
\hline Totāli aizēnots & 0 & 0 \\
\hline Kopā & 78 & 100,0 \\
\hline
\end{tabular}

Augšžokḷa dobuma fiziologiiskās atveres funkcionalitāte tika noteikta kā atveres obstrukcija vai funkcionāla atvere (norma). No 78 dobumiem 69 (88,5\%) gadījumos preoperatīvajos KSDT izmeklējumos tika konstatēta brīva, funkcionējoša atvere. Statistiski biežāk fizioloğiskās atveres obstrukcija bija vērojama cirkulāra gḷotādas sabiezējuma tipa $\left(\mathrm{Chi}^{2}\right.$ tests, $\left.\mathrm{p}=0,001\right)$, kaut arī attēlā redzams, ka atveres obstrukcija ir novērojama arī normālas un bazāli sabiezētas gḷotādas gadījumā (6.8. attēls).

Papildus atvere dobumos parasti ir redzama dorsāli no fiziologiskās atveres augšžokḷa dobuma mediālā sienā. Kopumā preoperatīvajos izmeklējumos papildus atvere tika atrasta $17(21,8 \%)$ dobumos.

Vidējās deguna gliemežnīcas operācijas pusē pneimatizācija - concha bulloa,tika reg̣istrēta pirms operācijas KSDT izmeklējumos. Tā netika konstatēta 44 (56,4\%) deguna ejās. 


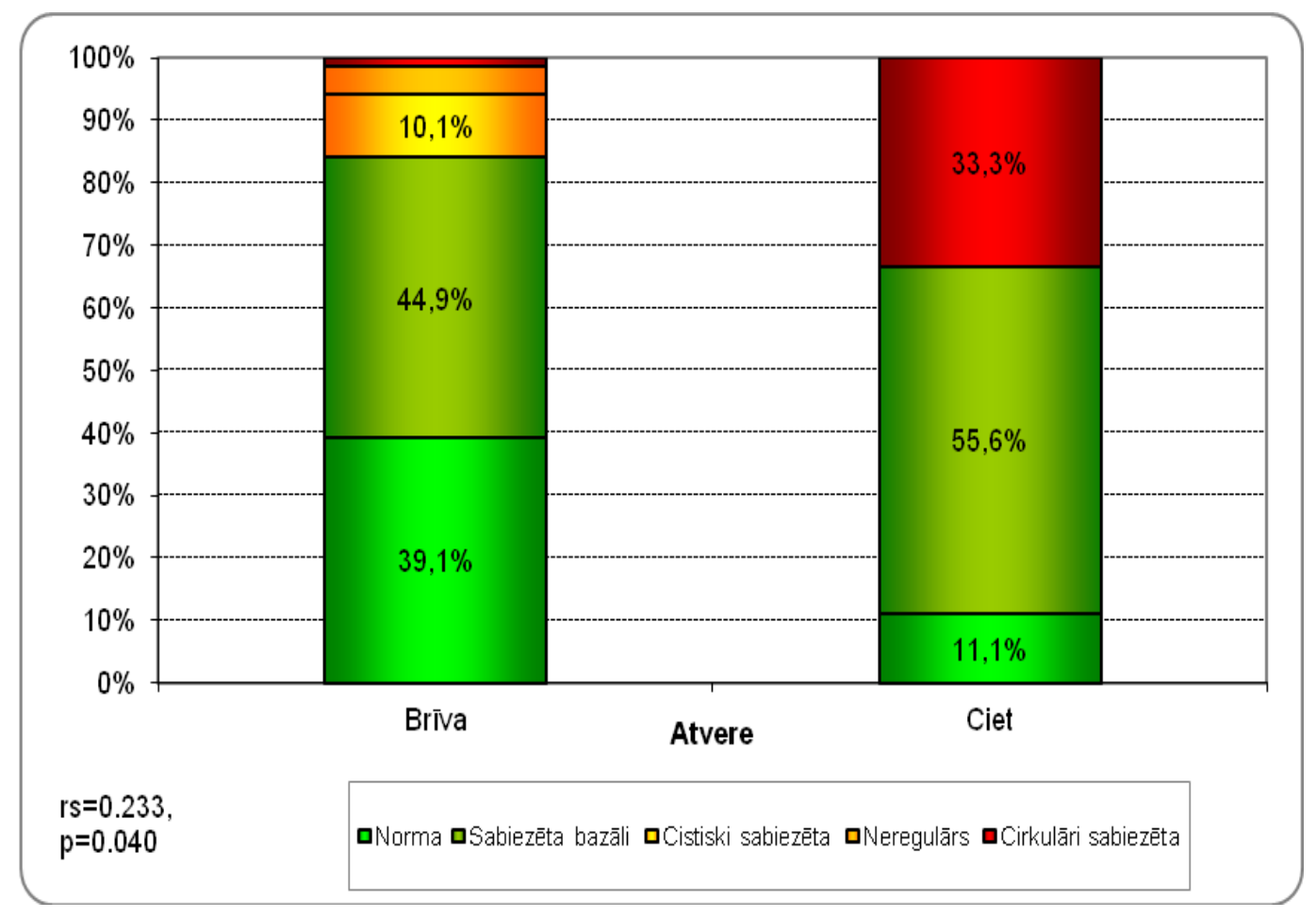

6.8. att. Fiziologisko atveru funkcionalitāte un gḷotādas sabiezējuma tips pirms operācijas

\subsubsection{Alveolārā izauguma kaula mērījumu rezultāti}

Pētījuma gaitā tika noteikts kaula augstums, platums un attēla nomelnējuma līmeņa vērtība atrofiskā alveolārā izauguma kaula operācijas vietā. Pielietojot Kolmogorova - Smirnova testu, tika noteikta šo trīs parametru atbilstība normālam sadalījumam. Rezultātā tika konstatēts, ka kaula augstums normālam sadalījumam neatbilst $(\mathrm{p}=0,664)$, bet platums $(\mathrm{p}=0,331)$ un kaula nomelnējuma vērtība attēlā $(\mathrm{p}=0,009)$ - atbilst. Kaula vidējais augstums bija 3,77 $\mathrm{SD} \pm 2,227 \mathrm{~mm}$, kaula vidējais platums bija 7,13 SD $\pm 2,276$ mm (mediāna 7,00), kaula nomelnējuma līmenis 141,08 $\mathrm{SD} \pm 154,280 \mathrm{VV}$ (mediāna 111,5). Salīdzinot šos parametrus starp dzimumiem statistiski nozīmīga atšķirība netika konstatēta (6.3. tabula). 
6.3. tabula

Kaula augstuma, platuma un nomelnējuma līmeņa vērtības sadalījums pēc pacientu dzimuma preoperatīvos izmeklējumos

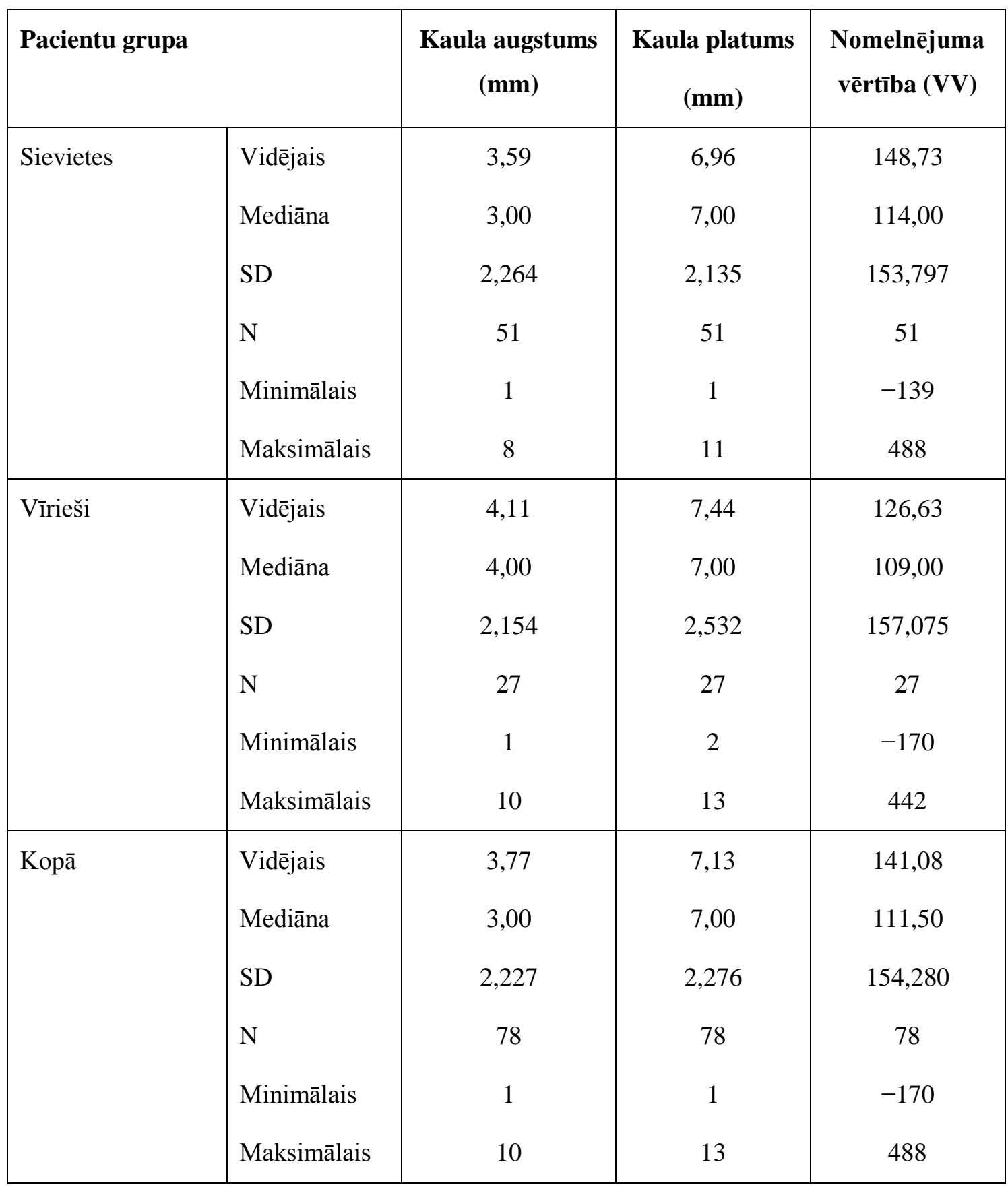

Kaula platuma, augstuma un nomelnējuma līmeņa mērījumi pirms augšžokḷa dobuma pamatnes paaugstināšanas operācijas tika pakḷauti statistiskai korelācijas analīzei. Tika konstatēta statistiski ticama pozitīva korelācija starp kaula augstumu un kaula platumu pirms operācijas $(r=0,315, p=0,005)$ un statistiski ticama negatīva korelācija starp kaula augstumu un kaula nomelnējuma līmeņa vērtību pirms operācijas 
$(\mathrm{r}=-0,285, \mathrm{p}=0,012)$. Korelācijas analīzē ar kaula augstumu tika pielietota neparametriskā Spīrmena korelācijas analīze, jo kaula augstuma mērījumi neatbilda normālam datu sadalījumam. Analizējot šos parametrus pēc dzimuma, vīriešiem netika konstatētas statistiski nozīmīgas korelācijas. Sievietēm tika konstatēta negatīva korelācija starp kaula augstumu un nomelnējuma līmeni pirms operācijas izmeklējumos (Spīrmena korelācija, $r=-0,422, p=0,002$ ).

Salīdzinot datus pēc biomateriāla, ko lietoja augšžokḷa dobuma pamatnes paaugstināšanas operācijas laikā, un preoperatīvos kaula parametrus, arī netika konstatētas statistiski nozīmīgas atšķirības $(\mathrm{p}>0,05)$. Arī pēc biomateriāla sadalījuma trīs izcelsmes grupās netika konstatētas statistiski nozīmīgas atšksirības ( $p$ > 0,05).

Tā kā kontroles grupa tika veidota, lai salīdzinātu kaula nomelnējuma līmeni attēlā un metāla artefaktu ietekmi uz attēla radioloǵiskā nomelnējuma līmeņa izmaiṇām, tad implantāta ievietošanas vietā tika mērīts kaula nomelnējuma līmenis implantācijas vietā. Kontroles grupas augšžokḷa alveolārā kaula vidējais nomelnējuma līmenis pirms implantāta ievietošanas bija 165,16 SD $\pm 139,611$ VV. Sieviešu dzimuma pārstāvēm tas bija 183,50 SD \pm 93,511 VV, vīriešu 143,59 SD \pm 180,434 VV (6.4. tabula).

6.4. tabula

Kaula attēla nomelnējuma līmeņa vērtības sadalījums pēc dzimuma kontroles grupai preoperatīvos izmeklējumos

\begin{tabular}{|l|l|c|}
\hline \multicolumn{2}{|l|}{ Pacientu grupa } & $\begin{array}{c}\text { Nomelnējuma } \\
\text { vērtība (VV) }\end{array}$ \\
\hline Sievietes & Vidējais & 183,00 \\
& Mediāna & 163,00 \\
& SD & 93,511 \\
& N & 20 \\
& Minimālais & 35 \\
& Maksimālais & 320 \\
\hline
\end{tabular}

6.4. tabulas turpinājums nākamajā lapā 
6.4. tabulas turpinājums.

\begin{tabular}{|l|l|c|}
\hline \multicolumn{2}{|l|}{ Pacientu grupa } & $\begin{array}{c}\text { Nomelnējuma } \\
\text { vērtība (VV) }\end{array}$ \\
\hline Vīrieši & Vidējais & 143,59 \\
& Mediāna & 132,00 \\
& SD & 180,434 \\
& N & 17 \\
& Minimālais & -116 \\
& Maksimālais & 699 \\
\hline Kopā & Vidējais & 165,16 \\
& Mediāna & 145,00 \\
& SD & 139,611 \\
& N & 37 \\
& Minimālais & -116 \\
& Maksimālais & 699 \\
\hline
\end{tabular}

\section{3. Postoperatīvo radioloğisko izmeklējumu rezultāti}

\subsubsection{Augšžokḷa dobuma radioloğiskās atrades}

Postoperatīvajos KSDT izmeklējumos vidējais gḷotādas biezums tika noteikts milimetros un tas neatbilda normālam sadalījumam (Kolmogorova - Smirnova tests, $\mathrm{p}=0,005)$. Tas bija 3,95 SD $\pm 4,637 \mathrm{~mm}$ (mediāna 2,50). Divdesmit divos $(28,2 \%)$ dobumos gḷotādas sabiezējums netika konstatēts vispār. Sabiezējums līdz $1 \mathrm{~mm}$ tika konstatēts 4 (5,1\%) gadījumos, 2 mm 13 (16,7\%) gadījumos, 3 mm 7 (9,0\%) gadījumos un $4 \mathrm{~mm}(5,1 \%)$ gadījumos (6.5. tabula). 
6.5. tabula

Augšžokḷa dobuma glotādas sabiezējums milimetros pirms operācijas

\begin{tabular}{|c|c|c|}
\hline $\mathbf{m m}$ & Dobumu skaits & Procenti \% \\
\hline 0 & 22 & 28,2 \\
\hline 1 & 4 & 5,1 \\
\hline 2 & 13 & 16,7 \\
\hline 3 & 7 & 9,0 \\
\hline 4 & 4 & 5,1 \\
\hline 5 & 7 & 9,0 \\
\hline 6 & 3 & 3,8 \\
\hline 7 & 6 & 7,7 \\
\hline 8 & 3 & 3,8 \\
\hline 9 & 2 & 2,6 \\
\hline 10 & 2 & 2,6 \\
\hline 12 & 1 & 1,3 \\
\hline 13 & 2 & 2,6 \\
\hline 20 & 1 & 1,3 \\
\hline $\begin{array}{l}\text { Totāli } \\
\text { aizēnots }\end{array}$ & 1 & 1,3 \\
\hline Kopā & 78 & 100,0 \\
\hline
\end{tabular}

Salīdzinot ar izmeklējuma rezultātiem pirms operācijas, tika iegūta statistiski nenozīmīga atšksirība (Vilkoksona tests, $\mathrm{p}=0,642$ ). Tāpat netika konstatētas statistiski nozīmīgas atškirības gḷotādas sabiezējumā atkarībā no kaulu aizvietojošā materiāla grupas, kas lietots operācijas laikā (Kruskola - Valisa H - tests, $\mathrm{p}=0,197$ ).

Gḷotādas sabiezējuma tips tika noteikts visiem augšžokḷa dobumiem, kam tika veikta pamatnes paaugstināšanas operācija (6.6. tabula). Netika konstatēta statistiski ticama atšksirība starp rezultātiem pirms un pēc operācijas (Vilkoksona tests, $p=0,215$ ). 
Augšžokḷa dobuma gḷotādas sabiezējuma tips pēc operācijas

\begin{tabular}{|l|c|c|}
\hline Gḷotādas tips & Biežums & Procenti \\
\hline Nav sabiezēts & 22 & 28,2 \\
\hline Bazāli & 40 & 51,3 \\
\hline Cistiski & 5 & 6,4 \\
\hline Neregulāri & 3 & 3,8 \\
\hline Cirkulāri & 7 & 9,0 \\
\hline Totāli aizēnots & 1 & 1,3 \\
\hline Kopā & 78 & 100,0 \\
\hline
\end{tabular}

Pēc operācijas izmeklējumos ievērojami samazinājās fiziologiisko atveru obstrukcija normālas gḷotādas gadījumā, bet tā pieauga cirkulāri sabiezētas un totāli aizēnota dobuma gadījumā $\left(\mathrm{Chi}^{2}\right.$ tests, $\left.\mathrm{p}=0,001\right)$ (6.9. attēls).

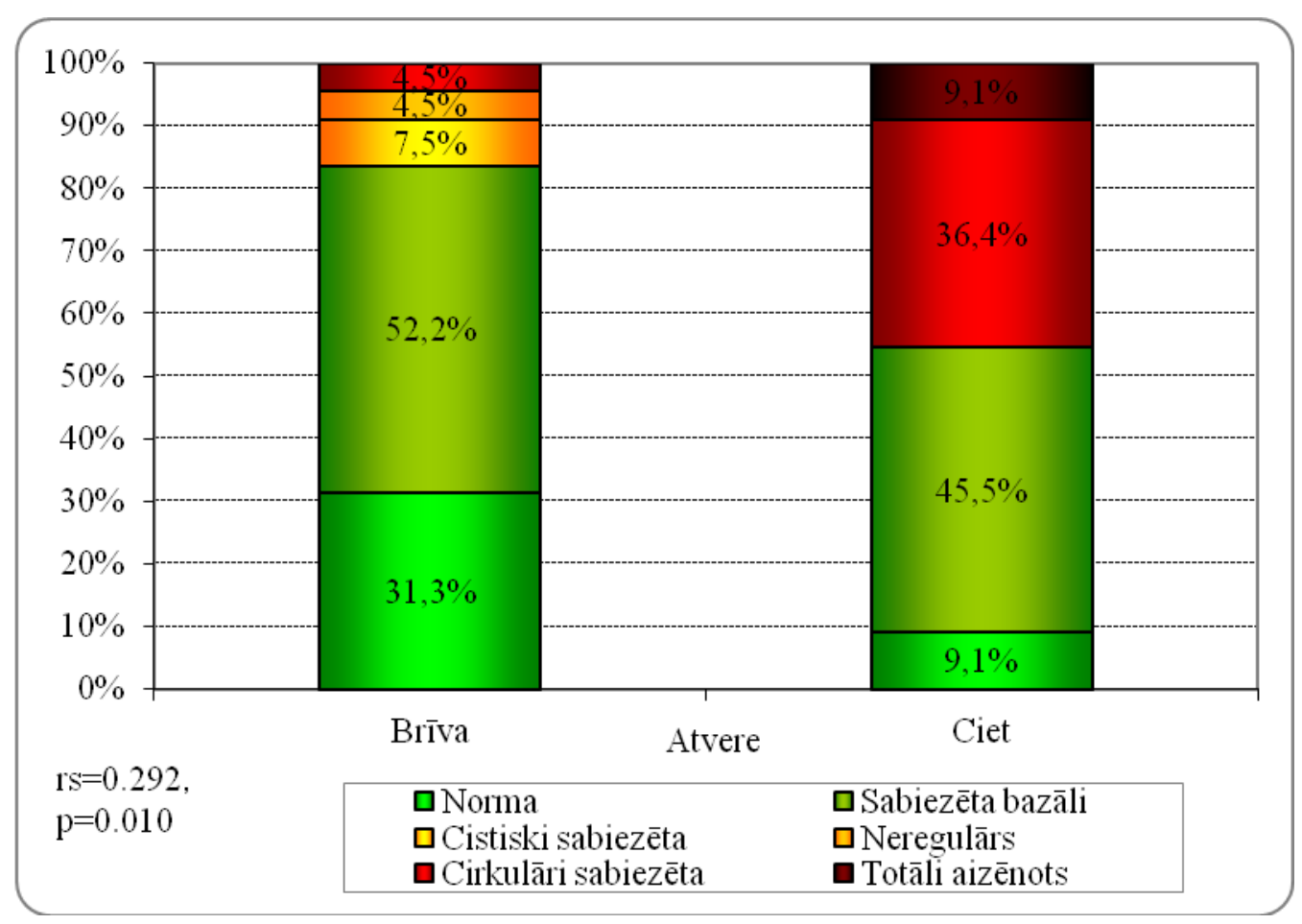

6.9. att. Fiziologisko atveru funkcionalitāte un gḷotādas sabiezējuma tips pēc operācijas 
Netika konstatētas statistiski nozīmīgas atšķirības gl̦otādas sabiezējumā atkarībā no kaulu aizvietojošā materiāla grupas, kas lietots operācijas laikā (P̄̄rsona Chi ${ }^{2}$, $\mathrm{p}=0,210)$.

Pēc operācijas $67(85,9 \%)$ gadījumos tika konstatēta pneimatizēta, brīva fiziolog̣iskā augšžokḷa dobuma atvere. Salīdzinot rezultātus ar pirms operācijas rezultātiem netika atrasta statistiski ticama atšķirība (Vilkoksona tests, $p=0,527$ ). Tāpat netika konstatētas statistiski ticamas atšķirības salīdzinot šos datus ar operācijas laikā pielietoto kaulu aizvietojošo materiālu grupām (Pīrsona $\mathrm{Chi}^{2}, \mathrm{p}=0,180$ ). Toties korelējot atveres stāvokli ar gḷotādas sabiezējumu, tika konstatēta pozitīva korelācija (Spīrmena korelācija $r=0,256, p=0,024)(6.10$. attēls).

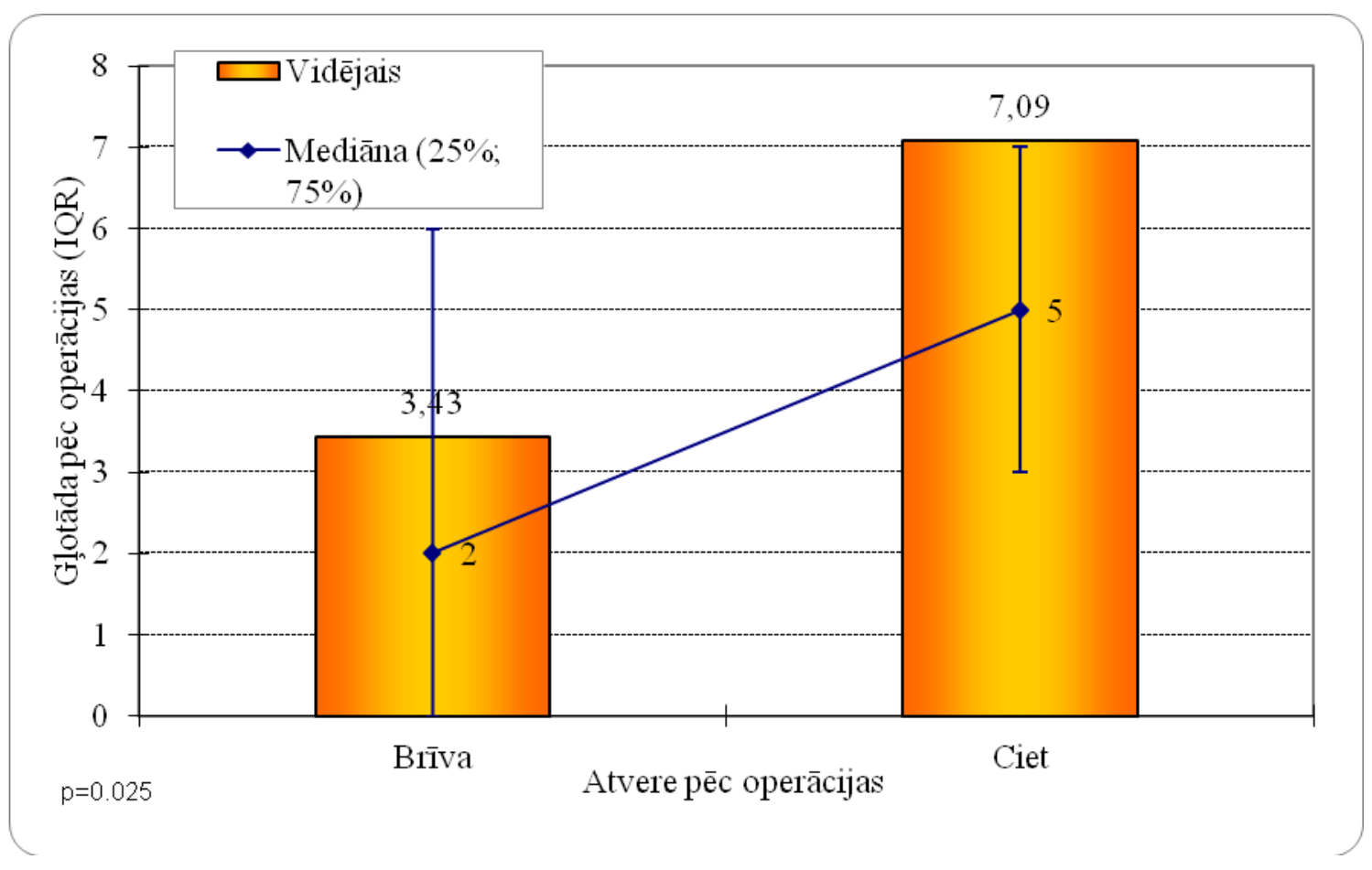

\subsection{0. att. Korelācija starp gḷotādas sabiezējumu un fizioloğiskās atveres funkcionalitāti pēc operācijas izmeklējumos}

Pēc operācijas izmeklējumos tika atzīmētas tieši tik pat daudz - $17(21,8 \%)$ papildus atveru kā pirms operācijas.

Pēc operācijas tika reǵistrēta concha bullosa operācijas pusē. Trīsdesmit astoṇos (48,7\%) gadījumos tika atklāta pneimatizēta deguna vidējā gliemežnīca. Salīdzinot ar preoperatīviem izmeklējumiem, pneimatizēto gliemežnīcu daudzums ir pieaudzis un Vilkoksona tests uzrāda statistiski ticamu atšķirību starp šādu atradi pirms un pēc 
augšžokḷa dobuma pamatnes paaugstināšanas operācijas $(p=0,025)$. Spīrmena korelācija starp pēc operācijas concha bullosa un gḷotādas sabiezējumu uzrādīja negatīvu vāju korelāciju starp abiem mērījumiem $(r=-0,271, p=0,017)$ (6.11. attēls).

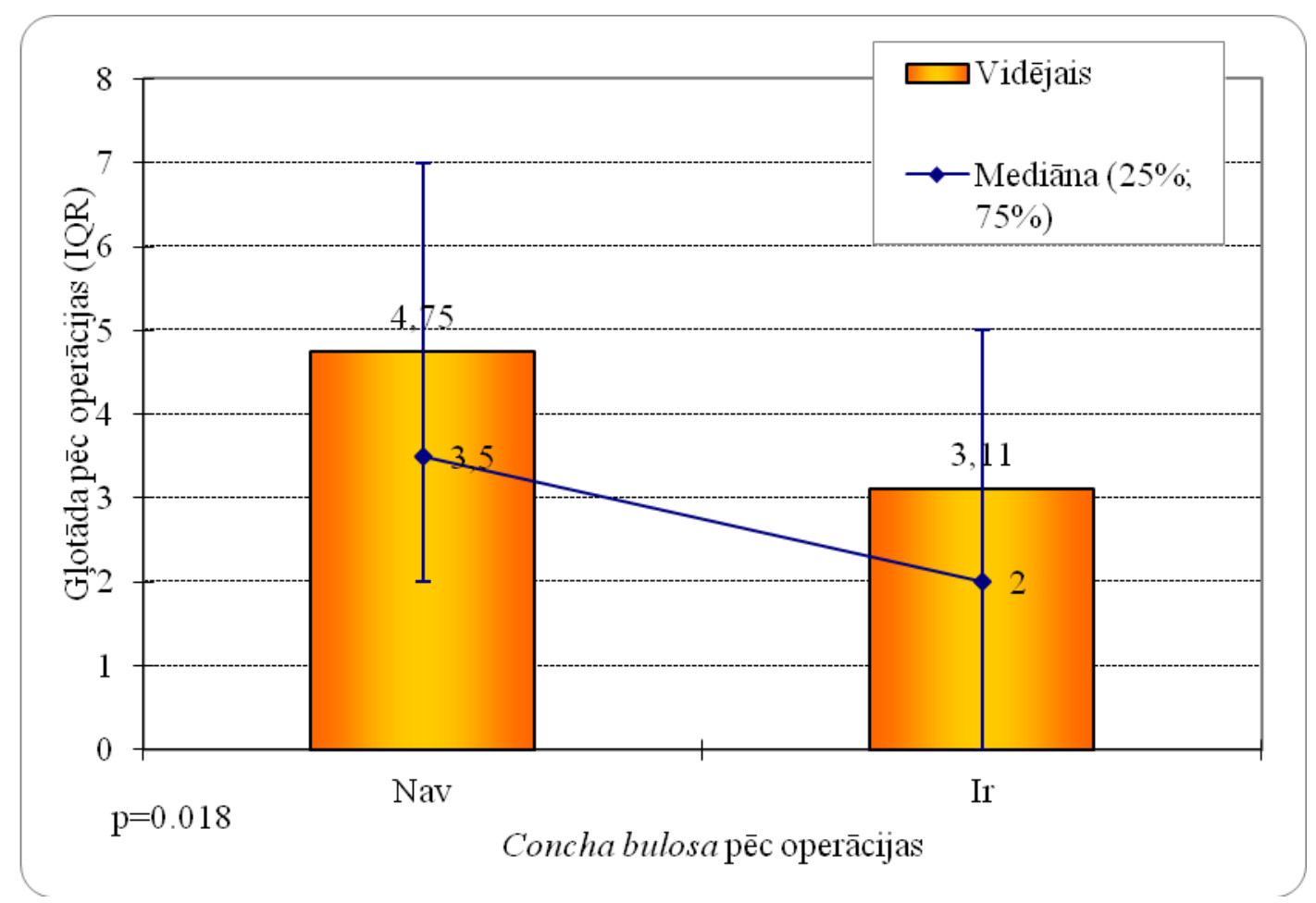

\subsection{1. att. Korelācija starp gḷotādas sabiezējumu un concha bullosa pēc operācijas izmeklējumos}

Augšžokḷa dobuma tilpums tika mērīts kubikmilimetros $\left(\mathrm{mm}^{3}\right)$. Pirms operācijas augšžokḷa dobuma tilpums vidēji bija 19030,23 SD $\pm 6664,577 \mathrm{~mm}^{3}$, bet pēc operācijas vidēji tas bija 16643,12 $\mathrm{SD} \pm 5705,934 \mathrm{~mm}^{3}$. Abos gadījumos mainīgie atbilda normālam sadalījumam. Salīdzinot main̄̄gos ar pāra $\mathrm{t}$ - testu, tika iegūta statistiski ticama atšķirība starp dobuma tilpumu pirms un pēc operācijas ( $\mathrm{p}<0,001)$ (6.12. attēls). 


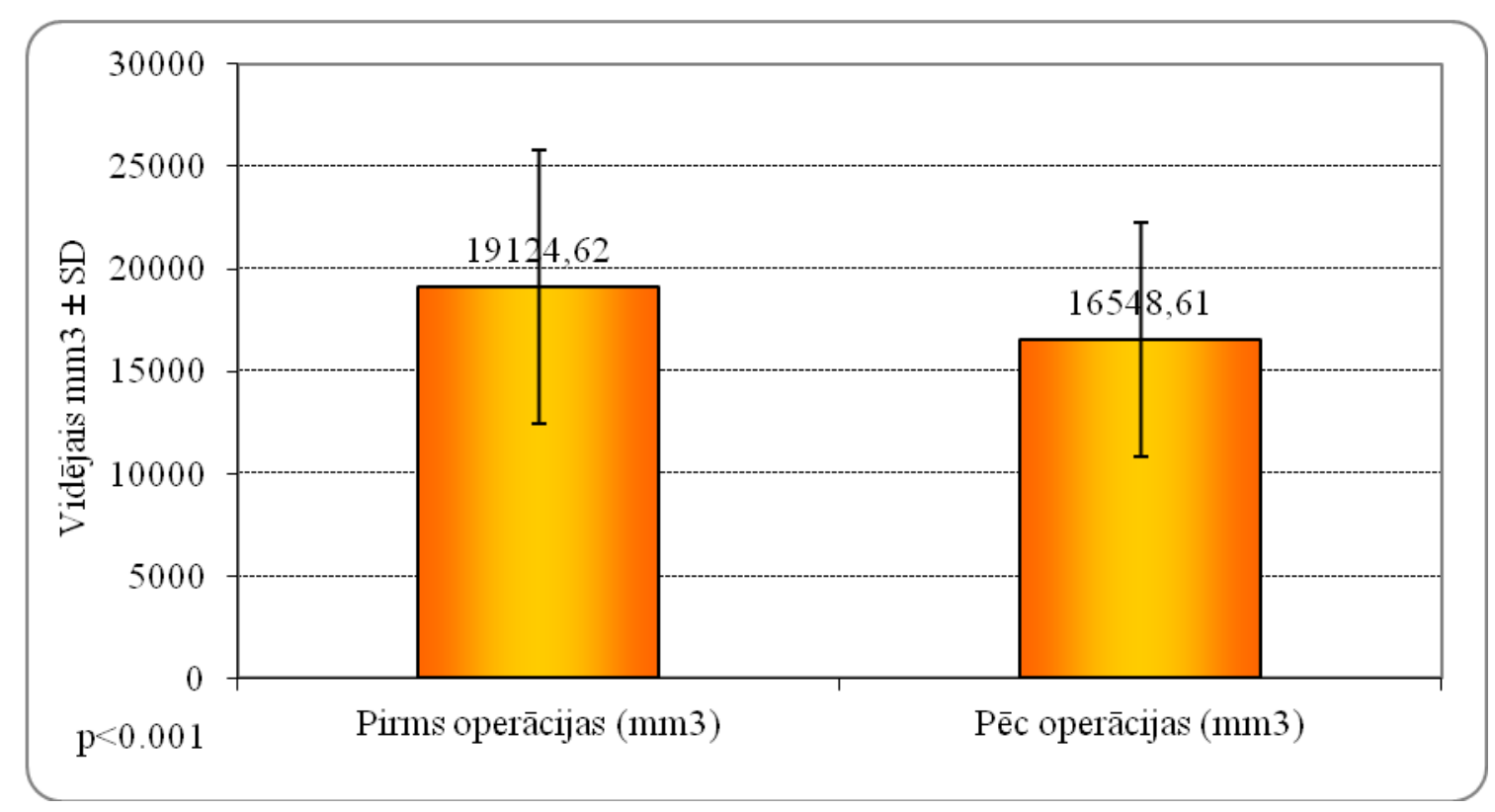

6.12. att. Auǧ̌̌̌okḷa dobuma tilpums pirms un pēc ADPP operācijas

\subsubsection{Alveolārā kaula un augmentētās zonas mērījumi}

Pēc operācijas KSDT izmeklējumos tika mērīts augmentētās zonas augstums, platums un garums (mm). Vidējais augstums pēc operācijas izmeklējumos bija 15,92 $\mathrm{SD} \pm 2,900 \mathrm{~mm}$ (minimālais 10, maksimālais 22). Vidējais augmentētās zonas platums bija 12,91 $\mathrm{SD} \pm 2,569 \mathrm{~mm}$ (minimālais 8 , maksimālais 19). Vidējais augmentētās zonas garums bija 18,79 $\mathrm{SD} \pm 5,097 \mathrm{~mm}$ (minimālais 5, maksimālais 33). Visi trīs mērījumi atbilda normālam sadalījumam (Kolmogorova - Smirnova tests, p > 0,05). Salīdzinot augmentētās zonas izmērus starp dzimumiem, statistiski ticamas atšķirīibas netika konstatētas (ANOVA, $\mathrm{p}>0,005$ ).

Korelējot pirms operācijas kaula lineāros mērījumus ar augmentētās zonas lineārajiem mērījumiem tika iegūta korelācija starp augmentētās zonas platumu un garumu (P̄̄rsona korelācija, $\mathrm{r}=0,396, \mathrm{p}<0,0001$ ) un augmentētās zonas platumu un augstumu (Pīrsona korelācija, $\mathrm{r}=0,332, \mathrm{p}=0,003$ ). Korelējot ar neparametrisko Spīrmena testu kaula augstumu un augmentētās zonas parametrus tika iegūta statistiski ticama negatīva korelācija starp kaula augstumu un augmentētās zonas platumu $(\mathrm{r}=-0,282, \mathrm{p}=0,012)$ un negatīva korelācija starp preoperatīvo kaula augstumu un augmentētās zonas garumu $(r=-0,415, \mathrm{p}<0,0001)$. Arī vīriešu dzimuma pārstāvjiem 
tika konstatēta negatīva korelācija starp preoperatīvo kaula augstumu un augmentētās zonas platumu (Spīrmena korelācija, $r=-0,380, p=0,051$ ) un kaula augstumu un augmentētās zonas garumu (Spīrmena korelācija, $r=-0,603, p=0,001$ ). Sievietēm nekādas korelācijas starp pirms operācijas lineārajiem mērījumiem un pēc operācijas augmentācijas zonas lineāro parametru mērījumiem netika konstatētas.

Salīdzinot augmentētās zonas izmērus pēc lietoto biomaterialu grupām tika konstatētas statistiski ticamas atšķirības starp tiem, ko apstiprināja gan parametriskie, gan neparametriskie testi (ANOVA, p < 0,05; Kruskala - Valisa tests, $\mathrm{p}<0,05)(6.7$. tabula).

6.7. tabula

Biomateriālu grupu augmentētās zonas parametri

\begin{tabular}{|l|l|c|c|c|}
\hline Parametri & Biomateriāli & N & Vidējais (mm) & SD \\
\hline \multirow{4}{*}{ Augstums } & Allogēnie & 9 & 14,67 & 2,828 \\
\cline { 2 - 5 } & Ksenogēnie & 45 & 17,04 & 2,730 \\
\cline { 2 - 5 } & Sintētiskie & 24 & 14,29 & 2,293 \\
\cline { 2 - 5 } & Kopā & 78 & 15,92 & 2,900 \\
\hline \multirow{4}{*}{ Platums } & Allogēnie & 9 & 10,89 & 2,667 \\
\cline { 2 - 5 } & Ksenogēnie & 45 & 13,73 & 2,562 \\
\cline { 2 - 5 } & Sintētiskie & 24 & 12,13 & 1,872 \\
\cline { 2 - 5 } & Kopā & 78 & 12,91 & 2,569 \\
\hline \multirow{5}{*}{ Garums } & Allogēnie & 9 & 18,33 & 5,099 \\
\cline { 2 - 5 } & Ksenogēnie & 45 & 20,44 & 4,993 \\
\cline { 2 - 5 } & Sintētiskie & 24 & 15,88 & 3,993 \\
\cline { 2 - 5 } & Kopā & 78 & 18,79 & 5,097 \\
\hline
\end{tabular}

Tika veikta Fišera LSD (Least Significant Difference test, angḷu val) analīze, lai noteiktu starp kurām biomateriālu grupām un pēc kuriem augmentētās zonas parametriem ir vērojama statistiski ticama atšķirība. Augmentētās zonas augstums statistiski ticami atšķ̄īās ksenogēno un allogēno biomateriālu starpā $(p=0,015)$, 
ksenogēno un sintētisko materiālu starpā ( $\mathrm{p}<0,0001)$. Augmentētās zonas platums statistiski ticami atšķīrās ksenogēno un allogēno materiālu starpā ( $\mathrm{p}=0,002)$, kā arī ksenogēno un sintētisko materiālu starpā $(\mathrm{p}=0,009)$. Augmentêtās zonas garums statistiski ticami atšķīrās starp ksenogēniem un sintētiskiem materiāliem ( $\mathrm{p}<0,0001)$.

Attēla nomelnējuma līmenis tika noteikts piecos punktos ap implantātu, kas ievietots ar kaulu aizvietojošiem biomateriāliem pastiprinātā augšžokḷa dobuma pamatnē. Mērījuma vietas tika nosauktas šādi: bukāli kaulā (BK), bukāli augmentētajā zonā (BAZ), apikāli (AP), palatināli augmentētajā zonā (PAZ), palatināli kaulā (PK). Attēla nomelnējuma līmenis tika reǵistrēts nomelnējuma līmeņa vērtības vienībās (VV). Tā kā 65 gadījumos implantāts tika ievietots reizē ar augšžokḷa dobuma pamatnes paaugstināšanu, tad šāds piecu punktu mērījums ap implantātu tika veikts šiem gadījumiem. Apikālajā apvidū atsevišşos gadījumos mērījumu nav iespējams veikt, jo materiāla daudzums ir ārkārtīgi mazs vai arī implantāta apikālā daḷa nav vispār ar to nav pārklāta. Tādēḷ salīdzinājumā ar citiem mērījuma punktiem apikālā (AP) mērījumā iztrūkst 3 mērījumi. Pielietojot Kolmogorova - Smirnova testu tika konstatēts, ka visi mērījumi visos piecos punktos atbilst normālam sadalījumam ( $p>0,05)$. Rezultāti apkopoti 6.8. tabulā un 6.13. attēlā.

6.8. tabula

Implantācijas zona radioloğiskā nomelnējuma līmeņa mērījumu vidējie lielumi

\begin{tabular}{|l|c|c|c|c|c|}
\hline & BK & BAZ & AP & PAZ & PK \\
\hline N & 65 & 65 & 62 & 65 & 65 \\
\hline Vidējais & 1135,34 & 998,09 & 726,73 & 862,77 & 986,71 \\
\hline SD & 305,552 & 326,474 & 298,614 & 359,374 & 343,79 \\
\hline Minimālais & 536 & 59 & 210 & 248 & 298 \\
\hline Maksimālais & 1908 & 1639 & 1590 & 1831 & 1983 \\
\hline
\end{tabular}




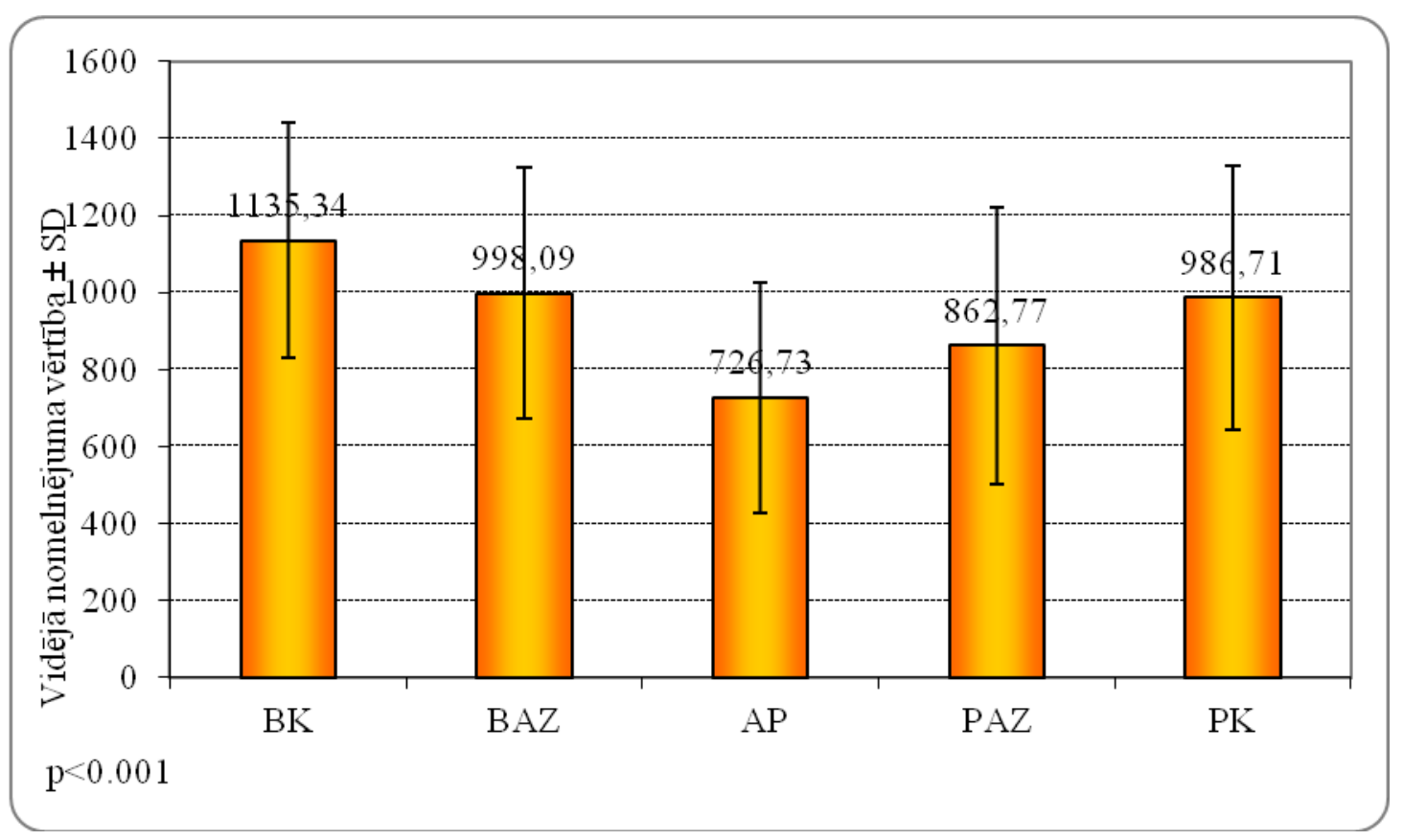

6.13. att. Nomelnējuma līmeņa vērtības mērījuma vidējo lielumu grafiskais attēlojums

Piecu punktu mērījumiem tika veikta korelācijas analīze, lai noteiktu vai pastāv saistība starp mērījumiem. Parametriskā korelācijas analīzē tika atrastas korelācijas starp sekojošiem mērījumu pāriem: BAZ - BK, AP - BAZ, PK -PAZ. Visstiprākā korelācija tika konstatēta starp PAZ - AP mērījumiem. Konstatētās korelācijas ir parādītas 6.9. tabulā.

6.9. tabula

Piecu nomelnējuma līmeņa vērtību mērījumu savstarpējā korelācija

\begin{tabular}{|l|l|c|c|c|c|c|}
\hline \multicolumn{2}{|l|}{} & BK & BAZ & AP & PAZ & PK \\
\hline BK & Pīrsona korel. & 1 & & & & \\
& P & & & & & \\
N & 65 & & & & \\
\hline
\end{tabular}

6.9.tabulas turpinājums nākamajā lapā. 
6.9. tabulas turpinājums.

\begin{tabular}{|l|l|c|c|c|c|c|}
\hline & & BK & BAZ & AP & PAZ & PK \\
\hline BAZ & Pīrsona korel. & 0,296 & 1 & & & \\
& P & 0,017 & & & & \\
\hline AP & Pīrsona korel. & 0,231 & 0,362 & 1 & & \\
& P & 0,071 & 0,004 & & & \\
& N & 62 & 62 & 62 & & \\
\hline PAZ & Pīrsona korel. & 0,014 & 0,196 & 0,405 & 1 & \\
& P & 0,914 & 0,117 & 0,001 & & \\
& N & 65 & 65 & 62 & 65 & \\
\hline PK & Pīrsona korel. & 0,148 & 0,072 & 0,280 & 0,346 & 65 \\
& P & 0,240 & 0,570 & 0,027 & 0,005 & \\
& N & 65 & 65 & 62 & 65 & 65 \\
\hline
\end{tabular}

Salīizinot piecus nomelnējuma līmeņa vērtības mērījumus savā starpā pēc MANOVA testa tika atrasta statistiski ticamas atšķirības starp visiem pieciem mērījuma punktiem ( $\mathrm{p}<0,0001)$. Savukārt salīdzinot savā starpā dažādus piecu punktu mērījumu pārus, statistiski ticama atšķirība netika atrasta tikai pārim PK - BAZ (p =0,846). Tātad visiem pāriem, izņemot $\mathrm{PK}$ - BAZ, ir atšķirīgi mērījumu dati.

Analizējot piecu punktu nomelnējuma līmeņa mērījumu datus pēc dzimumu sadalījuma netika atrasta neviena statistiski nozīmīga atšksirība.

Pieci nomelnējuma līmeņa mērījumi tika salīdzināti arī ņemot vērā trīs biomateriālu sadalījumu grupas: allogēnie, ksenogēnie, sintētiskie materiāli. ANOVA tests uzrādīja statistiski nozīmīgas atšķirības starp biomateriālu nomelnējuma līmeņa vērtībām BK (p = 0,013) (6.14. attēls), BAZ (p = 0,004) (6.15. attēls), AP (p < 0,0001) (6.16. attēls) un PAZ (p=0,042) (6.17. attēls) mērījumu vietās, bet nav vērojama atšksirība punktā PK ( $\mathrm{p}=0,581)$ (6.18. attēls). Zemāk ANOVA testa rezultātu grafiski attēlojumi. 


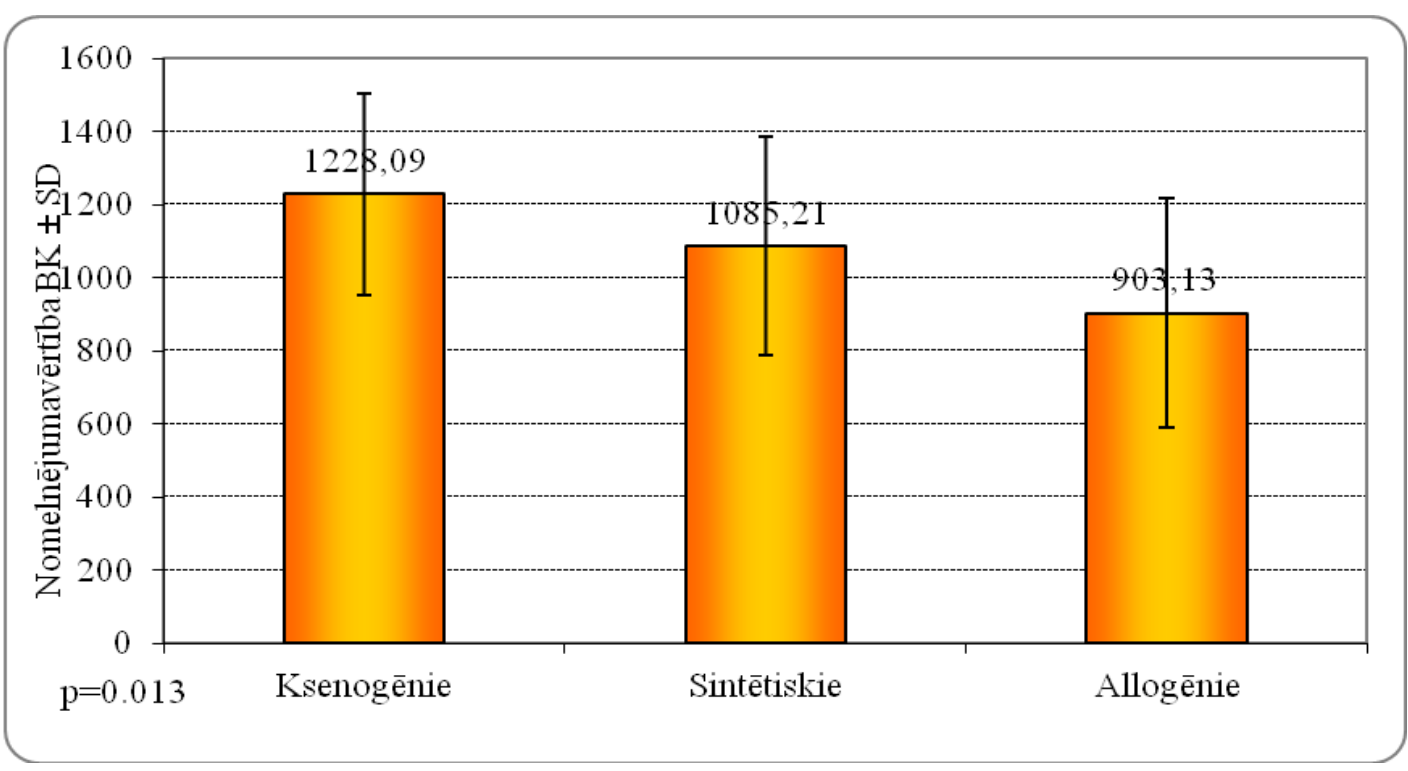

6.14. att. Attēla vidējā nomelnējuma līmeṇa salīdzinājums mērījuma punktā BK

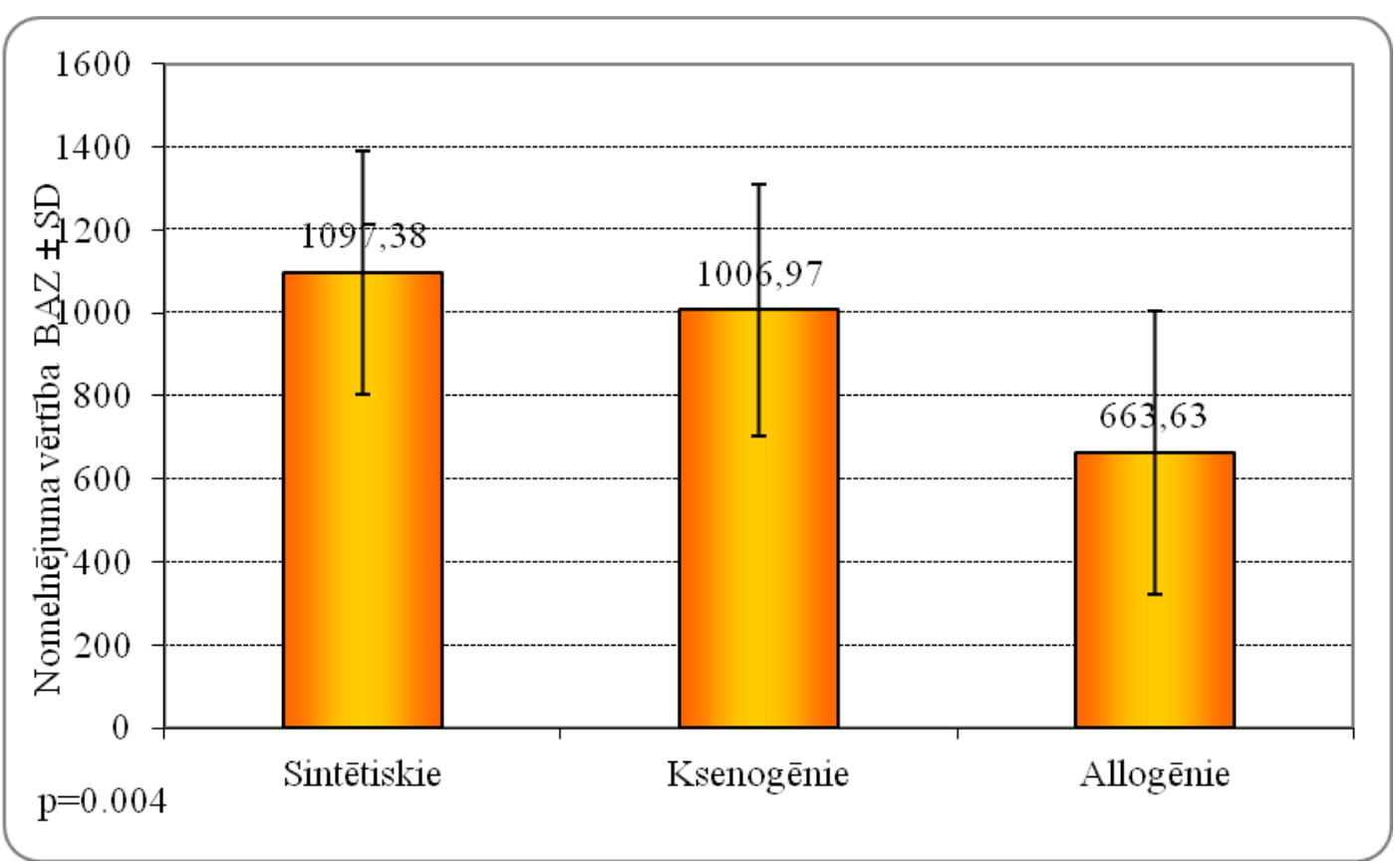

6.15. att. Attēla vidējā nomelnējuma līmeṇa salīdzinājums mērījuma punktā BAZ 


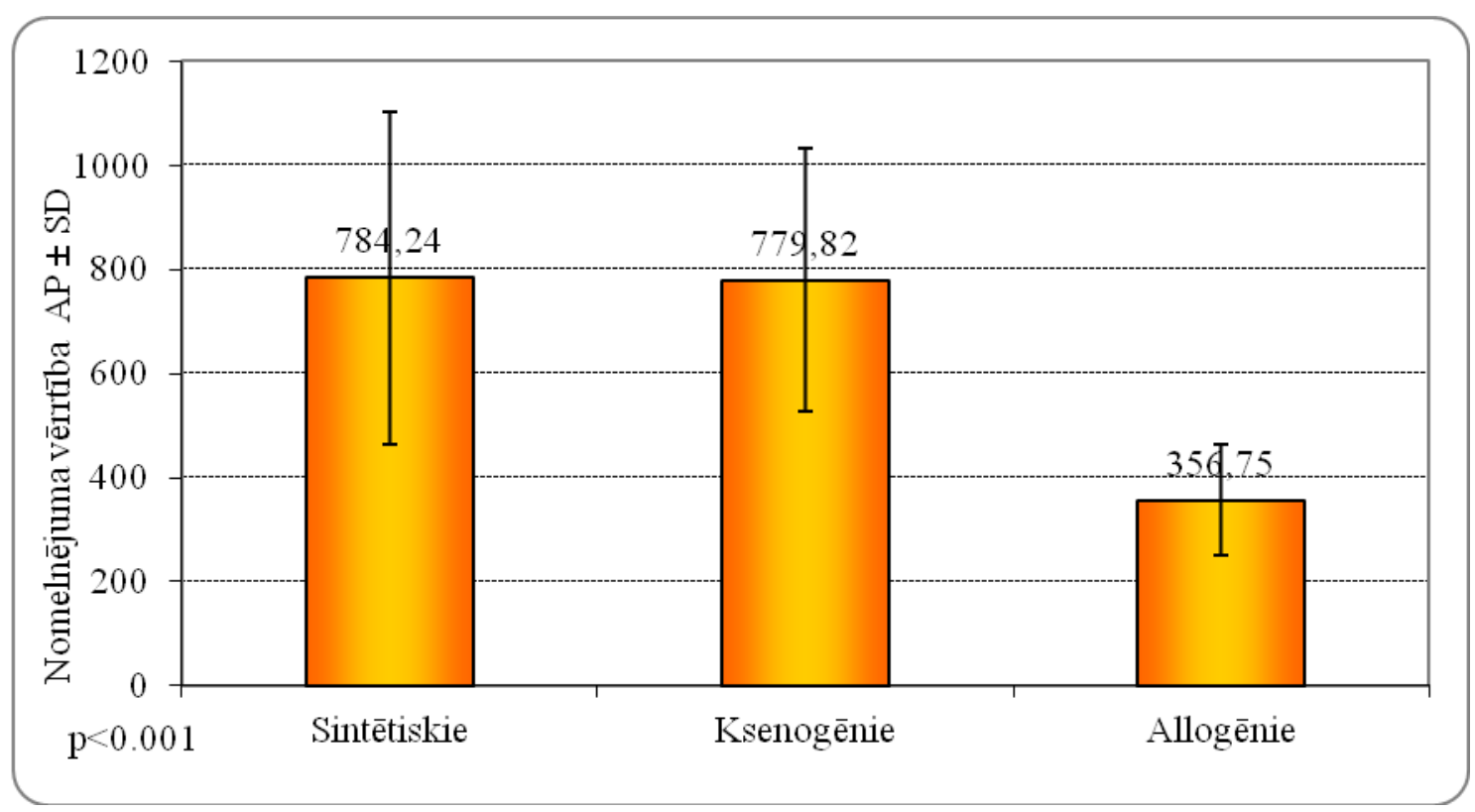

6.16. att. Attēla vidējā nomelnējuma līmeņa salīdzinājums mērījuma punktā AP

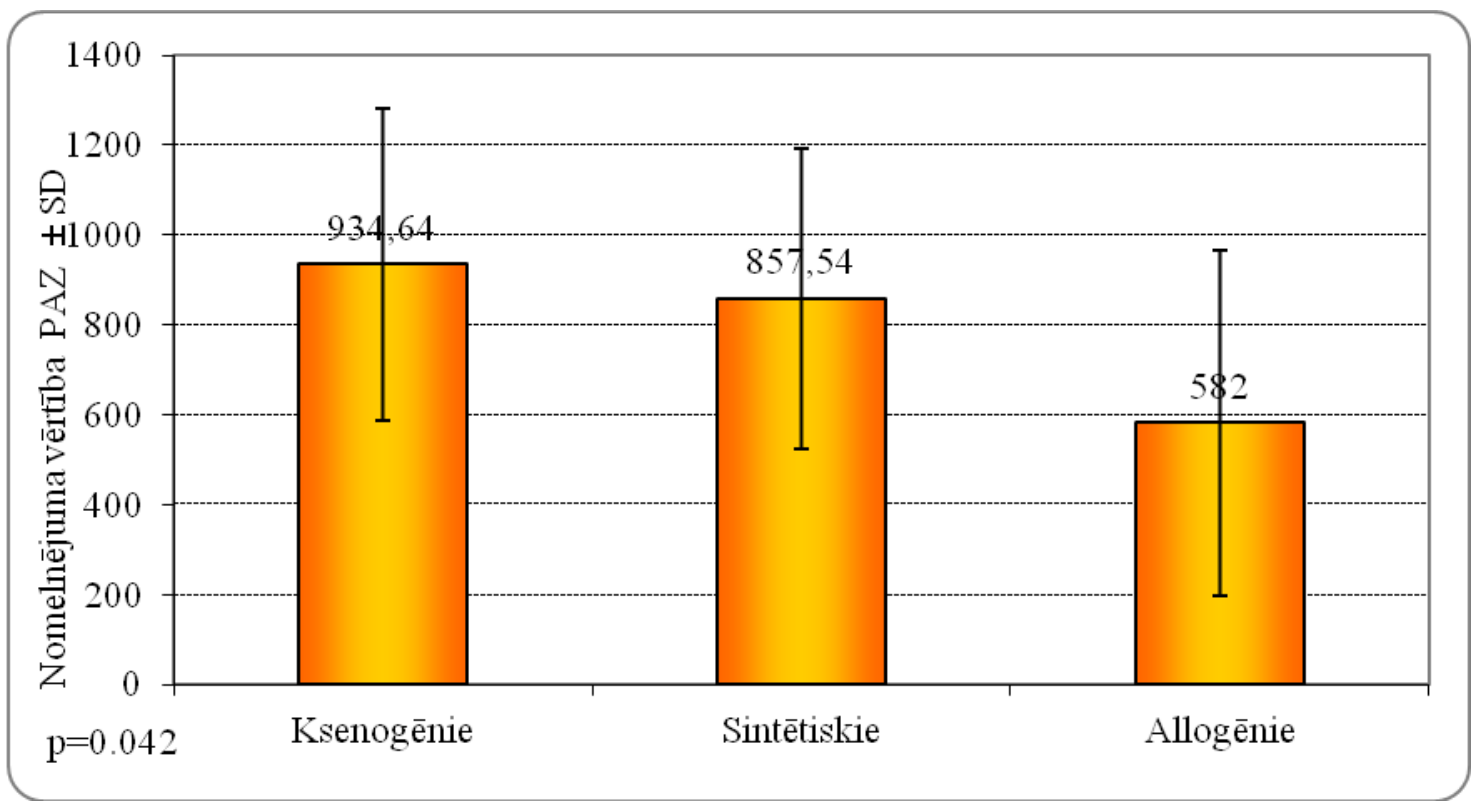

6.17. att. Attēla vidējā nomelnējuma līmeņa salīdzinājums mērījuma punktā PAZ 


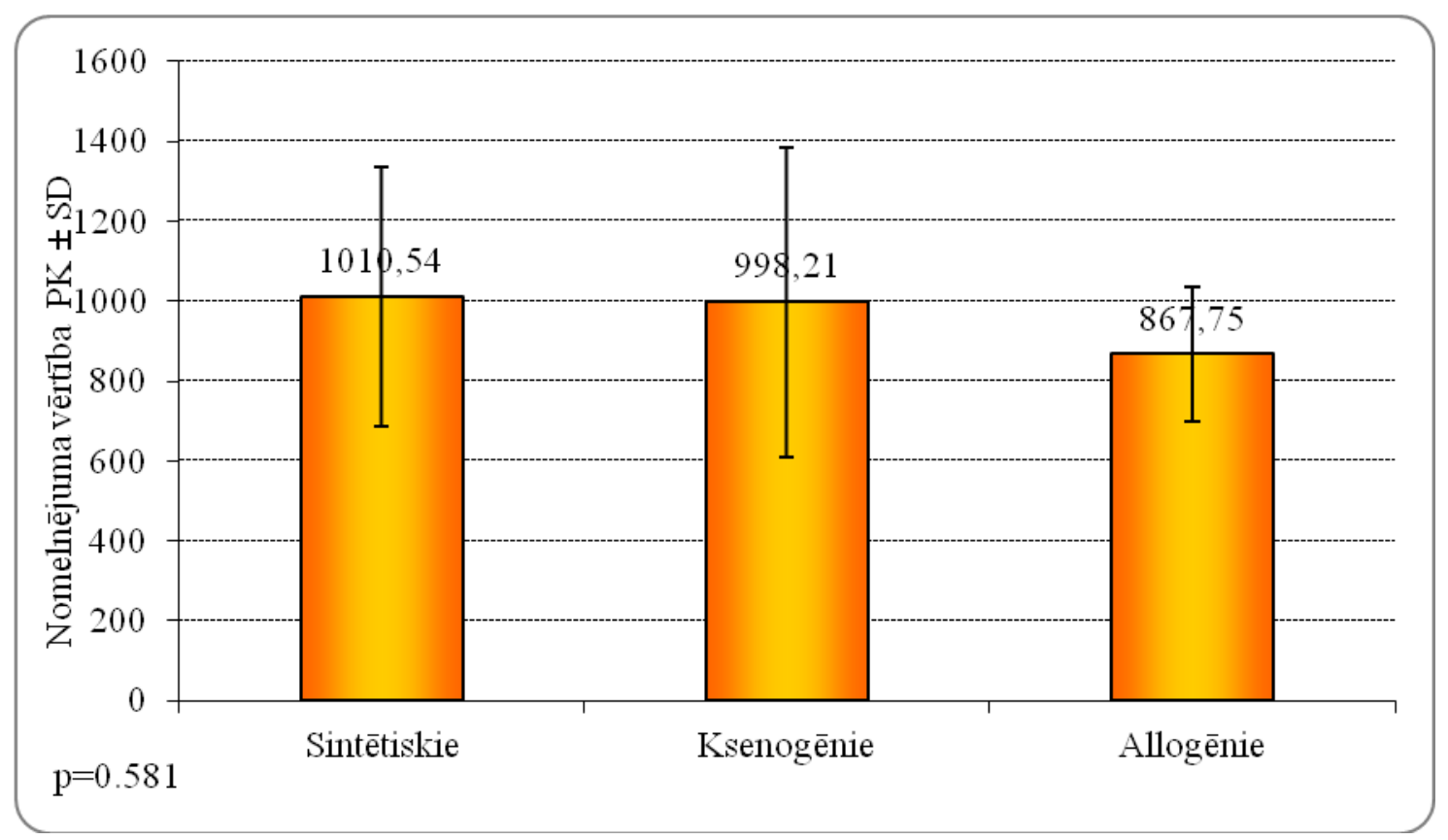

6.18. att. Attēla vidējā nomelnējuma līmeṇa salīdzinājums mērījuma punktā PK

Ar Fišera LSD testu padziļināti analizējot atš̌kirības starp dažādo materiālu grupām pēc radioloǵiskā attēla nomelnējuma līmeņa mērījumu punktiem, tika konstatētas statistiski nozīmīgas atšķkirības punktā BK starp allogēno un ksenogēno materiālu grupām $(\mathrm{p}=0,006)$; punktā BAZ starp allogēno un ksneogēno materiālu grupām ( $\mathrm{p}=0,006)$; allogēno un sintētisko materiālu grupām $(\mathrm{p}=0,001)$; punktā AP starp allogēno un ksenogēno materiālu grupām $(\mathrm{p}<0,0001)$ un allogēno un sintētisko materiālu grupām ( $\mathrm{p}<0,0001)$; punktā PAZ starp allogēno un ksneogēno materiālu grupām $(\mathrm{p}=0,012)$; starp allogēno un sintētisko materiālu grupām $(\mathrm{p}=0,056)$ atšksirība bija tuvu statistiski nozīmīgam rezultātam. Mērījuma punktā PK nevienā no biomateriālu grupu pāriem netika atrasta statistiski nozīmīga atšksirība (6.10. tabula). 
Fišera LSD testa rezultāti

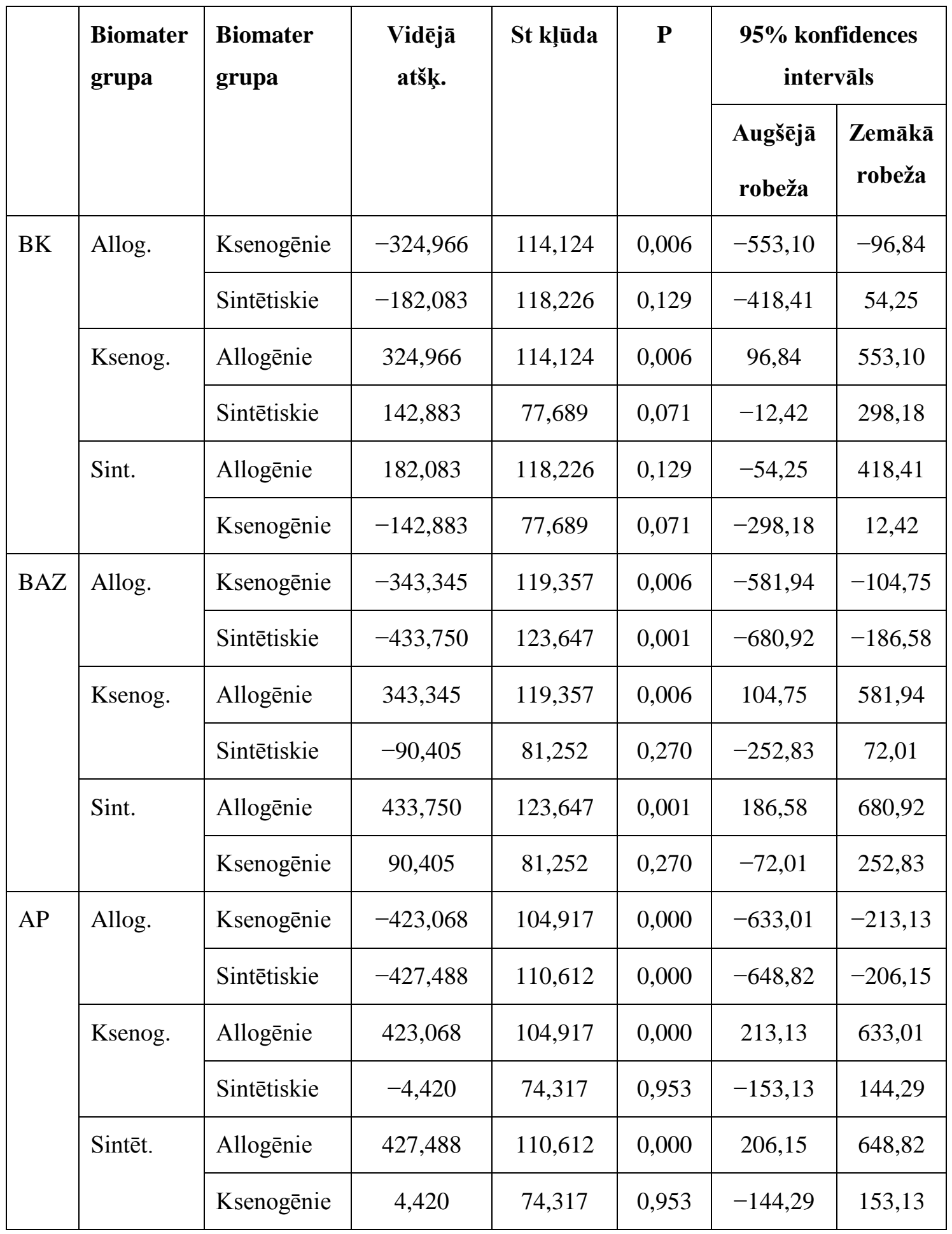

6.10. tabulas trupinājums nākamajā lapā. 
6.10. tabulas trpinājums.

\begin{tabular}{|c|c|c|c|c|c|c|c|}
\hline & \multirow{2}{*}{$\begin{array}{l}\text { Biomat } \\
\text { er } \\
\text { grupa }\end{array}$} & \multirow[t]{2}{*}{$\begin{array}{l}\text { Biomater } \\
\text { grupa }\end{array}$} & \multirow[t]{2}{*}{$\begin{array}{l}\text { Vidējāā } \\
\text { atšķ. }\end{array}$} & \multirow[t]{2}{*}{ St kḷūda } & \multirow[t]{2}{*}{$\mathbf{P}$} & \multicolumn{2}{|c|}{$\begin{array}{c}\text { 95\% konfidences } \\
\text { intervāls }\end{array}$} \\
\hline & & & & & & $\begin{array}{l}\text { Augšējā } \\
\text { robeža }\end{array}$ & $\begin{array}{r}\text { Zemākā } \\
\text { robeža }\end{array}$ \\
\hline \multirow[t]{6}{*}{ PAZ } & \multirow[t]{2}{*}{ Allog. } & Ksenogēnie & $-352,636$ & 136,734 & 0,012 & $-625,96$ & $-79,31$ \\
\hline & & Sintētiskie & $-275,542$ & 141,648 & 0,056 & $-558,69$ & 7,61 \\
\hline & \multirow[t]{2}{*}{ Ksenog. } & Allogēnie & 352,636 & 136,734 & 0,012 & 79,31 & 625,96 \\
\hline & & Sintētiskie & 77,095 & 93,081 & 0,411 & $-108,97$ & 263,16 \\
\hline & \multirow[t]{2}{*}{ Sint. } & Allogēnie & 275,542 & 141,648 & 0,056 & $-7,61$ & 558,69 \\
\hline & & Ksenogēnie & $-77,095$ & 93,081 & 0,411 & $-263,16$ & 108,97 \\
\hline \multirow[t]{6}{*}{ PK } & \multirow[t]{2}{*}{ Allog. } & Ksenogēnie & $-130,462$ & 136,451 & 0,343 & $-403,22$ & 142,30 \\
\hline & & Sintētiskie & $-142,792$ & 141,355 & 0,316 & $-425,36$ & 139,77 \\
\hline & \multirow[t]{2}{*}{ Ksenog. } & Allogēnie & 130,462 & 136,451 & 0,343 & $-142,30$ & 403,22 \\
\hline & & Sintētiskie & $-12,330$ & 92,889 & 0,895 & $-198,01$ & 173,35 \\
\hline & \multirow[t]{2}{*}{ Sint. } & Allogēnie & 142,792 & 141,355 & 0,316 & $-139,77$ & 425,36 \\
\hline & & Ksenogēnie & 12,330 & 98,889 & 0,895 & $-173,35$ & 198,01 \\
\hline
\end{tabular}

Dati tika pakḷauti arī neparametriskajam Kruskala - Valisa H testam, jo allogēno materiālu grupā bija neliels subjektu skaits. Arī pēc šī testa tika iegūtas statistiski nozīmīgas atšķirības starp materiālu grupām visos mērījumu punktos, izṇemot PK.

Veicot korelācijas analīzi ar pirms operācijas mērījumiem, tika iegūta negatīva statistiski ticama korelācija starp kaula augstuma mērījumiem pirms operācijas un kaula nomelnējuma vērtību BK punktā pēc operācijas mērījumos $(\mathrm{r}=-0,251, \mathrm{p}=0,043)$. Korelācijas analīzē ar kaula augstumu tika pielietota neparametriskā Spīrmena korelācijas analīze, jo kaula augstuma mērījumi neatbilda normālam datu sadalījumam

Trīspadsmit dobumos pamatnes paaugstināšanas operācijas laikā netika ievietoti implantāti - 2 etapu ADPP ar zobu implantātu ievietošanu otrajā operācijas etapā. 
Implantātu ievietošana tika paredzēta atkārtotas operācijas laikā. Iegūtie kaula (K) un augmentētās zonas (AZ) vidējie nomelnējuma līmeņa mērījumi apkopoti 6.11. tabulā.

6.11. tabula

Vidējie kaula un augmentētās zonas radiologiskā attēla nomelnējuma

līmeṇa vērtības mērījumi divu etapu operācijas gadījumā

\begin{tabular}{|l|c|c|}
\hline & K & BZ \\
\hline $\mathrm{N}$ & 13 & 13 \\
\hline Vidējais & 335,38 & 876,62 \\
\hline $\mathrm{SD}$ & 278,847 & 181,905 \\
\hline Mediāna & 213,00 & 891,00 \\
\hline Minimālais & -35 & 614 \\
\hline Maksimālais & 912 & 1129 \\
\hline
\end{tabular}

Salīdzināšanā un datu analīzē skaitliski mazās grupas dēḷ tika izmantotas neparametriskās statistiskās metodes. Tika salīdzināts reziduālā alveolārā izauguma radiologíiskā attēla nomelnējuma līmenis pirms operācijas un pēc operācijas (6.12. tabula).

6.12. tabula

Kaula radiologiiskā attēla nomelnējuma līmeņa vērtība bez implantāta pētījuma grupā

\begin{tabular}{|c|c|c|c|c|c|c|c|c|}
\hline & \multirow[t]{2}{*}{$\mathbf{N}$} & \multirow{2}{*}{$\begin{array}{c}\text { Vidējais } \\
(\mathrm{VV})\end{array}$} & \multirow[t]{2}{*}{ SD } & \multirow[t]{2}{*}{ Minim } & \multirow[t]{2}{*}{ Maksim } & \multicolumn{3}{|c|}{ Percentīles } \\
\hline & & & & & & $25 t a ̄$ & $\begin{array}{c}50 t a ̄ \\
\text { (mediāna) }\end{array}$ & 75 tā \\
\hline $\begin{array}{l}\text { Pirms } \\
\text { oper. }\end{array}$ & 13 & 140,69 & 216,159 & -170 & 488 & $-40,50$ & 79,00 & 379,5 \\
\hline
\end{tabular}

6.12. tabulas turpinājums nākamajā lapā. 
6.12. tabulas turpinājums

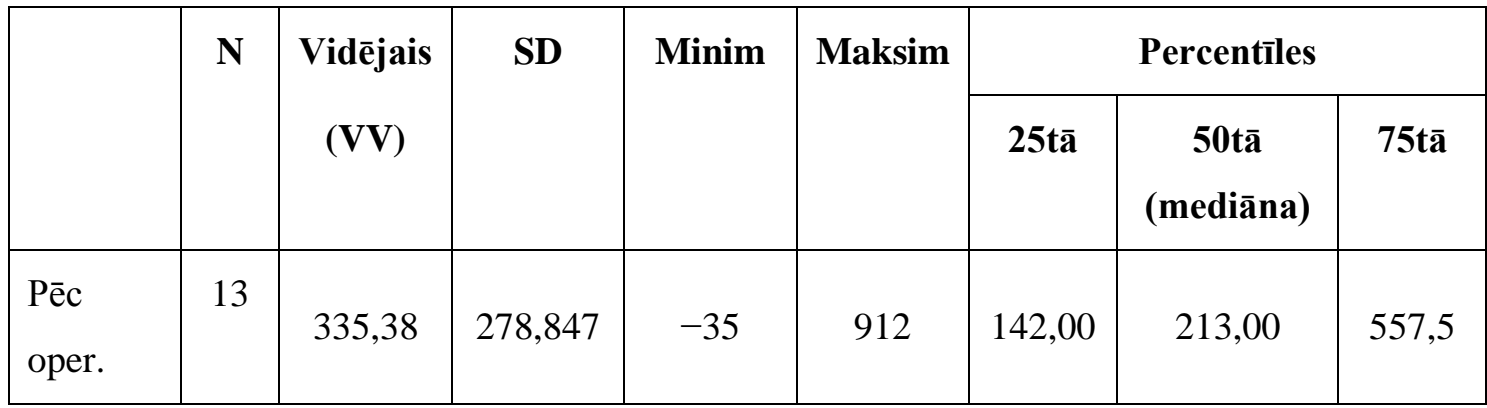

Vilkoksona testa rezultāti uzrādīja statistiski ticamu atšķirību starp kaula radiologisiskā attēla nomelnējuma līmeņa rezultātiem pirms un pēc operācijas $(p=0,007)$ (6.19. attēls).

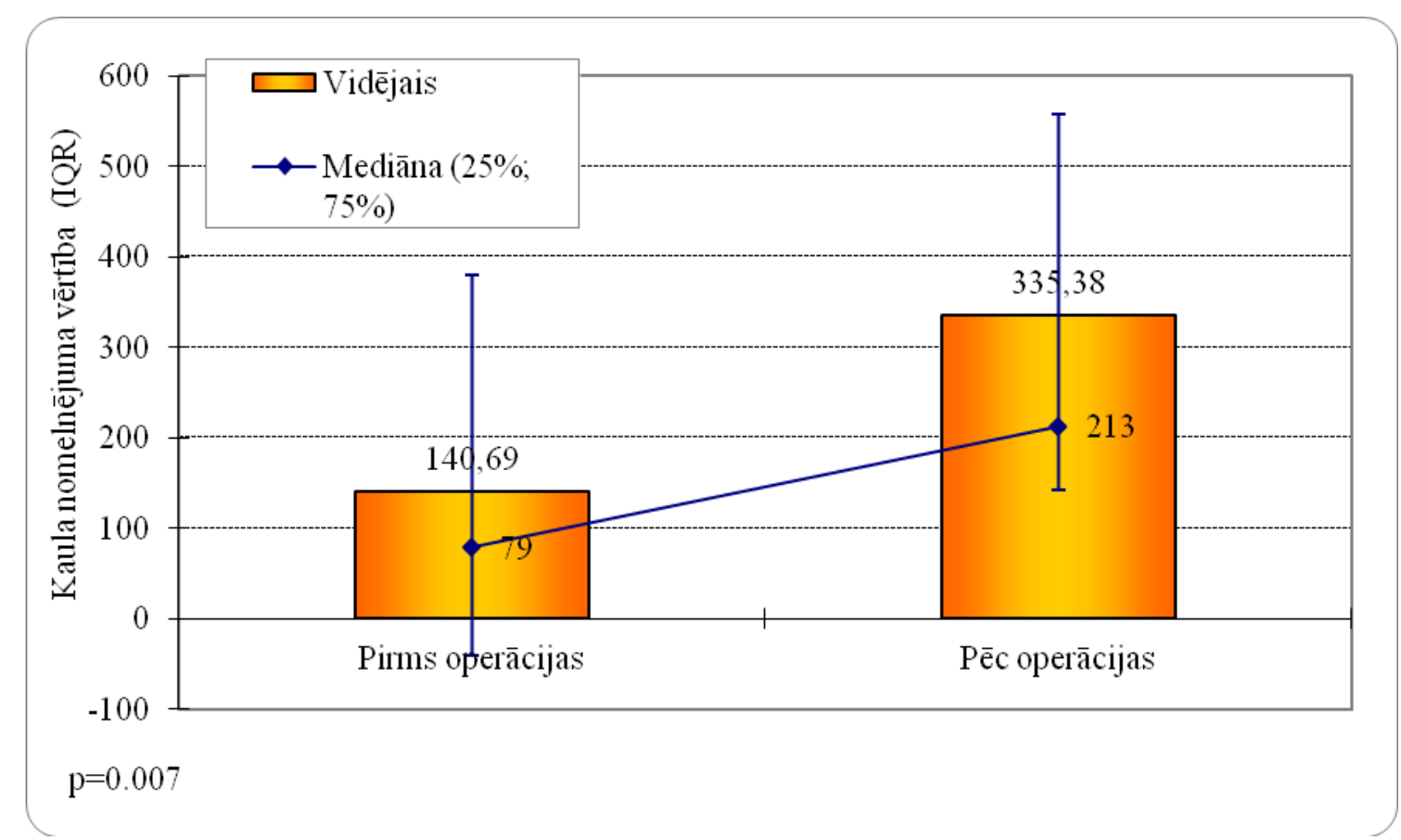

6.19. att. Kaula radiologiskā attēla nomelnējuma līmeṇa vērtības mērījumi pirms un pēc operācijas

Kontroles grupā ap implantātu tika noteikta kaula radioloǵiskā attēla nomelnējuma līmeņa vērtība piecos punktos līdzịgi kā pētījuma grupā ar implantātu. Kontroles grupā visi mērījumi tika veikti kaulā, jo implantāti bija ievietoti kaulā bez biomateriālu lietošanas. Iegūtie rezultāti apkopoti 6.13. tabulā. 
6.13. tabula

Kontroles grupas radiologiiskā attēla nomelnējuma līmeņa mērījumu aprakstošāa statistiska

\begin{tabular}{|l|l|c|c|c|c|c|}
\hline \multicolumn{2}{|l|}{} & BKM & BKK & AP & PKK & PKM \\
\hline \multirow{2}{*}{ N } & Esošie & 33 & 37 & 31 & 37 & 37 \\
\cline { 2 - 7 } & Iztrūkstošie & 4 & 0 & 6 & 0 & 0 \\
\hline Vidējais & 867,85 & 817,35 & 434,87 & 645,27 & 908,46 \\
\hline Mediāna & 782,00 & 779,00 & 384,00 & 667,00 & 878,00 \\
\hline SD & 357,801 & 382,190 & 317,112 & 275,976 & 313,512 \\
\hline Minimālais & 97 & -110 & -192 & 91 & 222 \\
\hline Maksimalais & 1696 & 1686 & 1151 & 1135 & 1668 \\
\hline
\end{tabular}

Pētījuma gaitā izveidojās trīs šādas grupas: kontroles grupa, kurā augšžokḷa kaulā zoba implantāts tika ievietots kaulā (kontroles grupa); pētījuma grupa bez implantāta, jo tika veikta divu etapu ķirurğija; pētījuma grupa ar implantātu, kurā augšžokḷa dobuma pamatnes paaugstināšanas gaitā vienlaicīgi tika ievietoti arī zobu implantāti. Kontroles grupā bija 37, pêtījuma grupā bez implantāta - 13 un pētījuma grupā ar implantātu - 65 subjekti. Pēc operācijas izmeklējumā tika salīdzināts kaula radiologiskais nomelnējuma līmeņa pieaugums visās grupās. Pētījuma grupā ar implantātu salīdzināšanai tika atlasīti mērījumi PK un BK punktos, pētījuma grupā bez implantāta - K mērījuma punktā, bet kontroles grupā - BKM un PKM mērījuma punktos. No pēc operācijas izmeklējumā iegūtiem nomelnējuma līmeņa datiem minētajos punktos tika atņemts pirms operācijas izmeklējumā reǵistrētais kaula radiolog̣iskā nomelnējuma līmenis. Tādējādi tika iegūts kaula radiolog̣iskā nomelnējuma vērtības pieaugums: pētījuma grupā ar implantātu BK tas bija 994,18 SD $\pm 336,478 \mathrm{VV}, \mathrm{PK}$ 845,55 SD \pm 369,285; pêtījuma grupā bez zobu implantāta mērījuma punktā K tas bija 194,69 SD \pm 264,768 VV (mediāna 162,00); kontroles grupā BKM mērījuma vietā tas bija 697,58 SD \pm 369,279 VV, PKM 743,30 SD \pm 339,479 VV (6.20. un 6.21. attēls). 


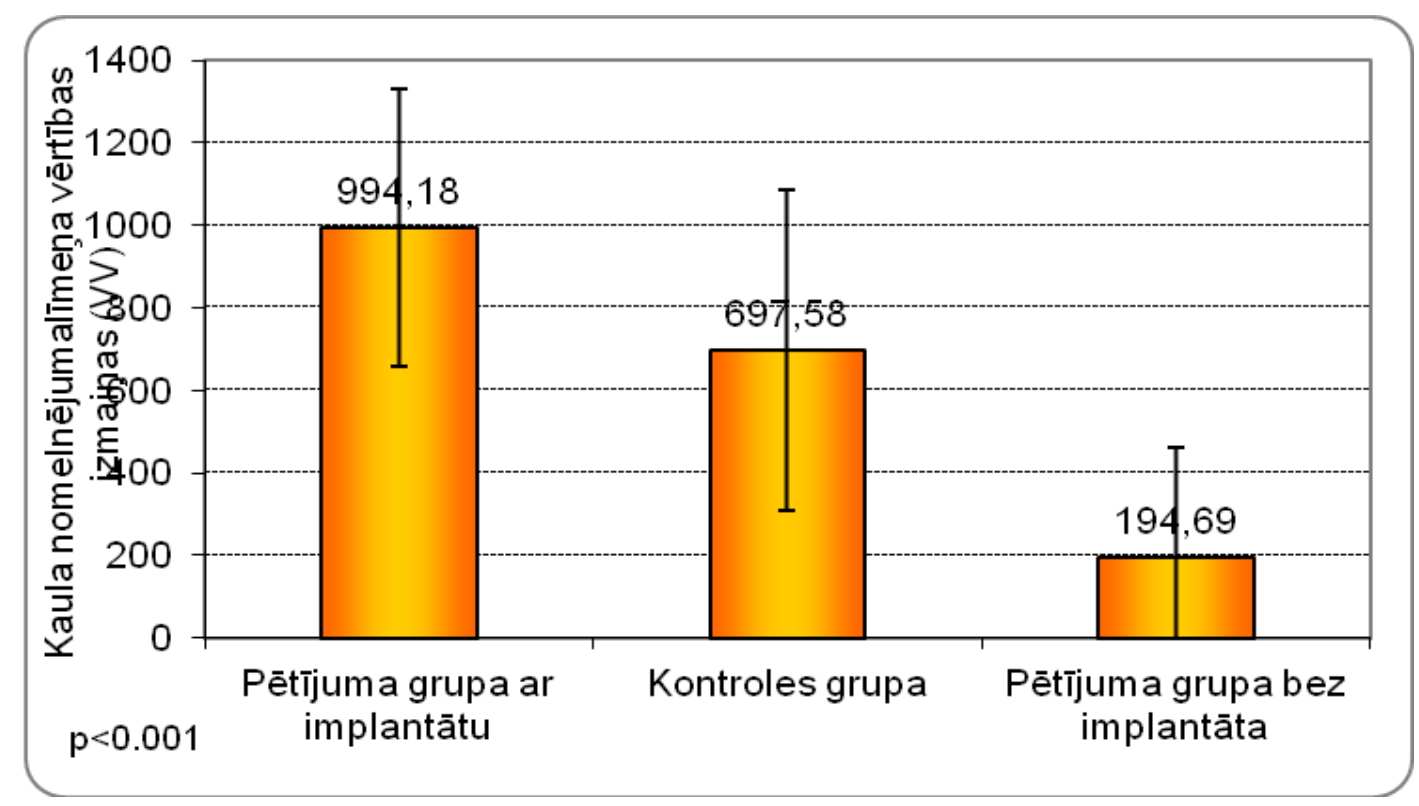

6.20. att. Kaula radioloğiskā nomelnējuma līmeṇa izmaiņas pēc operācijas PK, PKM un K mērījuma vietās

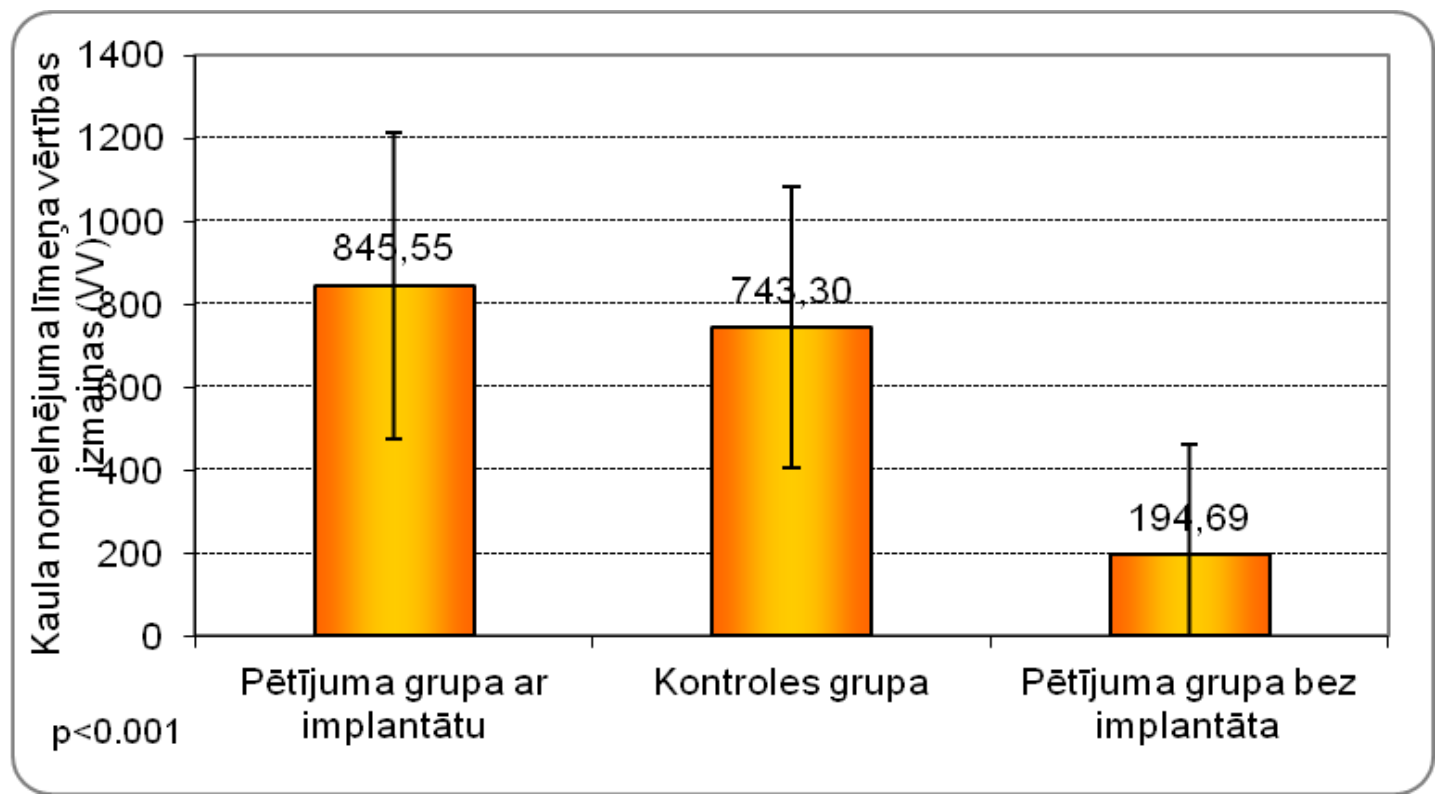

6.21. att. Kaula radioloğiskā nomelnējuma līmeņa izmaiņas pēc operācijas BK, BKM un K mērījuma vietās

Pēc ANOVA testa tika konstatētas statistiski ticamas atšķirības starp visām grupām ( $\mathrm{p}<$ 0,0001). Salīdzinot aprēķinātos kaula nomelnējuma vērtības pieauguma rezultātus starp grupām ar Fišera LSD testu, tika konstatētās statistiski nozīmīgas 
atšķirības starp visu mērījumu pāriem ( $\mathrm{p}<0,0001$ ), izņemot PK un K pārī. Statistiski nozīmīgie rezultāti šksiet loǵiski aplūkojot matemātiski iegūtos datus. No klīniskā viedokḷa nešķiet loǵiski, ka kontroles grupā ap implantātu notiek tādas kaula izmaiņas, kuras var noteikt radiologisiski. Tādēl jādomā, ka tā ir metāla artefaktu ietekme, kas izmaina attēlu un rada šo ,viltus” audu nomelnējuma līmeņa vērtības pieaugumu. Līdzịgi jādomā arī par izteikto nomelnējuma līmeņa pieaugumu pētījuma grupā ar implantātiem. Biomateriālu ietekmei uz nomelnējuma izmaiṇām ir gan klīnisks, gan histologíisks izskaidrojums. Par to liecina arī korelācija starp grupām (6.14. tabula).

6.14. tabula

Korelācija starp kaula radioloğiskā nomelnējuma līmeṇa mērījumiem, biomateriāla un implantāta klātbūtni

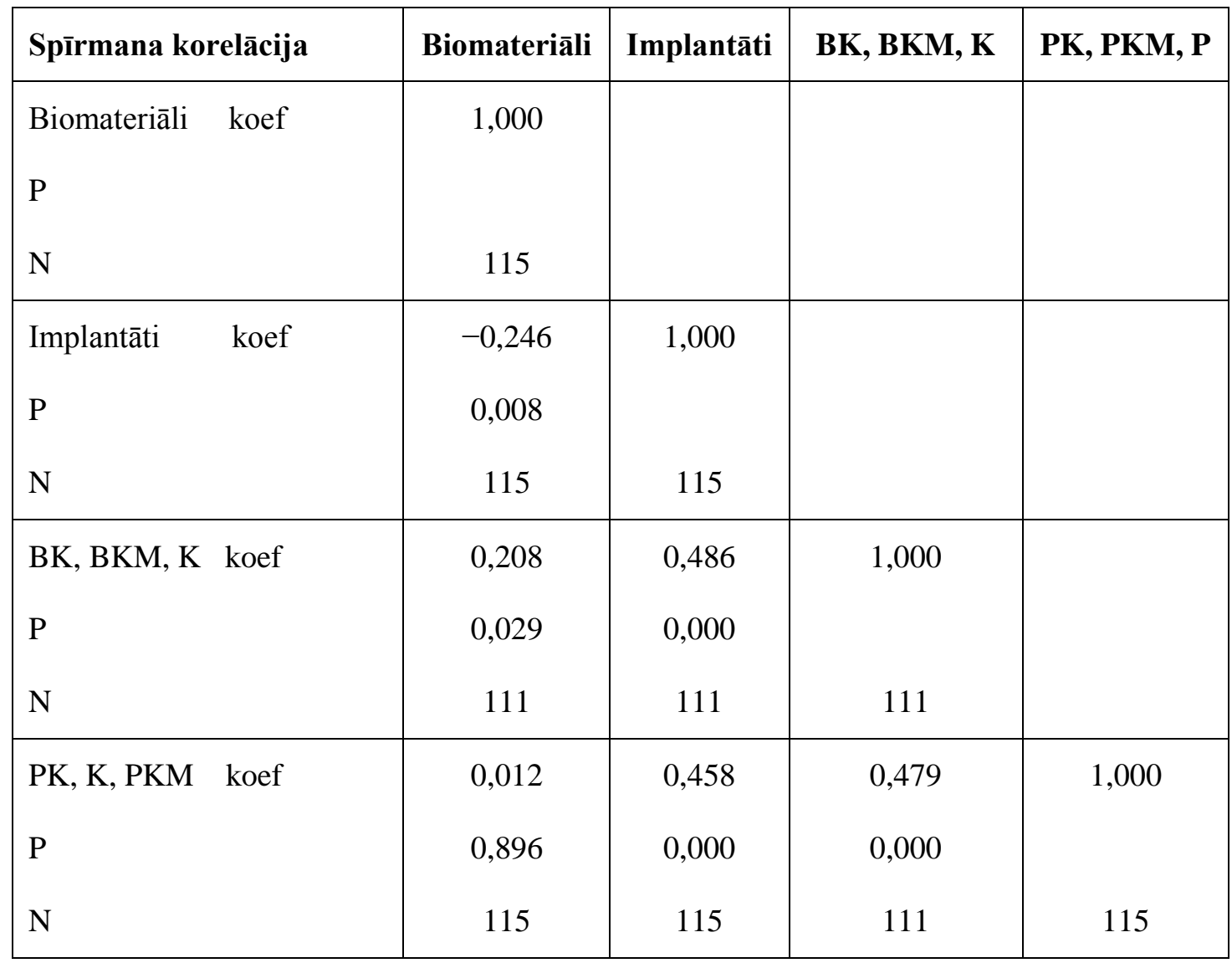

Kā redzams, biomateriālu klātbūtne uzrāda vāju korelāciju ar kaula radiologiiskā nomelnējuma līmeņa pieaugumu BK, K un BKM mērījuma vietās ( $\mathrm{r}=0,208, \mathrm{p}=0,029)$ un pilnīgi nekādu korelāciju ar PK, K un PKM ( $\mathrm{r}=0,012, \mathrm{p}=0,896)$. Toties implantātu 
klātbūtne uzrāda korelāciju, kas ir tuvu vidēji stiprai korelācijai, gan ar PK, K un PKM, gan BK, K, BKM mērījumiem: attiecīgi $r=0,458$, $p<0,0001$ un $r=0,486, p<0,0001$.

Pēc pozitīvu korelācijas datu iegūšanas tika veikta lineārās regresijas analīze atsevišķi BK, K, BKM un PK, K, PKM grupām atkarībā no predikatoriem biomateriāliem un implantātiem. BK, K, BKM grupas izveidotais lineārais regresijas modelis izrādījās statistiski nozīmīgs, un tas var tikt pielietots praksē (ANOVA, $\mathrm{p}<0,0001)(6.15$. tabula).

6.15. tabula

Mērījumu zonu BK, K, BKM radiologiiskā nomelnējuma līmeṇa vērtības atkarība no implantātu un biomateriālu klātbūtnes lineārajā regresijāā

\begin{tabular}{|c|c|c|c|c|c|c|c|}
\hline \multirow{2}{*}{ Modelis } & \multicolumn{2}{|c|}{$\begin{array}{c}\text { Nestandarta } \\
\text { koeficients }\end{array}$} & \multirow{2}{*}{$\begin{array}{c}\begin{array}{c}\text { Standarta } \\
\text { koeficient } \\
\text { s }\end{array} \\
\text { Beta }\end{array}$} & \multirow{2}{*}{$\mathbf{t}$} & \multirow{2}{*}{$\mathbf{p}$} & \multicolumn{2}{|c|}{ Kolinearitāte } \\
\hline & B & $\begin{array}{c}\text { Std } \\
\text { klū }\end{array}$ & & & & Tolerance & VIF \\
\hline 1 & $-101,917$ & 121,188 & & $-0,841$ & 0,402 & & \\
\hline Biomateriāli & 296,609 & 73,976 & 0,316 & 4,010 & 0,000 & 0,944 & 1,059 \\
\hline Implantāti & 799,492 & 105,151 & 0,599 & 7,603 & 0,000 & 0,944 & 1,059 \\
\hline
\end{tabular}

Biomateriālu un implantātu klātbūtnes esamība radiologiskajos attēlos rada nomelnējuma vērtības pieaugumu, kas ir vairāk izteikts tieši implantātam BK, K, BKM grupā. Pēc lineārās regresijas rezultātiem var secināt, ka implantāta klātbūtne radiologiiskajos KSDT izmeklējumos palielina nomelnējuma vērtību bukāli no implantāta par 799,492 VV, bet biomateriālu klātbūtne palielina to par 296,609 VV. Tādējādi, lai iegūtu precīzu kaula izmaiņu pieaugumu bukāli no implantāta, kuru neveido implantātu artefakti, veicot nomelnējuma līmeņa mērījumus ar KSDT no uzrādītā rezultāta būtu jāatņem 799,492.

PK, K, PKM grupu izveidotais lineārais regresijas modelis izrādījās (6.16. tabula) statistiski nozīmīgs un tas var tikt pielietots praksē (ANOVA, $\mathrm{p}<0,0001$ ). Implantātu klātbūtnes esamība radiologiskos attēlos rada audu nomelnējuma līmeņa vērtības pieaugumu arī PK, K, PKM grupā. Pēc lineārās regresijas rezultātiem var secināt, ka 
6.16. tabula

Mērījumu zonu PK, K, PKM radioloğiskā nomelnējuma līmeņa vērtības atkarība no implantātu un biomateriālu klātbūtnes lineārajā regresijā

\begin{tabular}{|l|c|c|c|c|c|c|c|}
\hline \multirow{2}{*}{ Modelis } & \multicolumn{2}{|c|}{$\begin{array}{c}\text { Nestandarta } \\
\text { koeficients }\end{array}$} & $\begin{array}{c}\text { Standarta } \\
\text { koeficients }\end{array}$ & \multirow{2}{*}{$\mathbf{t}$} & \multirow{2}{*}{$\mathbf{p}$} & \multicolumn{2}{|c|}{ Kolinearitāte } \\
\cline { 2 - 4 } \cline { 6 - 8 } & B & $\begin{array}{c}\text { Std } \\
\text { kḷūda }\end{array}$ & Beta & & & Tolerance & VIF \\
\hline 1 & 92,436 & 120,897 & & 0,765 & 0,446 & & \\
\hline Biomateriāli & 102,257 & 72,074 & 0,120 & 1,419 & 0,159 & 0,940 & 1,064 \\
\hline Implatāti & 650,862 & 106,329 & 0,517 & 6,121 & 0,000 & 0,940 & 1,064 \\
\hline
\end{tabular}

implantāta klātbūtne radioloǵiskos KSDT izmeklējumos palielina radioloǵisko audu nomelnējuma vērtību palatināli no implantāta par 650,862 VV. Biomateriālu klātbūtnes palielinājums nav statistiski nozīmīgs. Līdzīgi, lai precīzi noteiktu kaula līmeņa pieaugumu palatināli no ievietotiem implantātiem, no KSDT iegūtiem nomelnējuma līmeņa mērījumiem ir jāatņem 650,862 vienības.

Salīdzinot abu pētījumu grupu radiologísko mērījumu rezultātus statistiski nozīmīga atšksirība tika konstatēta tikai AP mērījuma vietā (Stjūdenta $\mathrm{t}$ - tests, $\mathrm{p}=0,004)$. Pārbaudot implantātu klātbūtnes ietekmi uz audu radioloǵiskā nomelnējuma līmeņa pieaugumu tika atrasta ļoti vāja, negatīva korelācija ar AP mērījumiem ( $r=-0,278, p=0,024)$. Lineārās regresijas analīzes modeḷi nevienā no mērījumiem, kas izdarīts ap implantātu augmentētajā zonā statistiski ticamus rezultātus neuzrādīja.

Lai noteiktu abu pētījumu grupu augmentētās zonas radiolog̣iskā nomelnējuma līmeņa izmaiņas, no to pēcoperāciju mērījumos iegūtā vidējā lieluma atņēma biomateriālu radioloǵisko nomelnējuma līmeni. Biomateriālu radioloǵiskais nomelnējuma līmenis tika iegūts ar KSDT skenējot materiālu iepakojumus (6.22.-6.25. attēls). 


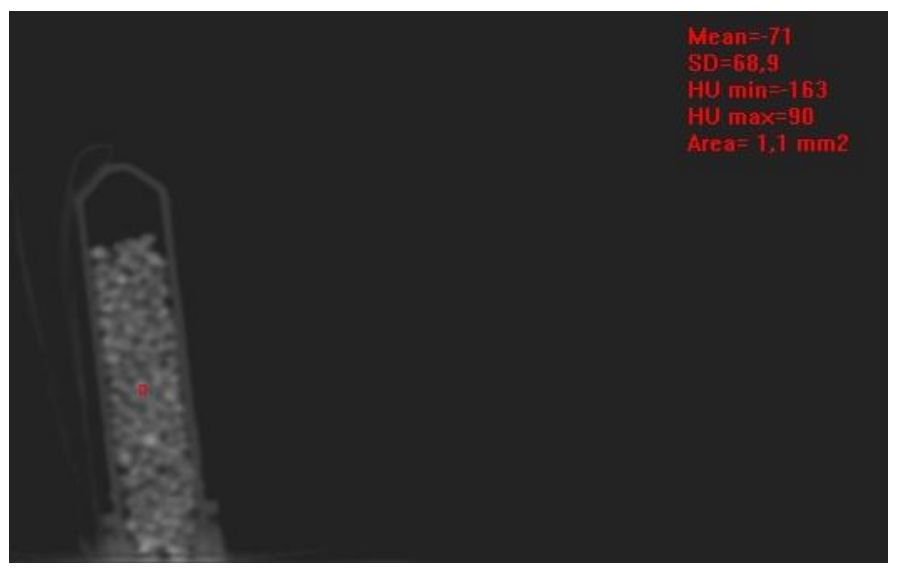

6.22. att. $4 B o n e ~ S B S$ radiologiskā attēla nomelnējuma noteikšana ar KSDT

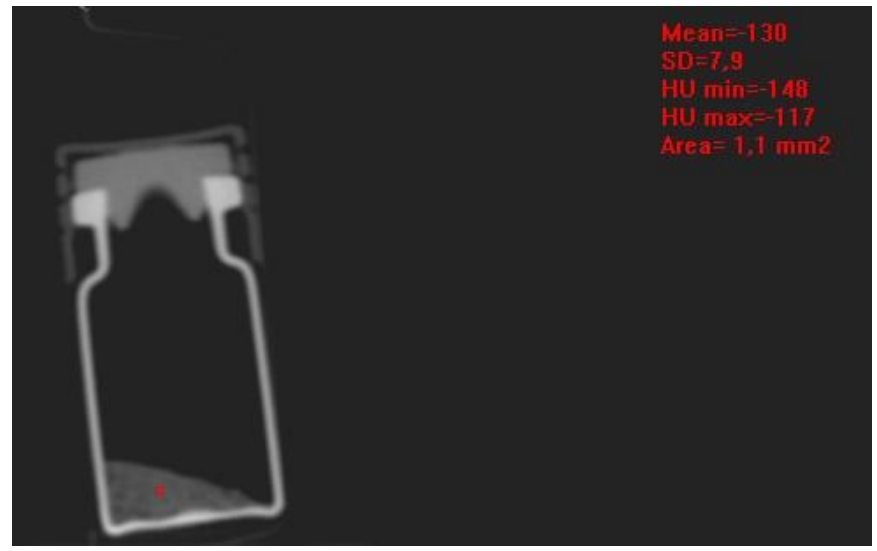

6.23. att. Bio-Oss radiologiskāa attēla nomelnējuma noteikšana ar KSDT

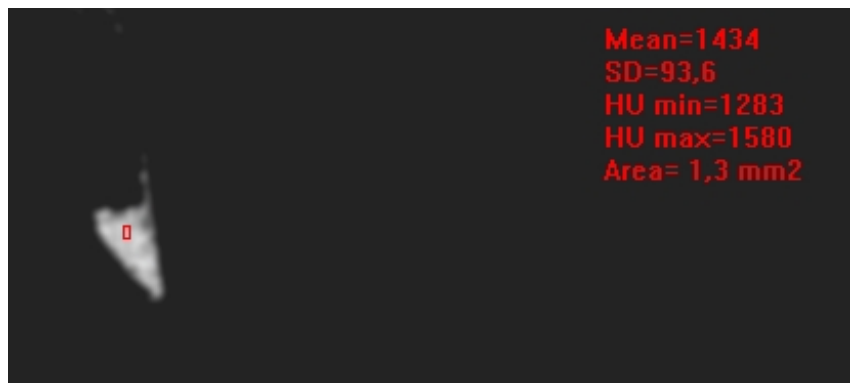

6.24. att. RTU hidroksiapatīta biokeramikas materiāla (HAp/TCP 90/10) radiologiskā attēla nomelnējuma noteikšana ar KSDT 


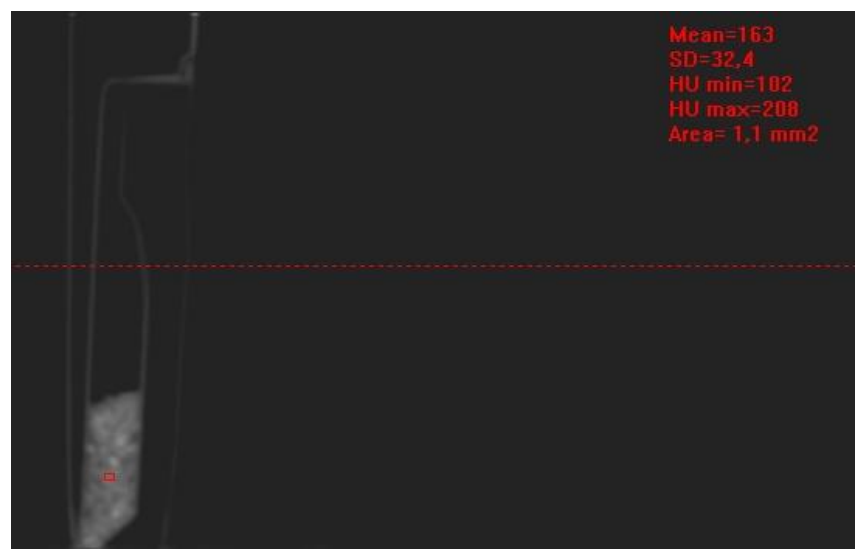

\subsection{5. att. Straumann BoneCeramic radiolog̣iskā attēla nomelnējuma noteikšana ar KSDT}

Tutodent netika skenēts, jo Latvijas tirgū tas vairs nav pieejams. Tutodent gadījumi tika izslēgti no šīs statistiskās analīzes. Pēc tam tika noteikts materiālu radiologiiskā nomelnējuma līmenis (6.17. tabula).

6.17. tabula

\section{Biomateriālu noteiktā radiologiiskā nomelnējuma līmeṇa vērtība}

\begin{tabular}{|l|c|}
\hline Biomateriāls & Nomelnējuma lìmenis \\
\hline Bio-Oss & -130 \\
\hline Straumann BoneCeramic & 163 \\
\hline RTU HAp/TCP & 1434 \\
\hline 4Bone SBS & -71 \\
\hline
\end{tabular}

Atņemot iegūtās biomateriālu nomelnējuma līmeņa vērtības no augmentētās zonas radioloǵiskā nomelnējuma līmeņa mērījumiem pētījuma grupā ar implantātiem tika iegūti dati, kas atbilda normālam sadalījumam ( $\mathrm{p}>0,05)$. Te tika iekḷauta arī pētījumu grupa bez implantātiem, attiecībā uz kuru statistiskajā analīzē nelielā skaita dēl tika pielietoti neparametriskie testi (6.18. tabula). 
6.18 . tabula

Izmaiṇas augmentētās zonas radioloǵiskajā nomelnējuma līmeṇa vērtībā, atṇemot biomateriālu nomelnējuma līmen̦a vērtību

\begin{tabular}{|l|l|l|l|l|}
\hline & BAZ & AP & PAZ & AZ \\
\hline N & 57 & 54 & 57 & 12 \\
\hline N-zudušie & 8 & 11 & 8 & 1 \\
\hline Vidējais & 1082,58 & 815,61 & 939,72 & 1028,50 \\
\hline Mediāna & 1198,00 & 847,5 & 928,00 & 1059,00 \\
\hline SD & 394,953 & 367,536 & 415,274 & 171,189 \\
\hline Minimālais & -410 & -460 & -611 & 769 \\
\hline Maksimālais & 1769 & 1536 & 1954 & 1259 \\
\hline
\end{tabular}

Korelējot iegūtos rezultātus ar laiku, kāds bija pagājis kopš augmentācijas operācijas veikšanas pētījuma grupā bez implantāta netika konstatēta korelācija starp abiem lielumiem. Pētījuma grupā ar implantātu tika konstatētas negatīvas korelācijas visos trīs (BAZ, AP, PAZ) mērījumu punktos attiecībā pret laiku, kāds pagājis kopš ADPP operācijas. Tika pielietota Pīrsona korelācijas analīze un iegūtie rezultāti ir šādi: BAZ r $=-0,509, \mathrm{p}<0,0001$ (6.26. attēls), AP r = -0,274, p = 0,0454 (6.27. attēls), PAZ $\mathrm{r}=-0,313, \mathrm{p}=0,018$ (6.28. attēls). 


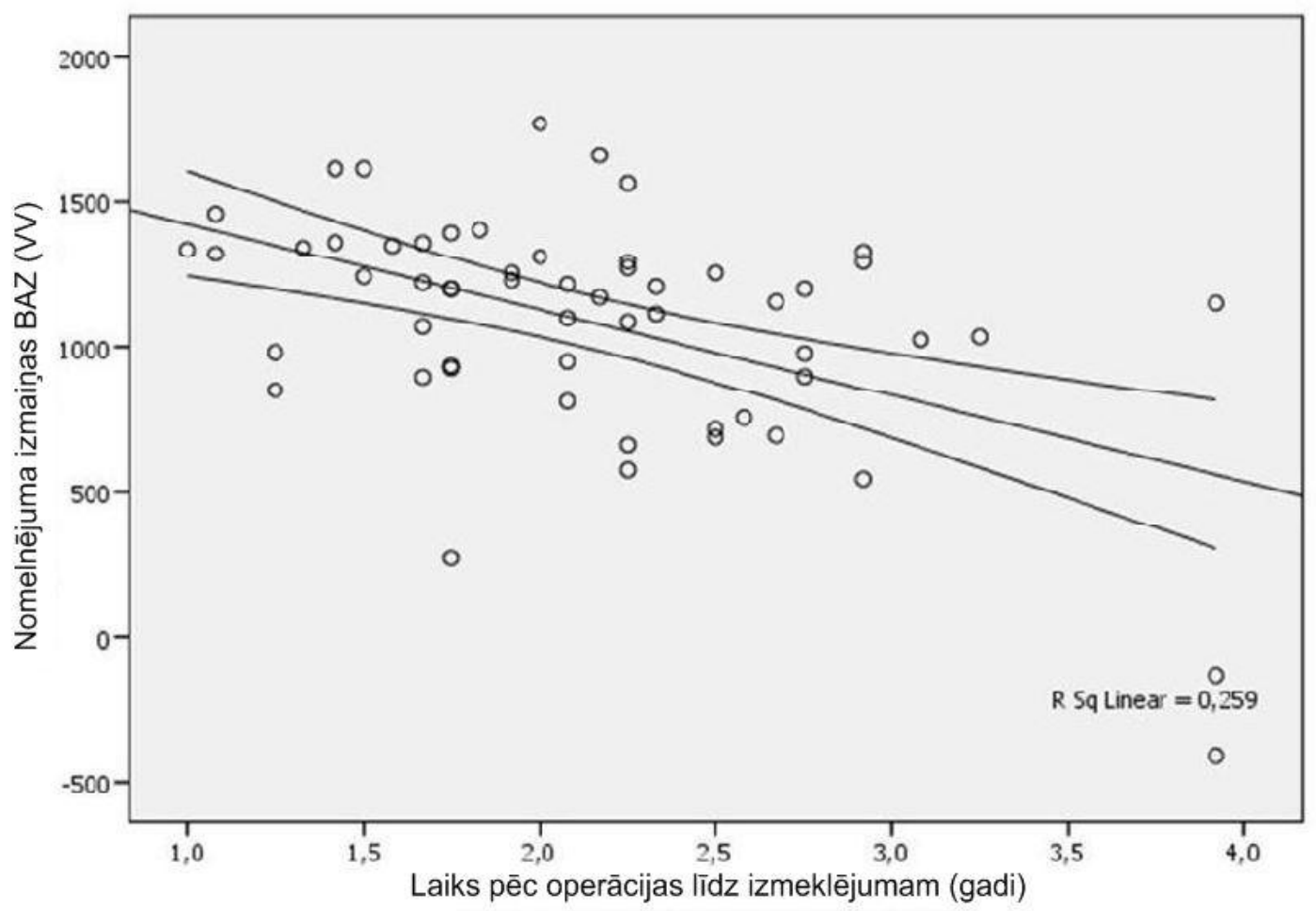

6. 26. att. Korelācijas līkne BAZ mērījuma vietā laika gaitā

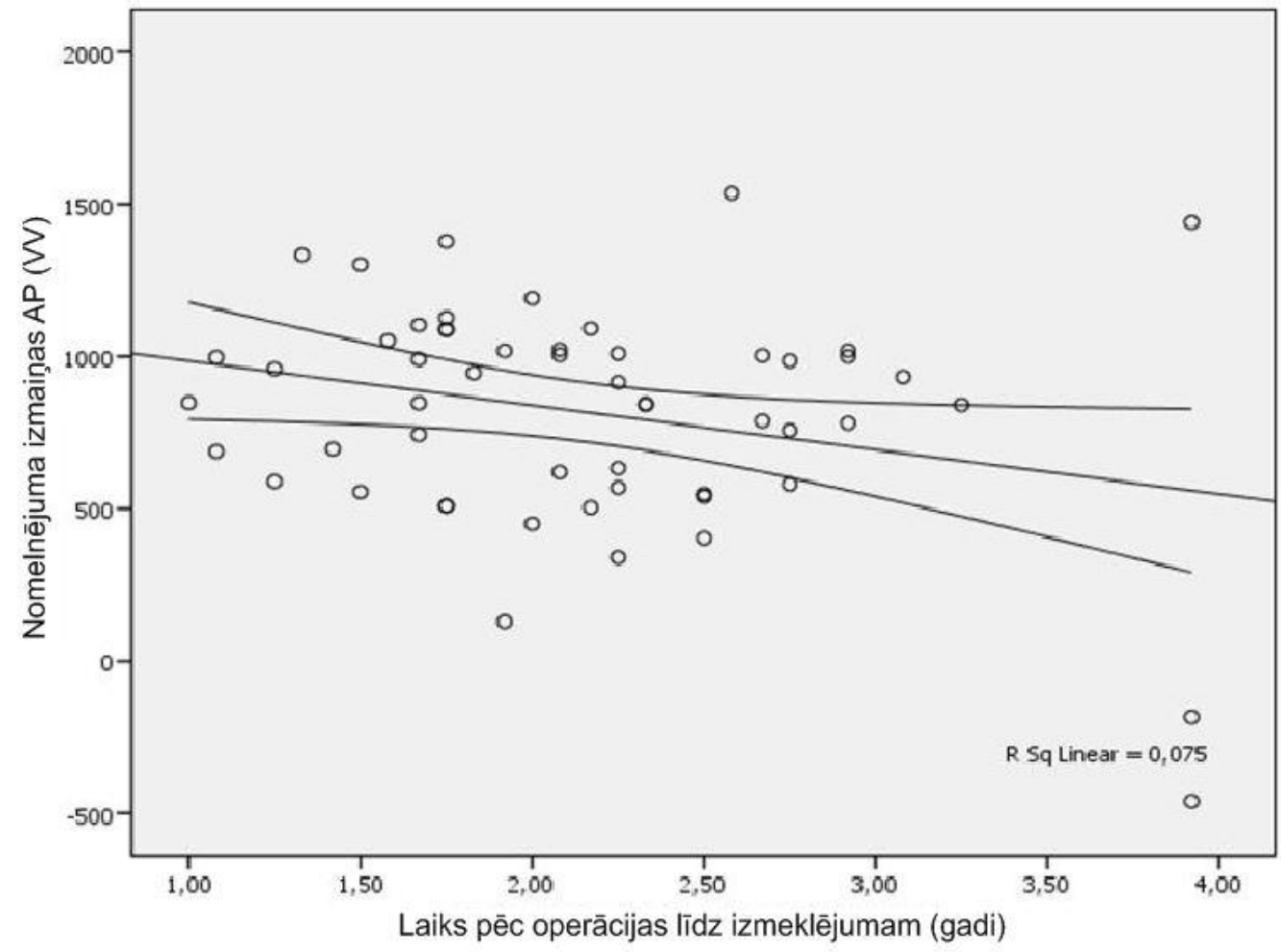

6.27.att. Korelācijas līkne AP mērījuma vietā laika gaitā 


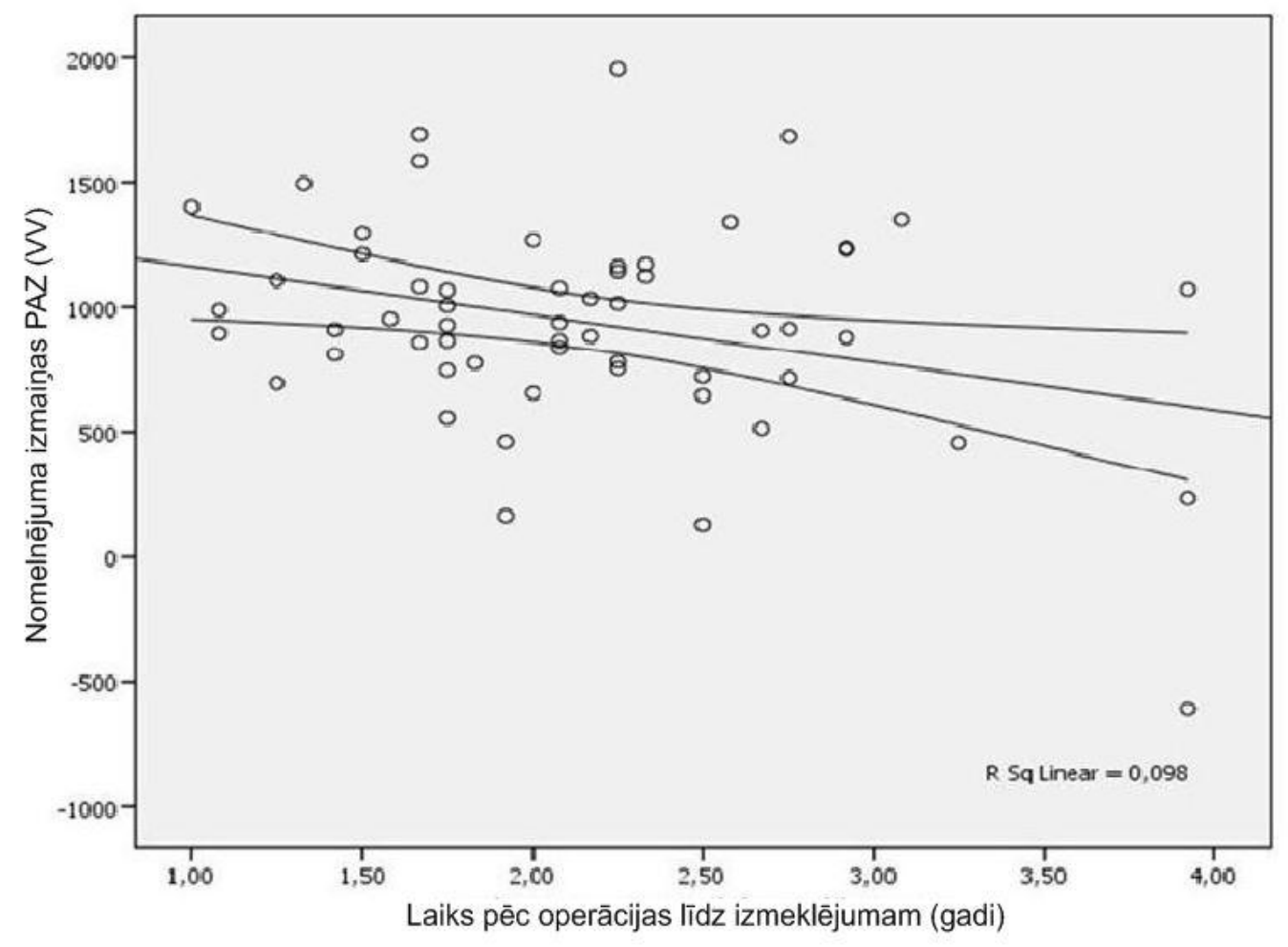

6.28. att. Korelācijas līkne PAZ mērījuma vietā laika gaitā

Salīdzinot korelācijas datus pēc dzimumiem, tika iegūti vēl stiprākas korelācijas dati sievietēm, turpretī vīriešu grupā korelācija netika konstatēta nevienā mērījumu punktā (6.19. tabula).

6.19. tabula

Korelācija starp laiku un radioloğiskā nomelnējuma līmeṇa vērtības izmaiṇām pēc dzimumiem

\begin{tabular}{|l|l|l|c|c|c|c|}
\hline \multicolumn{2}{|l|}{} & BAZ & AP & PAZ & Laiks \\
\hline Sieviete & BAZ & Pīrsona kor & 1 & & & \\
& & P & & & & \\
N & 35 & & & \\
\hline
\end{tabular}

6.19. tabulas turpinājums nākamajā lapā. 
6.19. tabulas turpinājums.

\begin{tabular}{|c|c|c|c|c|c|c|}
\hline & & & BAZ & $\mathbf{A P}$ & PAZ & Laiks \\
\hline & AP & $\begin{array}{l}\text { Pīrsona kor } \\
\text { P } \\
\text { N }\end{array}$ & $\begin{array}{c}0,610 \\
0,000 \\
34\end{array}$ & 1 & & \\
\hline & PAZ & $\begin{array}{l}\text { Pīrsona kor } \\
\text { P } \\
\text { N }\end{array}$ & $\begin{array}{c}0,585 \\
0,000 \\
35\end{array}$ & $\begin{array}{c}0,687 \\
0,000 \\
34\end{array}$ & $\begin{array}{c}1 \\
35 \\
\end{array}$ & \\
\hline & Laiks & $\begin{array}{l}\text { Pīrsona kor } \\
\text { P } \\
\text { N }\end{array}$ & $\begin{array}{c}-0,550 \\
0,001 \\
35\end{array}$ & $\begin{array}{c}-0,317 \\
0,067 \\
34\end{array}$ & $\begin{array}{c}-0,457 \\
0,006 \\
35\end{array}$ & $\begin{array}{c}1 \\
46 \\
4\end{array}$ \\
\hline Vīrietis & BAZ & $\begin{array}{l}\text { Pīrsona kor } \\
\text { P } \\
\text { N }\end{array}$ & 1 & & & \\
\hline & AP & $\begin{array}{l}\text { Pīrsona kor } \\
\text { P } \\
\text { N }\end{array}$ & $\begin{array}{c}0,286 \\
0,221 \\
20\end{array}$ & $\begin{array}{c}1 \\
20\end{array}$ & & \\
\hline & PAZ & $\begin{array}{l}\text { Pīrsona kor } \\
\text { P } \\
\text { N }\end{array}$ & $\begin{array}{c}0,147 \\
0,515 \\
22\end{array}$ & $\begin{array}{c}0,575 \\
0,008 \\
20\end{array}$ & $\begin{array}{c}1 \\
22\end{array}$ & \\
\hline & Laiks & $\begin{array}{l}\text { Pīrsona kor } \\
\text { P } \\
\text { N }\end{array}$ & $\begin{array}{c}-0,287 \\
0,195 \\
22\end{array}$ & $\begin{array}{c}-0,104 \\
0,662 \\
20\end{array}$ & $\begin{array}{c}0,030 \\
0,893 \\
22\end{array}$ & $\begin{array}{c}1 \\
22\end{array}$ \\
\hline
\end{tabular}

Līdzīgi analizējot biomateriālu radiologiskā nomelnējuma līmeņa vērtības izmaiņas sadalījumā pēc laika, kāds pagājis kopš ADPP operācijas veikšanas, korelācijas analīzē varēja izmantot tikai tos gadījumus, kad tika izmantots Bio-Oss, Straumann BoneCeramics un 4Bone SMS, jo bija pietiekams gadījumu skaits. Tā kā 
divās grupās (Straumann BoneCeramics un 4Bone SMS) bija mazāk kā 20 gadījumi, tad tika izmantota Spīrmena neparametriskā korelācijas metode. Bio-Oss grupā vienīgi BAZ mērījuma vietā tika konstatēta korelācija attiecībā pret laiku. Straumann BoneCeramic grupā korelācija pēc laika tika novērota gan AP, gan PAZ mērījumu punktos. 4Bone SMS grupā korelācijas netika novērotas (6.20. tabula).

6.20. tabula

Korelācija augmentētās zonas nomelnējuma līmeņa attiecībā pret pagājušo laiku starp dažādiem biomateriāliem

\begin{tabular}{|c|c|c|c|c|c|c|}
\hline Biomateriāls & & Spīrmena & BAZ & $\mathbf{A P}$ & PAZ & Laiks \\
\hline \multirow[t]{4}{*}{ Bio-Oss } & BAZ & $\begin{array}{l}\text { Korel koef } \\
\text { P } \\
\text { N }\end{array}$ & $\begin{array}{c}1,000 \\
33\end{array}$ & & & \\
\hline & $\mathrm{AP}$ & $\begin{array}{l}\text { Korel koef } \\
\text { P } \\
\text { N }\end{array}$ & $\begin{array}{c}0,262 \\
0,141 \\
33\end{array}$ & $\begin{array}{c}1,000 \\
33\end{array}$ & & \\
\hline & PAZ & $\begin{array}{l}\text { Korel koef } \\
\text { P } \\
\text { N }\end{array}$ & $\begin{array}{c}0,324 \\
0,066 \\
33\end{array}$ & $\begin{array}{c}0,450 \\
0,009 \\
33\end{array}$ & $\begin{array}{c}1,000 \\
33\end{array}$ & \\
\hline & Laiks & $\begin{array}{l}\text { Korel koef } \\
\text { P } \\
\text { N }\end{array}$ & $\begin{array}{c}-0,463 \\
0,007 \\
33\end{array}$ & $\begin{array}{c}0,006 \\
0,973 \\
33\end{array}$ & $\begin{array}{c}-0,116 \\
0,521 \\
33\end{array}$ & $\begin{array}{c}1,000 \\
40\end{array}$ \\
\hline $\begin{array}{l}\text { Straumann } \\
\text { BoneCeramic }\end{array}$ & BAZ & $\begin{array}{l}\text { Korel koef } \\
\text { P } \\
\text { N }\end{array}$ & 1,000 & & & \\
\hline
\end{tabular}

6.20. tabulas turpinājums nākamājā lapā. 
6.20. tabulas turpinājums.

\begin{tabular}{|c|c|c|c|c|c|c|}
\hline \multicolumn{2}{|l|}{ Biomateriāls } & \multirow{2}{*}{$\begin{array}{l}\text { Spīrmena } \\
\text { Korel koef } \\
\text { P } \\
\text { N }\end{array}$} & \multirow{2}{*}{$\begin{array}{c}\text { BAZ } \\
-0,180 \\
0,699 \\
7\end{array}$} & \multirow{2}{*}{$\begin{array}{c}\text { AP } \\
1,000 \\
7\end{array}$} & \multirow[t]{2}{*}{ PAZ } & \multirow[t]{2}{*}{ Laiks } \\
\hline $\begin{array}{l}\text { Straumann } \\
\text { BoneCeramic }\end{array}$ & $\mathrm{AP}$ & & & & & \\
\hline & PAZ & $\begin{array}{l}\text { Korel koef } \\
\text { P } \\
\text { N }\end{array}$ & $\begin{array}{c}-0,523 \\
0,229 \\
7\end{array}$ & $\begin{array}{c}0,821 \\
0,023 \\
7\end{array}$ & $\begin{array}{c}1,000 \\
7\end{array}$ & \\
\hline & Laiks & $\begin{array}{l}\text { Korel koef } \\
\text { P } \\
\text { N }\end{array}$ & $\begin{array}{c}-0,189 \\
0,685 \\
7\end{array}$ & $\begin{array}{c}0,954 \\
0,001 \\
7\end{array}$ & $\begin{array}{c}0,730 \\
0,063 \\
7\end{array}$ & $\begin{array}{c}1,000 \\
7\end{array}$ \\
\hline 4Bone SMS & BAZ & $\begin{array}{l}\text { Korel koef } \\
\text { P } \\
\text { N }\end{array}$ & 1,000 & & & \\
\hline & $\mathrm{AP}$ & $\begin{array}{l}\text { Korel koef } \\
\text { P } \\
\text { N }\end{array}$ & $\begin{array}{c}0,277 \\
0,384 \\
12\end{array}$ & $\begin{array}{c}1,000 \\
12\end{array}$ & & \\
\hline & PAZ & $\begin{array}{l}\text { Korel koef } \\
\text { P } \\
\text { N }\end{array}$ & $\begin{array}{c}0,066 \\
0,815 \\
15\end{array}$ & $\begin{array}{c}0,126 \\
0,697 \\
12\end{array}$ & $\begin{array}{c}1,000 \\
15\end{array}$ & \\
\hline & Laiks & $\begin{array}{l}\text { Korel koef } \\
\text { P } \\
\text { N }\end{array}$ & $\begin{array}{c}0,229 \\
0,412 \\
15\end{array}$ & $\begin{array}{c}-0,247 \\
0,438 \\
12\end{array}$ & $\begin{array}{c}0,204 \\
0,466 \\
15\end{array}$ & 15 \\
\hline
\end{tabular}

Veicot parametrisko Pīrsona korelāciju ar ksenogēno un sintētisko materiālu grupām pēc laika, kāds pagājis kopš ADPP, tika konstatētas negatīvas korelācijas sintētisko materiālu grupā visās augmentētās zonas mērījumu vietās, bet ksenogēno 
materiālu grupā tikai BAZ punktā (6.21. tabula). Allogēno materiālu grupa statistskāa analīzē netika iekḷauta nelielās grupas dēḷ.

6.21. tabula

Korelācija augmentētās zonas nomelnējuma līmeņa attiecībā pret pagājušo laiku starp dažādu biomateriālu grupām

\begin{tabular}{|c|c|c|c|c|c|c|}
\hline \multicolumn{3}{|c|}{ Biomateriālu grupa } & \multirow{2}{*}{$\begin{array}{c}\text { BAZ } \\
1 \\
24\end{array}$} & \multirow[t]{2}{*}{$\mathbf{A P}$} & \multirow[t]{2}{*}{ PAZ } & \multirow[t]{2}{*}{ Laiks } \\
\hline $\begin{array}{l}\text { Sintētiskie } \\
\text { materiāli }\end{array}$ & BAZ & $\begin{array}{l}\text { Pīrsona kor } \\
\text { P } \\
\text { N }\end{array}$ & & & & \\
\hline & $\mathrm{AP}$ & $\begin{array}{l}\text { Pīrsona kor } \\
\text { P } \\
\text { N }\end{array}$ & $\begin{array}{c}0,673 \\
0,001 \\
21\end{array}$ & $\begin{array}{c}1 \\
21 \\
21\end{array}$ & & \\
\hline & PAZ & $\begin{array}{l}\text { Pīrsona kor } \\
\text { P } \\
\text { N }\end{array}$ & $\begin{array}{c}0,497 \\
0,014 \\
24\end{array}$ & $\begin{array}{c}0,668 \\
0,001 \\
21\end{array}$ & $\begin{array}{c}1 \\
24\end{array}$ & \\
\hline & Laiks & $\begin{array}{l}\text { Pīrsona kor } \\
\text { P } \\
\text { N }\end{array}$ & $\begin{array}{c}-0,573 \\
0,003 \\
24\end{array}$ & $\begin{array}{c}-0,433 \\
0,050 \\
21\end{array}$ & $\begin{array}{c}-0,393 \\
0,058 \\
24\end{array}$ & $\begin{array}{c}1 \\
24\end{array}$ \\
\hline Ksenogēnie & BAZ & $\begin{array}{l}\text { Pīrsona kor } \\
\text { P } \\
\text { N }\end{array}$ & 33 & & & \\
\hline & $\mathrm{AP}$ & $\begin{array}{l}\text { Pīrsona kor } \\
\text { P } \\
\text { N }\end{array}$ & $\begin{array}{c}0,242 \\
0,175 \\
33\end{array}$ & 33 & & \\
\hline
\end{tabular}

6.21. tabulas turpinājums nākamajā lapā. 
6.21. tabulas turpinājums.

\begin{tabular}{|l|l|l|c|c|c|c|}
\hline \multicolumn{2}{|l|}{ Biomateriālu grupa } & BAZ & AP & PAZ & Laiks \\
\hline Ksenogēnie & PAZ & Pīrsona kor & 0,298 & 0,370 & 1 & \\
& & P & 0,092 & 0,034 & & \\
& & N & 33 & 33 & 33 & \\
\hline Ksenogēnie & Laiks & Pīrsona kor & $-0,407$ & 0,049 & $-0,149$ & 1 \\
& & P & 0,019 & 0,787 & 0,407 & \\
& & N & 33 & 33 & 33 & 33 \\
\hline
\end{tabular}




\section{DISKUSIJA}

Vidējās vecuma grupas pieaugušo pacientu mutes veselības stāvoklis ir pētīts daudzās Eiropas valstîs. Līdzīgā atrade visos pētījumos ir tā, ka indivīda sociāli ekonomiskais stāvoklis ir saistīts ar mutes un zobu veselības stāvokli. Jo augstāka pacienta labklājīiba un izglīî̄bas līmenis, jo labāka ir mutes higiēna, zobu stāvoklis un pacienta apmierinātība ar savu mutes dobumu gan funkcionālā, gan estêtiskā ziņā. Pētijumos norādīts, ka bērnībā iegūtās iemaņas un paradumi mutes veselības uzturēšanā, kā arī sociāli ekonomiskais stāvoklis gimenē ir nozīmīgs faktors mutes veselības stāvokḷa uzturēšanā visā dzīves gaitā. Valstīs ar augstāku dzīves standartu arī mutes veselības stāvoklis ir labāks visas dzīves garumā un pacienti biežāk ir apmierināti ar to (Shen, 2013; Listl, 2012; Singh, 2013; Tseveenjav, 2012; Kengne Talla, 2013). Latvijā zobārstniecība pieaugušajiem ir maksas pakalpojums. Jādomā, ka pētijumā iekḷautie pacienti reprezentē Latvijas ekonomiski nodrošināto un izglîtoto daļu. Šăda pacientu izpēte šī darba ietvaros netika veikta.

Promocijas pētījuma izpētes grupas demogrāfiskie dati uzrādīja, ka augšžokḷa dobuma pamatnes paaugstināšanas operācijas ar kaulu aizstājošu biomateriālu lietošanu biežāk tiek veiktas sieviešu dzimuma pacientēm. Mūsu pētījumā sieviešu dzimuma pārstāves vidēji bija nedaudz jaunākas par vīriešu dzimumu pārstāvošiem subjektiem. Šādi rezultāti neliecina, ka sievietēm ADPP operācijas ir vairāk nepieciešamas nekā vīriešiem. Drīzāk varētu domāt, ka sievietes vairāk rūpējas par sevi un tādēl biežāk piekrīt plašākām operatīvām manipulācijām. Par to liecina arī pêtījumi, kas veikti Latvijā, kur tika salīdzināts arī vīriešu un sieviešu mutes veselības stāvoklis pusmūža un vecākās grupas pacientiem. Pētījumos netika atrasta statistiski ticamas atšķirības starp abu dzimumu mutes dobumu stāvokḷiem (Vidzis, 2012; Vidzis, 2011). Pētījumi, kas veikti citās Eiropas valstīs apstiprina faktu, ka sievietes vairāk rūpējas par savu veselību (Tseveenjav, 2012; Kengne Tall, 2013; Pizarro, 2008). Arī augšžokḷa pušu sadalījums, kurās tika veiktas operācijas, bija praktiski vienāds. Kreisā puses ADPP tika veikts tikai par 2 gadījumiem biežāk nekā labās puses.

Kontroles grupā dzimumu sadalījums bija praktiski vienāds, un vidējais vecums bija tuvs pētījuma grupas vidējam vecumam. Kontroles grupā sieviešu vidējais vecums bija mazāks, bet vīriešu - lielāks, tomēr bez statistiski ticamas atšķirības starp dzimumiem. 
Pētîjuma grupas atlases kritērijs - vismaz gads pēc ADPP operācijas līdz atkārtotam KSDT izmeklējumam - tika izvēlēts, lai novērtētu operācijas rezultātus ilgtermiņā.

Pētījuma grupā veicot ADPP, tika pielietoti kaulu aizstājošie biomateriāli ar kalcija fosfātiem kā galveno strukturēto elementu. Tādi bija pieci dažādi materiāli, kurus varēja sadalīt trīs grupās, atkarībā no to izcelsmes: allogēnie, ksenogēnie un sintētiskie materiāli. Salīdzinot laiku pēc operācijas līdz atkārtotam KSDT izmeklējumam tika konstatēts, ka visilgākais laiks bija pagājis allogēno un sintētisko materiālu grupās, kamēr ksenogēnu materiālu grupā vidējais laiks bija apmēram par 6 mēnešiem īsāks. To varētu skaidrot ar ADPP veicošo ķirurgu individuālām zināšanām, uzskatiem un to interpretāciju, kā arī pacientu vēlmēm, ekonomiskiem apsvērumiem un citiem individuāliem faktoriem. Augšžokḷu dobumu pamatnes paaugstināšanas operācijas izvērtējumu histoloǵiskie un histomorfologiskie rezultāti, kas pieejami literatūrā, parasti aprobežojas ar pirmajiem 12 pēc operācijas mēnešiem (Zhang, 2012; Barone, 2013). Atkārtotas operācijas laikā, kad tiek veikta zobu implantātu ievietošana, parasti līdztekus tiek ņemts histologiiskais materiāls. Vēlāki histoloǵgiski pētījumi ir reti pieejami, jo nepieciešama atkārtota ķirurğiska iejaukšanās (Klein, 2013). Citi ilgtermiņa pētījumi visbiežāk ir implantāta klīniskā izvērtējuma (Cavalli, 2012) un radioloǵiskie pētījumi, kad atkārtota intervence augmentētajā zonā netiek veikta (Tetsch, 2010). Ilgtermiṇa pētījumi, kuros analizētas lielas pētījumu grupas, arī nav bieži publicēti, jo pastāv atlase kritēriju izpildes grūtības.

\subsection{Augšžokḷa dobuma radiologiiskās atrades}

Trīs dimensiju attēla diagnostika ir rekomendējošā metode augšžokḷa dobumu izvērtēšanā. Trīs dimensiju attēlos ir iespēja plašāk un precīzāk izvērtēt patolog̣ijas salīdzinājumā ar divu dimensiju, konvencionālām radiologijas diagnostikas metodēm (Nemec, 2009). Eiropas Deguna polipu un rinosinusīta primārās aprūpes un diagnostikas dokuments, ko izdevusi Eiropas alergolog̣ijas un klīniskās imunologijas akadēmija, norāda, ka radiologiskie izmeklējumi veicami tikai gadījumos, ja klīniskā atrade ir aizdomīga vai pielietotā terapija nav efektīga (Thomas, 2008). Arī šajā dokumentā norādīts, ka konvencionālās radiologijas metodes augšžokḷa dobuma vizualizēšanai nav efektīvas. 
Mūsu pētījumā tika lietota trīs dimensiju attēla diagnostika, precīzākā attēla diagnostikas metode augšžokḷa dobumu vizualizācijai. Radioloǵiski novērtējamās augšžokḷa dobuma izmaiņas pārsvarā bija saistītas ar Šneidera membrānas izmaiṇām. Augšžokḷa dobuma gḷotādas sabiezējums tika mērīts milimetros KSDT attēla koronārajos griezumos. Divdesmit astoņos dobumos gḷotādas sabiezējums netika konstatēts vispār. Sešpadsmit dobumos gḷotādas sabiezējums tika konstatēts no viena līdz trīs milimetru robežās. Var apgalvot, ka 44 dobumos, kas ir 56,4\%, gḷotādas sabiezējums bija normas robežās. Tas ir tādā gadījumā, ja pieņemam, ka līdz $3 \mathrm{~mm}$ sabiezēta gl̦otāda ir uzskatāma par normu. Literatūrā nav vienprātības attiecībā par to cik milimetru gḷotādas sabiezējums ir uzskatāms par normālu. Tas svārstās no 1 līdz 5 milimetriem. Tomēr biežāk literatūrā izskan un prakse rāda, ka gḷotādas sabiezējumam virs $4 \mathrm{~mm}$ par iemeslu ir patolog̣isks kairinājums. Šāda sabiezējuma gadījumā biežāk ir vērojamas izmaiṇas arī etmoidālās šūnās un ir traucēta fizioloǵiskās atveres funkcija. Līdzīgus gḷotādas sabiezējuma mērījumu rezultātus var atrast literatūrā. Pētījumā, kur par patologiisku uzskatīja sabiezējumu sākot no $2 \mathrm{~mm}$, tas tika konstatēts $60,62 \%$ pacientu (Shanbhag, 2013). Par biežāko radiologiiski nosakāmo augšžokḷa dobuma patolog̣iju literatūrā min tieši gḷotādas sabiezējumu (Ritter, 2011). Pētījumā, kur retrospektīvi tika apsekoti 500 pacientu, tātad 1000 augšžokḷa dobumu, pirms implantācijas operācijas augšžoklī, kā patologiski sabiezētas gḷotādas kritērijs tika noteikta $3 \mathrm{~mm}$ robeža. Par trīs milimetriem biezāka gḷotāda tika konstatēta $62,6 \%$ gadījumu (Lana, 2012). Mūsu pētījumā biežākā radiologiski nosakāmā patolog̣ija augšžokḷa dobumā bija gḷotādas sabiezējums, kas procentuāli daudz neatšķkiras no literatūrā pieejamiem līdzīgu pētījumu datiem. Varētu domāt, ka gḷotādas sabiezējums ir atkarīgs no smēķēěanas, gadalaika, periodonta stāvokḷa vai laika kopš zobu ekstrakcijas, tomēr Janners un līdzautori (Janner, 2011), šādu sakarību neatrada. Autori konstatēja statistiski nozīmīgi biezāku gḷotādu vīriešu dzimuma pacientiem un gadījumos, ja tuvumā esošiem zobiem tika konstatētas periapikālas izmaiņas. Arī pacientiem vecākiem par 60 gadiem ir biežāk sastopama sabiezēta gḷotāda ( $L u, 2012)$. Retrospektīvā radioloǵiskā pētījumā gḷotādas sabiezējums tika konstatēts $25,1 \%$ gadījumu, bet cistiski sabiezēta gḷotāda 5,75\% gadījumu (Gracco, 2012). Šeit tika konstatēta arī statistiski ticama atšķirība starp sieviešu un vīriešu pacientiem. Vīriešiem cistiski sabiezēta gḷotāda tika atrasta gandrīz divas reizes biežāk nekā sievietēm un biežāk radioloǵiskas izmaiņas augšžokḷa dobumos varēja novērot pacientiem vecumā no 40 līdz 60 gadiem. Pētījumā tika iekḷauti 258 pacientu. Mūsu pētījuma grupa bija 
mazāka, kas varētu skaidrot kādēl netika iegūtas statistiski ticama atškşirība starp dzimumiem. Pēc operācijas radioloǵiskos izmeklējumos glotādas sabiezējums bija līdzīgs ar pirms operācijas konstatēto, kas varētu liecināt par to, ka ADPP operācija ilgtermiņā neietekmē augšžokḷa dobuma stāvokli. Pēc operācijas vienam pacientam tika konstatēts totāli aizēnots dobums, kas ir akūta sinusīta radiologiiskā pazīme, bet tam var būt arī cita izcelsme, piemēram, mukocēle, kas pilnībā aizņem augšžokḷa dobumu. Līdz ar to šajā gadījumā būtu jāizvērtē etiologijas faktors dobuma aizēnojumam. Pilnībā aizēnots dobums var būt redzams arī Šneidera membrānas perforācijas gadījumā, bet tad simptomi būtu vērojami uzreiz pēc operācijas. Biežāk akūtas pēcoperācijas izmaiņas ir Šneidera membrānas pietūkums, kas ir pārejoša parādība un izzūd drīz pēc operācijas. Pētījumi rāda, ka šis pietūkums izzūd vienas līdz četru nedẹlu laikā pēc ADPP, pielietojot kaulu aizvietojošus biomateriālus, un pietūkums skar visu dobuma membrānu, ne tikai operācijas vietu (Quirynen, 2012). Statistiski biežāk augšžokḷa dobuma iekaisumu, arī vēlīnu, konstatē gadījumos, ja pacientam pirms operācijas radiologiiski bijis vērojams augšžokḷa dobuma iekaisums vai sabiezēta gḷotāda (Manor, 2010). Dobuma gḷotādas sabiezējumu biežāk arī novēro pacientiem, kuriem ir astma (Tezer, 2006).

Pētot ortodontijas pacientu trīs dimensiju attēlus Pazer un līdzautori (Pazer, 2011) konstatēja, ka visbiežākā asimptomātiskāa un nejaušā radiologiskā atrade augšžokḷa dobumā ir bazāli sabiezēta glotāda. Viṇu pētījumā tie bija 23,7\% gadījumos. Tikmēr cistiski sabiezētas gl̦otādas atrade tika konstatēta 19,4\% gadījumu. Tā kā šajā pêtījumā tika analizēti ortodontijas pacientu radiologiskie izmeklējumi, tad tas varētu būt iemesls nelielām atšķirībām ar mūsu pētījuma rezultātiem. Minētā pētîjumā netika atrastas statistiski ticamas saistības pēc gadalaika, kad radioloǵiskais izmeklējums veikts (Pazer, 2011).

Gḷotādas sabiezējuma tips promocijas darba pētījumā tika noteikts, jo dažādu tipu gadījumā ietekme uz dobuma fiziologiiskās atveres funkcionalitāti var būt atšksirīga (Carmeli, 2011). Pētījuma autori norāda, ka augšžokḷa dobuma atveres obstrukcija biežāk ir novērojama cirkulāri, neregulāri un pilnībā aizēnoto dobumu gadījumos. Mūsu pētījumā cirkulāri, neregulāri sabiezētas gḷotādas un pilnībā aizēnoti dobumi bija reta atrade, un preoperatīvajos radioloǵiskajos izmeklējumos dobuma obstrukcija bazāli sabiezētas gḷotādas gadījumā bija vērojama biežāk nekā cirkulāri sabiezētas gḷotādas gadījumā. Jāpiemin, ka preoperatīvi dobuma fiziologiskās atveres obstrukcija kopumā tika konstatēta tikai 9 dobumiem. Pēc operatīvos KSDT izmeklējumos atveres 
obstrukcija arī bija reta parādība. Obstrukcija tika konstatēta tikai 11 gadījumos. Postoperatīvajos KSDT izmeklējumos pieauga to obstrukciju skaits, kuras tika konstatētas pie cirkulāri sabiezētas gḷotādas un pilnībā aizēnotā dobuma. Gḷotādas sabiezējuma tips nebija atkarīgs no ADPP operācijas gaitā lietotā biomateriāla. Pēc operācijas izmeklējumos tika atklāta vāja korelācija starp gḷotādas sabiezējumu un augšžokḷa dobuma fiziologiskās atveres obstrukciju. Tas nozīmē - jo lielāks bija gḷotādas sabiezējums pēc operācijas izmeklējumos, jo biežāk tika konstatēta dobuma atveres obstrukcija. Abas pazīmes - atveres obstrukcija un gḷotādas sabiezējums, tiek uzskatītas par radiologiiskām hroniska rinosinusīta pazīmēm, kas liecina par iekaisuma procesu izmeklējuma brīdī. Izmeklējums tika veikts vismaz gadu pēc operācijas, kas tomēr norāda, ka iekaisuma procesam ir cits, piemēram, vīrusa izcelsmes, raksturs.

Promocijas pētījumā tika reǵistrētas arī papildu atveres esamība gan pirms operatīvos, gan pēc operācijas izmeklējumos. Papildu atvere tiek uzskatīta par pārciesta, hroniska iekaisuma sekām. Tā lokalizējas augšžokḷa dobuma mediālā sienā dorsāli no fiziologiiskās atveres un izveidojas skrimslī, kas veido anatomisku robežu starp deguna dobumu un deguna blakus dobumu. Atvere rodas dobuma iekaisuma reakcijas un dobuma spiediena rezultātā, bet tai nav nekādas funkcijas. Tā dobuma drenāžu neatvieglo. Mūsu pētījumā pēc operācijas izmeklējumos tika atrastas tieši tik pat papildus atveres kā pirms operācijas izmeklējumos. Tas, ka netika konstatētas jaunas papildus atveres vēlīnos izmeklējumos, liecina par to, ka laika posmā starp ADPP operāciju un atkārtoto KSDT izmeklējumu akūti un hroniski iekaisumu saasinājumi ar lielāko varbūtību nav notikuši. Tādējādi mēs pastarpināti varam izslēgt ADPP operāciju kā iekaisumu veicinošu faktoru augšžokḷa dobumā.

Deguna vidējās gliemežnīcas pneimatizāciju, sauktu par concha bullosa, uzskata par riska faktoru maksilārā dobuma iekaisuma patolog̣ijā. Lielas pneimatizētas gliemežnīcas var sašaurināt vai nosprostot dobuma atveri attiecīgi traucējot dobuma drenāžu (Farina, 2010). Savukārt pētot 1095 pacientu DT izmeklējumus retrospektīvi, netika konstatētas sakarības starp concha bullosa un maksilārā dobuma sinusīta radiologisko atradi. Tika konstatēta korelācija starp pneimatizēto gliemežnīcu un deguna starpsienas deviāciju pretējā virzienā (Stallman, 2004). Uzskata, ka dobumu izklājošā skropstiṇu epitēlija fizioloǵiskais kustīgums ir nozīmīgākais faktors sinusīta profilaksē. Anatomiskie varianti, tādi kā concha bullosa, netiek uzskatīti par predisponējošiem faktoriem (Tsai, 2012). Mūsu pētījumā pneimatizēto gliemežnīcu daudzums palielinājās pēc operāciju izmeklējumos. Subjektīvi pieauga arī to izmēri. 
Tika atrasta arī vāja negatīva korelācija starp concha bullosa atradi un gḷotādas biezumu milimetros, kas nozīmēe, ka pie concha bullosa atrades pēc operācijas izmeklējumos vērojama mazāk sabiezēta gḷotāda, kas ir pretrunā tam, ka gliemežnīcas pneimatizācija var kavēt dobuma drenāžu un sekmēt iekaisuma procesu tajā. Mūsu pētījuma atrade apstiprina, ka concha bullosa nav negatīvas ietekmes uz dobuma fizioloǵisko drenāžu un pneimatizēta vidējā deguna gliemežnīca nav augšžokḷa dobuma iekaisuma predisponējošs faktors.

Augšžokḷa dobuma tilpums tika mērīts gan preoperatīvos, gan pēc operācijas izmeklējumos. Tika atrastas statistiski ticamas atšķirības starp abiem mērījumiem. Pēc operācijas tilpuma samazinājums ir statistiski nozīmīgs. Mūsu pētījumā vidējais augšžokḷa dobuma tilpums pirms operācijas un pēc operācijas bija nedaudz atšķirīgs no literatūrā pieejamiem datiem, kur vidējais tilpums ir uzrādīts $15700 \pm 5300 \mathrm{~mm}^{3}$ (Sahlstrand - Johnson, 2011), tikmēr citā pētījumā (Deeb, 2011) dobumu tilpums bija $24100 \pm 9700 \mathrm{~mm}^{3}$. Atšksirība varēja rasties, jo tika izmantotas atšķirīgas tilpuma noteikšanas metodes. Meklējot literatūras avotus neizdevās atrast nevienu pētījumu, kurā augšžokḷa dobuma tilpumi būtu noteikti pirms un pēc pamatnes augmentācijas operācijas izmantojot Dolphin Imaging programmu. Bez tam mūsu pētījumā pacienti bija ar iztrūkstošiem zobiem, kuru vietā, iespējams bija ne tikai atrofējies alveolārais izaugums, bet arī pneimatizējies augšžokḷa dobums, tādā veidā palielinot dobuma tilpumu. Promocijas pētījumā netika konstatêtās atšķirības starp augšžokḷu dobumu tilpumiem starp sievietēm un vīriešiem. Jādomā, ka arī te par iemeslu varētu būt zobu zaudējums, atšķirīgie grupu vecumi un mērījuma noteikšanas metodes (Vidya, 2013). Kaut arī tilpuma atšķirība starp abiem mūsu mērījumiem ir statistiski nozīmīga, to vidējie rādītāji abos gadījumos ir tuvu norma. Tas liecina, ka augmentācijas operācijas rezultātā augšžokḷa dobuma tilpums būtiski netiek izmainīts, netiek izmainīta tā homeostāze.

\subsection{Alveolārā kaula un augšžokḷa dobuma pamatnes augmentētās zonas mērījumi}

Pirms operācijas radiologiskajos izmeklējumos tika noteiktas kaula dimensijas augmentācijai paredzētajā vietā. Netika konstatēta statistiski ticama atšksirība starp dzimumiem reziduālā kaula augstuma un platuma mērījumos. Mērot kaula radioloǵisko nomelnējuma līmeņa vērtību pirms operācijas vietā arī netika konstatētas statistiski 
ticamas atšķirības starp dzimumiem. Pētījuma grupā tika konstatēta statistiski ticama korelācija starp kaula augstumu un platumu, kas nozīmē, jo augstāks ir alveolārais kauls, jo tas arī ir platāks. Ir atklāts, ka zemāka reziduālā kaula gadījumos, biežāk novēro Šneidera membrānas perforāciju (Deepthi, 2012), skaidrojot to ar plānāku kaulu un mazākiem dobumiem. Mūsu pētījumā šādas sakarības netika konstatētas.

Negatīvā korelācija starp kaula augstumu un kaula radioloǵisko nomelnējuma līmeņa vērtību liecina, ka augstākam reziduālam kaulam ir zemāks nomelnējuma līmenis. Nomelnējuma līmeņa vērtība samazinās, jo mazāk tiek aizturēts starojums. Starojumu labāk aiztur blīvāki objekti. Augstākam reziduālajam alveolāram kaulam ir zemāks radiologiiskais nomelnējuma līmenis, kas pastarpināti liecina, ka šādam kaulam ir mazāks blīvums. Iespējams, ka reziduālā alveolārā kaula dimensijas ir saglabājušās lielākas, jo zobu ekstrakcija ir veikta salīdzinoši nesen. Tas arī izskaidrotu faktu, kādēl kaula blīvums, kas radiologiiski redzams, kā samazināts kaula nomelnējums, ir mazāks. Interesanti, ka korelējot nomelnējuma līmeni un kaula augstumu, negatīvā korelācija atkārtojās sievietēm, bet vīriešiem netika konstatēta. Savukārt, salīdzinot kaula pirms operācijas augstumu, platumu un nomelnējuma līmeni, ar operācijas laikā lietotajiem biomateriāliem, nekādas atšksirības netika konstatētas. Jādomā, ka ķirurgiem plānojot ADPP operāciju ir citi kaulu aizvietojošo materiālu izvēles priekšnosacījumi.

Literatūras dati liecina, ka ADPP ar kaulu aizvietojošu materiālu pielietošanu ir izvēles metode gadījumos, kad reziduālā alveolārā kaula augstums ir samazināts tā, ka tas nespēj nosegt implantāta garumu. Nenosegti implantāti augšžokḷa dobumā var izraisīt gḷotādas sabiezēšanos un arī iekaisīgus procesus dobumā (Jung, 2007). Atkarībā no kaula augstuma var izvēlēties zobu implantācijas veikšanu vienlaicīgi ar augšžokḷa augmentāciju vai arī implantāciju kā otru operāciju vidēji 6 mēnešus pēc augmentācijas. Dati norāda, ka veicot zobu implantāciju un augmentāciju arī pie izteikta kaula zuduma nemazinās implantāta oseointegrācija (Fenner, 2009). Autori norāda, ka izvēle par labu divu etapu operācijai, ja kaula augstums ir mazāks par $5 \mathrm{~mm}$, nav zinātniski pamatota. Turklāt atkārtotas, otras, operācijas veikšana palielina augšžokḷa dobuma iekaisuma risku (Manor, 2010). Neliels kaula reziduālais augstums nav ar kaulaudus aizvietojošu biomateriālu augmentētas zonas konsolidācijas un zobu implantātu oseointegrācijas riska faktors (Avila - Ortiz, 2012). No otras puses, sekmīgas zobu implantātu oseointegrācijas priekšnoteikums ir to primāra stabilitāte, ko nosaka ne tikai reziduālā alveolārā kaula augstums un platums, bet arī blīvums. 
Veicot lineāros mērījumus augmentētā zonā tika iegūta pozitīva korelācija starp augmentētās zonas platumu un garumu, kā arī platumu un augstumu. Korelējot augmentētās zonas parametrus ar pirms operācijas izmeklējumiem tika konstatēts, ka pie mazāka kaula augstuma tiek veidota augstāka un platāka augšžokḷa dobuma pamatnes paaugstināšanas zona. Ir saprotams, ka pie neliela kaula daudzuma, kad ir nepieciešams adekvāts materiāla daudzums, lai nosegtu un balstītu implantātu vertikālā dimensijā, ir nepieciešams arī adekvāts platums horizontālajā dimensijā. Tādejādi tiek palielināts kontakts ar esošo kaulu, kas uzlabo augmentētās zonas asins apgādi, nodrošinot šūnu migrāciju un stabila biomateriāla/ audu hibrīda veidošanos. Augmentētās zonas sagitālā dimensija, kas mērījumos redzama kā augmentētās zonas garums, ir atkarīga gan no augmentētās zonas augstuma un platuma, gan arī no plānoto zobu implantātu skaita. Līdzīgā pētījumā tika konstatēts, ka palielinoties augmentētās zonas augstumam pieaug arī augmentētās zonas tilpums (Krennmair, 2006), kas sakrīt ar mūsu pētījumā iegūtiem datiem. Tikai mēs nemērījām augmentêtās zonas tilpumu, bet gan tās platumu un garumu. Minētajā pētījumā tika konstatēts, ka palielinot augmentētās zonas augstumu par $5 \mathrm{~mm}$, zonas tilpums pieaug divas reizes.

Atsevišķi salīdzinot augmentētās zonas lineāros parametrus starp pētījumā lietotām biomateriālu grupām jāsecina, ka vislielākos konglomerātus radiologisiski varēja redzēt tieši ksenogēno materiālu grupā. Ksenogēno materiālu grupā bija iekḷauts tikai Bio-Oss, Geistlich Biomaterials, Šveice, materiāls. Literatūrā ir pieejami dati, kas norāda, ka Bio-Oss granulu rezorbcija notiek lēni vai netiek novērota vispār (Tadjoedin, 2003; Kim, 2009). Histoloǵiski izvērtējot augmentētās zonas audus pētījumā, kurā audi tika ņemti gan 6 mēnešus, gan 11 gadus pēc ADPP operācijas pielietojot Bio-Oss, tika secināts, ka, lai arī biomateriāla granulas ir labi integrētas jaunveidotā kaulā, to izmēra izmaiņas abos histologiskajos izmeklējumos nav novērojamas (Mordenfeld, 2010). Tas varētu būt par iemeslu vislielākajiem konstatētajiem kaula - hibrīda zonām salīdzinājumā ar citiem materiāliem. Ksenogēno materiālu grupai atkārtotais izmeklējums tika veikts salīdzinoši agrāk kā citām grupām, līdz ar to, ksenogēno materiālu grupa tika īsāku laiku pakḷauta iespējamai rezorbcijas, remodelācijas un augšžokḷa dobuma repneimatizācijas spiedienam. Nevar arī neatzīmēt, ka ķirurga individuālā operācijas taktika var būt ksenogēno augmentātu dimensiju papildus iemesls..

Sintētisko materiālu lietotajos ADPP gadījumos augmentācijas zonas visi lineārie parametri atšķīrās no ksenogēno materiālu grupas lineāriem parametriem. Jau 
minēts, ka ksenogēno grupas materiāli uzrāda biosaderību (Ramirez - Fernandez, 2013 (1)), bet rezorbcija un remodelācija ir vāja vai netiek novērota vispār. Tas varētu būt viens no iemesliem dimensiju atšķirībai. Sintētisko materiālu grupai tika dots ilgāks laiks integrācijai un rezorbcijai. Bez tam ir konstatēts, ka pirmajos sešos mēnešos norit sintētisko materiālu augmentētās zonas remodelācija un tās samazinājums līdz pat 20\% (Kuhl, 2013), ko var izskaidrot gan ar dzī̌sanas un remodelācijas procesiem, gan iniciālu biomateriālu rezorbciju.

\subsection{Kaula un augmentētās zonas radioloğiskā attēla nomelnējuma līmeņa vērtības mērījumi}

Radiologiskā attēla nomelnējuma līmeņa vērtība atspoguḷo audu vai materiāla spēju aizturēt radiolog̣iskā stara fotonus, mainīt to virzienu vai enerǵiju. Jo blīvāki audi vai materiāls, jo lielāka to spēja izmainīt rentgena stara īpašības. Radiologiskā attēlā tas redzams kā gaišāks attēls - aizēnojums. Savukārt mazāka blīvuma audi un materiāls attēla redzams kā tumšāks attēls - izgaismojums. Līdz ar to radiologiskā attēla nomelnējuma līmenis ir lielāks, ja vairāk rentgena fotoni ir aizturēti vai izmainīti, kas savukārt nozīmē, ka audiem vai materiālam ir lielāks blīvums. Radioloǵiskā blīvuma mērījumi daudzslāņu datora tomogrāfijā tiek veikti audu un veidojumu diagnostikai, arī kaula blīvuma noteikšanas nolūkā. Mērījumi tiek veikti Haunsfîlda vienības. KSDT metodika atšksiras no DSDT, arī blīvuma mērījumu rezultāti nedaudz atšşiras, tādēl mērījumus KSDT attēlos veic, nosakot radiologiskā nomelnējuma līmeņa vērtību, mērvienība VV (grey value density, angḷu val) (Arisan, 2012). Mūsu pētījumā radiologisiskā nomelnējuma līmeņa vērtību ap implantātu noteicām piecos punktos, lai varētu salīdzināt ADPP operācijas rezultātus starp dažādiem lietotiem materiāliem, to ietekmi uz reziduālo kaulu, kā arī izmaiņas laika gaitā, nosakot kaula radioloǵisko izmaiņu dinamiku attiecībā pret implantētiem biomateriāliem. Tādējādi tika konstatēts, ka sintētisko un ksenogēno materiālu un kaula hibrīdi augmentētā zonā uzrāda augstāku radiologisko nomelnējuma līmeni salīdzinājumā ar allogēnajiem materiāliem. Salīdzinājumam veicām sterilu, iepakojumā esošu biomateriālu KSDT izmeklējumu un noteicām to radioloǵiskā nomelnējuma līmeṇa vērtības. Vislielāko radioloǵisko nomelnējuma līmeni uzrādīja RTU sintētiskās hidroksiapatīta granulas porozitāti 40-50\% ar poru lielumu ap $200 \mu \mathrm{m}$, kurām ar ievērojamu atšķirību sekoja pārējie 
materiāli. Ksenogēnais Bio-Oss uzrādīja otro mazāko radiolog̣iskā nomelnējuma līmeņa vērtību, kas bija mazāka arī par ūdens nomelnējuma vērtību. Lai izslēgtu iepakojuma un materiālā daudzuma ietekmi uz mērījuma rezultātiem, tika veikts atkārtots visu biomateriālu KSDT radiologiskais izmeklējums, šoreiz visus biomateriālus ievietojot identiskos traukos, identiskā daudzumā. Bio-Oss bija nepieciešams mazāks daudzums, arī masas ziṇā, lai aizpildītu trauku salīdzinājumā ar Straumann BoneCeramics un RTU sintētisko hidroksiapatītu. Gan Straumann Bone Ceramics, gan RTU sintētiskā hidroksiapatīta radiologiskā nomelnējuma vērtība pie atkārtotā izmeklējuma bija līdzịga iepriekšējiem rezultātiem. Bio-Oss gadījumā nomelnējuma vērtība vēl vairāk pazeminājās uzrādot - 400 VV. Vērtības samazinājumu atkārtotā izmeklējumā, kā arī nelielo nomelnējuma vērtību pirmajā izmeklējumā mēs skaidrojam ar vairākiem faktoriem. Tas, ka bija nepieciešams mazāks Bio-Oss materiāla daudzums, norāda, ka Bio-Oss granulas in vitro nepieguḷ viena otrai blīvi. To varētu ietekmēt granulu forma, kas ir neregulāra, veidojot daudz savstarpēji brīvu vietu. Tas ir vērojams arī mikroskopiskos materiālu attēlos (7.1. attēls), kur ar 2,5 palielinājumu uzrada granulu makroporozitāti un virsmas nelīdzenumus.

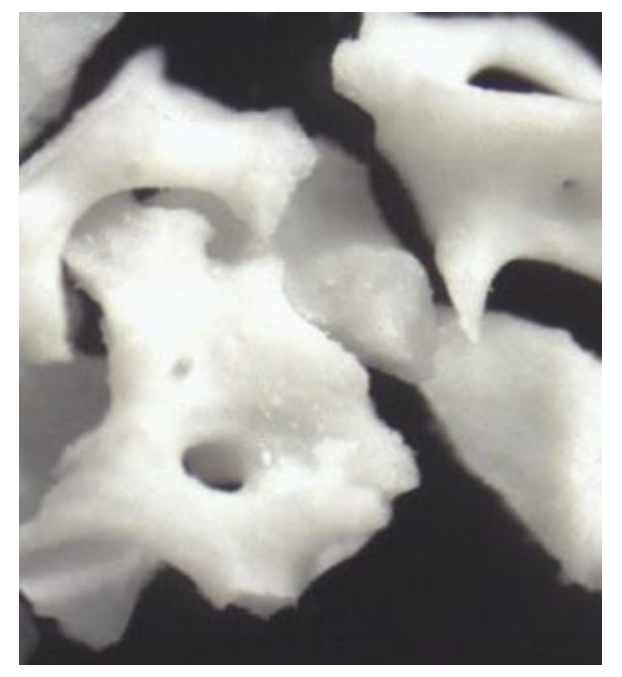

7. 1. att. Bio-Oss granulu mikroskopiskais attēls (bictel.ulg.ac.be)

Skenējošās elektronmikroskopijas attēlā redz granulu virsmas mikroporas (7.2. attēls). 

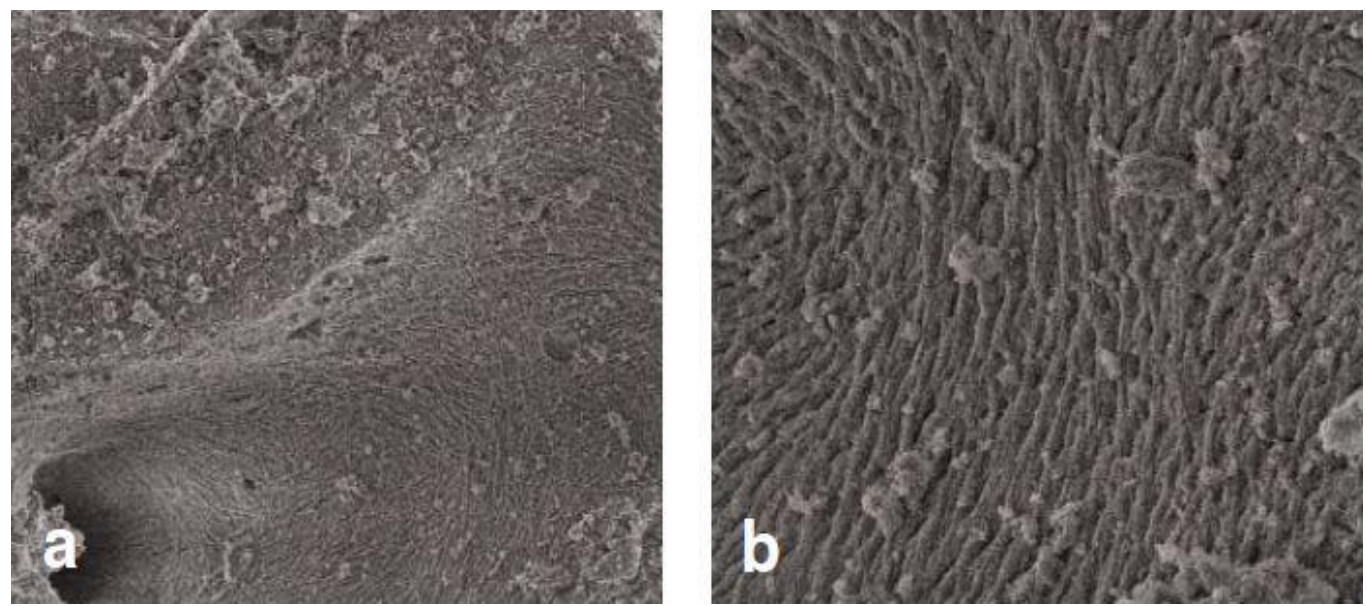

\section{2. att. Bio-Oss granulu skenējošās elektronmikraskopijas attēls a) 500 reižu} palielinājums; b) 2000 reižu palielinājums (bictel.ulg.ac.be)

Bio-Oss granulām ir neregulārā struktūra ar daudz sīku iekšēju kanāliṇu kā jau dabīgam trabekulāram kaulam. Bio-Oss tīrā materiāla in vitro ir daudz gaisa, gan starp granulām, gan granulu iekšienē, jādomā, ka atrodoties ilgu laiku oriǵinālā iepakojumā granulas bija novietojušās kompaktāk. Tas izskaidro šī materiāla nelielo radiologisko nomelnējuma līmeņa vērtību, kas tomēr oriǵinālā iepakojumā ar lielāku masu bija lielāks. Pēc operācijas izmeklējumos granulu gaisa pildītos kanālus un brīvo vietu starp granulām, aizpilda sākotnēji asinis, vēlāk saistaudi un kaulaudi. Bez tam mitrumā veidojas kompaktāka masa, kad granulas atrodas tuvāk viena otrai. Tādēḷ pēc operācijas nosakot biomateriāla/ audu hibrīda radioloǵisko nomelnējuma vērtību vērojama ievērojums radiolog̣iskā nomelnējuma līmeņa vērtības pieaugums.

Straumann BoneCeramic ir sintētisks biomateriāls. Mikroskopiskā attēlā redzams, ka tā granulas atrodas salīdzinoši tuvā kontaktā viena otrai, ir redzamas granulu makroporas un kristāliem līdzīgā struktūra (7.3. attēls). 


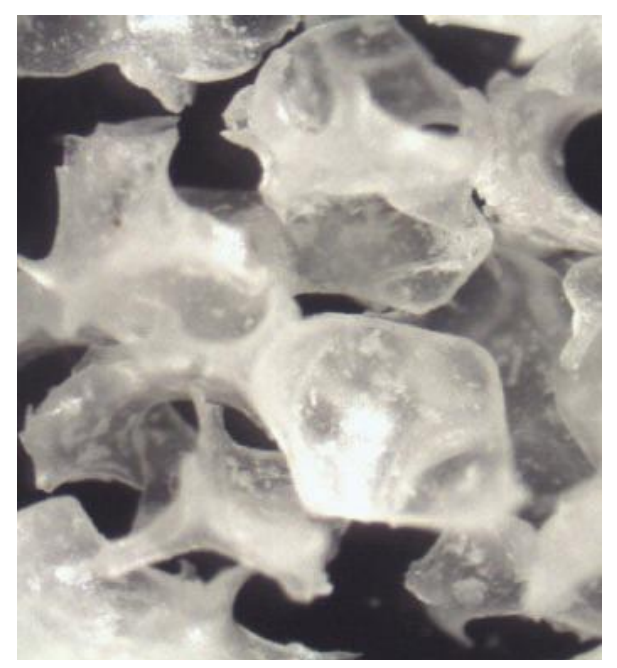

7.3. att. Straumann BoneCeramic granulu attēls (bictel.ulg.ac.be)

Skenējošā elektronmikroskopijas attēlā redzams, ka Straumann BoneCeramics materiāla granulu virsma ir gluda, bez mikroporām (7.4. attēls).
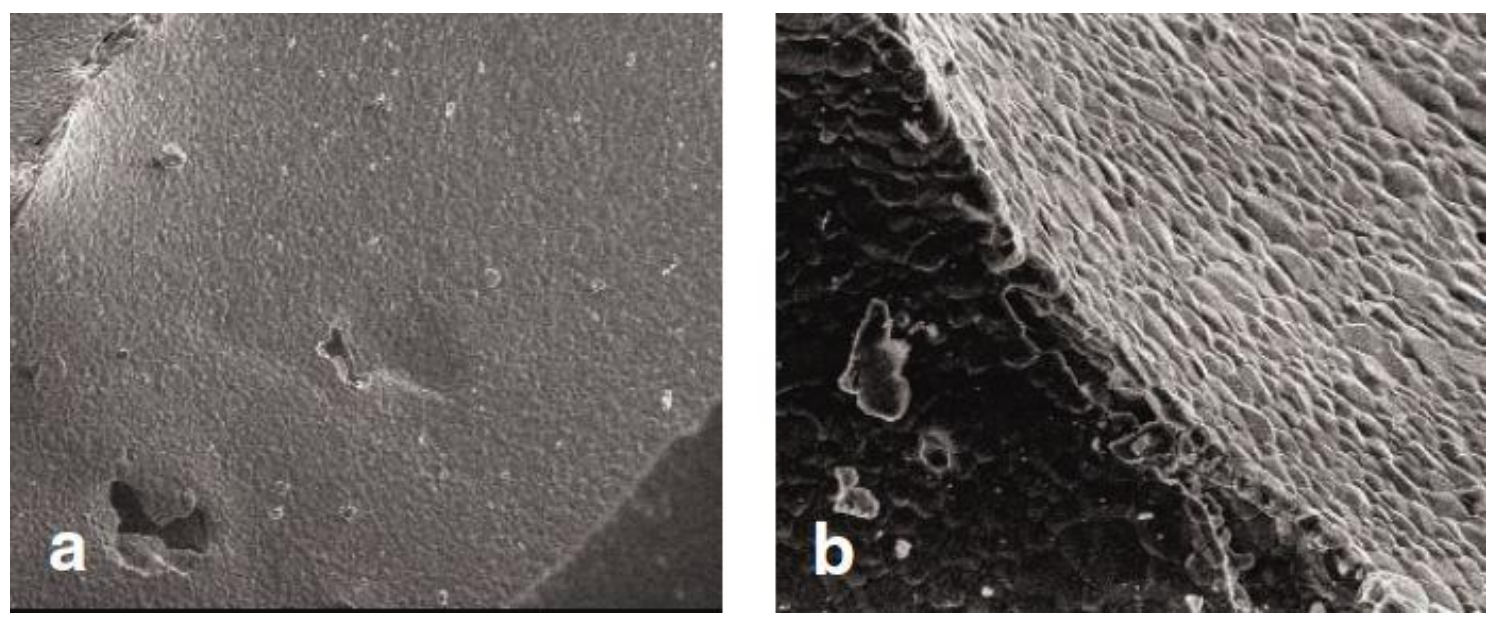

7.4. att. Straumann BoneCeramic granulu skenējošās elektronmikroskopijas attēls a) 500 reižu palielinājums; b) 2000 reižu palielinājums (bictel.ulg.ac.be)

Hidroksiapatîts ir sintētisks biomateriāls, kura virsma tiek apstrādāta, lai radītu reljefu un iekšēju struktūru. Mikroskopiski tas redzams ar mazāku virsmas reljefu un iekšējām kanāla sistēmām salīdzinājumā ar Bio-Oss (7.5. attēls). 


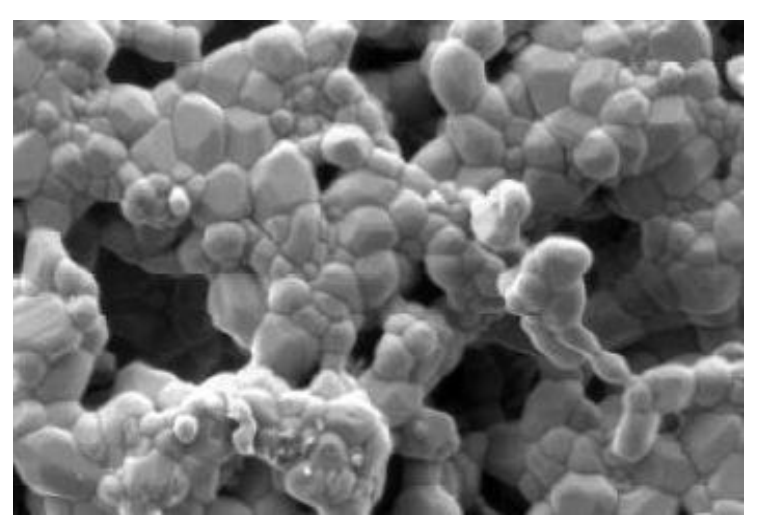

7.5. att. RTU Hidroksiapatīta granulu attēls (Salma, 2009)

Jādomā, ka biomateriālu radiolog̣iskā nomelnējuma līmeņa vērtība in vitro ir atkarīga no granulu formas, iekšējo un ārējo struktūru. Šāda biomateriālu izvērtēšana un salīdzināšana var būt tēma jaunam, atsevišksam pētījumam.

Pētījuma grupā, kurā netika ievietots zobu implantāts vienlaicīgi ar ADPP operāciju, kaula radiolog̣iskā nomelnējuma līmenis tika noteikts gan pirms, gan pēc operācijas. Pēc operācijas tika konstatēts reziduālā kaula nomelnējuma līmenim pieaugums vidēji par $200 \mathrm{VV}$, kas liecina par lielāku kaula spēju aizturēt rentgena staru. Tas pastarpināti liecina par pieaugušu reziduālā kaula blīvuma pieaugumu. Šādu pieaugumu var skaidrot ar reziduālā kaula mineralizācijas pieaugumu, kas notiek savstarpējā kaula - augmentētā biomateriāla mijiedarbības rezultātā. Šāda saistība tika konstatēta un apstiprināta ar Latvijas Republikas patentu LV14171 (B) (Skagers, 2010). Ilgstošu pētījumu rezultātā, kuros tika analizēts augšžokḷa atrofiskais kauls un tam pieguļošā augmentētā zona, tika secināts, ka vairāku gadu laikā minerālu blīvums biomateriālu zonā samazinās, toties pieaug atrofiskajā alveolārajā augšžokḷa kaulā. Līdzīgus secinājumus par kaula mineralizācijas pieaugumu un kalcija jonu difūziju gan reziduālā kaulā, gan jaunveidotā kaulā pēc histoloǵiskiem pētījumiem, ir izdarījuši arī citi autori (Kuhl, 2012; Ramirez - Fernandez, 2013 (1); Ramirez - Fernandez, 2013 (2)). Viņiem histoloǵiskajos pētījumos to izdevās pierādīt jau īsākā pēc operācijas laikā, attiecīgi pēc pieciem un deviņiem mēnešiem. Tātad jādomā, ka blīvuma vērtības pieaugums laika gaitā reziduālā kaulā mūsu pētījumā liecina par kaula mineralizācijas pieaugumu. Veicot līdzīgu pētījumu mazākai grupai tika iegūts analoǵisks secinājums (Neimane, 2012).

Rentgena staram starojot uz blīviem audiem un materiāliem, notiek tā nocietināšanās (beam hardening, angḷu val). Tas nozīmē, ka, staram izejot caur metālu, 
piemēram, implantātu, daḷa staru veidojošo fotonu, kuriem ir mazāka enerğija, tiek absorbēta un novirzīta (Schulze, 2011; Schulze, 2010). Veidojas artefakti, kas var izmainīt radioloğisko kaula nomelnējuma līmeņa mērījumus un arī kropḷo attēlu (7.6. attēls). Tā iemesla dēl, ka KSDT izmeklējumā attēls tiek veidots staram rotējot ap pacientu, artefakti var būt redzami visās dimensijās ap blīvo objektu.

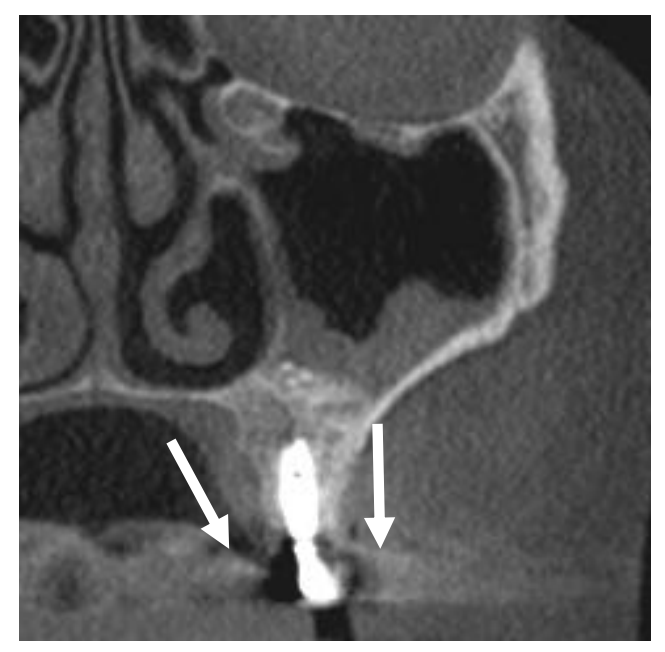

\section{6. att. KSDT koronārs griezums. Ar bultiṇām atzīmēti} stara nocietināšanās artefakti

Lai noteiktu, vai šādas izmaiņas notiek un cik liela ir to ietekme uz nomelnējuma līmeṇa vērtību, mēs atlasījām no datu bāzes kontroles grupu, kurā pacientiem zobu implantāts tika ievietots augšžokḷa alveolārā kaulā bez kaulu aizvietojošu materiālu lietošanas. Kontroles grupā, līdzīgi kā pētījuma grupā ar implantātu, mērījumi ap implantātu tika veikti 5 vietās. Radiologisiskā nomelnējuma vērtība pēc operācijas kontroles grupā visās mērījuma vietās pieauga salīdzinājumā ar mērījumu pirms operācijas. Lai aprēḳinātu implantāta radīto artefaktu un kaulu aizvietojošā biomateriāla patieso ietekmi uz reziduālo kaulu, tika salīdzinātas visas trīs grupas: kontroles grupa, pētījuma grupa ar implantātu un pētījuma grupa bez implantāta. Kontroles grupā kaulu mērījumu rezultāti abās pusēs koronārajā griezumā pie kaula malas bija pieaudzis par vidēji $700 \mathrm{VV}$ un tuvojās pêtījuma grupas ar implantātu rezultātiem. Te pieaugums bija konstatēts vidēji par 900 VV. Vismazākās izmaiņas bija vērojamas pētījuma grupā bez implantāta. Korelācijas analīze parādīja, ka implantāta klātbūtne ietekmē radioloǵiskā nomelnējuma līmeņa vērtību implantātam reziduālā kaula zonā gan bukāli, gan palatināli. Ir skaidrs, ka šādas sakarības cēlonis nevar būt 
implantātu fizioloǵiskā vai klīniskā ietekme uz apkārtējiem audiem. Visticamāk tās radušās attēla kroplojuma dēḷ, kādu izraisa rentgena stara izmaiņas un stara nocietināšanās. Lineārās regresijas rezultātā tika konstatēts, ka implantātu radīto artefaktu dēḷ, mērot reziduālā kaula radiologisiskā nomelnējuma līmeņa vērtību, no iekārtas uzrādītās vērtības bukālajā kaulā jāatṇem vidēji 800 VV (799, 492 VV), bet palatināli - vidēji $650 \mathrm{VV}(650,862 \mathrm{VV})$. Tātad, lai precīzi noteiktu reziduālā kaula nomelnējuma līmeņa vērtību no iekārtas uzrādītā rezultāta ir jāatņem iepriekšminētās vērtības, attiecīgi atsijājot implantāta un rentgena stara mijiedarbības rezultātā radušos attēla kropḷojumu un iegūstot patieso radiologiskā nomelnējuma līmeņa vērtību.

Tika atklāts, ka arī biomateriāli ietekmē reziduālā kaula radiologisiskā nomelnējuma līmeni bukāli no implantāta. Lineārā regresija uzrādīja, ka biomateriālu ietekmē bukālā reziduālā kaula malas radioloǵiskā nomelnējuma līmeņa vērtība pieaug par vidēji 300 VV (296,609 VV). Šādu kaula nomelnējuma līmeņa pieaugumu var radīt kaula mineralizācijas pieaugums, kas ir apstiprināts ar LR patentu. Iespēja, ka arī te pastāv artefaktu ietekme no biomateriāliem, ir neliela, ņemot vērā pašu materiālu nelielās nomelnējuma līmeņa vērtības un tas, ka netika novēroti pārliecinoši attēla kroplojumi. Literatūrā pieejamie dati apliecina reziduālā kaula mineralizācijas pieaugumu pēc ADPP operācijas ar kalcija fosfātu saturošiem materiāliem (De Lange, 2014; Ramirezs - Fernandez, 2013 (1); Kuhl, 2012). Nevar noliegt arī to, ka radiologiiskā nomelnējuma vērtību varētu ietekmēt ķirurga pieeja un operācijas pabeigšanas metodika. Pielietojot lielāku spēku un materiāla kondensāciju, varētu palielināt audu aizvietojošo materiālu blīvumu. Par šādu iespēju liecina arī fakts, ka palatināli kaula lineārās regresijas rezultātā netika konstatētas statistiski ticamas izmaiņas.

Kaula aizvietojošo materiālu nomelnējuma līmeņa vērtību mērījām arī augmentētajā zonā. Korelācijā pēc laika ilguma tika iegūta negatīva korelācija starp visām trīs mērījuma vietām augmentētā zonā. Tā tad augmentētajās zonas radiologiskāa nomelnējuma līmeņa vērtība, kas atkarīga no audu īstā blīvuma, mainās laika gaitā. Tas sakrīt ar daudziem pētījumiem, kur atzīmē pielietotā materiāla rezorbcija un aizvietošana ar kaulaudiem, saistaudiem (Handschek, 2009; Soardi, 2011; Wagner, 2012). Interesanti, ka salīdzinot korelāciju starp dzimumiem, vīriešiem tā netika konstatēta, kamēr sievietēm korelācijas stiprums pieauga.

Salīdzinot radiologískā nomelnējuma līmeņa vērtību starp sintētiskiem un ksenogēniem materiāliem, pēdējiem korelācija ar laiku netika atrasta. Ksenogēnos 
transplantātus mūsu pētījumā pārstāvēja Bio-Oss materiāls, kura granulu rezorbcija histoloǵiski ir vāji izteikta vai nenovēro vispār (Tadjoedin, 2003; Kim, 2009). To apstiprina arī mūsu radiologisko izmeklējuma rezultāti. Savukārt sintētisko materiālu grupā tika novērots radiologiiskā nomelnējuma līmeņa vērtības samazinājums laika gaitā. Jādomā, ka sintētisko materiālu rezorbcija laika gaitā notiek un ir nosakāma arī radiologiskos izmeklējumos. Sintētisko materiālu granulas rezorbējas un tiek aizstātas ar organisma audiem, kuriem ir samazināts blīvums. Remodelācija un jauna kaula veidošanās notiek aktīvāk sintētisko materiālu ADPP gadījumos (De Lange, 2014). 


\section{SECINĀJUMI}

1. Augšžokḷa dobuma pamatnes paaugstināšanas operācija ilgtermiṇā neietekmē augšžokḷa dobuma radioloǵiski nosakāmo funkcionalitāti un netiek izjaukta tā homeostāze.

2. Vidējās deguna gliemežnīcas pneimatizācija - concha bullosa, nav predisponējošs faktors augšžokļa dobuma iekaisuma patologiijā.

3. Augšžokḷa dobuma fiziologiiskās atveres obstrukcija biežāk novērojama, ja dobumā ir cirkulāri sabiezēta gḷotāda, pilnībā aizēnots dobums, kā arī, ja gḷotādas sabiezējums ir lielāks.

4. Augšžokḷa reziduālajam alveolārajam kaulam ar lielāku augstumu parasti ir arī lielāks platums ar mazāku radioloǵiskā nomelnējuma līmeņa vērtību.

5. Augšžokḷa reziduālā alveolārā kaula augstums ir noteicošs augmentētās zonas lieluma faktors. Pie mazāka alveolārā kaula augstuma, kāds vērojams pirms operācijas radiologiiskajos izmeklējumos, augšžokḷa dobuma pamatnes paaugstināšanas operācija tiek veikta dimensionāli lielāka. Tādai augmentētai zonai redz lielāku augstumu, platumu un garumu.

6. Vislielākie augmentētās zonas dimensiju parametri bija vērojami, ja operācijas laikā tika lietots ksenogēns materiāls.

7. Titāna zobu implantāts izmaina radioloǵisko KSDT attēlu rentgena stara nocietināšanas un atstarošanas artefaktu dēḷ. Artefaktu lielums reziduālajā palatinālajā kaulā ir $650 \mathrm{VV}$, reziduālajā bukālajā kaulā $-800 \mathrm{VV}$.

8. Kaulu aizvietojošie biomateriāli ilgtermiṇā ietekmē alveolārā kaula mineralizāciju. Kaula mineralizācija pieaug par 200-300 VV radiologisiskā nomelnējuma līmeņa vērtības vienībām.

9. Augmentētās zonas biomateriāla/ audu hibrīda radioloǵiskais nomelnējuma līmenis laika gaitā mazinās. 


\section{PRAKTISKĀS REKOMENDĀCIJAS}

1. Koniskā stara datora tomogrāfija ir izvēles radiologiiskā izmeklējuma metode augšžokḷa dobuma pamatnes paaugstināšanas operācijas plānošanā un ilgtermiṇa rezultātu izvērtēšanā.

2. Plānojot augšžokḷa dobuma pamatnes paaugstināšanas operāciju, radioloğiski jāizvērtē augšžokḷa reziduālā alveolārā kaula augstums un platums, lai varētu paredzēt nepieciešamā biomateriāla daudzumu.

3. Pirms operācijas jāizvērtē augšžokḷa dobuma stāvoklis. Sabiezēta gḷotāda, fiziologiiskās atveres obstrukcija, iekaisuma vai cita veida saslimšanas pazīmes uzskatāmas par pagaidu kontraindikācijām operācijas veikšanai.

4. Tā kā augšžokḷa dobuma pamatnes paaugstināšana pielietojot kaulu aizvietojošus biomateriālus, nepasliktina augšžokḷa dobuma stāvokli ilgtermiņā, tad nelabvēlīgas atrades gadījumā jāizvērtē citas saslimšanas vai komplikāciju iespēja. 


\section{IZMANTOTĀ LITERATŪRA}

1. Abrahams J.J., Berger S.B. Inflammatory disease of the jaws: appearence of reformated CT scans // AJR, 1998; 170: 1085-1091.

2. Abrahams J.J., Hayt M.W., Rock R. Sinus lift procedure of the maxilla in patients with inadequate bone for dental implants: radiographic appearance // AJR, 2000; 174: 1289-1292.

3. Alkan A., Celebi N., Bas B. Acute maxillary sinusitis associated with internal sinus lifting: report of the case // Eur J Dent, 2008; 2: 69-72.

4. Altman DG. Practical statistics for medical research // In: $7^{\text {th }}$ edition, Chapman \& Hall, London, Weinheim, New York, Melbourne, Madras. 1996: 122-326.

5. Anavi Y., Allon D.M., Avishai G. et al. Complications of maxillary sinus augmentations in a selective series of patients // Oral Surg Oral Med Oral Pathol Oral Radiol Endod, 2008; 106: 34-38.

6. Apostolakis D., Bissoon A.K. Radiographic evaluation of the superior alveolar canal: measurements of its diameter and of its position in relation to the maxillary sinus floor: a cone beam computerized tomography study // Clin Oral Impl Res, 2013; 00: 1-7. DOI: 10.1111/clr.12119

7. Aranyarachkul P., Caruso J., Gantes B. et al. Bone density assessments of dental implant sites: 2. Quantitative cone-beam computerized tomography // Int J Oral Maxillofac Implants, 2005; 20: 416-424.

8. Arai Y., Tammisalo E., Iwai K. et al. Development of compact computed tomographic apparatus for dental use // Dentomaxillofac Radiol, 1999; 28: $245-248$

9. Ardekian L., Oved-Peleg E., Mactei E.E. et al. The clinical significance of sinus membrane perforation during augmentation of the maxillary sinus // J Oral Maxillofac Surg, 2006; 64: 277-282.

10. Arisan V., Karabuda Z.C., Avsever H. et al. Conventional multi-slice computed tomography $(\mathrm{CT})$ and cone - beam CT (CBCT) for computer-assisted implant placement. Part I: Relationship of radiographic gray density and implant stability // Clin Impl Dent Rel Res, 2012; doi:10.1111/j.1708-8208.2011.00436.x 
11. Ashraf N., Bhattacharyya N. Determination of the "incidence" Lund score for the staging of chronic rhinosinusitis // J Otolaryngol Head Neck Surg, 2001; 125: 483-486.

12. Avery J.K. Oral development and histology // In: 3rd edition.Thieme, New York. 2002: 226-241.

13. Avila - Ortiz G., Neiva R., Galindo - Morena P. et al. Analysis of the influence of residual alveolar bone height on sinus augmentation outcomes // Clin Oral Impl Res, 2012; 23: 1082-1088.

14. Ayobian - Markazi N., Fourootan T., Kharazifar M.J. Comparison of cell viability and morphology of human osteoblast-like cell line (SaOC-2) seeded on various bone substitute materiāls: an in vitro study // Dent Res J, 2012; 9: 86-92.

15. Baciut M., Hedesiu M., Bran S. et al. Pre- and postoperative assessment of sinus grafting procedures using cone-beam computed tomography compared with panoramic radiographs // Clin Oral Impl Res, 2013; 24: 512-516.

16. Bagheri S.C, Bell R.B, Khan H.A. Current theraphy in oral and maxillofacial surgery // In: 1st edition, Elsevier Saunders, Missouri, 2012: 31-62.

17. Baig M.R, Rajan M. Effects of smoking on the outcome of implant treatment: a literature review // Indian J Dent Res, 2007; 18: 190-195.

18. Barone A., Ricci M., Grassi R.F. et al. A 6 - month histological analysis on maxillarys sinus augmentation with and without use of collagen membrane over the osteotomy window: randomized clinical trial // Clin Oral Impl Res, 2013; 24: doi:10.1111/j.1600-0501.2011.02340.x.

19. Barone A., Santini S., Sbordone L. et al. A clincial study of the outcomes and complications associated with maxillary sinus augmentation // Int J Oral Maxillofac Implants, 2006; 21: 81-85.

20. Bictel.ulg.ac.be. Lambert F. Influence of biomaterials in alveolar bone regeneration and preservation // www.bictel.ulg.ac.be/ETDdb/collection/available/ULgetd-05052011-133037/restricted/THESE.pdf., 2011

21. Block M.S., Kent J.N., Guerra L.R. Implants in Dentistry // In: WB Saunders, Philadelphia, 1997; 6-10.

22. Bornstein M.M., Cionca N., Mombelli A. Systhemic conditions and treatments as risks for implant therapy // Int J Oral Maxillofac Implants, 2009; 24: 12-27.

23. Brook I (1). Sinusitis of odontogenic origin // J Otolaryngol Head Neck Surg, 2006; 135: 349-355. 
24. Brook I (2). The role of anaerobic bacteria in sinusitis // Anaerobe, 2006; 12: $5-12$.

25. Browaeys H., Bouvry P., De Bruyn H. A literature review on biomaterials in sinus augmentation procedures // Clin Impl Dent Rel Res, 2007; 9: 166-177.

26. Bulman J.S., Osborn J.F. Statistics in dentistry // In: BDJ Books, London, UK, 2000: $1-70$.

27. Canullo L., Patacchia O., Sisti A. et al. Implant restoration 3 months after one stage sinus lift surgery in severely resorbed maxillae: 2 year results of a multicenter prospective clinical study // Clin Impl Dent Relat Res, 2012; 14: $412-420$.

28. Carmeli G., Artzi Z., Kozlovsky A. et al. Antral computerized tomography preoperative evaluation: relationship between mucosal thickening and maxillary sinus function // Clin Oral Impl Res, 2011; 22: 78-82.

29. Cassetta M., Stefanelli L.V., Pacifici A et al. How accurate is CBCT in measuring bone density? A comparative CBCT-CT in vitro study // Clin Implant Dent Relat Res, 2013; DOI 10.1111/cdi.12027.

30. Caudry S., Landzberg M. Lateral window sinus elevation technique: managing challenges and complications // J Can Dent Assoc, 2013; 79: d101.

31. Caughey R.J., Jameson M.J., Gross S.W. et al. Anatomic risk factors for sinus disease: fact or fiction? // Am J Rhinol Allergy, 2005; 19: 334-339.

32. Cavalli N., Barbaro B., Spasari D. et al. Tilted implants for full - arch rehabilitations in completely edentulous maxilla: a retrospective study // Int J Dent, 2012; doi:10.1155/2012/180379.

33. Cawood J.I., Howell R.A. A classification of the edentulous jaws // Int J Oral Maxillofac Surg, 1988; 17: 232-236.

34. Chipasco M., Zaniboni M., Rimondini L. Dental implants placed in grafted maxillary sinuses: a retrospective analysis of clinical outcome according to the initial clinical situation and a proposal of defect classification // Clin Oral Impl Res, 2008; 19: 416-428.

35. Clementini M., Ottaria L., Pandolfi C. et al. A novel technique to close large perforations of sinus membrane // Oral Implantol, 2013; 6: 11-14.

36. Cordaro L., Bosshardt D.D., Palattella P. et al. Maxillary sinus grafting with Bio-Oss or Straumann Bone Ceramic: histomorphometric results from a 
randomized controlled multicenter clinical trial // Clin Oral Impl Res, 2008; 19: 796-803.

37. Dager M.M., McNamara J.A., Baccetti T. et al. Aging in the craniofacial complex. Longitudinal dental arch changes through the sixth decade // Angle Orthodontist, 2008; 78: 440-444.

38. Dauber W. Pocket atlas of human anatomy // In: $5^{\text {th }}$ edition, Thieme, Stuttgart, Germany 2007: 236-239.

39. Deeb R., Malani P.N., Gill B. et al. Three - dimensional volumetric measurements and analysis of the maxillary sinus // Am J Rhinol Allergy, 2011; 25: $152-156$.

40. Deepthi B.C., Shetty S., Satish Babu C.L. et al. Correlation between gingival phenotype, residual ridge height and the Schneiderian membrane // Int J Oral Implantol Clin Res, 2012; 3: 111-115.

41. De Lange G.L., Overman J.R., Farre - Guasch E. et al. A histomorphometric and micro - computed tomography study of bone regeneration in the maxillary sinus comparing biphasic calcium phosphate and deproteinized cancellous bovine bone in a human split - mouth model // Oral Surg Oral Med Oral Pathol Oral Radiol, 2014; 117: 8-22.

42. De Vos W., Casselman J., Swennen G.R.J. Cone-beam computerized tomography (CBCT) imaging of the oral and maxillofacial region: a systhemic review of the literature // Int J Oral Maxillofac Surg, 2009; 38: 600-625.

43. Diz P., Scully C., Sanz M. Dental implants in the medically compromised patient // J Dent, 2013; 41: 195-206.

44. Donizeth-Rodrigues C., Fonseca-Da Silveira M., Goncalves-De Alencar A.H. et al. Three- dimentional images contribute to the diagnosis of mucous retention cyst in maxillary sinus // Med Oral Patol Oral Cir Bucal, 2013; 1: 151-157.

45. Du Tolt D.F., Nortje C. The maxillae: integrated and applied anatomy relevant to dentistry // SADJ, 2003; 58: 325-330.

46. Elian N., Wallace S., Cho S.C. et al. Distribution of the maxillary artery as it relates to sinus floor augmentation // Int J Oral Maxillofac Implants, 2005; 20: 784-787. 
47. Ella B., Sedarat C., Da Costa Noble R. et al. Vascular connetion of the lateral wall of the sinus: surgical effect in sinus augmentation // Int J Oral Maxillofac Implants, 2008; 23: 1047-1052.

48. European Commission. Radiation Protection No. 172. Cone beam CT for dental and maxillofacial radiology. Evidence based guidelines // In: Directorate General for Energy, Directorate D - Nuclear Energy, Unit D4 - Radiation Protection 2012, 71-76.

49. Fanghanel J., Proff P., Dietze S. et al. The morphological and clinical relevance of mandiblar and maxillary bone structures for implantation // Folia Morphol, 2006; 65: 49-53.

50. Farina D., Ravanelli M., Borghesi A. et al. Flying through congested airspaces: imaging of chronic rhinosinusitis // Insights imaging, 2010; 1: 155-160.

51. Feldkamp L.A., Davis L.C., Kress J.W. Practical cone-beam algorithm // J Opt Soc Am, 1984; 1: 612-619.

52. Feldmann H. The maxillary sinus and its illness in the history of rhinology. Images from the history of otorhinolaryngology, highlighted by instruments from the collection of the German Medical History Museum in Ingolstadt // Laryngorhinootologie, 1998; 77: 587-595.

53. Fenner M., Vairaktaris E., Fischer K. et al. Influence of residual alveolar bone height on osseointegration of implants in the maxilla: a pilot study // Clin Oral Impl Res, 2009; 20: 555-559.

54. Fugazzotto P.A., Vlassis J. A simplified classification and repair system for sinus membrane perforation // J Periodontol, 2003; 74:1534-1541.

55. Garbacea A., Lozada J.L., Church C.A. et al. The incidence of sinus membrane perforation during endoscopically assessed crestal sinus floor elevation: a pilot study // J Oral Implantol, 2012; 38: 343-359.

56. Gosau M., Rink D., Driemel O. et al. Maxillary sinus anatomy: a cadaveric study with clinical implications // Anat Rec, 2009; 292: 352-354.

57. Gracco A., Parenti S.I., Ioele C. et al. Prevalence of incidental maxillary sinus findings in Italian orthodontic patients: a retrospective cone - beam computed tomography study // Korean J Orthod, 2012; 42: 329-334.

58. Hallman M., Sennerby L., Zetterqvist L. et al. A 3-year prospective follow-up study of implant-supported fixed prostheses in patients subjected to maxillary 
sinus augmentation with 80:20 mixture of deproteinized bovine bone and autogenous bone. Clinical, radiographic and resonance frequency analysis // Int J Oral Maxillofac Surg, 2005; 34: 273-280.

59. Handschel J., Simonowska M., Naujoks C. et al. A histomorphometric metaanalysis of sinus elevation with various grafting materials // Head Face Med, 2009; 5: 12-22.

60. Harnsberger H.R., Glastonbury C.M., Michel M.A. et al. Diagnostic imaging. Head and neck // In: 2nd edition. Altona, Amirsys; 2011: IV-1: 28-44.

61. Hauman C.H.J., Chandler N.P., Tong D.C. Endodontic implications of the maxillary sinus: a review // International Endodontic Journal, 2002; 35: $127-141$.

62. Heinemann F., Mundt T., Biffar R. et al. A 3 year clinical and radiolographic study of implants placed simultaneously with maxillary sinus floor augmentations using nanocrystaline hydroxyapatite // J Physiol Pharmacol, 2009; 60: 91-97.

63. Hernandez - Alfaro F., Torradelflot M.M., Matri C. Prevalence and management of Scneiderian membrane perforations during sinus - lift procedures. Clin Oral Impl Res // 2008; 19: 91-98.

64. Herzberg R., Dolev E., Schwartz - Arad D. Implant marginal bone loss in maxillary sinus grafts // Int J Oral Maxillofac Implants, 2006; 21: 103-110.

65. Hodez C., Griffaton - Taillandier C., Benisimon I. Cone-beam imaging: applications in ENT // European Annals of Otorhinolaryngology, Head and Neck diseases, 2011; 128: 65-78.

66. Horwich P.J. Adrenal adenoma imaging // emedicine.medscape.com/article/ 376240. 2011.05.25.

67. Janner S.F.M, Caversaccio M.D, Dubach P. et al. Characteristics and dimensions of the Schneiderian membrane: a radiographic analysis using cone beam computed tomography in patients referred for dental implant surgery in the posterior maxilla // Clin Oral Impl Res, 2011; 22: 1446-1453.

68. Jensen O.T., Sennerby L. Histologic analysis of clinically retrieved titanium microimplants placed in conjunction with maxillary sinus floor augmentation // Int J Oral Maxillofac Implants, 1998; 13: 513-521.

69. Jensen S.S., Bornstein M.M., Dard M. et al. Comparative study of biphasic calcium phosphate with different HA/TCP ratios in mandibular bone defects. A 
long term histomorphometric study in minipigs // J Biomed Mater Res, 2009; 90: $171-181$.

70. Jensen S.S., Broggini N., Hjorting - Hansen E. et al. Bone healing and graft resorption of autograft, anorganic bovine bone and $\beta$-tricalcium phosphate. A histologic and histomorphometric study in the mandible of minipigs // Clin Oral Impl Res, 2006; 17: 237-243.

71. Johansson B., Grepe A., Wannfors K. et al. Volumetry of simulated bone grafts in the edentulous maxilla by computed tomography: an experimental study // Dentomaxillofac Radiol, 2001; 30: 153-156.

72. Jun B.C., Song S.W., Park C.S. et al. The analysis of maxillary sinus aeration according to aging process; volume assessment by 3 dimentional reconstruction by high-resolutional CT scanning // Otolaryngol Head Neck Surg, 2005; 132: 429-434.

73. Jung J.H., Choi B.H., Jeong S.M. et al. A retrospective study of the effects on sinus complications of exposing dental implants to the maxillary sinus cavity // Oral Surg Oral Med Oral Pathol Oral Radiol Endod, 2007; 103: 623-625.

74. Kan J.Y.K., Rungcharassaeng K., Lozada J.L. et al. Effects of smoking on implant success in grafted maxillary sinuses // J Prosthet Dent, 1999; 82: $307-311$.

75. Kau C.H., Bozic M., English J. et al. Cone-beam computed tomography of the maxillofacial region-an update // Int J Med Robot, 2009; 5: 366-380.

76. Kengle Talla P., Gagnon M.P., Dramaix M. et al. Barrier to dental visits in Belgium: a secondary analysis of the 2004 National Health Interview Survey // J Public Health Dent, 2013; 73: 32-40.

77. Kim M.J., Jung U.W., Kim C.S. et al. Maxillary sinus septa: prevalence, height, location and morphology. A reformatted computed tomography scans analysis // J Periodontol, 2006; 77: 903-908.

78. Kim Y.K., Yun P.Y., Kim S.G. et al.. Evaluation of sinus bone resorption and marginal bone loss after sinus bone grafting and implant placement // Oral Surg Oral Med Oral Pathol Oral Radiol Endod, 2009; 107: 21-28.

79. Kirmeier R., Payer M., Wehrschuetz M. et al. Evaluation of three-dimentional changes after sinus floor augmentation with different grafting materials // Clin Oral Impl Res, 2008; 19: 366-372. 
80. Klein M.O., Kammerer P.W., Gotz H. et al. Long-term bony integration and resorption kinetics of a xenogenic bone substitute after sinus floor augmentation: histomorphometric analyses of human biopsy specimens // Int J Periodontics Restorative Dent, 2013; 33: 101-110.

81. Klijn R.J., Van Den Beucken J.J.J.P., Bronkhorst E.M. et al. Predictive value of ridge dimensions on autologous bone graft resorption in staged maxillary sinus augmentation surgery using cone beam CT // Clin Oral Impl Res, 2012; 23: 409-415.

82. Kloss F.R., Gassner R. Bone and aging: effects on the maxillofacial skeleton // Experimental Gerantology, 2006; 41: 123-129.

83. Kolerman R., Goshen G., Joseph N. et al. Histomorphometric of maxillary sinus augmentation using an alloplast bone substitute // J Oral Maxillofac Surg, 2012; 70: $1835-1843$.

84. Koymen R., Gocmen-Mas N., Karacayli U. et al. Anatomic evaluation of maxillary sinus septa: surgery and radiology // Clinical Anatomy, 2009; 22: $563-70$.

85. Krennmair G., Krainhofner M., Maier H. et al. Computerized tomography assisted calculation os sinus augmentation voulume // Int J Oral Maxillofac Implants, 2006; 21: 907-913.

86. Kuhl S., Payer M., Kirmeier R. et al. The influence of particulated autogenous bone on early volume stability of maxillary sinus grafts with biphasic calcium phosphate: a randomized clinicl trial // Clin Implant Dent Relat Res, 2013: doi:10.1111/cid.12086.

87. Kuhl S., Gotz H., Brochhausen C. et al. The influence of substitute materials on bone density after maxillary sinus augmentation: a microcomputed tomography study // Int J Oral Maxillofac Implants, 2012; 27: 1541-1546.

88. Kumar H., Choudhry R., Kakar S. Accessory maxillary ostia: topography and clinical application // J Anat India, 2001; 50: 3-5.

89. Lambert F., Leonard A., Drion P. et al. Influence of space-filling materials in subantral bone augmentation: blood clot vs. autogenous bone chips vs. bovine hydroxyapatite // Clin Oral Impl Res, 2011; 22: 538-545.

90. Lana J.P., Carneiro P.M.R., Machado V.C. et al. Anatomic variations and lesions of the maxillary sinus detected in cone beam computed tomography for dental implants // Clin Oral Impl Res, 2012; 23: 1398-1403. 
91. Lang J. Clinical Anatomy of the Masticatory Apparatus Peripharyngeal Spaces // In: 1st edition. Thieme, New York. 1995: 16-18.

92. Lawson W., Patel Z.M., Lin F.Y. The development and pathologic processes that influence maxillary sinus pneumatization // Anat Rec, 2008; 291: 1554-1563.

93. Lee S., Gantes B., Riggs M. et al. Bone density assessments of dental implant sites: 3. Bone quality evaluation during osteotomy and implant placement // Int J Oral Maxillofac Implants, 2007; 22: 208-212.

94. Lindgren C., Mordenfeld A., Hallman M. A prospective 1 year clinical and radiographic study of implants placed after maxillary sinus floor augmentation with synthetic biphasic calcium phosphate or deproteinized bovine bone // Clin Impl Dent Rel Res, 2012; 14: 41-50.

95. Listl S. Inequalities in dental attendance throughout the life - course // J Dent Res, 2012; 91: 91-97.

96. Lu Y., Liu Z., Zhang L. et al. Wang H, Huang D. Associations between maxillary sinus mucosal thickening and apical periodontitis using cone - beam computed tomography scanning: a retrospective study // J Endod, 2012; 38: 1069-1074.

97. Lund V.J, Kennedy D.W. Staging of rhinosinusitis // J Otolaryngol Head Neck Surg, 1997; 117: 35-40.

98. Lund V.J., Mackay I.S. Staging in rhinosinusitis // Rhinology, 1993; 31: $183-184$.

99. Lundberg J.O. Nitric oxide and the paranasal sinuses // Anat Rec, 2008; 291: $1479-1484$.

100. Lundgren S., Andersson S., Gualini F. et al. Bone reformation with sinus membrane elevation: a new surgical technique for maxillary sinus floor augmentation // Clin Implant Dent Relat Res, 2004; 6: 165-173.

101. Maestre - Ferrin L, Galan - Gil S, Rubio - Serrano M, Penarrocha - Diago M, Penarrocha - Oltra D. Maxillary sinus septa: a systhemic review // Med Oral Patol Oral Cir Bucal, 2010; 3: 383-386.

102. Maestre - Ferrin L, Carrillo - Garcia C, Galan - Gil S, Penarrocha - Diago M, Penarrocha - Diago M. Prevalence, locations and size of maxillary sinus septa: panoramic radiography versus computed tomography scan // J Oral Maxillofac Surg, 2011; 69: 507-511. 
103. Malkinson S., Irinakis T. The influence of interfering septa on the incidence of Schneiderian membrane perforations during maxillary sinus elevation surgery: a retrospective study of 52 consecutive lateral window procedures // Oral Surgery, 2009; $2: 19-25$.

104. Manor Y., Mardinger O., Bietlitum I. et al. Late signs and symptoms of maxillary sinusitis after sinus augmentation // Oral Surg Oral Med Oral Pathol Oral Radiol Endod, 2010; 110: 1-4.

105. Marquez S. The paranasal sinuses: The last frontier in craniofacial biology // Anat Rec, 2008; 261: 1350-1361.

106. Mehra P., Murad H. Maxillary sinus disease of odontogenic origin // Otolaryngol Clin N Am, 2004; 37: 347-364.

107. Merkx M.A.W., Maltha J.C., Stoelinga P.J.W. Assessment of the value of anorganic bone additives in sinus flor augmentation: a review of clinical reports // Int J Oral Maxillofac Surg, 2003; 32: 1-6.

108. Miracle A.C., Mukherji S.K. Cone beam CT of the head and neck, part 1: physical principles // AJNR Am J Neuroradiol, 2009; 30: 1088-1095.

109. Miron R.J., Zhang Y.F. Osteoinduction: a review of old concepts with new standarts // J Dent Res, 2012; 91: 736-744.

110. Misch C.E. The pharmacologic management of maxillary sinus elevation surgery // J Oral Implants, 1992; 18: 15-23.

111. Mladina R., Vukovic K., Poje G. The two holes syndrome // Am J Rhinol Allergy, 2009; 23: 602-604.

112. Mladina R., Skitarelic N., Casale M. Two holes syndrome (THS) is present in more than half of the postnasal drip patients? // Acta Oto-Laryngologica, 2010; 130: $1247-1251$.

113. Moore K.L. The developing human. Clinically oriented embryology // In: 4th edition. Saunders, Philadelphia, 1988: 189-198.

114. Mordenfeld A., Hallman M., Johansson C.B. et al. Histological and histomorphometrical analysis of biopsies harvested 11 years after maxillary sinus floor augmentation with deproteinized bovine and autogenous bone // Clin Oral Impl Res, 2010; 21: 96-970.

115. Mossa - Basha M., Blitz A.M. Imaging of the paranasal sinuses // Seminars in Roentgenology, 2013; 42: 14-34. 
116. Mozzo P., Procacci C., Tacconi A et al. A new volumetric CT machine for dental imaging based on the cone-beam technique: preliminary results // Eur Radiol, 1998; 8: 1558-1564.

117. Nanci A. Ten Cate's oral histology: development, structure and function // In: 1st edition. Mosby Elsevier, Missuri, 2008: 51-56.

118. Neimane L., Skagers A., Slaidina A. Evaluation of edentulous maxillary alveolar bone with cone beam computed tomography (CBCT) in postmenopausal women // International Symposium of Biomedical Engineering and Medical Physics, IFMBE Proceeding, 2013; 38: 63-65.

119. Neimane L., Skagers A., Salms G. et al. Radiodensitometric analysis of maxillary sinus - lift areas enforced with bone substitute materials containing calcium phosphate // Acta Chirurgica Latviensis, 2012; 12: 41-44.

120. Nemec S.F., Peloschek P., Koelblinger C. et al. Sinonasal imaging after Caldwell - Luc surgery: MDCT findings of a abandoned procedure in times of functional endoscopy // Eur J Radiol, 2009; 70: 31-34.

121. Neugebauer J., Ritter L., Mischkowski R.A et al. Evaluation of maxillary sinus anatomy by cone--beam CT prior to sinus floor elevation // Int J Oral Maxillofac Implants, 2010; 25: 258265.

122. Nimigean V., Nimigean V.R., Maru $\mathrm{N}$ et al. The maxillary sinus floor in the oral implantology // Rom J Morphol Embryol, 2008; 49:485-489.

123. Nishimura T., Iizuka T. Evaluation of the pathophysiology of odontogenic maxillary sinusitis using bone scintigraphy // Int J Oral Maxillofac Surg, 2002; 31: 389-396.

124. Nkenke E., Stelzle F. Clinical outcome of sinus floor augmentation for implant placement using autogenous bone or bone substitutes: a systhematic review // Clin Oral Impl Res, 2009; 20: 124-133.

125. Nooh N. Effect of Schneiderinan membrane perforation on posterior maxillary implant survival // J Int Oral Health, 2013; 5: 28-34.

126. Nouraei S.A., Elisay A.R., Dimarco A. et al. Variations in paranasal sinus anatomy: implications for the pathophysiology of chronic rhinosinusitis and safety of endoscopic sinus surgery // J Otolaryngol Head Neck Surg, 2009; 38: $32-37$. 
127. Ozyuvaci H., Aktas I., Yerit K. et al. Radiological evaluation of sinus lift operation: what the general radiologist needs to know // Dentomaxillofac Radiology, 2005; 34, 199-204.

128. Pal U.S., Sharma N.K., Singh R.K. et al. Direct vs indirect sinus lift procedure: a comparison // Natl J Maxillofac Surg, 2012; 3: 31-37.

129. Pazera P., Bornstein M.M., Pazera A. et al. Incidental maxillary sinus findings in orthodontic patients: a radiographic analysis uzing cone-beam computed tomography (CBCT) // Orthod Cranifac Res, 2011; 14: 17-24.

130. Peleg M., Chaushu G., Mazor Z. et al. Radiological findings of the post-sinus lift maxillary sinus: a computerized tomography follow-up // J Periodontol, 1999; 70: 1564-1573.

131. Pieri F., Aldini N.N., Fini M. et al. Immediate fixed implant rehabilitation of the atrophic edentulous maxilla after bilateral sinus floor augmentation: a 12 month pilot study // Clin Implant Dent Relat Res, 2012, 14: 67-82.

132. Pietrokovski J., Starinsky R., Arensburg B. et al. Morphologic characteristics of bony edentulous jaws // J Prosthodont, 2007; 16: 141-147.

133. Pizarro V., Ferrer M., Domingo - Salvany A. et al. The utilization of dental care services acording to health incurance coverage in Catalonia (Spain) // Community Dent Oral Epidemiol, 2009; 37: 78-84.

134. Porter G. Paranasal sinus anatomy and function // Grand Round Presentation, The University of Texas Medical Branch (UTMB). Department of Otolaryngology, 2002.

135. Pramstraller M., Farina R., Franceschetti G. et al. Ridge dimensions of edentulous posterior maxilla: a retrospective analysis of a cohort of 127 patients using computerized tomography data // Clin Oral Impl Res, 2011; 22: 54-61.

136. Quereshy F.A., Savell T.A., Paloma J.M. Applications of cone beam computed tomography in the practice of oral and maxillofacial surgery // J Oral Maxillofac Surg, 2008; 66: 791-796.

137. Quirynen M., Lefever D., Helling P. et al. Transient swelling of the Schneiderian membrane after transversal sinus augmentation: a pilot study // Clin Oral Impl Res, 2012; doi: 10.1111/clr.12056.

138. Rae T.C., Koppe T. Independence of biomechanical forces and craniofacial pneumatization in Cebus // Anat Rec, 2008; 291: 1414-1419. 
139. Raghoebar G.M., Batenburg R.H., Timmenga N.M. et al. Morbidity and complications of bone grafting of the floor of the maxillary sinus for the placement of endosseous implants // Mund Kiefer Gesichtschir, 1999; 3: 65-69.

140. (1) Ramirez - Fernandez M.P., Calvo - Guirado J.L., Delgado - Ruiz R.A. et al. Ultrastructural study by blackscattered electron imaging and elemental microanalysis of biomaterial-to-bone interface and mineral degradation of bovine xenografts in maxillary sinus floor elevation // Clin Oral Impl Res, 2013; 24: 645-651.

141. (2) Ramirez - Fernandez M.P., Calvo - Guirado J.L., Mate - Sanchez del Val J.E. et al. Ultrastructural study by blackscattered electron imaging and elemental microanalysis of bone-to-biomaterial interface and mineral degradation of porcine xenografts used in maxillary sinus floor elevation // Clin Oral Impl Res, 2013; 24: 523-530.

142. Rege I.C., Sousa T.O., Leles C.R. et al. Occurrence of maxillary sinus abnormalities detected by cone beam $\mathrm{CT}$ in asymptomatic patients // BMC Oral Health, 2012; 12: 30-37.

143. Reich K.M., Huber C.D., Lippnig W.R. et al. Atrophy of the residual alveolar ridge following tooth loss in an historical population // Oral Diseases, 2011; 17: $33-44$.

144. Reznick J.B. Options in alveolar ridge preservation grafting // www.dentaltown.com, 2004.

145. Riachi F., Naaman N., Tabarani C. et al. Inluence of material properties on rate of resorption of two bone materials after sinus lift using radiographic assessment // Int J Dent, 2012; doi: 10.1155/2012/737262.

146. Richard M.J., Morris C., Deen B.F. et al. Analysis of anatomic changes of the aging facial skeleton using computer-assisted tomography // Ophthal Plast Reconstr Surg, 2009; 25: 382-386.

147. Ritter L., Lutz J., Neugebauer J. et al. Prevalence of pathologic findings in the maxillary sinus in cone - beam computerized tomography // Oral Surg Oral Med Oral Pathol Oral Radiol Endod, 2011; 111: 634-640.

148. Robb R.A. Dynamic Spatial Reconstructor: An X-ray Video Fluoroscopic CT scanner for dynamic volume imaging of moving orgāns // IEEE Trans Med Im, 1982; 1: 22-23. 
149. Rowntree D. Statistics without tears. An introduction for non-mathematicans // In: Penguin Books, London, New York, Victoria, Ontario, Auckland. 2000: $28-176$.

150. Sahlstrand - Johnson P., Jannert M., Strombeck A. et al. Computed tomography measurements of different dimensions of maxillary and frontal sinuses // BMC Medical Imaging, 2011; 11: 8-15.

151. Salma I., Pilmane M., Skagers A. et al. Early morphofunctional response of contact tissue after intraosal implantation in rabbit jaw of pure synthetic hydroxyapatite (HAp) bioceramic materials and HAp saturated with lidocaine // Stomatologija, 2009; 11: 113-118.

152. Sbordone L., Toti P., Menchini - Fabris G.B. et al. Volume changes of autogenous bone grafts after alveolar ridge augmentation of atrophic maxillae and mandibles // Int J Oral Maxillofac Surg, 2009; 38: 1059-1065.

153. Sbordone C., Toti P., Guidetti F. et al. Volume changes of iliac crest autogenous bone grafts after vertical and horizontal alveolar ridge augmentation of atrophic maxillas and mandibles: a 6 year computerized tomographic followup // J Oral Maxillofac Surg, 2012; 70: 2559-2565.

154. Schlegel K.A., Donath K., Rupprecht S. et al. De novo bone formation using bovine collagen and platelet-rich plazma // Biomaterials, 2004; 25: 5387-5393.

155. Schmitt C.M., Doering H., Schmidt T. et al. Histological results after maxillary sinus augmentation with Straumann BoneCeramic, Bio-Oss, Puros and autologous bone. A randomized controlled clinical trial // Clin Oral Impl Res, 2013; 24: 576-585.

156. Schmitt C., Karasholi T., Lutz R. et al. Long-term changes in graft height after maxillary sinus augmentation, onlay bone grafting and combination of both techniques: a long-term retrospective cohort study // Clin Oral Impl Res, 2012; doi: $10.1111 /$ clr.12045.

157. Schulze R., Heil U., Gro $\beta$ D. et al. Artefacts in CBCT: a review // Dentomaxillofac Radiol, 2011; 40: 264-273.

158. Schulze R.K.W., Berndt D., d'Hoedt B. On cone-beam computed tomography artifacts induced by titanium implants // Clin Oral Impl Res, 2010, 21; 100-107.

159. Schwartz - Arad D., Herzberg R., Dolev E. The prevalance of surgical complications of the sinus graft procedure and their impact on implant survival // J Periodontol, 2004; 75: 511-516. 
160. Shanbhag S., Karnik P., Shirke P. et al. Cone-beam computed tomographic analysis of sinus membrane thickness, ostium patency, and residual ridge height in the posterior maxilla: implications for sinus floor elevation // Clin Oral Impl Res, 2013; doi: 10.1111/clr.12168.

161. Sharan A., Madjar D. Correlation between maxillary sinus floor topography and related root position of posterior teeth using panoramic and cross-sectional computed tomography imaging // Oral Surg Oral Med Oral Pathol Oral Radiol Endod, 2006; 102: 375-381.

162. Sharan A., Madjar D. Maxillary sinus pneumatization following extractions: a radiographic study // Int J Oral Maxillofacial Impl, 2008; 23: 48-56.

163. Shaw R.B., Kahn D.M. Aging of the midface bony elements: a three dimensional computed tomography study // Plast Reconstr Surg, 2007; 119: 675-681.

164. Shen J., Wildman J., Steele J. Measuring and decomposing oral health inequalities in an UK population // Community Dent Oral Epidemiol, 2013; 41: $481-489$.

165. Sinelnikov R.D., Sinelnikov J.R. Atlas anatomii celoveka // In: 2-e izdanija. Medicina, Moskva, 1996: 58-61.

166. Singh A., Rouxel P., Watt R.G. et al. Social inequalities in clustering of oral helath related behaviours in a national sample of British adults // Prev Med, 2013; 57: 102-106.

167. Skagers A., Berzina - Cimdina L., Salms G. et al. An agent for prevention of bone tissue resorption and atrophy after endoprosthetic surgery. LV14171// Espacenet.com, 2010.09.20.

168. Smith K.D., Edwards P.C., Saini T.S. et al. The prevalence of concha bullosa and nasal septal deviation and their relationship to maxillary sinusitis by volumetric tomography // Int J Dent, 2010; doi: 10.1155/2010/404982.

169. Soardi C.M., Spinato S., Zaffe D. et al. Atrophic maxillary floor augmentation by mineralized human bone allograft in sinuses of different size: a histologic and histomorphometric analysis // Clin Oral Impl Res, 2011; 22: 560-566.

170. Soardi C.M., Zaffe D., Motroni A. et al. Quantitative comparison of cone beam computed tomography and microradiography in the evaluation of bone density after a maxillary sinus augmentation: a preliminary study // Clin Implant Dent Relat Res, 2012; doi: 10.1111/cid.12016. 
171. Solar P., Geyerhofer U., Traxler H. et al. Blood supply to the maxillary sinus relevant to sinus floor elevation procedures // Clin Oral Implant Res, 1999; 10: 34-44.

172. Stallman J.S., Lobo J.N., Som P.M. The incidence of concha bullosa and its relationship to nasal septal deviation and paranasal sinus disease // AJNR Am J Neuroradiol, 2004; 25: 1613-1618.

173. Sukovic P. Cone beam computed tomography in dentomaxillofacial imaging // aadmft.com 2004.

174. Summers R.B. Sinuse lift elevation with osteotomes // J Esthet Dent, 1998; 10: $164-171$.

175. Swennen G.R.J., Schutyser F. Three-dimensional cephalometry: spiral multislice vs cone-beam computed tomography // Am J Orthod Dentofacial Orthop, 2006; 130: 410-416.

176. Tadjoedin E.S., De Lange G.L., Bronckers A.L.J.J. et al. Deproteinized cancellous bovine bone (Bio-Oss) as bone substitute for sinus floor elevation. A retrospective, histomorphometrical study of five cases // J Clin Periodontol, 2003; 30: 261-270.

177. Tapety F.I., Amizuka N., Uoshima K. et al. A histological evaluation of the involvement of Bio-Oss in osteoblastic differentiation and matrix synthesis // Clin Oral Impl Res, 2004; 15: 315-324.

178. Temmerman A., Hertele S., Teughels W. et al. Are panoramic images reliable in planning sinus augmentation procedures? // Clin Oral Impl Res 2011; 22: 189-194.

179. Tetsch J., Tetsch P., Lysek D.A. Long-term results after lateral and osteotome technique sinus floor elevation: a retrospective analysis of 2190 implants over a time period of 15 years // Clin Oral Impl Res, 2010; 21: 497-503.

180. Tezer M.S., Tahamiler R., Canakcioglu S. Computed tomography findings in chronic rhinosinusitis patients with and without astma // Asian Pac J Allergy Immunol, 2006; 24: 123-127.

181. Thilander B., Ronningen O. Craniofacial development and growth. Introduction to orthodontics // Tandlakarforlaget, Stokholma, 1985: 13-42.

182. Thomas M., Yawn B., Price D. et al. EPOS primary care guidlines: European position paper on the primary care diagnosis and management of rhinosinusitis and nasal polyps 2007-a summary // Prim Care Resp J, 2008; 17: 79-89. 
183. Timmenga N.M., Raghoebar G.M., Liem R.S.B. et al. Effects of maxillary sinus floor elevation surgery on maxillary sinus physiology // Eur J Oral Sci, 2003; 111: 189-197.

184. Tosta M., Cortes A.R., Correa L. et al.. Histological and histomorphometric evaluation of synthetic bone substitute for maxillary sinus grafting in humans // Clin Oral Impl Res, 2013; 24: 866-870.

185. Trisi P., Massei G. Biologic and biomechanical basis of bone healing and osteointegration of implants in sinus grafts // In: Testori T, Del Fabro M., Weinstein R., Wallace S. Maxillary sinus surgery and alternatives in treatment, Quintessence Publishing, London, Berlin, Chicago, 2009; 59-79.

186. Tsai T.L., Lan M.Y., Ho C.Y. There is no structural relationship between nasal septal deviation, concha bullosa and paranasal sinus fungus balls // Scient World J, 2012; doi: 10.1100/2012/181246.

187. Tseveenjav B., Suominen A.L, Vehkalahti M.M. Oral health - related behaviours among dentante adults in Finland: findings from the Finnish Health 2000 Survey // Eur J Oral Sci, 2012; 120: 54-60.

188. Umanjec - Korac S., Wu G., Hassan B. et al. A retrospective analysis of the resorption rate of deproteinized bovine bone as maxillary sinus graft material on cone beam computed tomography // Clin Oral Impl Res, 2013; doi: $10.1111 /$ clr.12174.

189. United States Patent and Trademark Agency. Sinus lift method // patft.uspto.gov 1998; US005711315A.

190. Vallo J., Taipale L.S., Huumonen S. et al. Prevalance of mucosal abnormalities of the maxillary sinus and their relationship to dental disease in panoramic radiography: results from the Health 2000 Health Examination Survey // Oral Surg Oral Med Oral Pathol Oral Radiol Endod, 2010,109: 80-87.

191. Van den Bergh J.P.A, ten Bruggenkate C.M., Disch F.J.M, Tuinzing D.B. Anatomical aspects of sinus floor elevations // Clin Oral Impl Res, 2000; 11: 256-265.

192. Vannier M.W. Craniofacial computed tomography scanning: technology, applications and future trends // Orthod Craniofac Res, 2003; 6: 23-30.

193. Van Zyl A.W., Van Heerden W.F.P. A retrospective analysis of maxillary sinus septa on reformatted computerized tomography scans // Clin Oral Impl Res, 2009; 20: 1398-1401. 
194. Vidya C.S., Shamasundar N.M., Manjunatha B. et al. Evaluation of size and volume of maxillary sinus to determine gender by 3D computerized tomography scan method using dry sculls of south Indian origin // Int J Cur Res Rev, 2013; 5: 97-100.

195. Vidzis A., Cema I., Brinkmane A. et al. Quantity and quality analysis of dental prosthodontics among retirement age residents from nursing homes in different regions of Latvia and retirement age patients from dental clinic in Riga // Stomatologija, 2012; 14: 23-27.

196. Vidzis A., Cema I., Krasta I. et al. Evaluation of oral health status of retirement - age population in Latvia // Stomatologija, 2011; 13: 68-72.

197. Wagner W., Wiltfang J., Pistner H. et al. Bone formation with a biophasic calcium phosphate combined with fibrin sealant in maxillary sinus floor elevation for delayed dental implant // Clin Oral Impl Res, 2012; 23: $1112-1117$.

198. Whaites E. Essentials of dental radiography and radiology // In: 3rd edition. Churchill Livingstone, London, 2002; 75-161.

199. White S.C., Pharoah M.J. Oral radiology. Principles and interpretation // In: 6th edition. Mosby Elsevier, Missuri, 2009: 109-207.

200. Wikipedia.org. Cone beam computed tomography. 2013. 03. 25.

201. Yoshiura K., Ban S., Hijiya T. et al. Analysis of maxillary sinusitis using computed tomography // Dentomaxillofac Radiol, 1993; 22: 86-92.

202. Zijderveld S.A., Van den Bergh J.P.A., Schulten E.A.J.M. et al. Anatomical and surgical findings and complications in 100 consecutive maxillary sinus floor elevation procedures // J Oral Maxillofac Surg, 2008; 66: 1426-1438.

203. Zimmermman G., Moghaddam A. Allograft bone matrix versus synthetic bone graft substitutes // J Injury, 2011; 42: 16-21.

204. Zhang Y., Tangl S., Huber C.D. Effects of Choukroun's platelet - rich fibrin on bone regeneration in combination with deproteinized bovine bone mineral in maxillary sinus augmentation: A histological and histomorphometric study // J Craniomaxillofac Surg, 2012; 40: 321-328. 


\section{PUBLIKĀCIJAS UN ZIŅOJUMI PAR PĒTĪJUMA TĒMU}

\subsection{Publikācijas par pētījuma tēmu}

1. Neimane L., Skaǵers A., Slaidiņa A. Evaluation of atrophic edentulous maxillary alveolar bone with cone beam computed tomography (CBCT) in postmenopausal women // In: International symposium on biomedical engineering and medical physics, IFMBE Proceeding 2013; 38:63-65.

2. Neimane L., Skagers A., Salms G. et al. Radiodensitometric analysis of maxillary sinus-lift areas enforced with bone substitute materials containing calcium phosphate // Acta Chirurgica Latviensis, 2012; 12: 41-44.

3. Neimane L., Skaǵers A., Slaidiņa A. Atrofiska augšžokḷa alveolārā kaula blīvuma izvērtēšana ar konusa stara datortomogrāfiju pacientēm pēc menopauzes vecumā // RSU Zinātniskie raksti, 2012; 1. sējums: 261-264.

4. Neimane L., Skagers A. Pre- and postoperative long-term assessment of sinus floor augmentation site using cone beam computed tomography // Acta Chirurgica Latviensis, $2013 ; 13: 33-36$.

\subsection{Konferenču tēzes par pētījuma tēmu}

1. Ģ. Šalms, L. Neimane, A. Skağers, G. Ž̄̄gurs. Koniska stara datortomogrāfija augšžokḷa dobuma pamatnes paaugstināšanas un zobu implantācijas vēlīno rezultātu izvērtēšanā // RSU Zinātniskās konference, 298. lpp. 2010. gads. Tēzes.

2. Ģ. Šalms, I. Šalma, M. Pilmane, L. Neimane. Kaula kvalitātes novērtēšana pirms augšžokḷa dobuma paaugstināšanas operācijām ar imūnhistologijas metodi // RSU Zinātniskā konference, 326. 1pp. 2011. gads. Tēzes.

3. L. Neimane, Ģ.Šalms, A.Skaǵers. Atrofiska augšžokļa pastiprināšana ar kaulaudus aizvietojošiem materiāliem zobu implantācijas pacientiem - densitometriska analīze // RSU Zinātniskā konference, 329. 1pp. 2011.gads. Tēzes. 
4. A. Skagers, I. Salma, M. Pilmane, G. Salms, L. Feldmane, L. Neimane, L. Berzina Cimdina. Triple confirmation for bioactivity of synthetic hydroxyapatite in bony environment // V European chapter of the tissue engeneering and regenerative medicine international society (TERMIS), 5.15. lpp. Granāda, Spānija. Tēzes.

5. L. Neimane, G. Salms, A. Skagers. Densitometric analysis of atrophic maxilla enforced with biomaterials // Nordic Young Scientist Conference in Dentistry 2011, 35. lpp. Helsingora, Dānija. Tēzes.

6. Ģ. Šalms, I. Šalma, M. Pilmane, A. Skaǵers, J. Ločs, L. Bērziņa - Cimdiṇa, L. Neimane. Imūnohistoķīmijas un koniskā stara datortomogrāfijas metožu izmantojums kaula kvalitātes novērtēšanā pirms un pēc augšžokḷa dobuma paaugstināšanas operācijās // LU Pasaules latviešu zinātnieku kongresa „Medicīnas zinātne un Latvijas sabiedrības veselība XXI gadsimtā”, 97. lpp. 2011. gads. Tēzes.

7. L. Neimane, Ģ. Šalms, A. Skaǵers. Densitometriskā analīze atrofiskam augšžoklim, kas pastiprināts ar kaulaudus aizvietojošiem materiāliem zobu implantācijas gadījumos // LU Pasaules latviešu zinātnieku kongresa „Medicīnas zinātne un Latvijas sabiedrības veselība XXI gadsimtā”, 62. lpp. 2011. gads. Tēzes

8. A. Skag̊ers, Ģ. Šalms, L. Neimane, M. Pilmane, L. Bērziņa - Cimdina, I. Šalma, L. Feldmane. Trīskāršs apstiprinājums sintētiskā hidroksiapatīta (HAp) keramikas implantātu bioaktivitātei kaulaudu vidē // RSU Zinātniskā konference, 321. 1pp. 2012. gada. Tēzes.

9. L. Neimane, A. Skaǵers. Atrofiska augšžokḷa alveolārā kaula kvalitatīivie un kvantitatīvie rādītāji sievietēm ar normālu kaula masu, osteopēniju un osteoporozi // RSU Zinātniskā konference, 302. lpp. 2012. gada. Tēzes.

10. L. Neimane. A. Skaǵers. Ģ. Šalms. Augšžokḷa kaula densitometriskie mērījumi, pēc sīnusa grīdas paaugstināšanas operācijas un zobu implantātu ievietošanas // 16. Starptautiskā sejas - žokḷu un stomatologu konference. Jaunās tehnolog̣ijas stomatologiijā. 126. lpp. 2012. gads. Pēterburga, Krievija. Tēzes.

11. L. Neimane, A. Skagers, A. Slaidina. Maxillary bone in female with normal, osteopenic and osteoporotic bone // Eiropas Mutes, sejas un žokḷu radiologu kongress, 45. lpp. 2012. Leipciga, Vācija. Tēzes

12. L. Neimane, A. Skaǵers. Evaluation of sinus - lift enforced with biomaterials by cone beam computed tomography // Bioceramics and cells for reinforcment of bone. 24 . lpp. 2012. gads. Riga, Latvia. 
13. L. Neimane, A. Skaǵers. Preoperative and postoperative evaluation of sinus-lift with cone beam computed tomography // 8. Congress of Baltic association for maxillofacial and plastic surgery. 12. lpp. 2013. gads. Kauņa, Lietuva. Tēzes.

14. L. Neimane, A. Skagers. Pre and postoperative evaluation of maxillary sinus by CBCT // 19. Starptautiskā Mutes un sejas-žokļu radiologu kongress, 78. lpp. 2013. gads. Bergena, Norvēgija. Tēzes.

15. L. Neimane, A. Skaǵers. Augšžokḷa dobuma pamatnes paaugstināšanas biomateriāla/ audu hibrīda radiodensitātes izmaiņas laikā // RSU Zinātniskā konference, 315. lpp, 2014. gads. Tēzes.

\subsection{Ziņojumi kongresos un konferencēs}

1. Ģ. Šalms, L. Neimane, A. Skağers, G. Ž̄̄gurs. Koniska stara datortomogrāfija augšžokļa dobuma pamatnes paaugstināšanas un zobu implantācijas vēlīno rezultātu izvērtēšanā // RSU Zinātniskās konference, 2010. gads.

2. G. Šalms, I. Šalma, M. Pilmane, L. Neimane. Kaula kvalitātes novērtēšana pirms augšžokḷa dobuma paaugstināšanas operācijām ar imūnhistolog̣ijas metodi // RSU Zinātniskā konference, 2011.gads.

3. L. Neimane, Ģ. Šalms, A. Skaǵers. Atrofiska augšžokḷa pastiprināšana ar kaulaudus aizvietojošiem materiāliem zobu implantācijas pacientiem - densitometriska analīze // RSU Zinātniskā konference, 2011.gads.

4. A. Skagers, I. Salma, M. Pilmane, G. Salms, L. Feldmane, L. Neimane, L. Berzina Cimdina. Triple confirmation for bioactivity of synthetic hydroxyapatite in bony environment // V European chapter of the tissue engeneering and regenerative medicine international society (TERMIS). 2011. Granāda, Spānija.

5. L. Neimane, G. Salms, A. Skagers. Densitometric analysis of atrophic maxilla enforced with biomaterials // Nordic Young Scientist Conference in Dentistry, 2011. Helsingora, Dānija.

6. Ģ. Šalms, I. Šalma, M. Pilmane, A. Skaǵers, J. Ločs, L. Bērziņa - Cimdiṇa, L. Neimane. Imūnohistoķīmijas un koniskā stara datortomogrāfijas metožu izmantojums kaula kvalitātes novērtēšanā pirms un pēc augšžokḷa dobuma paaugstināšanas operācijās // LU Pasaules latviešu zinātnieku kongresa „Medicīnas zinātne un Latvijas sabiedrības veselība XXI gadsimtā”. 2011. gads. 
7. L. Neimane, Ģ. Šalms, A. Skaǵers. Densitometriskā analīze atrofiskam augšžoklim, kas pastiprināts ar kaulaudus aizvietojošiem materiāliem zobu implantācijas gadījumos // LU Pasaules latviešu zinātnieku kongresa „Medicīnas zinātne un Latvijas sabiedrības veselība XXI gadsimtā”. 2011. gads.

8. A. Skag̣ers, Ģ. Šalms, L. Neimane, M. Pilmane, L. Bērziņa - Cimdina, I. Šalma, L. Feldmane. Trīskāršs apstiprinājums sintētiskā hidroksiapatīta (HAp) keramikas implantātu bioaktivitātei kaulaudu vidē // RSU Zinātniskā konference, 2012. gads.

9. L. Neimane, A. Skaǵers. Atrofiska augšžokḷa alveolārā kaula kvalitatīvie un kvantitatīvie rādītāji sievietēm ar normālu kaula masu, osteopēniju un osteoporozi // RSU Zinātniskā konference, 2012. gads.

10. L. Neimane. A. Skaǵers. Ģ. Šalms. Augšžokḷa kaula densitometriskie mērījumi, pēc sīnusa grīdas paaugstināšanas operācijas un zobu implantātu ievietošanas // 16. Starptautiskā sejas - žokḷu un stomatologu konference. Jaunās tehnologijas stomatologiijā. 2012. Pēterburga, Krievija.

11. L. Neimane, A. Skagers, A. Slaidina. Maxillary bone in female with normal, osteopenic and osteoporotic bone // Eiropas Mutes, sejas un žokḷu radiologu kongress, 2012. Leipciga, Vācija.

12. L. Neimane, A. Skaǵers. Evaluation of sinus - lift enforced with biomaterials by cone beam computed tomography // Bioceramics and cells for reinforcment of bone. 2012. Rīga, Latvija.

13. L. Neimane, A. Skaǵers. Preoperative and postoperative evaluation of sinus-lift with cone beam computed tomography // 8. Congress of Baltic association for maxillofacial and plastic surgery 2013. gads. Kauņa, Lietuva.

14. L. Neimane, A. Skagers. Pre and postoperative evaluation of maxillary sinus by CBCT // 19. Starptautiskā Mutes un sejas - žokļu radiologu kongress, 2013. Bergena, Norvēgija.

15. L. Neimane, A. Skaǵers. Augšžokḷa dobuma pamatnes paaugstināšanas biomateriāla/ audu hibrīda radiodensitātes izmaiņas laikā // RSU Zinātniskā konference, 2014. gads. 


\section{PIELIKUMI}

\subsection{Uzaicinājuma vēstule pacientiem atkārtotam KSDT izmeklējumam}

Labdien .kungs/ kundze,

Jums 20XX. gadā RSU Stomatolog̣ijas institūtā tika veikta zobu implantācijas/ augšžokḷu dobumu paaugstināšanas operācija. Sakarā ar augšžokḷa kaula nepietiekošiem izmēriem kauls tika pastiprināts ar kaulaudus aizvietojošiem materiāliem. Svarīgi ir ilgākā laika periodā sekot žokḷa kaula un implantātu stāvoklim, jo savlaicīgi neatklāta kaulaudu uzsūkšanās var novest pie zobu implantātu un uz tiem balstītu zobu protēžu zaudējuma. Stomatologijas institūtā darbojas moderna 3 dimensiju datora tomogrāfijas iekārta, kas no citām atšķiras ar lielāku informāciju un mazāku staru slodzi. Iesakām Jums uz kaula pastiprināšanas un zobu implantācijas vēlīnu rezultātu novērtēšanu griezties Stomatologijas institūtā, kur Jums bez maksas veiks klīnisku izmeklējumu un 3-dimensiju datora tomogrāfiju ar ieteikumiem par tālāku režīmu implantātu dzīvildzes uzturēšanai.

Klīniskos izmeklējumus pie Jūs operējošā ķirurga varat veikt trešdienās no plkst. $9.00 \mathrm{lī} d z$ 15.00, iepriekš pierakstoties pa telefonu 67455523, pie Ķirurǵijas klīnikas administratores.

Bezmaksas 3 dimensiju datora tomogrāfijas izmeklējumu varat veikt jebkurā sev izdevīgā laikā 201.kabinetā (2.stāvā) - darba dienās 8-20, sestdienās 9-15. Tālrunis uzzin̄ām 67454359.

Ar cieņu,

Prof. A. Skaǵers

Mutes, sejas un žokḷu

Ķirurgijijas klīnikas vadītājs
Dr. L. Neimane

Mutes, sejas un žokḷu

Diagnostiskās radiolog̣ijas

nodaļas vadītāja 


\title{
12.2. RSU Ētikas komitejas lēmums
}

Veidlapa Nr E-9 (2)

\author{
RSU ẼTIKAS KOMITEJAS LEMUMS
}

Rīga, Dzirciema iela 16, LV-1007 Tel.67409137

\begin{tabular}{lll}
\hline Komitejas sastāvs & Kvalifikācija & Nodarbošanās \\
\hline 1. Asoc. prof. Olafs Brūvers & Dr.miss. & teologs \\
2. Profesore Vija S̄̃le & Dr.phil. & filozofs \\
3. Docente Santa Purviña & Dr.med. & farmakologs \\
4. Asoc. prof. Voldemārs Arnis & Dr.biol. & rehabilitologs \\
5. Profesore Regīna Kleina & Dr.med. & patanatoms \\
6. Asoc. prof. Egils Korṇevs & Dr.habil.med. & stomatologs \\
7. Asoc. prof. Guntars Pupelis & Dr.med. & ķirurgs \\
\hline
\end{tabular}

Pieteikuma iesniedzējs: Laura Neimane

RSU Doktorantūras nodaja

Pētījuma nosaukums: Augšžokla alveolārā izauguma izmēri un struktūra zobu implantoloǵijā

Iesniegšanas datums: 15.12 .2010$.

Pētījuma protokols:

(X) Pētījuma veids: kvantitatīvs pētījums

(X) Pētījuma populācija: 100 pacienti

(X) Informācija par pētījumu:

(X) Piekrišana dalībai pētījumā:

Citi dokumenti:

1. Anketa

2. Iestādes vadītāja ațauja veikt pētījumu

Lēmums: piekrist biomedicīniskajam pētījumam

Komitejas priekšsēdētājs Olafş Brūvers Tiłuls: Dr.miss,, asoc.prof.

Êtikas komitejas sēdes datums: 16.12 .2010 . 